UNIVERDIDADE DE SÃO PAULO

FACULDADE DE EDUCAÇÃO

MÁRCIA FERNANDES LOURENÇO

\title{
Materiais educativos em museus e sua contribuição para a alfabetização científica
}

SÃO PAULO 
MÁRCIA FERNANDES LOURENÇO

\section{Materiais educativos em museus e sua contribuição para a alfabetização científica}

Tese apresentada à Faculdade de Educação da Universidade de São Paulo para a obtenção do título de Doutora em Educação.

Área de concentração: Ensino de Ciências e Matemática.

Orientadora: Profa. Dra. Martha Marandino.

São Paulo 
AUTORIZO A REPRODUÇÃO E DIVULGAÇÃO TOTAL OU PARCIAL DESTE TRABALHO, POR QUALQUER MEIO CONVENCIONAL OU ELETRÔNICO, PARA FINS DE ESTUDO E PESQUISA, DESDE QUE CITADA A FONTE.

Catalogação na Publicação

Serviço de Biblioteca e Documentação

Faculdade de Educação da Universidade de São Paulo

371.389 Lourenço, Márcia Fernandes

L892m Materiais educativos em museus e sua contribuição para a alfabetização científica / Márcia Fernandes Lourenço; orientação Martha Marandino. São Paulo: s.n., 2017.

$292 \mathrm{p}$.

Tese (Doutorado - Programa de Pós-Graduação em Educação. Área de Concentração: Ensino de Ciências e Matemática) - - Faculdade de Educação da Universidade de São Paulo.

1. Museus 2. Materiais educativos 3. Educação em museus I. Marandino, Martha, orient. 
LOURENÇO, M. F. Materiais educativos em museus e sua contribuição para a alfabetização científica. Tese apresentada à Faculdade de Educação da Universidade de São Paulo para a obtenção do título de Doutora em Educação.

Aprovada em:

Banca Examinadora:

Prof. Dr.

Instituição:

Julgamento:

Assinatura:

Prof. Dr.

Instituição:

Julgamento:

Assinatura:

Prof. Dr. Instituição:

Julgamento:

Assinatura:

Prof. Dr. Instituição:

Julgamento:

Assinatura:

Prof. Dr. Instituição:

Julgamento: Assinatura: 
Aos meus pais Elza Fernandes Lourenço e José Madeira Lourenço (in memoriam) pelo apoio incondicional. 


\section{AGRADECIMENTOS}

À Profa. Martha Marandino pela orientação paciente, participativa e competente sempre e pela amizade carinhosa e instigante.

Ao Museu de Zoologia da USP em especial à Diretoria Geral e à Chefia da Divisão de Difusão Cultural, pela autorização e apoio para a realização deste trabalho.

Ao Parque Zoológico Municipal Quinzinho de Barros pela autorização para a realização deste trabalho em suas dependências.

À Peônia Brito de Moraes Pereira, Roberta Araújo Ibanez e Viviane Aparecida Rachid Garcia pelas entrevistas, bate papos, pela recepção sempre muito afetuosa e cuidadosa e auxílio no acesso aos materiais educativos do Zôo de Sorocaba.

Aos amigos do MZUSP Felipe Elias, Rosângela Cavalcante, Vanessa Sakai e Roseli Retamero com os quais pude sempre contar nos momentos difíceis durante a confecção deste trabalho.

À Ana Maria Vasques, Jaqueline Battilana, Omair Guilherme Tizzot Filho e Maria Aparecida Giamusso pelos almoços regados à discussões e reflexões sobre o sentido da vida!

Agradecimento especial para a Graziele Scalfi e Jéssica Norberto pelo auxílio na validação dos dados deste trabalho.

Aos colegas do GEENF: Tania, Eliane, Cynthia, Adriano, Adriana, JulianaS, Fausto, Leonardo, Fernanda, Bárbara, Amanda, Ana Senac, Carla... e tantos outros que passaram por este grupo maravilhoso durante os anos que faço parte dele.

Às amigas Djana Contier Fares, Maria Paula Correia de Araújo e Luciana Conrado Martins pelos ótimos papos, desabafos e parcerias.

Aos meus companheiros peludos Dudu, Yasmim e Lilica incondicionalmente prontos a demonstrar amor e alegria quando as coisas não andam como a gente quer.

À minha família, de coração, pelo apoio, compreensão e auxílio sempre. 
Ao meu marido Marcos Antonio Ferraz, por vivermos a nossa vida juntos, por dividirmos os momentos ótimos e não tão ótimos assim, pelo auxílio nas revisões e opiniões neste trabalho, pelas minhas ausências enfim, pelo amor sem fim. 


\section{RESUMO}

LOURENÇO, M. F. Materiais educativos em museus e sua contribuição para a alfabetização científica. 2017. 292 f. Tese (Doutorado) - Faculdade de Educação, Universidade de São Paulo, São Paulo, 2017.

As discussões atuais sobre alfabetização científica indicam um consenso de que ela é um processo que ocorre por toda a vida do indivíduo em vários espaços de educação. Os museus cumprem um importante papel na educação dos indivíduos fora do ambiente escolar e ao longo da vida. Estas instituições oferecem uma série de atividades educativas com a intenção de aproximar e melhorar a percepção pública sobre ciência. Dentre estas atividades, está a produção e utilização de materiais educativos. O objetivo geral desta pesquisa é: investigar como/se os materiais utilizados nas diversas ações educacionais e culturais realizadas pelos museus contribuem para o processo de alfabetização científica do público. O trabalho foi realizado no Parque Zoológico Municipal Quinzinho de Barros, Sorocaba, SP analisando 27 materiais produzidos pela instituição e a interação de um deles com o público escolar visitante. Os materiais consistem em objetos tridimensionais (animais e plantas conservadas, modelos e réplicas). Para a coleta e análise dos dados utilizamos metodologia qualitativa e quantitativa com diversos procedimentos que nos permitiram triangular os dados para conferir maior credibilidade à pesquisa. Para a análise dos dados utilizamos a ferramenta teórico-metodológica desenvolvida por Cerati (2014), Rocha (2016) e Oliveira (2016), que propuseram indicadores e atributos para avaliar processos e produtos desenvolvidos em museus. Os resultados revelaram que, sob o ponto de vista da intenção da produção dos materiais educativos, eles contribuem para a alfabetização científica com a identificação de todos os indicadores (científico, interface social, institucional e estético/afetivo/cognitivo), assim como 11 dos 16 atributos de alfabetização científica. A interação do público com 1 dos materiais (mochila de curiosidades) mostrou a presença de 2 indicadores e 4 atributos. Concluímos que os materiais contribuem para a alfabetização científica do público, mas que estes poderiam incluir a abordagem de aspectos relacionados com a relevância da instituição, do pesquisador e da própria ciência, atributos pouco identificados durante a análise.

Palavras-chave: alfabetização científica, museus, zoológicos, educação em museus, materiais educativos. 


\section{ABSTRACT \\ LOURENÇO, M. F. Educative materials in museums and their contribution for}

Scientific literacy. 2017. 292 f. Thesis (PhD in Education) - Education Faculty, São Paulo University, São Paulo, 2017.

Current discussions about scientific literacy have shown a consensus that this is a continuous process that occurs during individuals lifetime, in different education facilities. Museums play an important role in education out of school environment and along life. Such institutions provide a number of educative activities aiming to approach and to improve awareness about science. Among them is the production and use of educational materials. The general objective of this research is to investigate how/if these materials used in the various museums educational and cultural actions contribute to the process of public scientific literacy. This research was conducted in Parque Zoológico Municipal Quinzinho de Barros, located in the city of Sorocaba, São Paulo state. Twentyseven materials produced by this institution were analyzed, particularly the interaction between one of these materials and the visiting students audience. These materials consisted of tridimensional objects - specimens of preserved animals and plants, models and casts. For data collection and analysis we used quantitative and qualitative methodology, combining different procedures for data triangulation. We used a theoretical-methodological instrument developed by Cerati (2014), Rocha (2016), and Oliveira (2016), who proposed indicators and attributes to evaluate processes and products developed by museums. Our results have shown that, considering the intention of educative materials producing, they contribute for scientific literacy, considering the recognition of all indicators (scientific, social interface, institutional, and aesthetic/affective/cognitive), as weel as 11 of the 16 attributes of scientific literacy. The interaction between the audience with one of the materials (named "curiosities bag") has showed the presence of 2 indicators and 4 attributes. Our conclusion is that these materials contribute for the audience scientific literacy, but on aspects like institution, researcher and science relevance - which appear very discreetly in the analysis - could receive more attention during their development.

Keywords: scientific literacy, museums, zoos, museum education, educational materials. 


\section{LISTA DE FIGURAS}

Figura 1: Parque Municipal Quinzinho de Barros (Zôo de Sorocaba), Sorocaba, SP ................................................

Figuras 2a e 2b: Objetos presentes na "mochila de curiosidades" no momento atual............................................92 e 93

Figura 3: Objetos constituintes do kit Praia Arenosa...............101

Figura 4: Objetos constituintes do kit Costão Rochoso....................102

Figura 5: Objetos constituintes do kit Água doce/rios....................103

Figura 6: Objetos constituintes do kit Cerrado................................105

Figura 7: Objetos constituintes do kit Ecossistemas brasileiros.......106

Figura 8: Objetos constituintes do kit Peixes do Rio Sorocaba........107

Figura 9: Objetos constituintes do kit Artrópodes...........................108

Figura 10: Objetos constituintes do kit Aves I................................109

Figura 11: Objetos constituintes do kit Aves II...............................110

Figura 12: Objetos constituintes do kit Anfíbio.............................111

Figura 13: Objetos constituintes do kit Dinossauros.......................112

Figura 14: Objetos constituintes do kit Mamíferos I.......................113

Figura 15: Objetos constituintes do kit Mamíferos II.......................114

Figura 16: Objetos constituintes do kit Répteis I.............................115

Figura 17: Objetos constituintes do kit Répteis II..........................116

Figura 18: Objetos constituintes do kit Animais Peçonhentos..........117

Figura 19: Objetos constituintes do kit Defesa................................118

Figura 20: Objetos constituintes do kit Alimentação........................119

Figura 21: Objetos constituintes do kit Locomoção..........................120

Figura 22: Objetos constituintes do kit Reprodução.........................121

Figura 23: Objetos constituintes do kit Parasitose Humana...............122 
Figura 24: Objetos constituintes do kit Lixo I

Figura 25: Objetos constituintes do kit Lixo II

Figura 26: Objetos constituintes do kit Botânica I - interação animalplanta...... 126

Figura 27: Objetos constituintes do kit índios I. .127

Figura 28: Objetos constituintes do kit índios II

128

Figura 29: Gráfico da ocorrência dos indicadores de AC nos materiais educativos do Zôo de Sorocaba .144

Figura 30: Gráfico da ocorrência dos atributos de AC nos materiais educativos do Zôo de Sorocaba .145

Figura 31: Interação dos alunos com o bico do tucano e muda de cascavel, objetos da "mochila de curiosidades". .150

Figura 32: Interação dos alunos com o crânio de tamanduá, objeto da "mochila de curiosidades". 154

Figura 33: Interação com o crânio da onça pintada. Crianças comparando os dentes caninos do animal com os próprios dentes....156

Figura 34: Pata de ema durante interação dos objetos da mochila com as crianças 158

Figura 35: Gráfico das ocorrências dos indicadores de AC durante a interação dos estudantes com a "mochila de curiosidades" do Zôo de Sorocaba 159

Figura 36: Gráfico das ocorrências dos atributos de AC durante a interação dos estudantes com o material "mochila de curiosidades" do Zôo de Sorocaba 160

Figura 37: Gráfico comparando os resultados da análise dos indicadores presentes nos materiais educativos realizada por nós e a validação por duas pesquisadoras do GEENF 163

Figura 38: Gráfico comparando os resultados da análise dos atributos presentes nos materiais educativos realizada por nós e a validação por duas pesquisadoras do GEENF 166 


\section{LISTA DE TABELAS}

Tabela 1: Comparação entre a análise dos indicadores presentes nos materiais feita por nós e pelas pesquisadoras do GEENF.. .161

Tabela 2: Comparação entre a análise dos atributos presentes nos materiais feita por nós e pelas pesquisadoras do GEENF..................164 


\section{LISTA DE QUADROS}

Quadro 1: Descrição e análise dos materiais educativos do Zôo de Sorocaba

Quadro 2: Síntese da ocorrência de indicadores e atributos nos materiais educativos do Zôo de Sorocaba. .146

Quadro 3: Análise da interação dos alunos com o material educativo "Mochila de curiosidades" durante visita mediada ao Zôo de Sorocaba. 270

Quadro 4: Síntese da ocorrência de indicadores e atributos comparando o material educativo "mochila de curiosidades" a partir de nossa análise com as interações dos alunos. .161 


\section{SUMÁRIO}

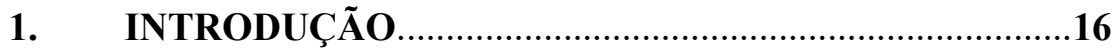

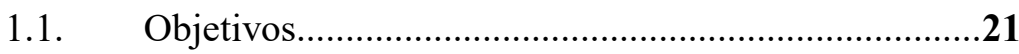

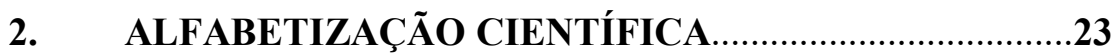

2.1. Contextualização histórica e percursos do conceito de alfabetização científica...................................................................24

2.2. Alfabetização científica em museus................................35

\section{EDUCAÇÃO EM MUSEUS E MATERIAIS}

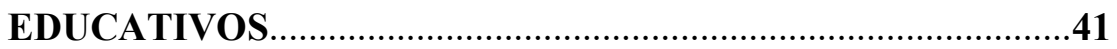

3.1. Aspectos da trajetória da educação nos museus............42

3.2. Particularidades da educação nos museus.......................45

3.3. Materiais educativos em museus.....................................49

3.3.1. Materiais educativos: caracterização e uso pelos museus...................................................................49

3.3.2. Os objetos biológicos como materiais educativos em museus e zoológicos........................................................54

3.3.3. Estudos sobre o potencial de materiais educativos em museus.....................................................................

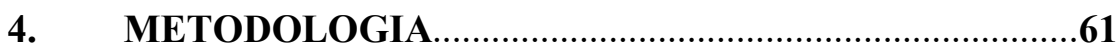

4.1. Coleta de dados.........................................................65

4.1.1. Instrumentos e procedimentos de coleta de dados.........65

4.1.1.1. Concepção, produção e gestão dos materiais educativos....................................................................65

a. Entrevista semiestruturada ……………………….......65

b. Observação.................................................................67

c. . Pesquisa documental..................................................68 
4.1.1.2. Interação do público escolar com os materiais educativos. 69

a. Mochila de curiosidades 69

4.2. Sujeitos da pesquisa. 70

4.3. Caracterização do local de estudo: o Parque Zoológico Municipal Quinzinho de Barros 70

4.4. Atividades educativas do Parque Zoológico Municipal

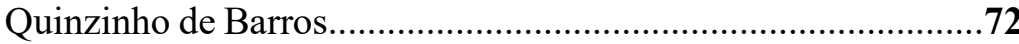

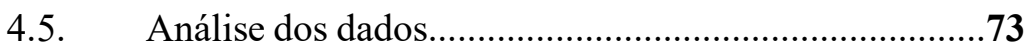

4.5.1. Concepção, produção e gestão dos materiais

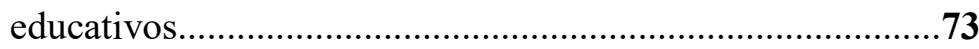

4.5.2. Interação do público com os materiais educativos........74

4.6. Critérios de validação e procedimentos de credibilidade dos dados. .75

4.7. Ferramenta de análise dos dados: indicadores e atributos de alfabetização científica. 75

4.7.1. Indicadores e atributos para análise do processo de Alfabetização Científica......................................................76

1. Indicador Científico..................................76

2. Indicador Interface social...........................79

3. Indicador Institucional.................................84

4. Indicador estético/afetivo/cognitivo.............85

5. ANÁLISE DOS RESULTADOS ......................................88

5.1. Concepção, produção, gestão dos materiais educativos......89

5.1.1. As intenções e os usos dos materiais educativos no Zôo de Sorocaba: contextualizando o objeto de estudo.................89

5.1.1.1. A mochila de curiosidades e a visita orientada....91

5.1.1.2. Os kits ecológicos.............................................98 
5.1.2. Análise qualitativa e quantitativa dos materiais educativos na perspectiva da AC.

5.2. Interação do público com o material educativo "mochila de curiosidades"

146

5.3. Critérios de validação e procedimentos de credibilidade dos dados.

162

6. DISCUSSÃO

6.1. Concepção, produção e gestão dos materiais educativos. 167

6.2. Interação do público com os materiais educativos

.177

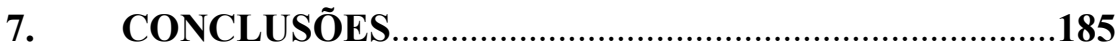

REFERÊNCIAS BIBLIOGRÁFICAS....................................190

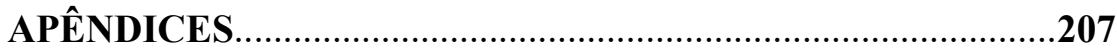

ANEXOS 
1. INTRODUÇÃO 
$\mathrm{O}$ advento das novas tecnologias e da ciência faz com que exista a necessidade de assimilarmos essas novas informações para uma melhor compreensão do impacto da ciência na vida de cada um de nós. Sabemos hoje que as pessoas aprendem constantemente, em todos os dias de sua vida, dentro e fora da escola.

As formas e conteúdos do aprendizado mudaram, já que, além da escola, são muitas as oportunidades de acesso às informações por meio de museus, aquários, jardins zoológicos, áreas naturais e reservas, TV, revistas, cinema, internet, livros etc. Todos esses espaços vêm desempenhando um papel relevante na formação do cidadão e, além de sua importância na aquisição de conhecimentos científicos e ampliação da cultura científica, eles possuem inegável papel comunicacional e educativo.

Nessa pesquisa nosso foco são os museus. Consideramos museus conforme preconizado pelos órgãos oficiais do campo cultural, que os definem como instituições permanentes sem fins lucrativos, abertas ao público que conservam, investigam, comunicam, interpretam e expõem, para fins de preservação, estudo, pesquisa, educação, contemplação e turismo, conjuntos e coleções de valor histórico, artístico, científico, técnico ou de qualquer outra natureza cultural, abertas ao público, a serviço da sociedade e de seu desenvolvimento (IBRAM, 2015; ICOM, 2009). A partir desta definição, adotamos neste trabalho os Jardins Zoológicos como instituições museológicas.

Os museus são considerados locais fundamentais para a divulgação e educação científica, e também promovem momentos de deleite, vivências lúdicas e contemplação. Além disso, no que se refere aos museus de temática biológica, possibilitam o desenvolvimento de competências nos campos da identificação, nomeação e caracterização de organismos (TUNNICLIFFE, 1995). Essas instituições têm sido objeto de pesquisa em relação à sua atuação na sociedade e à sua contribuição para educação em ciências (MARANDINO, 2009; MARANDINO et al, 2008; ELLIS, 2002). Dessa forma, os museus cumprem um importante papel na educação dos indivíduos fora do ambiente escolar e ao longo da vida (KRASILCHIK; MARANDINO, 2004) e têm a intenção de melhorar a simpatia e a percepção pública sobre ciência (STOCKLMAYER, 2002).

Mas o que os museus oferecem para seus públicos? Que atividades educativas eles vêm desenvolvendo junto aos seus visitantes? Para responder essas perguntas e iniciar nossa exploração das atividades que os museus estão realizando atualmente, além de um levantamento bibliográfico, fizemos um breve levantamento exploratório junto a 38 museus brasileiros de 
temática biológica e que nos confirmaram seus endereços eletrônicos, que foram selecionados a partir de consulta ao Guia de Museus da ABCMC (ASSOCIAÇÃO DE MUSEUS E CENTROS DE CIÊNCIA DO BRASIL, 2009). Um questionário contendo perguntas sobre atividades desenvolvidas, público alvo, materiais educativos e seus objetivos, desafios na sua produção foi enviado por e-mail às instituições entre setembro e novembro de 2015 , recebemos respostas de 13 museus que afirmam desenvolver algum tipo de atividade educativa com seu público. Alguns exemplos delas são mediação humana nas exposições, cursos para professores e mediadores, palestras para o público em geral, seminários, apresentações teatrais, oficinas para escolas, professores e público geral, atividades de férias, feiras de ciências, visitas aos bastidores, empréstimo de material educativo, aulas em laboratórios, "contação" de histórias, observação com telescópio, programas em rádios locais, realização de atividades em datas especiais, sessão em planetário, trilhas, visitas técnicas, atendimento a pessoas com deficiência, atividades especiais aos finais de semana entre outras. Os museus respondentes deste levantamento afirmaram que, para a realização dessas atividades, costumam utilizar suportes diversificados, que vão desde recursos humanos até materiais impressos, visando uma maior interação entre os visitantes e o conceito da exposição.

As atividades educativas buscam também ser um facilitador na relação dos museus com seu público pelo seu caráter envolvente e sedutor. Outro desafio importante para os museus e que pode ser amenizado por essas atividades, é o de transformar a pesquisa realizada nestes locais em algo mais convidativo e acessível para a maior quantidade possível de pessoas (MARANDINO, 2009).

As necessidades de seus públicos passaram a ser o foco das preocupações das instituições museais a partir da década de 1970 (MARTINS, 2011) e a ênfase no caráter educativo desses espaços também é destacada na definição do Conselho Internacional de Museus (ICOM, 2011) "instituição aberta ao público... com finalidade de estudo, educação e fruição". Estas formas de olhar o público e a educação dentro dos museus criaram uma perspectiva de atuação voltada às necessidades de uma gama maior de pessoas, isto é, propiciar o acesso a públicos que, por motivos diversos não desfrutam deste espaço de aprendizagem ou demandam um aprofundamento conceitual, uma preparação para a visita ou um relacionamento especial com as coleções. A partir da existência de atividades diversificadas, como as citadas acima, presentes nesses espaços, tais expectativas e tendências têm a possibilidade maior de se concretizarem. 
Todas as ações brevemente abordadas neste item têm o objetivo de aproximar o público de conceitos, teorias, práticas e reflexões que contribuem para a formação integral do cidadão, contribuindo para o entendimento de fatos e políticas científicas, seu impacto na vida, no bemestar pessoal, econômico e social desse público (MARANDINO; KRASILCHIK, 2004; STOCKLMAYER, 2002; MARTINS, 2006). Tais finalidades estão totalmente articuladas com a ideia contemporânea de Alfabetização Científica.

Desta forma as ações educativas nos museus estão entre as iniciativas que contribuem para o processo de Alfabetização Científica (AC) dos cidadãos. A melhoria da qualidade de vida, decisões mais conscientes e autônomas dos cidadãos não podem ser feitas sem a participação de toda a sociedade. Frente à necessidade de inserir o público nos assuntos relacionados ao impacto da ciência e da tecnologia no nosso cotidiano, os museus de ciência mostram-se como instituições mediadoras do diálogo entre ciência e sociedade.

Os museus têm sido considerados locais importantes para promoção da AC (HENRIKSEN; FROYLAND, 2000; FEINSTEIN, 2011; CERATI, 2014; MINGUES, 2014). Dentre as atividades desenvolvidas pelos museus para seus públicos diversificados, gostaríamos de destacar a produção e utilização de variados materiais educativos. Entendemos aqui como materiais educativos uma gama ampla que inclui objetos biológicos conservados, mas também materiais impressos, audiovisuais, virtuais, entre outros. Podem ser materiais instrucionais destinados diretamente ao público visitante das exposições, que incluem conceitos científicos, mas também atividades lúdicas. Podem estar direcionados a públicos específicos, incluindo, por exemplo, materiais específicos como cadernos para professores, atividades para estudantes, folders e impressos em geral de divulgação científica, de divulgação do próprio museu e do seu acervo (CAMPOS, 2009). É intenção desta pesquisa analisar o potencial desses materiais educativos vastamente produzidos pelos museus na perspectiva da alfabetização científica.

Desse modo, este trabalho pretende responder as seguintes perguntas:

- Os materiais educativos utilizados nas diversas ações educacionais e culturais realizadas pelos museus contribuem para o processo de alfabetização científica do público?

- Como os materiais educativos usados pelos museus se articulam com os pressupostos da AC?

- Os pressupostos da AC se expressam durante as interações do público com os materiais educativos durante as visitas aos museus? 
- Como o público percebe aspectos da AC na interação com os materiais educativos durante as visitas?

Para o desenvolvimento deste estudo selecionamos analisar materiais de uma instituição especifica, o Parque Zoológico Municipal Quinzinho de Barros, em Sorocaba, SP, pelo relevante papel que esta instituição possui recebendo um total de 600.000 visitantes ao ano. Ele é reconhecido por várias entidades nacionais e internacionais como uma instituição de grande importância na educação ambiental, recebendo apoio do Fundo Nacional para a Natureza (WWF- EUA), Fish and Willdlife Service, Fundação o Boticário de Proteção à Natureza, entre outros. O Parque Zoológico Municipal Quinzinho de Barros é classificado pelo IBAMA na categoria A - a mais elevada, devido às condições de infraestrutura que possui (como transporte próprio, técnicos em regime integral de trabalho, biblioteca, auditório, laboratório e programa de educação ambiental). O reconhecimento do Zoológico de Sorocaba pela comunidade local se deu não só por ser um espaço de lazer e contemplação, mas também pelos trabalhos desenvolvidos nas diferentes áreas (biologia, veterinária e educação), tais atributos levaram o Zôo de Sorocaba a ser eleito pela comunidade local por voto popular em 1993, como "símbolo da cidade" (MERGULHÃO, 1997; ZOO SOROCABA, 2015). Esta instituição vem desenvolvendo ações educativas variadas, entre elas a produção de materiais educativos. Considerando o acervo de materiais deste Zoológico, o presente estudo optou por analisar os materiais educativos especificamente compostos por materiais biológicos conservados, modelos, réplicas e materiais de apoio desses objetos, a partir de dois pontos de vista: sob a perspectiva da produção pela equipe do Zôo, mas também na perspectiva da interação de um grupo de alunos do ensino fundamental I durante visita ao Zoológico.

Zoológicos são considerados museus, pela definição do IBRAM (2015). São uma das instituições mais visitadas no mundo e tiveram sua origem no século XVIII, na Europa (GARCIA, 2006). A grande atração desses espaços são os animais expostos que motivam todos os tipos de público a visitá-los, seja com o intuito de lazer ou aprendizagem. Essas instituições possuem um grande potencial para disseminação de informações sobre fauna e flora silvestre, além de promover reflexões sobre conservação ambiental, uso de animais na indústria e muitos outros temas relacionados. Portanto, jardins zoológicos podem também ser considerados espaços relevantes que podem contribuir para a AC de seu público. Em especial, nos interessa entender como uma ação específica do Zôo de Sorocaba, a produção e utilização de materiais educativos, pode contribuir para este processo. 


\subsection{OBJETIVOS GERAIS E ESPECÍFICOS}

Considerando que os jardins zoológicos são centros de educação não formal e partindo do pressuposto que os materiais educativos por eles produzidos estão entre as iniciativas que podem contribuir para o processo de Alfabetização Científica (AC) dos cidadãos, este trabalho tem os seguintes objetivos:

Gerais:

- Analisar se e como os materiais educativos utilizados nas diversas ações educacionais e culturais realizadas pelo Parque Zoológico Municipal Quinzinho de Barros em Sorocaba, contribuem para o processo de alfabetização científica do público.

\section{Especificos:}

- Identificar os materiais educativos utilizados pelo Parque Zoológico Municipal Quinzinho de Barros em suas ações educativas e culturais;

- Analisar se os materiais do acervo didático e aqueles usados nas visitas orientadas realizadas no Parque Zoológico Municipal Quinzinho de Barros, se articulam com os pressupostos da $\mathrm{AC}$;

- Analisar o potencial dos materiais educativos para a promoção da $\mathrm{AC}$ durante as interações destes com o público escolar nas visitas orientadas;

- $\quad$ Aplicar os indicadores e atributos de AC desenvolvidos por Cerati (2014); Rocha (2016) e Oliveira (2016), discutindo seus limites e possibilidades.

Esta pesquisa está estruturada em 7 capítulos. O próximo capítulo trata da contextualização histórica da origem da ideia de alfabetização científica, os vários caminhos trilhados e o conceito no âmbito da educação não formal. Nele, justificamos a nossa opção pelo uso do termo "alfabetização científica". No capítulo 3 faremos uma contextualização histórica do percurso e das transformações sofridas pela educação dentro dos museus e caracterizaremos os materiais educativos, discutindo a sua relevância e apontando algumas reflexões e análises que têm sido feitas sobre eles. No capítulo 4 é apresentada a metodologia utilizada na realização desta pesquisa. Os dados foram coletados e tratados em dois blocos: Bloco 1 - Concepção, produção, gestão e observação dos materiais educativos e Bloco 2 - Interação do público com os materiais 
educativos. Neste capitulo apresentamos também a ferramenta teórico-metodológica utilizada para a análise dos dados.

O capítulo 5 apresenta os resultados do trabalho na mesma estrutura tratados na metodologia, em dois blocos: Bloco 1 - Concepção, produção, gestão e observação dos materiais educativos e Bloco 2 - Interação do público com os materiais educativos.

No capítulo 6 refletimos sobre os resultados obtidos em nosso estudo, e os desdobramentos referentes às nossas questões de pesquisa.

O capitulo 7 elenca algumas conclusões a respeito da contribuição dos zoológicos para a alfabetização científica em geral e sobre a investigação dos materiais educativos do Parque Zoológico Municipal Quinzinho de Barros e sua contribuição para a alfabetização científica dos usuários. 
2. ALFABETIZAÇÃO CIENTÍFICA 
O exercício da cidadania hoje tem como algumas de suas dimensões o domínio das formas atuais de linguagem e dos princípios científicos e tecnológicos. Saber como lidar com o conhecimento científico com responsabilidade social e de forma crítica é uma das melhores formas para de promover a melhoria da qualidade de vida. Esses aspectos, entre outros, contribuem para o que muitos autores têm cunhado como alfabetização científica (AC), um processo que envolve, além do domínio de conceitos e a visão crítica sobre a ciência e a tecnologia, a dimensão da inclusão social, isto é, se constitui como um facilitador para que todos façam parte do mundo que nos cerca (CHASSOT, 2003). Entender a ciência e seu processo de construção contribuem para controlar e prever as transformações que ocorrem no ambiente, promovendo uma melhor compreensão do universo e da natureza, o que poderá levar a uma melhor relação do ser humano com o ambiente que o cerca (KRASILCHIK; MARANDINO, 2004; SABBATINI, 2014; CAVALCANTE, 1999; DEMO, 2010; CHASSOT, 2003).

Nesse sentido, torna-se importante discutir os diferentes significados e funções que se têm atribuído à alfabetização científica para nos auxiliar na análise e compreensão dos materiais educativos estudados nessa pesquisa.

Neste capítulo faremos uma contextualização histórica da origem da ideia de alfabetização científica, os vários caminhos trilhados, abordaremos o conceito no âmbito da educação não formal e explicitaremos a nossa opção pelo termo. Mesmo sabendo que vários destes aspectos já foram tratados em muitos trabalhos de pesquisa nacionais e internacionais, consideramos ser necessário destacar alguns aspectos marcantes do percurso deste conceito para contextualização da investigação aqui proposta.

\subsection{CONTEXTUALIZAÇÃO HISTÓRICA E PERCURSOS DO CONCEITO DE ALFABETIZAÇÃO CIENTÍFICA}

A preocupação crescente com a educação científica e, consequentemente com a $\mathrm{AC}$, considerada um resultado deste processo (OLIVEIRA, 2016), vem sendo defendida não só por educadores em ciências, mas por diferentes profissionais. Muitos autores vêm se debruçando sobre o tema há muito tempo Hurd (1958, 1998); Miller (1983); Bybee (1995); Norris e Phillips, (2003); DeBoer (2000) entre outros, buscando consolidar uma definição em meio aos numerosos significados, perspectivas e abordagem sobre o tema tanto no âmbito da educação formal quanto da não formal. As discussões também abordam a importância da divulgação da ciência em diferentes canais de comunicação e nas diferentes formas de educação como fator 
relevante para alfabetizar cientificamente a população e para que esta aprofunde os saberes adquiridos, formando, assim, um corpo de conhecimento que será utilizado para sua vida em sociedade.

A discussão sobre a $\mathrm{AC}$ surgiu em contextos muito diversos e os autores estão longe de chegarem a um consenso. Isso pode ser explicado pelo fato de $\mathrm{AC}$ ser um conceito amplo que depende do contexto histórico no qual ela é proposta e de pressupostos ideológicos e filosóficos (SANTOS, 2007).

A ideia de AC já se delineava desde 1620. Francis Bacon, Thomas Jefferson, Herbert Spencer e James Wilkinson já argumentavam sobre a necessidade de preparar as pessoas para o bom uso de suas faculdades intelectuais cujo caminho seria o conhecimento das ciências e seu ensino em todos os níveis para que o cidadão pudesse melhor compreender sua importância na sociedade (HURD, 1998).

Entretanto um dos primeiros autores a se utilizar do termo "Alfabetização Científica" foi Paul Hurd no trabalho de 1958 que discutiu o conceito no âmbito da educação formal. O autor questiona se o currículo norte-americano daria conta de formar cidadãos capazes de discutir criticamente o impacto das novas descobertas, principalmente após a II Guerra Mundial e das consequências sociais por ela provocadas. Neste período começou uma intensa preocupação, principalmente no contexto norte-americano, com o papel da educação em ciência no sentido de assegurar a soberania do país em relação às outras nações (LAUGKSCH, 2000). O lançamento do Sputnik em 1957 pela União Soviética, originou a impressão de inferioridade científica dos EUA e a ideia era de que isto se resolveria com uma rápida expansão do conhecimento científico, o que fez surgir um movimento que supervalorizou esse conhecimento em relação às demais áreas. Nessa perspectiva, iniciou-se uma corrida para a formação de jovens cientistas o que levou à formatação de projetos curriculares que enfatizavam a vivência da ciência por meio de experimentos científicos e que priorizavam a matéria ciência visando desenvolver nos estudantes o espírito científico, dentro da estrutura clássica das disciplinas científicas (HURD, 1998; LAUGKSCH, 2000; CERATI, 2014).

A ideia da AC consolidou-se entre os anos de 1950 e 1960, mesmo ainda sendo incompleta, difusa e com muitos significados, como afirma Laugksch (2000) no seu denso e importante trabalho de revisão sobre as publicações que tratavam do termo. Segundo o autor, diversos fatores contribuíram para isso: grupos com interesses e objetivos diversos na $\mathrm{AC}$, diferentes conceitos do termo e diferentes formas de mensurar são alguns dos fatores levantados. Para o 
autor, a relação entre cada um dos fatores acima possibilitaria diferentes combinações, o que resultaria em diferentes interpretações e percepções da AC. O resultado dessas diferenças e do enfoque dado pelos diferentes atores sociais em cada grupo de interesse geraria uma definição difusa e controversa como citado acima.

Laugksch (2000), faz ainda uma revisão histórica citando diversos pesquisadores que já tinham refletido sobre o conceito de AC. Ele inicia com o trabalho de Pella, O'Hearn e Gale (1996), que apesar de não conceituarem AC, propõem uma qualificação para um indivíduo ser alfabetizado cientificamente: ele deveria ter conhecimento das relações entre ciência e sociedade, saber sobre ética, conhecer a natureza da ciência, conhecer conceitos básicos, diferenciar ciência e tecnologia e perceber a relação entre ciência e humanidades.

Outro estudo citado por Laugksch (2000) é o de Shen (1975) onde ele define AC como o conhecimento em ciências, tecnologia e medicina, popularizado em vários níveis, para o público em geral e setores especiais de público, por meio de informações em massa e educação formal e não formal. Shen define três tipos de AC: prática, que ele postula como a aquisição de um tipo de conhecimento científico que auxilia o cidadão a resolver problemas práticos, tais como saúde e sobrevivência; cívica que possibilita a conscientização do cidadão sobre questões relacionadas à ciência para tomada de decisões dentro de uma sociedade cada vez mais tecnológica; e a cultural que se relaciona com a motivação de saber mais sobre ciência como um constructo e conquista humana. A caracterização de AC de Shen traz uma nova complexidade para o conceito que inclui questões do impacto da ciência na sociedade e a participação do cidadão nas decisões do coletivo social. A classificação deste autor coloca a ciência como uma cultura, com suas crenças, hábitos e modo de pensar específicos.

Outro trabalho citado por Laugksch, é o de Hazen e Trefil (1991) que diferencia o fazer ciência de usar ciência, segundo esses autores, não é necessário que a população faça ciência, mas deve saber como ela impacta sua vida, para eles alfabetização científica é o conhecimento que a pessoa deve possuir para entender os resultados divulgados pela ciência.

Jon Miller (1983) realiza uma discussão sobre a implicação do nível de AC da população para o estabelecimento de políticas científicas. Após revisão histórica do conceito e uma pesquisa com adultos a partir de 17 anos, ele propôs 3 dimensões da AC: o entendimento da natureza da ciência, a compreensão de termos e conceitos-chave das ciências e o entendimento dos impactos das ciências e suas tecnologias. Nessas dimensões podemos notar também a presença da visão da importância da participação popular inclusive para sustentar a ciência. 
Thomas e Durant (1987) defendem a participação e o entendimento mais ativo da sociedade em vários aspectos da ciência com 9 argumentos: (1) benefício para a própria ciência - o público apoiará a ciência se ele tiver o mínimo conhecimento do seu processo e seus produtos; (2) benefício para a nação - traria capacidade competitiva para a nação com pesquisa vigorosa; (3) influência e poder da nação - a formação de cientistas traria liderança internacional para o país; (4) benefício para o indivíduo - o indivíduo com conhecimento melhor de ciência teria melhores condições de optar por produtos dessa ciência; (5) benefício para um governo democrático fortalecimento do governo com a participação do cidadão; (6) benefício para a sociedade integração efetiva da ciência na cultura; (7) benefícios intelectuais - contribuição para uma mente educada e treinada; (8) benefícios estéticos - a ciência é uma atividade criativa e revelaria a ordem e a beleza do universo; (9) benefício moral - acesso do cidadão aos benefícios que a ciência pode trazer a ele. Os autores defendem que deveria haver uma combinação entre vários elementos para uma pessoa ser alfabetizada cientificamente, envolvendo conhecimento, atitudes e habilidades apropriadas. As pessoas alfabetizadas cientificamente devem ter conhecimentos científicos ligados ao seu cotidiano, devem ter habilidades para interpretar novos avanços em ciência e tecnologia, principalmente quando impactam sua vida.

No trabalho de 1998, Paul Hurd tenta caracterizar um indivíduo alfabetizado cientificamente: o cidadão deve perceber a distinção entre especialistas e não especialistas e entre ciência e pseudociência; deve compreender as várias dimensões da ciência e da tecnologia (política, judicial e ética); deve saber identificar os benefícios e os riscos da ciência e da tecnologia na vida das pessoas; deve entender os procedimentos da produção científica; deve desenvolver a capacidade de analisar e processar informações para levantar hipóteses a partir de evidências; deve conseguir utilizar os conhecimentos científico na tomada de decisões e reconhecer os pesquisadores como produtores de conhecimentos científicos e os cidadãos como usuários desse conhecimento; ter consciência de que o conhecimento científico está em constante construção e que é uma construção humana e está incluída num contexto histórico e cultural.

No livro The Myth of Scientific Literacy de 1995, Shamos argumenta que o verdadeiro grau de AC seria impossível de ser alcançado pela maioria das pessoas, pois exigiria um alto nível de cognição e, segundo o autor, nem mesmo os cientistas são considerados alfabetizados cientificamente em áreas da ciência fora de sua especialidade. Mesmo assim, ele propôs níveis hierárquicos de $\mathrm{AC}$. $\mathrm{O}$ mais simples seria a $\mathrm{AC}$ cultural relacionada à leitura de jornais, comunicação com representantes eleitos ou com o entendimento de debates sobre questões de políticas científicas; a AC funcional, que além de vocabulário científico, propõe que o indivíduo 
seja capaz de conversar, ler e escrever de forma coerente num contexto não técnico, mas significativo; AC verdadeira, que envolve as formas anteriores agregando a compreensão do processo investigativo da ciência, questionamento, raciocínio analítico, dedutivo e pensamento lógico, além da admiração pelo conhecimento científico.

Bybee (1995), citado por Roberts (2007) também apresenta três dimensões de alfabetização científica: a funcional, a conceitual e processual e a multidimensional. A alfabetização científica funcional está relacionada com a aquisição de um vocabulário científico que permita ao cidadão perceber que a ciência tem uma terminologia própria; alfabetização científica conceitual e processual, trata-se da atribuição de significados aos conceitos científicos, incluindo a compreensão relativa aos procedimentos e processos de construção do conhecimento científico; na alfabetização científica multidimensional as pessoas são capazes de adquirir e explicar conhecimentos e aplicá-los à solução de problemas do dia-a-dia. Nessa dimensão de Bybbe estão incluídos a história das ideias científicas, a natureza da ciência e da tecnologia e o papel da ciência e da tecnologia na vida pessoal e na sociedade.

Segundo Roberts, os trabalhos de Bybbe foram essenciais para a consolidação do conceito de $\mathrm{AC}$ na época, envolvendo fortemente a participação da sociedade nas decisões sobre ciência e tecnologia. Bybee (1995) postula que AC é o conhecimento e a compreensão dos conhecimentos e processos da ciência necessários para uma pessoa decidir e participar ativamente de assuntos políticos, culturais e econômicos (ROBERTS, 2007).

George E. DeBoer no seu trabalho de revisão histórica da educação científica (2000), concluiu que a alfabetização científica é um conceito geral que tem tido grande variedade de significados. Ele coloca que a alfabetização científica está relacionada à compreensão da ciência pelo público para que este viva de forma mais eficaz em relação ao mundo natural. $\mathrm{O}$ autor propõe que a alfabetização científica tem implícita uma compreensão ampla e funcional da ciência para fins de educação geral e não a preparação para a ciência e carreiras técnicas e que o importante é os alunos aprenderem algo que eles achem interessante para que eles continuem a se interessar por ciência no futuro - AC é algo que muda e cresce com o tempo. Podemos perceber que o autor considera que a $\mathrm{AC}$ não está restrita à escola, podemos considerar então os diversos espaços não formais como promotores de AC.

Outro autor que analisou o ensino de Ciências nos países ocidentais foi Gerard Fourez. No seu trabalho de 1994, ele afirma que a educação em ciências deve preparar os estudantes para atuar e interagir na sociedade a partir de temáticas científicas, por meio do processo de alfabetização 
científica, eles devem aprender, além dos conceitos, competências relacionadas com o modo de fazer e pensar a ciência e a tecnologia para que participem, como cidadãos críticos e responsáveis, num mundo em que os conhecimentos científicos são tão determinantes. Este processo é o que asseguraria uma participação mais atuante na sociedade em relação aos assuntos relacionados às ciências. No trabalho de 2003, Fourez discutiu os dois enfoques encontrados no ensino de Ciências: - (1) que visa a formação de cientistas e se ramificam em Física, Química, Biologia e (2) o que visa à formação cidadã, com abordagem de temas sobre meio ambiente, poluição, tecnologia, medicina, conquista espacial, história do universo e dos seres vivos etc. São duas concepções diversas de $\mathrm{AC}$ que podem se expressar de diferentes formas em relação à objetivos humanistas, sociais e econômicas e ter resultados diferentes dependendo do contexto em que são tratadas.

Em outro trabalho publicado em 2005, Fourez analisou o ensino de ciências na década de 1990 apontando que o ensino neste período se voltou mais para objetivos político-econômicos do que para os culturais e sociais. Os cursos secundários de Ciências e Matemática estavam centrados em disciplinas e especializações que visavam à formação de jovens preparados com excelência para as carreiras científicas e tecnológicas, resultando no aparecimento de uma elite que fez triunfar a investigação científica norte-americana. A partir de todas essas obras, o autor propõe uma definição para AC como a capacidade de o indivíduo utilizar os saberes das disciplinas a fim de enfrentar as situações de existência; portanto, o ensino pautado na AC visa a formação, a inserção e a capacidade criativa do indivíduo na sociedade.

A discussão sobre a função social do ensino de ciências continua se aprofundando e os conceitos de $\mathrm{AC}$ voltados para a participação da sociedade têm se consolidado como podemos observar no trabalho de Norris e Phillips (2003) que identificaram as seguintes características do cidadão cientificamente alfabetizado: a) conhecimento do conteúdo científico e habilidade em distinguir ciência de não ciência; b) compreensão do que é ciência e de suas aplicações; c) independência no aprendizado de ciência e habilidade para pensar cientificamente; d) habilidade de usar conhecimento científico na solução de problemas e na participação inteligente em questões sociais relativas à ciência; e) compreensão da natureza da ciência; f) apreciação e curiosidade por ela; g) conhecimento dos riscos e benefícios da ciência; h) habilidade para pensar criticamente sobre ciência.

Praia, Gil-Perez e Vilches (2007) discutem que a participação do cidadão na tomada fundamentada de decisões não exige do indivíduo um conhecimento profundo de ciência e que, 
com um mínimo de conhecimento científico e considerações éticas é possível para o cidadão contribuir com os especialistas sobre problemáticas que dizem respeito à sua vida e à vida da coletividade. Os autores ainda destacam que a participação da sociedade na tomada de decisões apressadas sobre inovações das quais se desconhecem as consequências, se torna positiva na medida em que se aplica o princípio da precaução, que se baseia na sensibilidade social frente às inovações que possam trazer riscos para as pessoas e para o ambiente. No entanto, os autores acima deixam explícito que essa participação requer o mínimo de conhecimentos, mas que é preciso superar o reducionismo conceitual e possibilitar um entendimento mais profundo que integre conceitos, procedimentos e filosofia.

Lucia Sasseron (2008) em sua tese de doutorado, realizou um estudo qualitativo para discutir os pressupostos, características e evidências da AC no Ensino Fundamental. A autora faz uma revisão bibliográfica sobre o termo alfabetização científica e suas várias interpretações nos vários idiomas em que aparece e, para ela, todos os autores analisados parecem ter a mesma ideia de formar o cidadão para atuar na sociedade, mas há variações dos termos em cada idioma. Em espanhol encontra-se o termo "Alfabetización Científica", em inglês "Scientific Literacy" e em francês "Alphabetisation Scientifique", todas com o mesmo significado de promover a capacidade e competências entre os cidadãos para permitir-lhes a participação nas decisões do cotidiano relacionadas a questões científicas. Já em português existem várias expressões para a mesma ideia e atualmente alguns dos autores que trabalham com ensino de ciência utilizam-se dos termos Letramento científico, Alfabetização científica e Enculturação científica. (SASSERON, 2008; VOGT, 2006; SASSERON; CARVALHO, 2011).

Autores como Sasseron (2008) articulam a ideia de alfabetização científica com a perspectiva educacional de Paulo Freire, assumindo que a alfabetização não é simplesmente se apropriar de técnicas de escrever e ler, de se apropriar dos signos e de seu entendimento, mas é dominar estas técnicas que em termos conscientes, implicaria em uma autoformação resultando numa postura interferente do cidadão sobre seu ambiente. (FREIRE, 1988, 1996; citado por SASSERON, 2008). Nessa perspectiva, podemos compreender o conceito de alfabetização de maneira ampliada, considerando a necessária compreensão do ato de ler não apenas a palavra, mas o mundo estabelecendo relações entre a palavra e o mundo. Freire (FREIRE, 1988, 1996; citado por SASSERON, 2008) aponta que o sujeito crítico, insatisfeito e indócil permite o surgimento de um sujeito pensante, transformador, criador, histórico e social. Nesse sentido, o termo "alfabetização científica" mostra-se adequado como um processo de conexão das pessoas 
com o mundo, por meio de reflexões que possibilitem a elas entenderem os processos e produtos da ciência, bem como utilizar o conhecimento para compreender melhor o mundo em que vive.

Sasseron (2008) fez uma revisão do tema na literatura nacional e internacional e propôs eixos estruturantes e indicadores de AC. A autora discutiu duas dimensões da AC: (1) estruturante (ações que demonstram os elementos na investigação e a estruturação das ideias) e (2) epistemológica (ações que se centram na busca por conexões e relações entre as variáveis identificadas). Com base nessas dimensões, ela propôs 3 eixos estruturantes para o ensino de

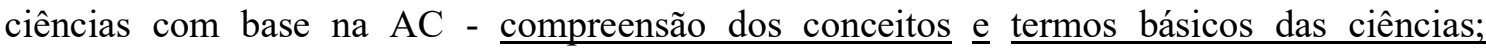
compreensão da natureza das ciências e relação entre ciência, sociedade, tecnologia e ambiente.

Sasseron e Carvalho (2011) fizeram uma releitura de diversos autores construindo uma importante revisão histórica do conceito de AC no contexto acadêmico brasileiro, apresentando como as ideias foram discutidas, identificando habilidades que os autores apontam como necessárias para um indivíduo ser alfabetizado cientificamente e reafirmando a proposta de Sasseron (2008) em relação aos eixos estruturantes da AC. As autoras consideram que "a alfabetização científica deve desenvolver em uma pessoa a capacidade de organizar seu pensamento de maneira lógica, além de auxiliar na construção de uma consciência mais crítica em relação ao mundo que a cerca" (SASSERON; CARVALHO, 2011, p. 67) e propõem a alfabetização científica como objetivo para a formação de cidadãos críticos com vistas à atuação na sociedade.

Outra autora brasileira relevante nesta revisão é Krasilchik (2009), que afirma que a AC na escola engloba muitas facetas e controversas sobre o seu significado; mas entende que os alunos devem entender a ciência em três sentidos: como produto, ou seja, como um conjunto de fatos, dados, conceitos e ideias fundamentais que compõem o acervo de conhecimentos produzido pela humanidade; como processo, que exige rigor na coleta e na interpretação de dados para a construção de conhecimentos; e como instituição, que analisa as suas implicações sociais, refletindo os valores dos cientistas congregados para servir à sociedade.

O termo alfabetização científica, como pudemos notar nos parágrafos acima, abarca uma gama grande de significados que podem ser desde buscar uma participação da sociedade em questões de ciência e tecnologia até tentar referendar os modelos científico-tecnológicos atuais (AULER; DELIZOICOV, 2001). Neste trabalho, Auler e Delizoicov (2001) investigaram as concepções de professores sobre as atividades científicas e tecnológicas. Eles observaram que ainda existem alguns mitos em relação à concepção deles sobre ciência: o mito da neutralidade da ciência, o 
mito da perspectiva salvacionista da ciência, o mito da superioridade tecnocrática e o mito do determinismo tecnológico. Dependendo do que é assumido pelo educador em ciência, os encaminhamentos podem ser bastante diversificados. As concepções de neutralidade e superioridade tecnocrática podem gerar um modelo de alfabetização científica que transfere aos especialistas os problemas e decisões que podem ser de todos os cidadãos. Esses mitos têm uma tendência a reduzir e limitar o debate sobre questões científicas que dizem respeito a toda a sociedade.

Podemos perceber que as discussões sobre AC incluem sempre dois grandes grupos: um que está relacionado à especificidade do conhecimento científico e outro que abrange as questões relativas à sua função social. Não seria o caso de propor uma dicotomia entre estes dois aspectos, pois eles estão totalmente inter-relacionados. Segundo Santos (2007), pela natureza do conhecimento científico, não se pode pensar no ensino dos conteúdos científicos de maneira neutra, sem a contextualização social, nem se pode discutir a função social do conhecimento científico sem a compreensão do seu conteúdo.

Em consequência desta percepção e da rápida e implacável incorporação da ciência e da tecnologia à vida das pessoas, uma nova perspectiva de alfabetização científica tem se consolidado e diz respeito a considerar que ela deve possibilitar uma leitura crítica do mundo fomentando ações sociais transformadoras (AULER, 2003). Esta abordagem é tratada com uma perspectiva que busca o entendimento das relações entre ciência e sociedade considerando o contexto histórico e social dos conceitos científicos e da articulação entre a $\mathrm{AC}$ e a participação social nos debates sobre temas contemporâneos, sendo importante evidenciar o caráter humano e cultural das tecnologias e das ciências, com o objetivo de fortalecer uma reflexão crítica e participativa. (AULER; DELIZOICOV, 2001; AULER, 2003; LAUGKSCH, 2000; NORRIS; PHILLIPS, 2003; FOUREZ, 1997, 2005; SANTOS, 2007).

Krasilchik e Marandino (2004) apontam que conhecer os diferentes aspectos da ciência, incluindo informações sobre como é produzida e suas dimensões conceituais, sociais, políticas, culturais e éticas, é fundamental. É sabido que os conhecimentos relacionados às ciências podem favorecer a tomada de decisões, de forma mais consciente, sobre questões da vida pessoal, social e profissional. Para as autoras, é nessa direção que o ensino de ciências, na escola, e a divulgação da ciência realizada pelos diferentes espaços de cultura científica podem avançar em relação à formação contemporânea. As autoras também destacaram, neste mesmo trabalho, a importância da relação do avanço do conhecimento científico com desenvolvimento 
econômico fazendo surgir nos anos de 1980 o movimento "ciência, tecnologia e sociedade" no contexto educacional, que leva em conta a importância atual da ciência na tecnologia, indústria, saúde, na qualidade de vida, e pressupõe uma visão interdisciplinar quebrando as rígidas fronteiras disciplinares.

Assim, a ideia de AC tem sido abordada, mais recentemente, levando em conta o contexto social (DEBOER, 2000). Segundo o autor, muitos currículos nos EUA têm adotado a concepção CTS formalmente, assumindo que o objetivo da educação científica é desenvolver indivíduos cientificamente alfabetizados que entendam como a ciência, a tecnologia e a sociedade se influenciam mutuamente e que sejam capazes de usar esse conhecimento no seu dia-a-dia para tomar decisões (DEBOER, 2000).

Para Fourez $(1997,2005)$ uma pessoa só poderá ser considerada alfabetizada científica quando seus conhecimentos e habilidades lhes permitirem certo grau de autonomia, certa habilidade de se comunicar e certo grau de controle e responsabilidade em negociar com problemas específicos (técnico, emocional, social, ético e cultural). Faz-se necessário que se saiba que os saberes são produções humanas sendo importante evidenciar o caráter humano e cultural das tecnologias e das ciências tendo em vista fortalecer uma reflexão crítica e participativa.

Vários trabalhos no âmbito do GEENF - USP (Grupo de Estudo e Pesquisa em Educação Não Formal e Divulgação em Ciência da Faculdade de Educação da Universidade de São Paulo), trabalharam vários aspectos da $\mathrm{AC}$ e propuseram conceitos na perspectiva da formação de cidadãos críticos com capacidade de participar de decisões sobre ciência.

Moreira (2013) afirma que parece haver um consenso na direção de que alfabetização científica significa adquirir os conhecimentos científicos e tecnológicos necessários para o desenvolvimento da vida diária, para ajudar a resolver problemas e as necessidades de saúde e sobrevivência básica, conscientizar-se e posicionar-se politicamente diante das complexas relações entre ciência, tecnologia e sociedade.

Na sua tese de doutorado, Tania Cerati (2014) define AC como:

“... um processo que ocorre ao longo da vida, com a finalidade de capacitar as pessoas para entender e se apropriar dos conhecimentos relacionados à ciência, seja com relação aos seus conhecimentos, seja no que se refere aos processos de produção e suas intricadas relações com a sociedade" (CERATI, 2014, p. 37). 
$\mathrm{Na}$ dissertação de 2014, Eliane Mingues propõe que o conceito de alfabetização científica pressupõe o ensino de ciências preocupado com a formação dos jovens para ação e atuação na sociedade.

Oliveira (2016) em sua tese de doutorado estudando como a Biodiversidade aparece nas políticas públicas de divulgação científica, assume a perspectiva CTS (Ciência-Tecnologia e Sociedade) de AC que busca a compreensão do impacto da ciência e tecnologia sobre a sociedade e a compreensão pública da ciência na formação para a cidadania com a intenção de abrir-se à compreensão das interações entre ciência-tecnologia-sociedade.

Como podemos perceber pelas discussões acima, diversos autores consideram que o objetivo da proposta CTS na educação é desenvolver a alfabetização científica e tecnológica dos cidadãos e tem como meta auxiliar na construção de conhecimentos, habilidades e valores necessários à tomada de decisões sobre assuntos de ciência e de tecnologia na sociedade e atuar na solução de temáticas relacionadas.

Nesta pesquisa corroboramos com a proposta de Contier e Marandino (2015), que trazem uma reflexão sobre os conceitos de $\mathrm{AC}$ e propõem uma definição com base em vários autores (MILLER, 1983; BYBEE 1995; FOUREZ, 2003) e nas pesquisas de Cerati (2014); Moreira (2013); Mingues (2014), já citadas. Assim, para nós AC é assumida como:

“... um processo que ocorre ao longo da vida e pressupõe o conhecimento dos conceitos científicos básicos, noções sobre sua epistemologia, a conscientização sobre as complexas relações entre ciência, tecnologia e sociedade almejando a participação ativa e o posicionamento dos cidadãos (CONTIER; MARANDINO, 2015, p. 5).

O movimento de AC foi vinculado ao ensino formal e para a formação de cientistas, mas com as mudanças na sociedade e os avanças científicos influenciando muito a vida do cidadão, seus objetivos se ampliaram e a discussão passou a ser a necessidade de formar cidadãos capacitados a discutir a influência da ciência na sociedade (BYBEE, 1995; ROBERTS, 2007).

Parte significativa deste processo acontece a educação formal, mas outras situações e instituições contribuem para seu desenvolvimento (LORENZETTI; DELIZOICOV, 2001). Cada vez mais a sociedade entende a educação como processo que não acontece somente no espaço da escola, além de não se limitar ao período de formação escolar (CAZELLI; FRANCO, 2001). Nesse contexto, os ambientes não formais de educação passam a figurar como espaços de informação e diálogo entre ciência e o público. 
A preocupação com a alfabetização científica sempre esteve presente nos museus e outros locais de educação não formal com temáticas científicas. Na literatura, eles são reconhecidos como espaços propícios para o ensino não formal de ciências e a alfabetização científica, bem como um dos locais mais antigos de mediação entre a sociedade e a ciência (DELICADO, 2009). Muitos autores têm discutido o papel dos espaços de educação na promoção da $\mathrm{AC}$ e da importância que estes espaços deem voz ao público para que este se torne um protagonista em torno dos temas de ciência e tecnologia (LEMKE, 2006; FEINSTEIN, 2010; CAZELLI, 1992; HENRIKSEN; FROYLAND, 2000).

Na próxima sessão vamos explorar um pouco a AC nos museus. Entendendo aqui Museus como instituições "sem fins lucrativos que conservam, investigam, comunicam, interpretam e expõem, para fins de preservação, estudo, pesquisa, educação, contemplação e turismo, conjuntos e coleções de valor histórico, artístico, científico, técnico ou de qualquer outra natureza cultural, abertas ao público, a serviço da sociedade e de seu desenvolvimento" (IBRAM, 2015).

\section{2. ALFABETIZAÇÃO CIENTÍFICA EM MUSEUS}

Lemke (2006) discute as novas formas e espaços de aprendizado. Ele coloca que este pode ter lugar em diferentes escalas de tempo desde que iniciamos na escola até o resto de nossas vidas, ocorre em vários locais e se processa através de muitos meios (linguagens, vídeos, simulações, materiais, desenhos, gráficos e muitas outras ferramentas) e que a aprendizagem é tanto melhor quanto mais mescladas forem as idades entre os aprendizes, adultos e crianças juntos, trocando suas experiências de vida.

Fensham, (1999) e Cazelli e Franco (2001) ressaltam o fato de que o conhecimento que o público tem de ciência atualmente não vem somente da educação formal, e sim dos meios de divulgação científica, da mídia eletrônica de qualidade e da intervenção dos museus de ciência. O fortalecimento de instâncias não escolares de educação devido ao contexto mundial de transformações rápidas, de modernização da sociedade e de redefinição do tempo e do espaço social são fundamentais para incluir os cidadãos nos contextos científicos atuais.

Desde sua origem, os museus passaram por transformações que mudaram o eixo de sua atuação: do cuidado com as coleções para a atenção com o público (MARTINS, 2006). Portanto, é relevante que a educação nos museus deva considerar a alfabetização científica como um dos meios para a formação de cidadãos críticos que participem de forma ativa na sociedade na qual 
estão inseridos, a fim de amenizar a exclusão social. Nesta perspectiva, a ciência, nesses locais, deve ser apresentada de forma a não só dar acesso ao conhecimento científico e tecnológico, como também aumentar a oportunidade de participação do público em questões científicas e tecnológicas visando sempre à alfabetização científica de seus visitantes (SILVA; JUNIOR, 2006).

Alguns autores problematizaram a relação dos museus com a AC do cidadão. Cazelli (1992) iniciou esse debate afirmando que os princípios da ciência não são dominados por grande parte da população e a educação nos museus pode ser uma maneira de atacar o problema. Essas instituições culturais podem funcionar especialmente para indivíduos que já concluíram sua formação acadêmica e é um tipo de oportunidade de auto formação ligada à informação, entretenimento e aprendizagem. Ela também salienta que muitas exposições têm levado em consideração a experiência dos visitantes para organizar as informações que serão apresentadas nas exibições e essa educação continuada contribuiria para o aumento da alfabetização científica da sociedade.

Feinstein (2010) debate sobre o conceito de AC dizendo que este é um processo de conexão entre a ciência e a experiência de vida do público dentro de seus próprios contextos sociais. $\mathrm{Na}$ maioria das vezes, as pessoas procuram entender e acessar temas científicos que lhes interessam e, assim, enriquecem o entendimento de suas próprias vidas. Portanto, concordamos com Feinstein e defendemos que os museus (incluindo os zoológicos) são espaços que possibilitam a conexão entre as pessoas e a ciência. Nesses locais deve haver a problematização dos fatos científicos motivando o visitante a questionar e refletir sobre temas científicos com relevância social. Refletir sobre um tema pertencente ao contexto social do visitante com base no conhecimento científico apresentado, possibilita ir além das percepções cotidianas, que, normalmente estão estruturadas no senso comum, ampliando, assim, a visão de mundo do visitante e possibilitando o seu engajamento com a ciência (CERATI, 2014).

Ao discutir AC, Feinstein (2010) defende que os cidadãos integram ideias científicas com a sua experiência de vida para refletir e tomar decisões pessoais e sociais. Para o autor, as pessoas podem, nos museus, fazer a ligação entre os assuntos tratados nestas instituições com alguma influência sobre suas vidas e desenvolverem a capacidade de interagir com os conhecimentos científicos para ajudá-los a alcançar seus próprios objetivos, ou seja, o público aprende a reconhecer como a ciência é importante para a vida. 
Mora (2011) discute a contribuição dos museus para a alfabetização científica e afirma que esta vai mais além do que aprender termos e símbolos e está relacionada à aplicação desses conhecimentos para a resolução de problemas e avaliação crítica das informações disponíveis. Neste trabalho, ela afirma que o tempo que o visitante passa na frente de um objeto numa exposição serve também para proporcionar a criação de significados de alguns conceitos científicos que poderiam contribuir para a alfabetização científica. Afirma ainda, que o benefício de uma visita aos museus seria a compreensão mais ampla de fenômenos científicos e uma mudança de atitude em relação à ciência e que essa experiência é pessoal e está relacionada com os interesses e conhecimentos prévios dos visitantes. Esses dados foram corroborados pela investigação que a autora fez em uma exposição comparando as lembranças, entre seis meses e um ano, em pessoas que já conheciam o tema (professores) e outras consideradas público leigo (visitante espontâneo).

Nessa perspectiva, Falk e Dierking (2012) defendem que os indivíduos aprendem a partir de sua necessidade e interesse, e que esses fatores são mais eficientes do que os impostos, por exemplo, pela escola. Portanto, cada pessoa é suscetível a ter um conhecimento diferente de ciência que está dependente de suas necessidades, habilidades e contexto histórico e social.

Para Henriksen e Froyland (2000), compreender os conceitos e processos científicos também requer capacidade de aplicação e identificação nas experiências cotidianas. Para as autoras os museus são instituições que facilitam encontros, diálogos e integração entre os vários grupos ali presentes e que oportunizam um diálogo de qualidade para eles. Para elas, os museus podem promover encontros, cursos e workshops que discutam questões científicas relevantes para o público, inclusive utilizando-se de suas coleções para trazer debates importantes e que tenham relação com o cotidiano da sociedade. Isto faz com que a identificação público-ciência se dê com maior facilidade.

Pérez e Moliní (2004) salientam que esses espaços desempenham um papel importante nos processos de divulgação científica. Este termo é compreendido como uma expressão que abarca toda a atividade de explicação e difusão do pensamento e dos conceitos científicos. A divulgação das mensagens da ciência é uma atividade de comunicação e cumpre as seguintes funções: informativa (aproximar o tempo das descobertas científicas com a sua divulgação na sociedade); cultural (articulação com o enriquecimento cultural local); educativa (complementação da educação formal e qualificação da opinião sobre os temas em questão); social (aproximação dos temas de ciência e tecnologia com os projetos da sociedade em uma 
dinâmica participativa); econômica (relação entre ciência, tecnologia e setor produtivo) e político-ideológica (democratização da ciência e participação da maioria nesse campo).

Ana Delicado (2004) faz uma análise das funções e finalidades dos espaços de musealização da ciência em Portugal. Alguns dos objetivos do trabalho foram refletir sobre os museus como espaços de ligação entre a ciência e a sociedade, sobre as políticas de promoção da cultura científica e sobre a ligação entre a produção e a divulgação da ciência. A autora defende que, além das funções comuns a qualquer tipo de museu (adquirir, conservar, pesquisar, comunicar e expor), os museus científicos desempenham algumas funções sociais, como difundir a cultura científica, consciencializar para a preservação do ambiente, despertar vocações, além da formação de especialistas. Neste trabalho a autora também debate sobre as funções que os museus científicos podem desempenhar e, segundo ela, não têm feito: discutir questões controversas, possibilitar a participação pública em questões técnico-científicas, apresentar os desenvolvimentos e descobertas da ciência, mostrar os impactos sociais da ciência, apresentar os processos da ciência atualmente. A autora conclui que exposições e atividades com estas finalidades são importantes para promover o debate sobre a ciência contemporânea.

Como pudemos perceber nos parágrafos anteriores, conhecer os vários aspectos da ciência, como ela é produzida, suas dimensões sociais, políticas e culturais, é hoje fundamental para a formação do cidadão (MARANDINO, 2014). O protagonismo do cidadão também é fundamental para que ele se aproprie das questões científicas (AMODIO, 2008; DELICADO, 2009) proporcionando a AC. Alguns autores, no entanto, têm questionado se os museus, de fato têm desempenhado esse papel.

Delicado (2009), em seu trabalho de análise sobre uma exposição tratando de um tema controverso em um museu de Portugal, defende que os museus são um dos mais antigos meios de comunicação entre o cidadão e a ciência. Eles refletem o que acontece no meio científico: descobertas, teorias dominantes e paradigmas, pesquisas consideradas importantes e úteis. Porém, a autora argumenta que a conexão entre a ciência e a sociedade tem permanecido fraca. Para ela, as descrições dos conteúdos das exposições científicas, especialmente aquelas com temas controversos, mostram que a ciência ainda é retratada como indiscutível e inequivocamente benéfica e o público é julgado como ignorante e sem preparo. O papel dos museus como espaços de debate e troca de ideias ainda é incipiente. A autora propõe que os museus deveriam ter uma postura mais ativa e reflexiva, aprofundando esta discussão 
utilizando-se de seu grande valor como instituição pública e com fortes laços com a comunidade científica.

Amodio (2008) faz uma discussão similar à Delicado (2009) e questiona se, de fato, a função de proporcionar o diálogo e a troca com o público está se concretizando nos museus. O autor coloca que existe uma crise de diálogo entre o cientista e a sociedade. Mas ele também anuncia que a sociedade tem se manifestado no sentido de que sua voz seja ouvida nesses espaços e apresenta as várias ações que têm sido desenvolvidas nos museus para fazer face a essa demanda do público como protagonista.

Massarani (2012) discute que nos museus da América Latina o público continua a ser tratado como analfabeto em ciência e a receber conteúdos neutros e descontextualizados socialmente. A autora coloca que a divulgação da ciência muitas vezes é unidirecional sem considerar a audiência como protagonista. Neste trabalho, a autora apresenta várias iniciativas de museus brasileiros que têm o público como protagonista em suas atividades com o objetivo de propiciar uma apropriação e um exercício mais profundo de cidadania em torno de questões científicas. Uma das maneiras de se chegar a este objetivo, é desenvolver atividades e exposições desafiadoras e que proporcionem a participação do cidadão.

Valdecasas e Correas (2010) escreveram um artigo analisando o papel de museus de história natural na AC em países como Itália, EUA e Reino Unido. Os autores defendem que os museus de ciência e história natural podem desempenhar um papel importante para uma sociedade alfabetizada cientificamente indo além da simples apresentação dos conteúdo e teorias, expandindo suas exposições e atividades para que apresentem os processos utilizados na produção da ciência, exercitando o pensamento crítico e lidando com a incerteza. Exposições novas e produtos criativos e instigantes devem ser criados para atrair o público e confrontá-lo com o conhecimento produzido e que pode melhorar a vida do cidadão, bem como com os modos de pensar que os ajude a ter uma visão crítica de assuntos científicos relacionados com a vida pessoal e da coletividade.

Cerati (2014) acredita que as exposições, ao compartilharem com o público o conhecimento produzido pela ciência, possibilitam aos visitantes sua apropriação. Na mesma direção, Rennie e Johnston (2004) afirmam que uma visita ao museu pode trazer uma multiplicidade de experiências podendo gerar resultados afetivos, sociais e culturais. Portanto, os visitantes dispostos a ler criticamente as informações disponíveis na exposição e participar das ações 
educativas estabelecendo relações com seu cotidiano e seus conhecimentos prévios estariam aprimorando sua AC.

Percebe-se que os museus contribuem para o aprofundamento do saber e para a aquisição de novos conhecimentos e possuem grande potencial para a educação em ciências contemplando diferentes perspectivas da alfabetização científica (MOREIRA, 2013; CERATI, 2014). Nessa perspectiva, assumimos que os museus são espaços com enorme potencial para contribuir com a alfabetização científica da população. Partindo da premissa que AC é um processo que ocorre ao longo da vida, em vários espaços de educação e que, entre outras coisas, visa instrumentalizar o cidadão para discutir e decidir sobre questões científicas que o impactam, os museus desenvolvem muitas ações que podem contribuir para este processo (CAZELLI, 1992; CERATTI, 2014; MINGUES, 2014; BYBEE, 1995). Além das exposições, principal forma de encontro entre os museus e seus públicos, estes espaços promovem cursos, oficinas, atividades lúdicas e culturais e, ainda, elaboram materiais educativos que apoiam muitas dessas ações, sendo também estas formas potencialmente relevantes para a promoção da AC nesses locais. Assim sendo, nesta pesquisa buscamos estudar a contribuição, mas também os limites dos materiais educativos produzidos por um zoológico no processo de AC do público. Antes, porém vamos aprofundar as características da educação em museus e, em especial, as especificidades dos materiais educativos elaborados nestas instituições. 


\section{EDUCAÇÃO EM MUSEUS E MATERIAIS EDUCATIVOS}


A função educativa dos museus não é mais contestada e, hoje, os museus são considerados instituições de caráter público com objetivos de difusão cultural e de educação. Essa perspectiva, no entanto, é relativamente recente. Nem sempre os museus foram instituições públicas ou tiveram como meta atrair o público amplo para seu interior. A dimensão educativa dos museus vem sendo construída ao longo da história dessas instituições e se estabeleceu de forma mais consistente e sistemática entre os séculos XIX e XX.

Neste capítulo faremos uma contextualização histórica do percurso e das transformações sofridas pela educação dentro dessas instituições e sua consolidação como uma de suas funções prioritárias. Em seguida iremos caracterizar uma das ações educativas desenvolvidas pelos museus e alvo desta investigação, a produção e utilização de materiais educativos, discutindo a sua relevância e apontando algumas reflexões e análises que têm sido feitas sobre eles. Pretendemos com isso justificar a importância de estudar essas produções educativas e de analisar seu papel para o desenvolvimento do processo de AC junto ao público.

\subsection{ASPECTOS DA TRAJETÓRIA DA EDUCAÇÃO NOS MUSEUS}

A relação entre os museus e seus públicos mudou com o passar do tempo e esteve relacionada ao contexto histórico, à relação da sociedade com esta instituição e de seu papel como organização educativa. Atualmente, os museus visam a inclusão dos públicos e a ampliação do papel de seus setores educativos no desenvolvimento de exposições e outras ações educativas, inclusive a produção de materiais educativos. No entanto, nem sempre os museus tiveram a preocupação com o acesso do público às suas dependências, coleções e conteúdos.

Alguns autores traçaram um panorama sobre as mudanças conceituais que consolidou a dimensão educacional e permitiu a divulgação dos museus e suas coleções (MARTINS, 2011; MARANDINO; MARTINS, 2016; VALENTE, 2003, 1995). Em meados XVI, com as viagens dos exploradores europeus ao Novo Mundo e ao Oriente as coleções de objetos naturais e artificiais começaram a se formar e eram abrigadas em salas especiais, casas de nobres ou reis e tinham acesso restrito aos conhecidos dos proprietários. Estes locais ficaram conhecidos como Gabinetes de Curiosidades e sua organização era baseada no princípio da raridade, novidade, harmonia e circulação do visitante no sentido de dar impressão de cenário e articulação entre natureza, arte e teatro. Podemos identificar neste momento um embrião de preocupação da relação desses objetos com o estudo e a pesquisa. Mas naturalmente, como eram coleções e espaços privados com acesso restrito, não podemos caracterizá-los, ainda como públicos, já que 
as visitas eram ligadas ao prestígio do visitante ou ao interesse na troca de conhecimento (MARTINS, 2011).

A partir do século XVII houve uma mudança no modo de pensar e na organização das coleções, especialmente as de zoologia, botânica e geologia, que passaram a ter um caráter taxonômico, de demonstração para o estudo e a pesquisa. Esta perspectiva levou à abertura dessas coleções para um público mais amplo. Valente (2003) interpreta que isso se deu pela pressão de estudiosos amadores, médicos e cientistas que queriam ter acesso a elas. Várias instituições permitiram o acesso à suas coleções, entre elas podemos citar o Ashmole Museum e o British Museum; o primeiro destinou sua coleção de artefatos naturais para a utilização no curso de História Natural da Universidade de Oxford e abriu a visitação das coleções em horários prédeterminados, contribuindo assim para a instrução pública. O segundo, passou a disponibilizar suas coleções para o estudo e pesquisa científica (MARTINS, 2011; MARANDINO; MARTINS, 2016).

Esse processo criou um aumento da valorização desses objetos fazendo com que houvesse um afastamento da população geral dos museus e eles passaram a ser um local de produção de conhecimento científico, recebendo quase que exclusivamente os indivíduos que tinham poder e saber. Isto se refletia na maneira como os objetos eram exibidos para o público, pois eram expostos em sua totalidade com critérios científicos e sem uma preocupação didática (VALENTE, 1995). Apesar de excludente para a população geral, os museus, neste período, foram muito importantes para o estabelecimento das disciplinas específicas como a História, Biologia, Antropologia, Geologia, entre outras (MARTINS, 2011).

A partir do século XIX, as ideias democratizantes da Revolução Francesa incentivaram o viés educativo dos museus expondo suas coleções de maneira mais didáticas e incrementando diversos tipos de atividades educativas voltadas para o público, em especial quando houve a sistematização de ações de recepção a escolas e de preparação de material de apoio como por exemplo, kits de objetos para empréstimo às escolas e que chegavam aos professores para utilização em sala de aula (MARANDINO; MARTINS, 2016; MARANDINO et al, 2016).

A tensão sobre o papel dos museus, dando ênfase por um lado a coleta e salvaguarda de coleções e, por outro, a educação e comunicação, vem sendo abordada tanto na prática educacional como nos eventos e reflexões da área. Martins (2011) analisa diversas conferências e encontros que discutiram o espaço ocupado pela educação nos museus e as outras funções que essa instituição desempenha. As discussões nesses diversos fóruns foram na direção de questões como: é a 
função de coleta e estudo de coleções ou a função social de educação e comunicação que deve ser a tônica dos museus? As diversas conferências do ICOM (Conselho Internacional de Museus) que ocorreram desde 1947, debateram as diferentes concepções de museus relacionadas às várias abordagens que esta instituição vem assumindo com o passar do tempo. Uma das primeiras reuniões internacionais que discutiram a temática educacional nos museus foi em 1952 nos EUA (Seminário Internacional da UNESCO) e tinha como objetivo debater os métodos para aperfeiçoar a educação de jovens e adultos nestes locais. Os participantes do evento refletiram sobre estratégias e práticas educativas nos museus enfatizando aspectos como a qualificação dos profissionais dos setores educativos, a melhoria da relação com o público escolar, a formação de professores, a inclusão de pessoas com deficiência e a utilização dos objetos das coleções como a base para o trabalho educativo nos museus.

O evento citado acima desembocou em diversos reuniões na América Latina e no Brasil. Uma delas foi o Seminário Regional da UNESCO sobre a função educativa dos museus, realizada em setembro de 1958 no Rio de Janeiro, quando se buscou legitimar o papel educativo dos museus como função institucional em equilíbrio com suas outras funções (coletar, investigar, conservar). Outra recomendação oriunda deste evento, foi o estímulo à relação entre as exposições e a educação como potencial para a ação transformadora dessa instituição e o incremento do uso dos próprios acervos como os melhores recursos a serem utilizados para o diálogo com o público (RIVIÈRE, 1958).

Um encontro marcante que discutiu o engajamento social dos museus, o uso social do patrimônio e o conceito de museu integral a serviço do desenvolvimento, enfocando seu potencial de comunicação como instrumento de diálogo entre atores sociais, foi a "Mesa redonda sobre a importância e o desenvolvimento dos museus no mundo contemporâneo", realizada em maio de 1972 em Santiago do Chile. O documento final do evento propõe, entre outras coisas, a modernização da comunicação entre o visitante e o museu promovendo o máximo de acesso às suas coleções. Para isso, a mesa redonda entende que os setores educativos dos museus devem ser organizados e integrados aos sistemas de ensino na forma de visitas de escolares, formação de professores e produção de materiais educativos, como impressos, audiovisuais entre outros (NASCIMENTO JUNIOR; TRAMPE; SANTOS, 2012).

Desse modo, desde meados do século XX, os museus vêm aprofundando sua função educativa e hoje são considerados "espaços de educação integral, organizados, com conhecimento historicamente construído, compartilhado e reproduzido por sujeitos ativos" (BIZERRA, 2009, 
p.23), sendo ainda espaços de ação social transformadora. Portanto, para que haja a aproximação do público com o conhecimento produzido neste espaço é necessário que esta instituição não se limite a abordar fenômenos científicos mas envolva seus públicos em diálogos sobre a ciência, tecnologia, inovação, questões sociais e pesquisa científica.

Para Valente (2005), um dos desafios para os museus atuais é contemplarem em suas ações a ligação entre as áreas das ciências naturais e humanas, procurando articular a história, a filosofia e a sociologia da ciência e aproximar os interesses éticos, culturais e políticos dos indivíduos, tornando seus assuntos mais estimulantes e reflexivos e incrementando a capacidade de pensar criticamente do cidadão. Para a autora, a inclusão de temáticas relacionadas à natureza da ciência auxiliam na compreensão de como as ideias científicas e seus usos mudam dependendo do contexto social, cultural e política em que se desenvolvem. Tais ideias corroboram aquelas apresentadas por Miller (1983) e Santos (2007) entre outros autores, que desde os anos de 1950 vêm refletindo sobre a questão da $\mathrm{AC}$ da população e o papel educativo dos museus neste processo. Nesta direção os museus de ciências em especial, têm sido cada vez mais destacados como locais promotores deste processo.

Desse modo, a partir do século XX o público passa a ser a peça chave na montagem das exposições nos museus de ciência e ampliam-se as experiências que abordam aspectos históricos e sociais da produção da ciência e o impacto desta na sociedade. Há também um aumento de programas educativos relacionados a estas temáticas (MARANDINO et al, 2009). Neste sentido, é cada vez mais reforçada a ideia de que a educação nestes espaços deve promover a formação de cidadãos críticos e ativos na sociedade (KRASILCHIK; MARANDINO, 2004; CAZELLI, 1992; FEINSTEIN, 2010; MORA, 2011).

\subsection{PARTICULARIDADES DA EDUCAÇÃO NOS MUSEUS}

A vocação educativa do museu está expressa na própria definição de museu proposta pelo ICOM, a qual elenca as funções de preservar, conservar, pesquisar, comunicar e expor, à serviço da sociedade, voltadas para o estudo, o deleite e a educação (ICOM, 2001). Contudo, como vimos anteriormente, os museus vêm assumindo essa função de forma paulatina e entre tensões sobre sua função social, de pesquisa e conservação.

Carvalho (2016) afirma que o papel educativo dos museus vem sendo definido de forma cada vez mais ampla com ênfase na relação com o visitante e na revisão constante das ações educativas realizadas no seu interior. Esta educação já foi entendida como entrega de 
informações para aprendizes. Para a autora, no entanto, a educação em museus é compreendida atualmente como a abertura de caminhos diversos para que o público selecione o que lhe interessa e não como uma instrução excessivamente erudita ou intelectual.

Para Valente, Cazelli e Alves (2005), no passado os visitantes se conformavam em contemplar o que era exposto. Atualmente busca-se a participação dos visitantes nas exposições e atividades realizadas ali. Isto se deu de forma contundente no século XX com o surgimento dos centros de ciência, quando houve a adoção de aparatos interativos, de atividades especiais, do uso de mediação humana nas visitas, da produção e uso de materiais educativos, entre outros.

Assim, alguns dos desafios impostos aos museus têm sido o desenvolvimento de estratégias que mantenham o entusiasmo do visitante real, cativo, e atraiam grupos tradicionalmente excluídos. Esta perspectiva de pensar os museus tem exigindo um equilíbrio entre os métodos tradicionais de comunicação realizados por esses espaços - processos comunicacionais de massa - e outros que possibilitem o intercâmbio de ideias entre as partes envolvidas - público e museu (VALENTE; CAZELLI; ALVES, 2005).

Hooper-Greenhill (1994) realizou um levantamento dos estudos no campo da educação e comunicação em museus e afirma que, no campo da educação em museus, abordagens positivistas, behavoristas e construtivistas vêm sendo adotadas, sendo que o desenvolvimento desta última vem se dando ao longo dos últimos anos. A autora defende a perspectiva construtivista para o desenvolvimento, entretanto, salienta que em determinadas situações, práticas identificadas com outras perspectivas podem fazer sentido neste espaço e que investigações devem ser feitas para avaliar a efetividade delas.

Pesquisas feitas para compreender como se dá a educação dentro dos museus apontam algumas particularidades em relação a este processo, as quais referem-se ao espaço físico, ao tempo em que os visitantes desfrutam da exposição e aos objetos de naturezas distintas que implicam diferentes formas de interação (VÄN-PRAET; POUCET, 1989; MARANDINO, 2009; MARTINS, 2011).

A questão do espaço físico está diretamente relacionada à exposição e diz respeito a liberdade de escolha do visitante que deve ser cativado durante o trajeto, sendo assim é importante que haja uma preparação para a recepção, organização, cenografia, conforto interno e avaliação do tipo de atividade a ser desenvolvida para evitar cansaço e dispersão nessa experiência. Outra questão levantada por pesquisas relacionadas às especificidades de um museu é a questão do 
tempo e também está diretamente relacionada a visita às exposições: este fator é muito importante para as estratégias comunicacionais nestes espaços, já que no museu ele é muito breve se compararmos com a escola, por exemplo. Por isso, ele deve ser pensado tanto no momento da concepção da exposição, quanto nas outras ações educativas desenvolvidas (MARANDINO, 2005).

Outra especificidade da educação em museus refere-se aos objetos. Figueroa (2012) destaca que os objetos são a razão de ser dos museus e não são simplesmente objetos comuns. Quando eles são selecionados para entrarem no museu tornam-se fonte primária para a pesquisa, informação, conhecimento e enriquecimento individual e coletivo (HORTA; GRUNBERG; MONTEIRO, 1999). Esses objetos podem ser de vários tipos - naturais, artificiais, morto, vivo, animal, botânico, original ou modelo (ALBERTI, 2005). Eles têm a função de comunicar, juntamente com outros recursos, conceitos e aspectos relativos à conservação, aos processos e fenômenos, importantes para uma determinada temática e um determinado público, ainda podem despertar admiração pela ciência e serem fonte de interatividade (VALENTE, 2005).

Para Carneiro (2009) os objetos são um dos recursos que podem ser utilizados para estimular e motivar o público durante a visita ou durante as outras ações educativas desenvolvidas nos museus, pois, segundo a autora, "é a motivação que guia a aprendizagem" (p. 46). A autora também menciona que os objetos podem estimular a memória e a afetividades do visitante, e este é um ponto importante para a aprendizagem. Seguindo essa mesma linha, Horta (1984) afirma que as experiências emocionais e afetivas são muito marcantes para o ser humano e o nível de percepção e motivação será tanto maior quanto maior for o estímulo, a autora defende que os objetos presentes nos museus, nos diversos tipos de atividades, podem interferir positivamente na experiência desse visitante no museu.

Percebe-se desse modo que os objetos são elementos centrais da educação em museus e além de estarem presentes nas coleções e nas exposições, são também utilizados em várias outras atividades educativas. Dentre os vários materiais educativos utilizados nos museus e jardins zoológicos, encontramos objetos que podem ser originais, réplicas ou modelos.

De acordo com a União Internacional de Diretores de Jardins Zoológicos (IUDZG, 1993), a partir do século XIX houve uma proliferação de zoológicos na Europa e sua principal vertente de atuação era de caráter taxonômico, isto é, preocupavam-se com a organização dos animais de acordo com suas características biológicas e morfológicas, tendo como resultado uma classificação. A preocupação ecológica surgiu no século XX com ênfase na biologia do 
comportamento e a partir do início do século XXI a maioria dos zoológicos se enquadra nesta visão "moderna" de desenvolver e apoiar pesquisas para o conhecimento da biodiversidade, tornando-se uma ferramenta importante na conservação e educação (GARCIA, 2006; BRITO, 2012; PIRES, 2016).

Ao longo de sua evolução, essas instituições foram ampliando sua missão e hoje seu principal objetivo se volta para a conservação da biodiversidade, de espécies ameaçadas de extinção, do estabelecimento de planos de manejo com propostas de preservação da biota e banco de genoma entre outros (BRITO, 2012). Garcia (2006), Mergulhão (1997) e Auricchio (1999), nos relatam que os zoológicos possuem um vasto campo de trabalho em diversas áreas do conhecimento por serem instituições multidisciplinares e que podem contribuir em diversos aspectos da educação científica e ambiental.

Com o passar do tempo e a modificação na filosofia de trabalho dos zoológicos com foco cada vez maior na educação, fez-se necessário o desenvolvimento de programas educativos, com o intuito de legitimar a existência desses espaços e de contribuir de maneira efetiva para a manutenção das espécies em seus ambientes naturais. Assim, os zoológicos modernos deixaram de operar apenas como uma "vitrine de animais" e adotam ações para o público e com o público. Portanto a educação é uma das principais missões dessas instituições a partir do momento em que suas ações a curto, médio e longo prazo, sustentam os esforços de conservação e investigação gerados nessas instituições (GARCIA, 2006).

Devido ao grande interesse do público nos zoológicos, esta instituição tornou-se de grande potencial para a disseminação de informações sobre fauna, considerando o animal um tema gerador de discussão sobre conservação ambiental e da relação ser humano-natureza (AURICCHIO, 1999). Alguns objetivos da educação nos zoológicos foram pontuados por Bazarra (1994 citada por GARCIA, 2006) como por exemplo, proporcionar conhecimentos científicos, reforçar atitudes positivas, apontar elementos para desenvolvimento de uma consciência ambiental, fortalecimento e enriquecimento cultural ao trabalhar temas relacionados a espécies nativas e exóticas; desenvolvimento da atitude científica no indivíduo; estímulo à criatividade e à imaginação; criação do sentimento de empatia, respeito e admiração à vida silvestre, entre outras.

Considerando o fascínio causado pelos animais aos seres humanos e que a curiosidade parece ser um pressuposto essencial para a apropriação de conhecimentos, exposições e outras atividades e produtos que proporcionam o contato com animais, podem contribuir como um 
importante elemento nos processos de alfabetização científica permitindo ao visitante vivenciar experiências significativas e agregar conceitos de diversas áreas de conhecimento. Assim, cada vez mais os zoológicos vêm sendo usados como apoio para as práticas pedagógicas (MARANDINO, 2001; GARCIA, 2006; AURICCHIO, 1999).

Diante das investigações desenvolvidas com foco no papel educativo dos museus, zoológicos, jardins botânicos etc, reconhecemos que estes espaços cumprem um papel fundamental na educação científica e continuada dos cidadãos e são relevantes como instituições capazes de enfrentar o desafio de comunicar ciência com base em informações originárias da pesquisa científica com diferentes e variados estímulos. Mas em que medida os materiais educativos produzidos por essas instituições contribuem com a AC?

Torna-se assim relevante investigar as várias ações educativas desenvolvidas pelos zoológicos analisando as potencialidades e os limites desses espaços para a alfabetização científica do cidadão. No caso deste trabalho, optamos por estudar especialmente o papel dos materiais educativos produzidos por um zoológico neste processo.

\section{3. MATERIAIS EDUCATIVOS EM MUSEUS}

\subsubsection{Materiais educativos: caracterização e uso pelos museus}

Ao analisar os materiais educativos dos museus, destaca-se a sua diversidade em termos de suportes, meios, estratégias e temas que abordam. Essa constatação torna difícil muitas vezes dizer o que é exatamente um "material educativo". No seu livro "A prática educativa, como ensinar", Antoni Zabala (1998) define materiais educativos como

“...todos aqueles instrumentos que proporcionam ao educador referências e critérios para tomar decisões tanto no planejamento como na intervenção direta no processo de ensino/aprendizagem e em sua avaliação" (ZABALA, 1998, p. 167).

O autor comenta que apesar de frequentemente serem menosprezados, esses materiais têm uma importância real e que muitas vezes definem a intervenção que será realizada pelo educador. A importância destes recursos é o de potencializar o processo educativo que ocorre e proporcionar o desenvolvimento de ideias, propostas e discussões que enriquecem tanto o trabalho do educador como o do educando. Cada material oferece potencialidades específicas e é 
importante ter clareza de qual momento eles podem ser úteis para promover um aprendizado mais efetivo no público que o utiliza.

Consideramos materiais educativos nesta pesquisa qualquer objeto, modelo, réplica, material impresso, imagem, apresentado em conjunto ou individualmente, de forma concreta ou virtual, em qualquer tipo de suporte ou mídia, com a finalidade de promover e/ou apoiar uma ação educativa nos museus.

Alguns autores destacam a importância dos materiais educativos como catalisadores de processos ativos de aprendizagem, promotores de alfabetização científica e cultural e como portadores de informações, além de serem motivadores e capazes de ajudar na concretização de conceitos (FALTAY, 2002; BOTAS; MOREIRA, 2013). Além disso, mencionam que eles podem ser mediadores na construção do conhecimento na medida em que o usuário pode manifestar, na interação com eles, espanto, curiosidade, rememoração, emoção e esses sentimentos podem ser articulados e interpretados em conjunto com outras experiências de sua vida.

Diante do exposto acima, percebemos que os materiais educativos, sob seus diversos suportes, podem apresentar contribuição em vários aspectos da $\mathrm{AC}$ - conceitual e cognitiva, impacto da ciência na sociedade, processo de produção do conhecimento e podem suscitar observação, questionamentos e reflexões que se caracterizam como indicativos importantes a serem averiguados frente ao nosso problema de pesquisa. Contudo, como aponta Rodrigues (2017), há limitações e especificidades no uso desses materiais nas atividades educativas dos museus, sendo necessário ampliar os estudos sobre esses artefatos.

Museus são locais propícios para motivar, desenvolver atividades e estabelecer diálogos e interações com seus variados públicos e entre os visitantes. Por esta razão, os museus dedicados a ciências naturais, como os zoológicos, os centros de ciência e os jardins botânicos, possuem grande valor pedagógico com enorme potencial de proporcionar momentos de deleite, lazer e aprendizado, ao tornar as informações mais acessíveis aos diferentes públicos. Há, hoje, um conjunto de evidências que destacam o compromisso cada vez maior dessas instituições com a educação ao longo da vida e, neste sentido, reforçam a relevância do trabalho dos educadores e dos setores educativos desses locais (MARANDINO et al, 2016).

Ao analisarmos algumas pesquisas sobre as práticas educativas cotidianas, percebemos que diversas ações cada vez mais estruturadas e abrangentes vêm sendo propostas pelos setores 
educativos dos museus e já existe um rol relativamente significativo de investigações que visam analisar seus pressupostos, seu potencial, avaliar seus impactos junto ao público (MARANDINO et al, 2016; STOCKLMAYER, 2002; FERREIRA; CARVALHO, 2015; STUDART, ALMEIDA; VALENTE, 2003).

Os museus de história natural, zoológicos, jardins botânicos, aquários e museus de ciências oferecem uma diversidade grande de ações educativas para o público com a intenção de envolver as pessoas no processo de ensino e aprendizagem, no intuito de promover uma relação de prazer com o conhecimento, buscando estimular a manipulação física, afetiva e cognitiva e procurando complementar, ajudar e problematizar a compreensão da ciência. Muitos autores vêm mencionando tipos diversificados de mediação entre o visitante e os conceitos apresentados nos museus, como visitas guiadas, materiais educativos, jogos entre outros (ELLIS, 2002; CAMPOS, 2013).

Autores como Chagas (1993) evidenciam a existência de uma tendência dentro dos museus em produzir e fornecer material de apoio pedagógico às escolas. Estes materiais podem ser desde recursos audiovisuais, coleções didáticas e textos didáticos até exposições itinerantes que visitam as escolas. Para além de apoio às escolas, os museus desenvolvem materiais para o trabalho junto aos diferentes públicos que recebe. No Brasil, podemos identificar diversos museus produzindo materiais educativos para seus públicos, tanto de apoio a professores quanto para o trabalho com famílias e pessoas com deficiência. O Ministério da Cultura, por meio do IBRAM produziu em 2011 uma publicação que nos traz, a partir de um levantamento feito pelo Cadastro Nacional de Museus, informações sobre atividades desenvolvidas pelos museus nacionais junto ao público visitante. Dente as atividades estão a produção de diversos tipos de materiais em suportes e mídias diversificadas, que podem ser disponibilizados on line ou fisicamente. Segundo a publicação, entre 17,1 e 43\% dos museus brasileiros declararam que produzem "material didático", somente atrás de "material de divulgação" (57,8\%). Além disso, também produzem: Catálogo do museu (18,3\%); Revista, boletim ou jornal impresso e eletrônico (25,8\%); Guia $(11,1 \%)$ e Anais $(3,5 \%)$. Os conteúdos dos materiais não foram especificados na publicação, mas podemos inferir que muitos dos materiais não denominados “didáticos” possam ser utilizados em ações educativas (MUSEUS EM NÚMEROS, 2011).

O educativo do Museu de Arqueologia e Etnologia da USP possui uma série de materiais educativos (kits de objetos arqueológicos, Guias temáticos para professores) voltados para a aproximação com as temáticas da arqueologia, etnologia e museologia. Por meio da 
participação nas formações, os professores podem retirar emprestado esses materiais e realizar diferentes trabalhos em suas instituições como forma de levar uma parte do Museu a outros locais. O Museu do Instituto Oceanográfico da USP disponibiliza acervo de animais marinhos conservados para professores e os utiliza também em suas atividades internas.

O Museu Goeldi (Belém, PA) possui uma coleção didática constituída de peças (animais originais conservados, material etnográfico, minerais e botânico) encontradas na região amazônica que representam as áreas de pesquisa do Museu Goeldi. Estes objetos são emprestados para os professores utilizarem em aulas, para alunos realizarem trabalhos escolares, feiras de ciências e exposições. O material ainda é utilizado em palestras, oficinas e cursos e nas ações educativas com os diversos públicos que frequentam o espaço, como crianças, estudantes, família e terceira idade. Além disso, este museu produz materiais impressos utilizados em ações junto a variados públicos. Campos (2009) analisou 26 materiais educativos com diversos objetivos de uso, produzidos pelo Museu Goeldi a partir do banco de dados do GEENF, que tratavam do conceito de biodiversidade. A autora concluiu que muitos destes materiais podem promover reflexões sobre esse tema. Alguns deles tratam dos conceitos de biodiversidade sob o ponto de vista da pesquisa discutindo a sua contribuição, da instituição e dos pesquisadores. Outros discutem a questão da conservação da biodiversidade apontando sua importância, o papel do ser humano neste processo e sua relação com as questões econômicas envolvidas.

Alguns museus fora do Brasil também têm uma produção considerável de materiais educativos. O Museu de la Ciência em Barcelona, Espanha, por exemplo, produziu uma série de livretos com atividades de apoio a todas as exposições que estão em cartaz no museu, cada um deles é acompanhado de um guia para o professor. O Museu da Nova Zelândia Te Papa Tongarewa produziu uma séria de áudio visuais acompanhados de um guia sobre suas exposições para serem utilizados tanto em atendimento a professores quanto em atividades com famílias. Museus norte-americanos como Museu de História Natural de Nova York, Instituto Smithsonian e Museu de História Natural de Los Angeles produziram uma série de guias de atividades para alunos e professores com conteúdo biológico sobre os animais de suas exposições, desenhos para colorir, informações sobre os animais "famosos" dos museus e folhas de atividades disponíveis on line para o público geral. O Museu de História Natural de Santa Bárbara, Califórnia disponibiliza kits com animais conservados, réplicas e modelos acompanhados de documentários, mapas e guias de atividades para empréstimo a professores. 
Com o intuito de identificar os materiais educativos produzidos por museus para a realização de possíveis análises e investigações sobre eles, o GEENF (Grupo de Estudos e Pesquisa em Educação Não Formal e Divulgação Científica da Faculdade de Educação da USP) desenvolveu um banco de dados sobre materiais educativos em museus coletados por seus membros em visitas a instituições e em função de suas pesquisas. O projeto "Acervo de Materiais Didáticoculturais/INCTTOX” teve início em 2009 e foi finalizado em 2016. Ao longo desses anos foi possível alimentar este banco de dados por meio da doação e aquisição de materiais de diferentes instituições de educação não formal - museus, centros de ciências, ONGs, grupos de pesquisa - que se encontram armazenados no acervo físico do GEENF na Faculdade de Educação da USP. O objetivo deste banco de dados foi identificar e organizar essas produções que podem ser analisadas sob diferentes pontos de vista, como por exemplo em relação aos conteúdos científicos, pedagógicos ou comunicacionais. Este acervo teve ainda a finalidade de inspirar novas práticas e promover a reflexão sobre parâmetros de produção de materiais didático-culturais em espaços não formais. Foram catalogados no banco 956 materiais entre jogos, objetos tridimensionais, kits e impressos e mais de 200 instituições envolvidas. Este banco de dados também traz a descrição dos materiais, público alvo e uma diversidade grande de funções: como divulgação, educativo, guias, comunicação etc, sendo que essas informações estão disponíveis para acesso on line em http://www.cienciaemrede.com.br/acervomaterialdidatico.

O setor educativo do Museu de Zoologia da USP, pelo qual a pesquisadora é responsável, produz diversos tipos de materiais para empréstimo para professores e trabalho com a família (kits de animais conservados, jogos tradicionais, impressos para realização de oficinas com os visitantes, maquetes acessíveis, animais conservados para toque, réplicas de fósseis, entre outros). Possui também uma coleção de materiais educativos fornecidos por museus e organizações culturais do mundo todo. No ano de 2016, com a colaboração de estagiários do Projeto Aprender com Cultura e Extensão da USP, foi possível organizar e catalogar este acervo. Pudemos identificar 973 materiais educativos no formato de cartões postais, cartilhas, catálogos, CDS, DVDs, kits, folders, jogos, guias, revistas e livros e mais de 60 instituições que produzem e se utilizam dos materiais nas mais diversas atividades.

Recentemente publicamos o livro "Educação em museus e os materiais educativos" com a finalidade de destacar e compartilhar experiências de produção, análise e investigação de materiais educativos nesses espaços. Este é mais um exemplo de como o tema vem ganhando relevância no meio educacional museal (MARANDINO et al, 2016). 
Como pudemos observar nos parágrafos anteriores com este breve, mas significativo, levantamento de museus de ciências que produzem e se utilizam de materiais educativos de diversas naturezas, estudar o potencial desses artefatos dos museus torna-se um tema relevante apesar de ainda pouco explorado nas investigações no âmbito da educação em museus. Assim, buscamos compreender quais tipos de materiais educativos são produzidos por museus de ciências, e, em especial, entender como esses materiais dialogam com a perspectiva da alfabetização científica e qual o impacto desses materiais no público.

\subsubsection{Os objetos biológicos como materiais educativos em museus e zoológicos}

Como já mencionamos nos capítulos anteriores deste trabalho, a educação que ocorre nos museus, jardins botânicos, aquários, jardins zoológicos entre outros espaços de educação não formal, apresenta especificidades relacionadas ao espaço físico, ao tempo em que os visitantes permanecem nas exposições e aos objetos de natureza distinta que permitem vários olhares e interações. Essas características permitem que os museus desenvolvam atividades com estratégias diversificadas - mediação, utilização de materiais educativos, utilização de folhetos e cartilhas, jogos, bate-papo, visita de especialistas a escolas, oficinas entre outros (MARANDINO, 2002, 2009).

Os objetos biológicos são amplamente utilizados nas ações educativas em museus, incluindo os zoológicos. Garcia (2003) realizou levantamento junto a zoológicos brasileiros e constatou que animais taxidermizados, partes conservadas de animais e modelos são bastante usados nesses locais. Neste trabalho, a autora enviou 80 questionários para educadores de zoológicos brasileiros com questões relacionadas à caracterização da instituição, às atividades educativas praticadas e ao material utilizado. A autora obteve 25 respostas que mostraram que essas instituições realizam diversas atividades com os materiais: aulas, palestras, exposições, empréstimos para a comunidades, professores e estudantes. Sobre o impacto do uso dos materiais a partir do depoimento dos educadores pesquisados, concluiu que esse recurso auxilia no processo de ensino e aprendizagem de diversos conteúdos (biologia, ecologia e educação ambiental) nos programas educativos dos zoológicos. No entanto, também indica que esses materiais apresentam limitações seja na preparação, na manutenção e no armazenamento das peças.

Diversos outros autores analisam o trabalho com objetos em zoológicos e outros espaços de educação não formal (REEVE, 1998; GARCIA, 2006; CÂNDIDO, 2008; FALCÃO, 2007; CAMPOS, MARANDINO, 2010; MARANDINO et al, 2016; VASCONCELOS, 2014). Esses 
trabalhos indicam que os objetos permitem várias possibilidades de ações educativas nesses espaços, como por exemplo, divulgação de conceitos científicos, despertar o interesse do público, combinar atividades lúdicas e cognitivas, oferecer estímulos quando são manuseados e contemplados, evidenciar fenômenos, motivar e estimular a curiosidade criando conexões entre eles e a experiência do visitante. Além disso, podem ser utilizados com várias faixas etárias e públicos diversificados.

Alguns trabalhos analisam o potencial dos objetos no processo de ensino e aprendizagem, no contexto da exposição. Mesmo não sendo este o contexto dessa pesquisa, destacamos o trabalho de Leinhardt e Crowley (2001) já que o foco é a análise do potencial dos objetos em si para o processo de aprendizagem. Segundo esses autores, a resposta emocional dos visitantes é um importante aspecto relevante do trabalho com os objetos. Eles relacionam algumas características dos objetos como importantes para o trabalho com o público e que os torna peças únicas para discussão e elaboração de ideias, são elas: resolução e densidade de informação, pois os objetos mantém essas características já que oferecem a oportunidade "ao vivo" de observação de suas peculiaridades; escala, já que eles se apresentam em escala real; autenticidade, pois possibilitam o compartilhamento de sensações e têm o potencial de conectar o público com o fato que está sendo observado ou proposto; e o valor, referindo-se ao valor econômico e cultural dos objetos. Portanto, os objetos, especialmente quando acompanhados de algum instrumento de mediação, têm o potencial de facilitar o acesso do visitante a novos conhecimentos, inclusive o científico, pois provoca a curiosidade e o desejo de conhecer (WAGENSBERG, 2005; JAKOBSSON; DAVIDSSON, 2012; NASCIMENTO; VENTURA, 2005).

\subsubsection{Estudos sobre o potencial de materiais educativos em museus}

Como vimos, para além das atividades de atendimento ao público, por meio de visitas mediadas, cursos, ciclos de palestras entre outros, os setores educativos dos museus produzem materiais educativos. Dentre os materiais educativos produzidos, encontram-se réplicas ou objetos autênticos para educação e deleite dos visitantes, que, na maioria das vezes, podem ser tocados e manipulados. Este tipo de material pode fornecer informações preciosas sobre conteúdos e procedimentos científicos. Existem, ainda, kits ou conjunto de peças que reúnem diferentes tipos de materiais e que podem ser utilizados no próprio museu ou emprestados ao público. Alguns museus disponibilizam esses materiais online em seus sites ou, ainda, os comercializam nas "lojinhas". Outro material frequente nos museus são os modelos que possibilitam uma 
visualização de detalhes fundamentais para compreensão de conceitos e até métodos de preparação de materiais originais (MARANDINO et al, 2009, 2016).

Apesar de, reconhecidamente, os materiais educativos nos museus apresentarem um potencial educativo importante e serem produzidos em grande quantidade, as pesquisas para analisar e avaliar os impactos desses materiais são ainda incipientes. Como vimos, alguns trabalhos reforçam o seu potencial em proporcionar aprendizagens e como instrumentos de divulgação, além de sua capacidade de motivar a investigação, levando o público a criar novos sentidos e, também, outros materiais. Contudo existem algumas investigações que analisam a produção e o uso de materiais educativos de museus de ciência no Brasil e em alguns países da América do Sul que iremos apresentar a seguir.

Santos-Gouw, Pereira e Contreiras (2011), estudaram os materiais educativos voltados ao público escolar (professores e alunos) relativos a exposições sobre Darwin veiculadas durante a comemoração dos 200 anos do nascimento de Charles Darwin e 150 anos de publicação do seu livro "A Origem das Espécies". Os critérios para a escolha das instituições que teriam os materiais analisados foram: a exposição ter como foco a temática Darwin; possuir site na Internet e disponibilizar material educativo no site on-line. Foram selecionadas 4 exposições: Darwin Big Idea, Big Exhibition, do Museu de História Natural de Londres; Darwin, do Museu Americano de História Natural; A evolução de Darwin, da Fundação Calouste Gulbenkian, Portugal e Exposição Darwin, do Instituto Sangari. Os autores avaliaram a oferta de ações educativas por parte dos museus estudados sob a perspectiva do potencial que esses materiais poderiam ter na preparação dos alunos para a visita, no aproveitamento da própria visita e no pós-visita. O trabalho conclui que os materiais educativos disponíveis constituem bons instrumentos de divulgação científica, que podem oferecer recursos significativos para a melhoria na qualidade das visitas às exposições e na extensão delas através de atividades pré e pós-museu. Segundo os autores, a disponibilização deste tipo de recurso possibilita que o professor se aproxime do museu e de sua temática e oferece oportunidades concretas para o desenvolvimento de atividades pedagógicas com seus alunos.

Elazari (2000), discute a função dos kits didáticos produzidos pelo Museu de Arqueologia e Etnologia da USP/MAE, que foram idealizados para serem usados em atividades educativas com o público escolar. A autora destaca os aspectos relacionado às sensações e sentimentos que os materiais despertam: 
"Por serem concretos e visíveis, os objetos tanto envolvem como desenvolvem nossos sentidos quando olhamos, tocamos, cheiramos, ouvimos e mesmo os degustamos. E, podendo manuseá-los, os sentimos mais plenamente" (ELAZARI, 2000, p. 351.)

Para ela, os materiais possuem a capacidade de motivar a investigação, a análise e a pesquisa por outras informações, o que inclusive pode levar o público a criar novos sentidos e materiais. Ela discute que a capacidade de "ler os objetos" (p. 351) os transforma em um poderoso material educativo e considera que esses recursos criados pelos museus fazem parte do princípio de que, cabe a esta instituição propiciar oportunidades e experiências inovadoras ao público, de modo a alargar o espaço de livre questionamento, criando condições para o exercício das potencialidades do indivíduo.

Vasconcelos (2014) também analisa outro material educativo produzido pelo Museu de Arqueologia e Etnologia da USP/MAE - os kits educativos formados por 4 maquetes táteis e objetos arqueológicos focando a arqueologia brasileira e destinados ao público escolar. O autor menciona que o material foi produzido com o objetivo de socializar o conhecimento arqueológico, provocar estímulo para o desenvolvimento de habilidades quando o público vivencia experiências concretas; além disso desperta o interesse dos estudantes por meio de manipulação de suportes diversificados. Para o autor, o material possui um apelo lúdico que permite uma atitude favorável em relação ao processo de aprendizagem que possibilita que o usuário relacione o mundo que o cerca a partir de elementos que o compõem, além de proporcionar um aprendizado agradável e significativo.

Outra pesquisa realizada no herbário da Universidade Estadual de Ponta Grossa (PONTAROLO; CAPUANO, 2011), trabalhou com materiais botânicos secos, identificando plantas tóxicas, medicinais, invasoras e melíferas. Os autores concluíram que a utilização do material teve um resultado positivo em relação às visitas e palestras para alunos do ensino médio, que foram despertados para a pesquisa em botânica e a conservação da natureza.

Campos e Marandino (2010) no artigo que apresentou a investigação das diferentes abordagens de biodiversidade nos materiais didático-culturais produzidos pelo Museu Paraense Emilio Goeldi, afirmam que esses materiais colocam o público que os utiliza em contato com o acervo do Museu, aumentando o conhecimento das espécies de seu entorno e criando novas formas de percepção do ambiente. Os aspectos estéticos e recreativos dos materiais trazem uma dimensão afetiva que pode gerar nos visitantes um interesse maior na biodiversidade. As autoras 
concluem que os materiais produzidos trazem contribuições para a compreensão do público sobre algumas dimensões da biodiversidade.

Braunstein, Spadoni e Farias (2013) apresentaram o resultado de uma investigação sobre a relevância e o uso dos kits didáticos "Vertebrados Fósseis do Rio Grande do Sul" do Museu de Ciências Naturais da Fundação Zoobotânica do Rio Grande do Sul. O material é composto por 10 réplicas de fósseis e fichas com informações sobre os organismos fossilizados que são emprestados para os professores levaram para a escola. O objetivo dos kits é discutir aspectos da evolução biológica através das réplicas dos fósseis. Segundo os autores, o uso de réplicas e kit didáticos para o ensino de paleontologia é recorrente, sendo apresentado como uma importante ferramenta para o ensino. Para a Paleontologia, antes do trabalho teórico com conceitos dessa área de conhecimento, seria muito útil trabalhar com modelos tangíveis. Portanto, a existência dos fósseis se torna uma grande riqueza desde que esses possam ver vistos e preferencialmente manipulados pelos estudantes, dando assim concretude para seus saberes teóricos e facilitador da aprendizagem. Em relação à aceitação do kit pelos alunos na pesquisa citada, os autores apontam que esta foi positiva e que foram desenvolvidas atividades mais simples, que podem ser realizadas por e para qualquer nível de ensino, como exposição, manipulação e cópia dos desenhos presentes nas fichas informativas. Por outro lado, nos relatos das atividades mais elaboradas, o kit se mostrou como um excelente instrumento de mediação da aprendizagem e interdisciplinaridade.

Cherutti, Mathias e Garcia (2011) investigaram a aplicação da sacola ecológica como recurso didático de ensino-aprendizagem durante a visita monitorada no Zôo de Sorocaba, mesma instituição analisada nesta pesquisa. Este material foi produzido com o objetivo de preparar o professor para a visita. Este participa de uma reunião na qual são explicitadas todas as etapas da atividade e lhes é oferecida a sacola que apresenta propostas de atividades a serem desenvolvidas com os alunos preparando-os para a visita. As autoras concluíram que a sacola ecológica mostrou ser um recurso de ensino-aprendizagem significativo para trabalhar em espaços não formais de educação, sendo imprescindível na abordagem de conceitos preparatórios de educação ambiental para visita monitorada no zoológico, no entanto, comentaram que é necessário haver uma preparação prévia na sala de aula pois o material não dá conta de todos os conceitos trabalhados durante a visita. Apesar desse fato, segundo as autoras, a utilização da sacola ecológica, atrelada às atividades escolares, é um importante recurso didático na assimilação dos conceitos apresentados. 
Rubio (2000), profissional do Museo Nacional de Machado de Castro desenvolveu um material educativo denominado "Maleta Pedagógica" com o objetivo de preparar os alunos para a visita ao museu. A instituição é um museu de arte da cidade de Coimbra (Portugal), inaugurado em 1913 e que possui uma vasta coleção de temática religiosa. O material consta de fichas de orientação e imagens das obras do museu e da história da arte, gravações musicais e a planta do museu. No trabalho anterior e posterior à produção do material, a autora realizou uma investigação sobre o conhecimento dos visitantes sobre o acervo do museu. A pesquisa anterior à utilização do mesmo, mostrou uma grande desinformação sobre as obras do museu. A pesquisa realizada após a utilização do material e visita ao museu, concluiu que os estudantes foram estimulados pelo material a pesquisar e conversar sobre as obras vistas durante a visita, criando uma visão favorável em relação ao museu em seu público escolar.

Cascante (2010) na sua dissertação de mestrado, tinha como objetivo produzir um material educativo denominado de "Valise didática" para o Museo Arqueológico Regional Altos de Chavón, na República Dominicana. Este museu documenta a herança indígena na região e o material educativo foi concebido para ser emprestado para a comunidade. A valise é composta por objetos do acervo do museu, fotografias, CDs e material bibliográfico. Segundo o autor, alguns dos objetivos da produção deste material foi aproximar os visitantes do conteúdo do museu, promover a valorização da arqueologia dominicana, tratar de assuntos que fomentam o desenvolvimento de habilidades e procedimentos cognitivos e fomentar a análise e conexão com outros temas de forma lúdica e interativa. Para ele, este tipo de material tem como propósito aproximar o público do museu, facilitar o acesso deste ao acervo apresentado na exposição, dar a conhecer os assuntos tratados no museu a partir de sua utilização e contribuir para os programas educativos das redes oficiais de ensino. O recurso também pode gerar um impacto duradouro nos usuários já que permite que eles desenvolvam as atividades propostas tocando, desenhando, associando ideias e fazendo conexões com sua vida atual.

Rodrigues (2017) desenvolveu, produziu, aplicou e analisou um roteiro educativo de visitação da Trilha da Nascente do Jardim Botânico de São Paulo, sob a perspectiva da AC em museus. Em seu trabalho, a autora verificou que o roteiro possui o potencial de subsidiar a visita de famílias a exposições promovendo a $\mathrm{AC}$ ao serem planejados com este objetivo. Segundo a autora, o roteiro potencializa este processo principalmente em relação às dimensões afetivas, estéticas e científicas. A autora salienta que o roteiro possui uma limitação em relação aos aspectos institucionais e de interface social da AC. 
A partir dos trabalhos apontados, identifica-se a existência de uma verdadeira produção e utilização de materiais educativos nos museus, sendo esta uma prática bastante difundida nesses espaços. Essas pesquisas nos mostram o público principal a que se destinam os materiais educativos produzidos nos museus - público escolar, professores e alunos. Esses materiais são utilizados com esse público tanto no ambiente museológico como são emprestados para que os professores os utilizem em sala de aula ou para que os alunos apresentem trabalhos escolares, além de serem usados em cursos e palestras com professores, no próprio museu. Poucos são ainda os trabalhos que analisam os materiais educativos junto ao público geral dos museus, como o caso de Rodrigues (2017).

As pesquisas descritas se dedicaram a compreender o potencial desses materiais nesses espaços e muitas delas concluíram que eles possibilitam a construção de conceitos, despertam o interesse e motivam o público. Alguns autores citaram também que os objetos que formam esses materiais podem estimular sensações e lembranças importantes para despertar a afetividade do visitante, fator importante para a aprendizagem. Vimos que alguns dos trabalhos citados fizeram levantamentos de ações e materiais educativos e como esses materiais impactaram o público. Percebemos que, na maioria dos trabalhos, as análises são quase sempre positivas e, raramente, vê-se a discussão sobre os limites desses materiais e os problemas que podem existir, como por exemplo, a reposição, os custos, a manutenção entre outros. Rodrigues (2017), pondera, contudo, alguns cuidados na produção de materiais educativos nos museus e destaca que o público pode muitas vezes utilizá-los de formas diferentes das previstas pelos idealizadores, fazendo uso de forma pontual ou mesmo tendo a liberdade de fruição da visita inibida por eles.

Ao nosso ver, é de suma importância encarar o desafio de refletir, analisar e planejar a produção de materiais educativos que os museus têm produzido pois eles podem ter o potencial de contribuir para alguns aspectos da $\mathrm{AC}$, como vimos nos trabalhos acima. Potencialmente possibilitando o domínio das formas atuais de linguagem e dos princípios científicos e tecnológicos promovendo a capacidade de lidar com o conhecimento científico com responsabilidade social e de forma crítica.

Assim sendo, esta investigação será importante para o aprofundamento do papel, impacto e limites dos materiais educativos para a melhoria da alfabetização do público que os utiliza. 
4. METODOLOGIA

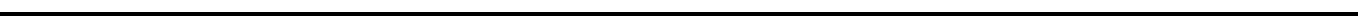


$\mathrm{Na}$ literatura, vários autores afirmam que os espaços não formais de educação, contribuem para a AC de seus visitantes (CERATI, 2014; CAZELLI, 1992; MINGUES, 2014; BYBEE, 1995; HENRIKSEN; FROYLAND, 2000). As diversas tipologias de museus em relação aos seus acervos e conformações institucionais, comportam um grande número de ações educativas voltadas para diversos públicos (MARTINS, 2011). No entanto, ainda são poucos os trabalhos empíricos que analisam os materiais educativos nesses espaços (CERATI, 2014; MARANDINO et al, 2016). Neste sentido torna-se fundamental investigar os materiais produzidos em tais espaços e seu potencial como promotor da alfabetização científica.

Neste capítulo apresentaremos as metodologias utilizadas para coleta e análise de dados para a pesquisa dos materiais educativos no Zôo de Sorocaba. Bem como uma breve discussão dos métodos adotados neste trabalho.

As metodologias quantitativa e qualitativa são frequentemente retratadas como paradigmas distintos e incompatíveis em investigação educacional (MORAIS; NEVES, 2007). As diferentes formas de combinar metodologias recorrendo a noções como as de "triangulação", "métodos mistos", "modelos mistos" ou "métodos múltiplos" têm sido reconhecidas ultimamente como muito úteis porque abordam diferentes tipos de questões. Estas discussões refletem a necessidade de usar metodologias oriundas de diferentes tradições (métodos qualitativos e quantitativos) numa mesma investigação e o interesse crescente no que se refere à diversidade metodológica e abertura, após muito tempo em que prevaleceram as "guerras de paradigmas" (DUARTE, 2009).

A "triangulação" tem sido o termo mais utilizado na literatura, sendo reconhecida por vários autores como um conceito central na integração metodológica. Este conceito constitui uma das formas de combinar vários métodos qualitativos entre si e de articular métodos quantitativos e qualitativos. A aplicação de vários métodos e instrumentos de coleta e análise de dados com a intenção de confirmar e checar as informações, confere rigor à pesquisa, melhora a validade dos resultados e conquista a confiança dos participantes. O pesquisador tem a possibilidade de melhorar a precisão de suas avaliações, utilizando metodologias distintas, coletando dados de diferentes formas, analisando tais dados por métodos distintos ou até mesmo, empregando-se diferentes pesquisas para estudo de um mesmo fenômeno. Diversos autores argumentam que uma hipótese testada com diferentes métodos pode ser considerada mais válida do que uma hipótese testada com um único método. (FERNANDES, 2015; GUTBERLET; 
PONTUSCHKA, 2010; PATTON, 2001; DUARTE, 2009; AZEVEDO et al, 2013; MORAIS; NEVES, 2007).

Denzin (1998, citado por DUARTE, 2009) afirma que, em face das "fraquezas" e das "virtudes" de cada método, a "triangulação" consiste num processo de colocar cada método em confronto com outro para a maximização da sua validade tendo como referência o mesmo problema de investigação. Neste sentido, o principal objetivo da integração de métodos seria a convergência de resultados de investigação, resultados que seriam válidos se conduzissem às mesmas conclusões.

Este trabalho utiliza várias metodologias que nos permitiram um aprofundamento e um distanciamento para sua elaboração a fim de fortalecer a dar confiabilidade aos resultados apresentados. Portanto, a triangulação dos dados mostra-se neste caso, uma estratégia eficiente para este objetivo. Neste trabalho serão comparados os resultados das entrevistas com as idealizadoras e gestoras dos materiais, publicações feitas por pessoas envolvidas com os materiais educativos, as observações dos materiais educativos (kits ecológicos e mochila de curiosidades) realizadas por nós, documentos presentes nos arquivos do Zôo de Sorocaba e os diálogos dos estudantes durante o uso do material "mochila de curiosidades", sob a luz dos indicadores de AC.

Os diferentes paradigmas que permeiam os métodos qualitativos e quantitativos traduzem diferentes formas de "olhar a realidade" - ou seja, diferentes formas de trabalhar as questões colocadas. Chizzotti (2003) e Martins (2004), defendem que a coleta e análise pelo método qualitativo, pressupõem a análise dos microprocessos sociais envolvidos na questão de pesquisa, pois realiza-se um exame intensivo dos dados tanto em amplitude quanto em profundidade possibilitando a criação e a atribuição de significados às coisas e às pessoas nas interações sociais. A metodologia qualitativa privilegia a informação interpretativa, o sujeito traz indagações a partir de suas concepções de mundo e posiciona-se a partir de um contexto histórico (MARANDINO et al, 2009).

Entendemos que esta abordagem é eficaz para este tipo de investigação, pois segundo Bogdan e Biklen (1994), permite a compreensão dos processos educacionais envolvidos na compreensão do fenômeno muito mais do que somente os produtos finais. No nosso caso, foi importante compreendermos como foi o processo de concepção, produção e utilização de tais materiais, a partir dos dados qualitativos, para compreendermos como eles se articulam tanto 
com os objetivos do Zôo de Sorocaba quanto com os indicadores de AC adotados neste trabalho para investigarmos nossa hipótese da contribuição desses materiais para a AC.

Há autores que ressaltam como barreira à sua utilização a subjetividade, devido à proximidade do pesquisador e do pesquisado, já que isso poderia levar a falta de rigor da pesquisa. No entanto, Gutberlet e Pontuschka (2010) afirmam ainda, que é justamente o envolvimento reflexivo entre pesquisador e objeto que promove um olhar diferenciado da questão em estudo. A profundidade de análise, o envolvimento e a participação do pesquisador é que permitem um aprofundamento e intensificação da análise de fenômenos complexos e inesperados que envolvem experiências, relatos e pensamentos de seres humanos com seu mundo (GONÇALVES, 2007; FISCHER, 2006).

Além do método qualitativo, também empregamos um olhar quantitativo, com estatística simples, sobre as observações dos materiais educativos realizadas. Essa análise contribuiu para maior amplitude e precisão de resultados, bem como para uma conclusão mais aprofundada sobre a contribuição desses materiais no processo da alfabetização científica do público.

Os métodos qualitativos e quantitativos podem combinar-se de diferentes formas numa mesma investigação. Os diferentes métodos podem ser utilizados ao longo da investigação; podem caminhar simultaneamente ou consecutivamente; a combinação pode ocorrer na análise de dados e na articulação de resultados (DUARTE, 2009).

Neste trabalho adotamos o modelo consecutivo, coletando e analisando os dados das entrevistas, documentos e interação do público com técnicas qualitativas. Segundo Flick, (2005, citado por DUARTE, 2009), os dados de entrevistas quase não permitem uma análise quantitativa, a não ser que se utilizem métodos complementares a elas. Para a análise dos indicadores de AC nas observações dos materiais e na interação com o público, utilizamos a metodologia quantitativa. Todos os dados foram analisados em conjunto para alcançarmos os objetivos já descritos.

Para o desenvolvimento desta pesquisa serão estudados os materiais educativos utilizados em duas atividades (Visita Orientada e Empréstimo de Acervo Educativo) do Parque Zoológico Municipal Quinzinho de Barros, também conhecido como Zôo de Sorocaba - maneira pela qual iremos nos referir a ele neste trabalho, na cidade de Sorocaba, interior de São Paulo. A escolha deste espaço se deu por este possuir um Centro de Educação Ambiental desde 1979, responsável por produzir uma série de ações e materiais para um amplo público (GARCIA, 2006). 
É importante destacar que parte dos dados que serão usados nesta pesquisa foram coletados por Garcia (2006) em sua dissertação de mestrado desenvolvida no Zôo de Sorocaba. Nesta investigação a autora, membro do Grupo de Estudo e Pesquisa em Educação Não Formal e Divulgação da Ciência da Faculdade de Educação da Universidade de São Paulo (GEENF), estudou o processo de aprendizagem do público escolar durante a visita orientada, uma atividade que utiliza um dos materiais educativos produzidos pelo zoológico - mochila de curiosidades. Há, contudo, um outro conjunto de dados que foi coletado por nós.

\subsection{COLETA DE DADOS}

Esta pesquisa tem como objetivo investigar a concepção, produção e utilização dos materiais educativos do Zôo de Sorocaba com a intenção de confirmarmos nossa hipótese de seu potencial para a AC do público. Antes de iniciar a coleta de dados, fizemos visitas exploratórias para conhecer os materiais e as pessoas responsáveis por eles, quando foram solicitadas as autorizações necessárias para o desenvolvimento da pesquisa na instituição (ANEXOA).

\subsubsection{Instrumentos e procedimentos de coleta de dados}

Para este estudo buscou-se recolher os dados que auxiliassem na compreensão das intenções das idealizadoras e gestoras a partir de entrevista semiestruturada, observação dos materiais educativos pela pesquisadora, análise de documentos e interação do público com os materiais. Em todos os casos, o foco é identificar o potencial desses materiais para o processo de AC. A seguir indicamos as técnicas de coleta dos dados da pesquisa.

A apresentação dos instrumentos e procedimentos de coleta será feita em dois blocos:
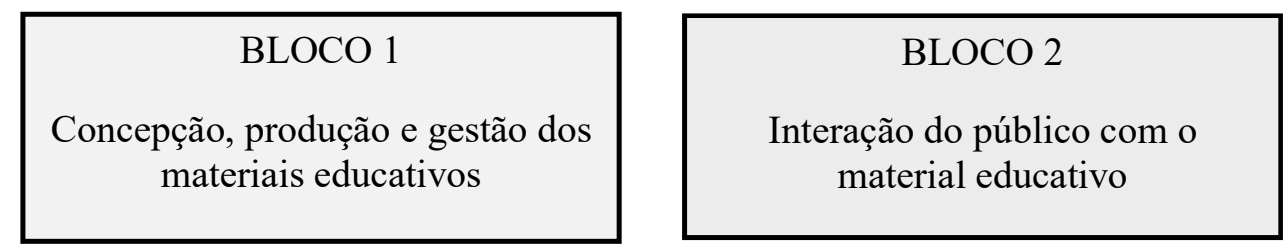

\subsubsection{Concepção, produção e gestão dos materiais educativos}

\section{a) Entrevista semiestruturada}

Para entender o processo de concepção e gerenciamento dos materiais educativos, bem como os objetivos norteadores de sua produção, foram realizadas entrevistas semiestruturadas com três profissionais que fazem parte da cadeia concepção-produção-gestão dos materiais 
educativos. Foram entrevistadas: a educadora que concebeu os materiais (que já não é mais funcionária do Zôo de Sorocaba), a educadora atual responsável pela atualização e gestão dos materiais e a profissional responsável pelo agendamento dos empréstimos para o público. Esta última entrevista foi utilizada para compreendermos como se dá a operacionalização dos empréstimos, portanto não será analisada do ponto de vista dos indicadores de AC. As questões que orientaram as entrevistas semiestruturadas com os responsáveis pela concepção e gerenciamento dos materiais educativos do Parque Zoológico Municipal Quinzinho de Barros estão no Apêndice A deste trabalho.

A entrevista semiestruturada é um dos modelos mais utilizados, guiada pelo roteiro de questões, o qual permite uma organização flexível e ampliação dos questionamentos à medida que as informações vão sendo fornecidas pelo entrevistado (FUJISAWA, 2000). Para Boni e Quaresma (2005), esta técnica tem como vantagem sua elasticidade quanto à duração, o que permite maior aprofundamento em determinados tópicos. A proximidade entre entrevistado e entrevistador permite maior espontaneidade das respostas e permite ao entrevistador tocar em assuntos mais complexos e delicados, quanto maior a proximidade entre esses atores, maior o vínculo criado e maior a possibilidade de compreendermos os significados afetivos e valorativos dos entrevistados. Neste tipo de técnica podem surgir questões nas quais o entrevistador não tenha pensado que podem ser bastante úteis na pesquisa.

Os dados obtidos foram registrados por meio de gravações diretas. Esta técnica tem a vantagem de ampliar o poder de registro e captação de elementos de comunicação de extrema importância, pausas de reflexão, dúvidas ou entonação da voz, aprimorando a compreensão da narrativa (SCHRAIBER, 1995). Autores como Patton (2001) e Rojas (1999) concordam com esta indicação, pois o gravador preserva o conteúdo original e aumenta o rigor dos dados coletados. Registra palavras, silêncios, vacilações e mudanças no tom de voz, além de permitir maior atenção ao entrevistado, captura as expressões verbais no momento em que elas são geradas para posteriormente serem transcritas.

As entrevistas foram realizadas nos dias 17 e 28 de outubro de 2014, foram gravadas e transcritas por nós entre dezembro de 2014 e março de 2015. Ouvimos várias vezes as entrevistas e procuramos apresentá-las da forma mais fidedigna possível mantendo pausas, risos, expressões, mudanças de entonação de voz e outras variações ocorridas na entrevista, como sugere Belei et al (2008). As entrevistas foram revistas e aprovadas pelas entrevistadas 
(ANEXO B). Eliminamos erros gramaticais e de expressões para evitar constrangimentos das entrevistadas (LAGE, 2001).

\section{b) Observação}

Para a descrição, caracterização e análise dos materiais educativos foram realizadas observações a partir de um roteiro construído com base nos indicadores e atributos descritos neste trabalho (ROCHA, 2016; CERATI, 2014; OLIVEIRA, 2016). As observações foram planejadas depois de visita exploratória ao zoológico no primeiro semestre de 2014.

A observação também é considerada uma coleta de dados para conseguir informações sobre determinados aspectos da realidade, ela possibilita um contato mais direto com o objeto pesquisado (BONI; QUARESMA, 2005). Observar é um processo e possui elementos para seu desenrolar: o objeto observado, o sujeito, as condições, os meios e o sistema de conhecimentos, a partir dos quais se formula o objetivo da observação (BELEI et al, 2008). As observações propiciam a imersão no universo pesquisado e permitem:

- Caracterizar e descrever os materiais,

- Compreender se e como os indicadores e atributos de AC estão expressos,

- Identificar e entender como os elementos que compõem os materiais educativos estão apresentados e sua articulação com os indicadores e atributos de AC.

Uma observação controlada e sistemática se torna um instrumento fidedigno de investigação científica. Ela se concretiza com um planejamento correto do trabalho e preparação prévia do pesquisador (LÜDKE; ANDRÉ, 1986). Diz-se que uma observação é fidedigna quando o observador é preciso e seus registros são confiáveis. Não basta apenas colocar-se próximo ao objeto de estudo e olhá-lo. Deve-se olhar e registrar (BELEI et al, 2008).

As observações foram feitas em três visitas ao Zôo de Sorocaba entre setembro e novembro de 2014. Construímos uma tabela para os registros que apresenta os itens abaixo, e que foram estabelecidos por nós a partir da análise prévia dos materiais e de acordo com os indicadores e atributos de $\mathrm{AC}$ : nome do kit, conteúdo/conceitos, indicação de quando usar, indicação de como usar, itens que compõem o kit, descrição, autoria. O protocolo para registro das observações dos materiais educativos do Parque Zoológico Municipal Quinzinho de Barros está no Apêndice B. 
Nome do kit: refere-se ao que está expresso na embalagem que o abriga e no manual do professor correspondente.

Conteúdo/conceitos: está relacionado com os tópicos tratados nos manuais e com assuntos de que tratam os kits.

Indicação de quando usar: diz respeito a sugestões do local ou situação de uso.

Indicação de como usar: apresenta sugestões de atividades que possam ser feitas com o kit. Itens: são os objetos presentes no kit.

Autoria: refere-se a quem produziu o material.

Indicadores e atributos de AC: referem-se aos indicadores de AC de Rocha (2016), Oliveira (2016) e Cerati (2014) que foram identificados nos materiais na análise.

Os materiais foram fotografados com base em um protocolo construído após a exploração dos materiais (Apêndice C). A imagem vem sendo há muito tempo uma ferramenta para registrar o movimento, ou seja, as ações e comportamentos. Torna-se, assim, um instrumento para captar o objeto de estudo, pois reduz questões da seletividade do pesquisador e configura a reprodutividade e estabilidade do estudo. A principal vantagem deste método é que outros pesquisadores ou colaboradores também podem fazer uso do material coletado. Torna-se possível analisar todo o material de pesquisa e manter a neutralidade dos dados (REYNA, 1997; HEIVEIL, 1984; SCAPPATICCI et al, 2004).

\section{c) Pesquisa documental}

Segundo Lüdke e André (1986) a pesquisa documental é pouco utilizada nas áreas das ciências sociais e educação. $\mathrm{O}$ uso dos documentos deve ser apreciado e valorizado, pois a riqueza de informações que podemos extrair possibilita ampliar o entendimento do objeto de estudo. Outra justificativa para o uso de documentos em pesquisa é que ele favorece a compreensão da evolução dos processos (SÁ-SILVA et al, 2009). No caso deste estudo, os processos envolvidos na idealização e produção dos materiais são importantes para a identificação dos indicadores e para a compreensão de como eles se articulam com os objetivos do Zôo de Sorocaba e dos personagens envolvidos. Além disso, os documentos produzidos complementam nossas observações dos materiais e as interações do público com eles (LÜDKE; ANDRÉ, 1986).

Nossa pesquisa documental utilizou-se de documentos contemporâneos e retrospectivos considerados cientificamente autênticos (CAMARGO, 2015). O Zôo de Sorocaba tem como norma relatar anualmente as atividades que ocorrem na instituição, para a pesquisa documental 
consultamos os Relatórios Anuais feitos pela equipe do Centro de Educação Ambiental entre 1993 e 2010. A coleta dos dados foi realizada em novembro e dezembro de 2015.

Outra fonte que consideramos como documento neste trabalho são as publicações das componentes da equipe envolvida com os materiais em diferentes oportunidades e que tratam de vários aspectos relacionados a eles. São elas: Belinassi e Mergulhão, 2006; Cherutti; Mathias e Garcia, 2011; Garcia e Marandino, 2006; Garcia, 2006. Estes trabalhos tiveram duas funções nesta pesquisa: fonte documental e referência teórica.

O site do Zoológico de Sorocaba também foi outra fonte documental pesquisada, pois apresenta as atividades desenvolvidas, os materiais educativos, objetivos e informações gerais sobre a instituição.

\subsubsection{Interação do público escolar com os materiais educativos}

\section{a) Mochila de curiosidades}

Como dito anteriormente, este trabalho se utilizou dos dados coletados por Garcia (2006) no seu trabalho de mestrado durante uma visita orientada utilizando os objetos biológicos da "mochila de curiosidades" como estímulo à discussão.

O público visitante escolhido pela pesquisadora foram 12 alunos de primeira série do ensino fundamental de uma escola pública de Sorocaba, com idade de 7 anos. Essa escolha ocorreu após a análise dos Relatórios Anuais do Centro de Educação do Zôo Sorocaba, no período de 1993 a 2003 que apontou ser este o universo amostral de maior frequência nos registros de visitação na época. A escolha das turmas se deu de maneira aleatória após o professor ser convidado a participar da atividade e as coletas foram realizadas no dia 8 de outubro de 2004 . No transcorrer da visita, o mediador realizou paradas estratégicas em frente aos recintos, priorizando os animais referentes aos objetos biológicos contidos na "mochila de curiosidades" utilizando seis objetos: bico de tucano, muda e guizo de cascavel, ovo e perna de ema, crânio de onça pintada e de tamanduá-bandeira. Tais materiais possuem curiosidades intrínsecas relacionadas à sua forma, constituição, função (alimentação, reprodução, defesa e camuflagem), sendo todos os objetos pertencentes a animais brasileiros. As transcrições dos diálogos da interação acima estão no Apêndice D. As interações foram registradas em fotos por Garcia (2006) e correspondem aos objetos biológicos trabalhados com o grupo escolar em frente ao recinto do respectivo animal. 


\subsection{SUJEITOS DA PESQUISA}

As entrevistas foram realizadas com a funcionária atual responsável pela gestão dos materiais educativos; a funcionária responsável pelo empréstimo dos kits para o público e a exfuncionária do Zôo de Sorocaba responsável pela concepção e produção dos materiais.

Além disso, serão analisados os diálogos de estudantes durante visita orientada usando a "mochila de curiosidade", já coletados por Garcia (2006).

\subsection{CARACTERIZAÇÃO DO LOCAL DE ESTUDO: O PARQUE ZOOLÓGICO MUNICIPAL QUINZINHO DE BARROS}

Para caracterizar o Parque Zoológico Municipal Quinzinho de Barros tomamos por base a pesquisa de Garcia (2006), documentos institucionais, observação pessoal e o site do zoológico de Sorocaba.

O primeiro zoológico de Sorocaba era uma pequena coleção de animais, formado em 1926 - o "Jardim dos Bichos". Depois de sua desativação, seus animais foram transferidos para o "Jardim da Margem" localizado as margens do rio Sorocaba, o segundo zoológico implantado na cidade em 1966. Esse local ganhou mais recintos para abrigar novos animais e, em 20 de outubro de 1968, foi inaugurado o Parque Zoológico Municipal Quinzinho de Barros, um grande parque público, onde mais animais foram incorporados à coleção do "Jardim da Margem”. Esses locais, em suas diferentes instalações, sempre despertaram grande interesse e reconhecimento do público, com o atrativo dos animais e pelos trabalhos desenvolvidos nas diferentes áreas (biologia, veterinária e educação). Tais atributos levaram o "Quinzinho" a ser eleito pela comunidade local por voto popular em 1993 como "símbolo da cidade" (GARCIA, 2006; ZOO SOROCABA, 2015).

O Zôo de Sorocaba passou, durante os anos de 2003 e 2004, por um grande projeto de revitalização, com a reestruturação e a construção de outros recintos, com uma nova forma de exposição, visando o bem-estar animal e maior interação com o público visitante. Houve também a implantação de um programa de comunicação visual educativa nas suas alamedas (ZOO SOROCABA, 2015).

Atualmente, o Zôo de Sorocaba (Figura 1) é um local onde a população da cidade e de toda a região encontra lazer e educação ambiental. É um zoológico considerado de grande porte, ocupando uma área de 128.339 metros quadrados, situada entre os bairros de Vila Hortência e 
Vila Haro. Aproximadamente 17.500 metros quadrados são ocupados pelo lago e $38.700 \mathrm{~m}$ por mata secundária, onde vivem livremente diversos animais, como bugios, bichos-preguiça, saguis, cutias, gambás, garças e pequenas serpentes. Possui cerca de 1.200 animais de 282 espécies diferentes da fauna nativa e exótica, recebendo 600.000 visitantes por ano e cerca de 90.000 alunos da rede pública e privada de 80 cidades diferentes, muitos deles utilizando os materiais educativos em diversas ocasiões. É formado ainda por um Centro de Educação Ambiental, Museu Histórico, Biblioteca, Auditório e Laboratórios (ZOO SOROCABA, 2015).

Figura 1: Parque Zoológico Municipal Quinzinho de Barros, Sorocaba, SP Fotos de Marcos Antonio Ferraz e Márcia Fernandes Lourenço

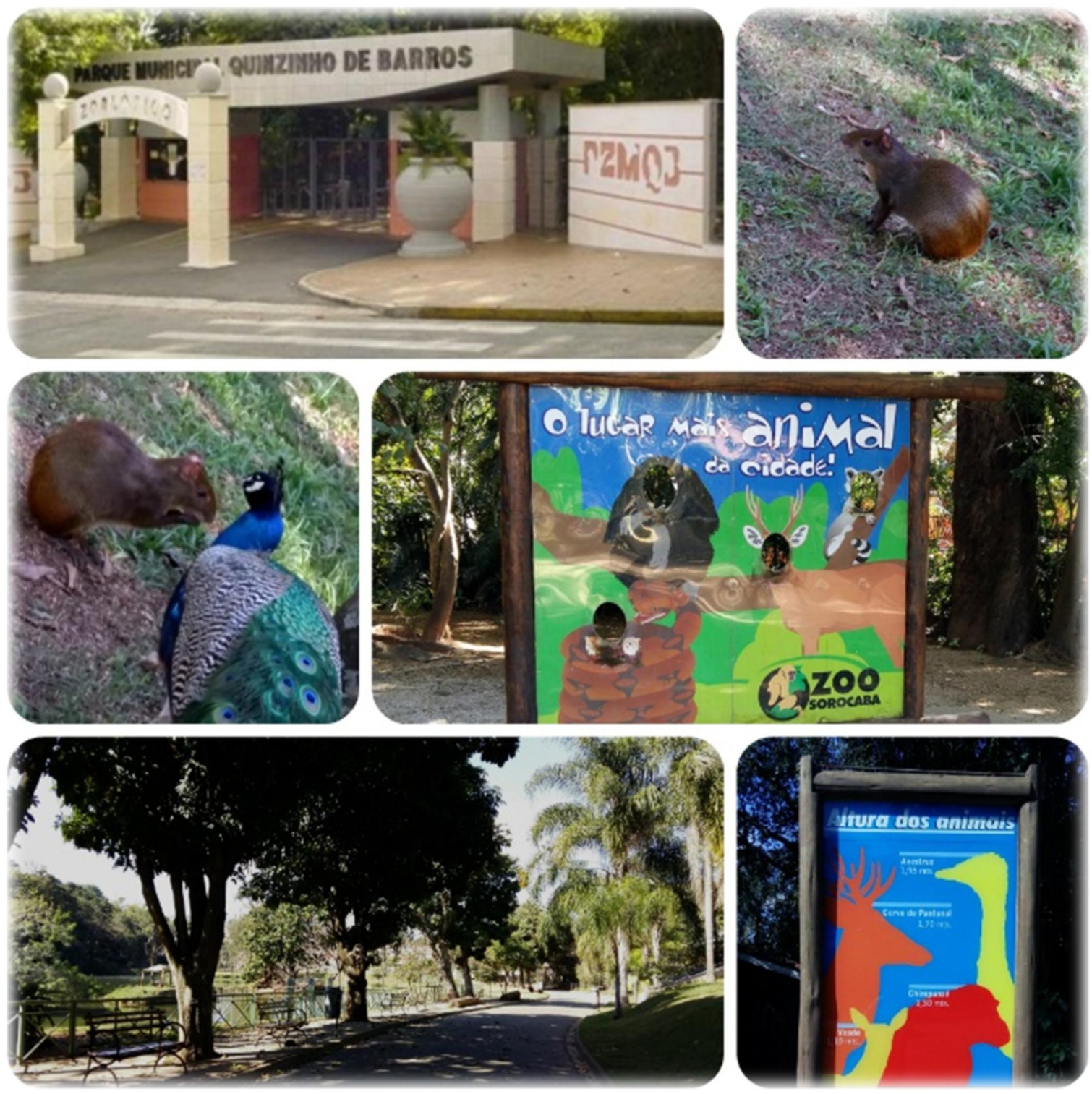




\subsection{ATIVIDADES EDUCATIVAS DO PARQUE ZOOLÓGICO MUNICIPAL QUINZINHO DE BARROS}

As atividades educativas do Zôo de Sorocaba são desenvolvidas pelo Centro de Educação Ambiental e tiveram início em 1974. Existe uma gama de atividades dirigidas a diferentes faixas etárias e públicos e estão divididas em três categorias: de impacto, de rotina e de continuidade (BELINASSI; MERGULHÃO, 2006; GARCIA; MARANDINO, 2006; GARCIA, 2006). As atividades "de impacto" compreendem os eventos realizados esporadicamente com o objetivo de chamar a atenção do público para determinado assunto, por exemplo, Expo-Verde, Dia Nacional do Lobo Guará, Mc Dia Feliz entre outros. Aquelas denominadas "de rotina" têm como objetivo fornecer maior vivência e conteúdo informativo, temos como exemplo as Visitas Orientadas, Empréstimo de Acervo Educativo, Zôo Vai à Escola, programas de formação etc. Por fim, as atividades "de continuidade" são aquelas que fornecem aos participantes um contato a longo prazo com as diferentes ações educativas que ocorrem na instituição, podendo apresentar ou não tempo determinado de duração, são elas Clube Conservadores da Natureza e Tranzôo (GARCIA; MERGULHÃO; ROLIM, 2007; ZOO SOROCABA, 2015; BELINASSI; MERGULHÃO, 2006; CHERUTTI; MATHIAS; GARCIA, 2011).

As atividades atualmente desenvolvidas são:

Zôo vai à Comunidade: A equipe do Zôo de Sorocaba visita espaços da comunidade (escolas e outras instituições) levando animais vivos, taxidermizados, jogos e pôsteres para uma exposição.

Tranzôo: Durante as férias ou finais de semana, desenvolvem-se atividades para grupos de crianças, adolescentes, famílias e idosos. As estratégias utilizadas são gincanas, exposições, excursões, madrugada ecológica, teatro, entre outras.

Clube Conservadores da Natureza: é formado por crianças e adolescentes que vão ao Zoológico uma vez por semana para aprender sobre assuntos relacionados à conservação do meio ambiente.

Exposições no Museu de Zoologia: Existem mais de 800 peças entre animais taxidermizados, esqueletos, ovos e animais conservados em álcool. Este material é utilizado para exposições, apresentações para pessoas com deficiência e empréstimos para a comunidade. 
Atendimento na Biblioteca: Os mais de 300 livros e revistas, ligadas à conservação, existentes na biblioteca estão à disposição do público geral e estudantes.

Visita Orientada: Esta atividade inclui um passeio pelo Zôo, dirigido por um mediador com opções entre caminhar pela mata, visitar a cozinha ou o museu. Durante a visita é utilizada a "mochila de curiosidade" que é carregada pelo mediador com objetos biológicos (patas, crânios, ovos etc.) referentes a partes dos animais vivos presentes na exposição. Quando os mediadores chegam a determinados recintos previamente escolhidos, retiram tais objetos da mochila e promovem discussões com o público a partir deles (GARCIA, 2006).

Empréstimo de Acervo Educativo: O acervo de kits ecológicos existente no Centro de Educação Ambiental do Zôo de Sorocaba é composto por 26 caixas com objetos biológicos conservados (plantas e animais), manual para o professor, folhetos, CDs, fitas de VHS, desenhos, modelos, animais de pelúcia, animais de plásticos, animais de papelão, moldes de pegadas, material indígena e livros, entre outros (ZOO SOROCABA, 2015).

\subsection{ANÁLISE DOS DADOS}

Os dados deste trabalho serão analisados seguindo a mesma lógica da coleta dos dados:

BLOCO 1

Concepção, produção e gestão dos materiais educativos.
BLOCO 2

Interação do público com o material educativo

\subsubsection{Concepção, produção e gestão dos materiais educativos}

A análise dos dados foi feita seguindo três passos consecutivos:

- Descrição dos materiais educativos - As descrições foram feitas a partir de nossas observações durante as visitas e registradas no Quadro 1 do Apêndice E.

- Aplicação dos indicadores e atributos de AC nos materiais educativos - Quando os indicadores e atributos apareceram nos itens analisados eles foram registrados na coluna "Indicadores e atributos de AC" da Quadro 1 do Apêndice E.

- $\quad$ Análise conjunta de nossas observações, entrevistas e documentos consultados - As entrevistas (Apêndice F) e os documentos foram submetidos a uma análise de conteúdo temática, seguindo os passos propostos Minayo (2008) que indica que esta análise consiste em 
descobrir os núcleos de sentido que compõem uma comunicação, cuja presença ou frequência signifiquem alguma coisa para o objeto de análise. Depois das leituras das entrevistas e documentos, selecionamos trechos que tratam de possíveis relações entre os materiais educativos e os indicadores de alfabetização científica e que nos permitiram inferir sobre o significado e o potencial dos materiais educativos para a alfabetização científica do público.

\subsubsection{Interação do público com o material educativo "mochila ade curiosidades"}

A análise da interação dos alunos com o material educativo "mochila de curiosidades" foi baseada na técnica das Sequências de Diálogos Representativos (SDR) proposta por Ash (2003), que define que qualquer conversa entre visitantes de museus pode ser analisada por segmentos que apresentem vínculos com o tema que está sendo trabalhado e, por isso, podem variar desde uma frase até um diálogo complexo, que estão inseridos em um diálogo maior, elaborado ao longo da interação.

A transcrição dos diálogos completos das crianças durante a visita utilizando o material "mochila de curiosidades" é apresentado no Apêndice D. Cada fala da criança, mediador ou professor é denominada turno por Ash (2003) e está identificada por números em sequência. Lembramos que a coleta desses dados foi feita por Garcia (2006).

Definimos como critério de seleção das SDRs aqueles diálogos entre o mediador-criança e criança-criança que se refira ao objeto apresentado por ele no momento da interação. As sequências de diálogos representativos (SDRs) estão destacados em amarelo e numerados conforme apresentado no Apêndice D.

Para analisar as interações construímos um quadro (Quadro 3 - Apêndice G) com os seguintes itens:

- Objeto biológico analisado durante a interação;

- Identificação das sequências de diálogo representativos (SDRs);

- Diálogo selecionado com a identificação dos turnos - trecho selecionado para análise;

- Indicador e atributo de AC

O Apêndice G (Quadro 3) apresenta as SDRs selecionadas e sua análise durante as interações com os objetos presentes no material. 
A análise das interações foi confrontada com entrevistas, documentos e publicações que trataram do material específico.

As visitas a museus se caracterizam como ricas fontes de objetos, pessoas, gestos e interações (MACMANUS, 1989), que podem apoiar seus visitantes na aprendizagem sobre o tema exposto e provocar a ligação entre sua bagagem cultural e as informações disponibilizadas. Entendemos que a interação com os objetos biológicos da "mochila de curiosidades" pode desencadear pensamentos e fazer surgir diversas ideias que podem ser exploradas pelo grupo durante a visita.

Temos convicção de que a técnica adotada nos auxilia a detectar se houve a interação com o objeto exposto e possibilita analisar o diálogo resultante de acordo com os indicadores e atributos descritos para esse fim.

\subsection{CRITÉRIOS DE VALIDAÇÃO E PROCEDIMENTOS DE CREDIBILIDADE DOS DADOS}

Segundo Alves-Mazzotti e Gewandsznajder (1999) é adequado que o pesquisador demonstre sua preocupação com o rigor com que os dados são coletados e analisados. Adotamos alguns procedimentos para maximizar a credibilidade e confiabilidade desta pesquisa.

- $\quad$ Procedemos à checagem das entrevistas pelas entrevistadas;

- Realizamos a triangulação utilizando vários procedimentos de coleta e análise dos dados;

- $\quad$ Aplicamos uma abordagem mista (qualitativo e quantitativo) na análise dos dados;

- Para reforçar a confiabilidade, uma parte dos dados desta pesquisa (aplicação dos indicadores e atributos nos materiais educativos) foi analisada também por duas pesquisadoras do GEENF (Grupo de Estudo e Pesquisa em Educação Não Formal e Divulgação da Ciência) que estão familiarizadas com o quadro teórico utilizado.

\subsection{FERRAMENTA DE ANÁLISE DOS DADOS: INDICADORES E ATRIBUTOS DE ALFABETIZAÇÃO CIENTÍFICA}

Como já foi apresentado nos capítulos anteriores, o processo de AC ocorre ao longo da vida das pessoas desde o período de escolarização e em outros ambientes de educação não formal quando o indivíduo tem contato com a ciência. Esse contato favorece a conquista de novos saberes, o aprofundamento de saberes adquiridos, a inter-relação desses saberes com as questões sociais aprimorando a Alfabetização Científica. 
Os jardins zoológicos juntamente com os demais museus de Ciências, são locais de aprendizagem que contribuem para o desenvolvimento de aspectos culturais, profissionais, ambientais e econômicos (CAZELLI, 1992; HENRIKSEN; FROYLAND, 2000; NORRIS; PHILLIPS, 2003; GARCIA, 2006; MERGULHÃO, 1997; AURICCHIO, 1999). Suas exposições, produtos e ações educativas lançam mão de diferentes estratégias para engajar o público em temas científicos, controversos e atuais.

Os indicadores e atributos de alfabetização científica foram desenvolvidos no sentido de buscar indícios da ocorrência deste processo em exposições, atividades educativas, materiais didáticos, documentos e o público nos espaços não formais de educação de acordo com os pressupostos das áreas de AC, educação em museus e comunicação pública da Ciência.

A ferramenta teórico-metodológica, inicialmente desenvolvida por Cerati (2014), baseia-se na construção de indicadores de AC (Científico, Interface Social, Institucional e Estético-AfetivoCognitivo) e seus atributos. Oliveira (2016) e Rocha (2016) ampliaram e aprofundaram a ferramenta, incluindo novos referenciais teóricos que visam a participação e o engajamento do público, que valorizam o diálogo e o protagonismo dele e, ainda, aqueles que destacam uma concepção de alfabetização científica associada a educação científica com abordagem CTS (Ciência-Tecnologia-Sociedade), incluindo a legitimidade e valorização de outros saberes e da construção conjunta do conhecimento. Para ampliar os diferentes contextos de análise que a ferramenta atual se propõe, também incorpora as discussões mais recentes do tema da apropriação social da ciência, e reúne ideias, preceitos e concepções sobre alfabetização científica que valorizam a participação da sociedade na tomada de decisão sobre assuntos de ciência em contextos variados como nas escolas, na mídia e nos museus e centros de ciência e que envolvem a abordagem de temáticas controversas, contemporâneas e polêmicas em torno da ciência, tecnologia e inovação.

\subsubsection{Indicadores e atributos para análise do processo de Alfabetização Científica}

\section{Indicador científico}

Neste indicador ressaltamos que uma ação de divulgação científica que pretende contribuir para a AC deve expressar a questão da natureza da ciência, fornecendo suporte para que o visitante construa seu conhecimento sobre assuntos científicos expostos. A criação deste indicador está embasada não só nos argumentos de diversos autores, como também nos documentos que direcionam AC como meta educacional (DECLARAÇÃO DE BUDAPESTE E PROJECT 
2061). Para Roberts (2007) e Fourez (1994), uma pessoa é considerada alfabetizada cientificamente quando tem conhecimento e entende os processos e produtos da ciência para participar da sociedade. Bybee e Deboer (1994) descrevem a AC como um processo contínuo no qual o indivíduo vai incorporando conhecimento e desenvolvendo um entendimento maior e mais sofisticado sobre ciência e tecnologia. Se a compreensão de conteúdos científícos é o ponto de partida para o processo de AC dos indivíduos (NORRIS, PHILIPS, 2003; ROBERTS, 2007; HURD, 1998), então trabalhar conteúdos científicos é, também, o ponto de partida para uma ação de divulgação científica que objetiva fomentar a AC de seus visitantes. (CERATI, 2014)

Assim, este indicador inclui a apresentação de aspectos inerentes ao conhecimento científico, como a apresentação de termos e conceitos (com explicitação ou não de seus signifícados) ligados a áreas específicas, teorias e ideias e seus significados legitimados pela ciência e contempla as pesquisas científicas, sejam elas aplicadas ou não, seus processos, resultados e aplicações, inovações, bem como a abordagem das pesquisas em andamento e/ou que estão sendo desenvolvidas na atualidade, considerando que ações de divulgação científica também podem abordar a ciência contemporânea e pesquisas que estão em desenvolvimento nas instituições de pesquisa, como defendem Pedretti (2002), Einsiedel e Einsiedel (2004), Delicado (2010) e Hine e Medvecky (2015).

Referenciais sobre Sociologia da Ciência também foram incluídos para embasar as discussões sobre os processos de produção de conhecimento científico e a dinâmica interna da ciência (LATOUR; WOOLGAR, 1979; KNORR-CETINA， 1981; LATOUR， 2000; CASTELFRANCHI, 2008; KUHN, 2005; SISMONDO, 2010).

Assim, nesse indicador temos o atributo relacionado ao processo de produção do conhecimento que abarca as discussões sobre as concepções de método científico, os métodos e procedimentos da ciência, como a formulação de hipóteses, realização de testes, registros, observação, criatividade, publicações científicas/acadêmicas, participação em eventos científicos, entre outros, a produção conjunta, a troca entre pares, de modo coletivo, interdisciplinar ou em redes de conhecimentos, a divulgação científica ou educação como parte do processo de produção do conhecimento e os atores sociais que participam do processo.

Tendo em vista o papel que o pesquisador assume no processo de produção do conhecimento, seus papéis no novo cenário da comunicação da ciência (FAGUNDES, 2013; 
CASTELFRANCHI, 2008; GRECO, 2007) ${ }^{1}$ e sua imagem e características assumidas na representação social (CGEE, 2015; CASTELFRANCHI; MASSARANI; RAMALHO, 2014; MESQUITA; SOARES, 2008; SIQUEIRA, 2008), incluímos nesse indicador atributos que destacam a referência aos pesquisadores envolvidos na pesquisa, estudo ou técnica científica apresentada; identificação das atribuições dos diferentes membros da equipe indicando a responsabilidade de cada um; a dimensão ética e responsabilidade social dos pesquisadores; a ciência como um produto da construção humana e características pessoais dos cientistas.

Por fim, trazemos a dinâmica interna da ciência e concepções de ciência que fundamentam as compreensões sobre seu processo de produção. Buscamos abarcar o caráter evolutivo e questionável da ciência, questões sobre o grau de incerteza, considerando os conflitos e controvérsias internas à sua produção, seu caráter histórico e filosófico e a não neutralidade do conhecimento científico (LATOUR; WOOLGAR， 1979; KNORR-CETINA， 1981; DELIZOICOV; AULER, 2011).

A seguir, uma síntese dos atributos do Indicador Científico:

1.a-Conhecimentos e conceitos científicos e suas definições:

- conceitos, leis, teorias e ideias científicas gerais legitimadas pela ciência sobre os temas abordados.

$1 . b$ - Pesquisas cientificas:

- resultados obtidos sobre o tema central das investigações;

- resultados atuais e/ou inovadores do ponto de vista global do avanço do conhecimento;

- pesquisas em andamento e/ou que estão sendo desenvolvidas na atualidade

${ }^{1}$ Para Fagundes (2013), Castelfranchi (2008) e Greco (2007), no novo cenário da comunicação científica discutido anteriormente, os cientistas também ganham novas atribuições e papeis. Mais que se destacar por meio de sua pesquisa, acumulando prestígio e reconhecimento no círculo acadêmico, o cientista deve ser um comunicador, divulgar os resultados de seu trabalho, se preocupar com a apropriação dos resultados pelo mercado, sendo um empreendedor e especialista na inter-relação entre conhecimento, técnica e mercado, e participar de campanhas que podem afetar seu campo de atuação. Esse novo cientista precisa desenvolver novas competências e passar a trabalhar, cada vez mais, fora de seu laboratório. 
1.c - Processo de produção de conhecimento científico:

- métodos e procedimentos da ciência: como a formulação de hipóteses, realização de testes, registros, observação, criatividade, publicações científicas/acadêmicas, participação em eventos científicos, entre outros;

- discussões sobre método científico;

- a produção conjunta, a troca entre pares, de modo coletivo, interdisciplinar ou em redes de conhecimentos;

- a divulgação científica ou educação como parte do processo de produção do conhecimento;

- os atores sociais que participam do processo.

1.d - Papel do pesquisador no processo de produção do conhecimento:

- referência aos pesquisadores envolvidos na pesquisa, estudo ou técnica científica apresentada;

- identificação das atribuições dos diferentes membros da equipe indicando a responsabilidade de cada um;

- a dimensão ética e responsabilidade social dos pesquisadores;

- a ciência como um produto da construção humana;

- características pessoais dos cientistas.

\section{1.e - Dinâmica interna da ciência:}

- o caráter evolutivo da ciência;

- o caráter questionável e o grau de incerteza, considerando os conflitos e controvérsias internas à sua produção;

- o caráter histórico e filosófico da ciência;

- a não neutralidade do conhecimento científico.

\section{Indicador Interface social}

Este indicador está presente quando a ação de divulgação científica tem potencial para propiciar o entendimento do significado social da ciência e explorar as inter-relações entre a ciência, tecnologia, inovação e a sociedade, expressando aspectos dos impactos da ciência na sociedade, a influência da economia e política na ciência, a influência e participação da sociedade na 
ciência, a identificação dos tipos de público, as ações e produtos de divulgação científica, educação formal e não formal. Ações que contemplam a interface social auxiliam o público a entender temas debatidos na atualidade e instrumentaliza os indivíduos para tomada de decisão na complexa sociedade contemporânea (CERATI, 2014).

Para estabelecer este indicador, buscamos suporte em autores que defendem os aspectos sociotécnicos-científicos para a promoção da AC, dentre eles Fourez (2003), Auler e Delizoicov (2001); Norris e Philips (2003); Bybee e Deboer (1994) e Sasseron e Carvalho (2008). Encontramos ainda embasamento para este indicador na visão de Hanzel e Trefil (1997), ao afirmar que a $\mathrm{AC}$ é o conhecimento necessário para o entendimento de temas públicos que possibilitam às pessoas refletirem, compreenderem, emitirem opinião e participarem do debate nacional acerca dos progressos científicos.

Entendemos que a ação de divulgação científica que apresenta atributos do indicador interface social está contemplando duas das três dimensões de AC propostas no clássico trabalho de Shen (1975): cívico - tornar o cidadão mais consciente sobre as questões relacionadas à/com a ciência, para tomada de decisão e atuação participativa no processo democrático dentro de uma sociedade cada vez mais tecnológica; prático - que aborda um tipo de conhecimento científico que auxilia o visitante a entender e relacioná-lo com questões do cotidiano. (CERATI, 2014). Assim, ser um cidadão alfabetizado cientificamente, no sentido cívico, é buscar informações, analisar, compreender, reavaliar, criticar, expressar opiniões e argumentar sobre questões de ciência e tecnologia relacionadas, especialmente, com a vida cotidiana, o futuro próximo e o imediato (FLEMING, 1989; LAYTON, 1988). Essas habilidades dialogam diretamente com os argumentos da educação CTS incorporados na presente discussão, defendidos por diversos autores como Aikenhead (1994), Luján-Lópes et al (1996), Santos e Mortmer (2000); Auler e Bazzo (2001); Auler (2002); Santos (2007) e da apropriação social da ciência (COLCIÊNCIAS, 2010, 2014; DAZA-CACIEDO, 2013).

Dessa forma, a noção de apropriação social da ciência envolve sentidos variados, abrangendo desde ideias que incorporam a noção de déficit do público até as que consideram noções pragmáticas de participação cidadã. Inclui, assim, as dinâmicas de tomada de decisões políticas, a gestão de conhecimentos científicos associados a problemáticas concretas, em processos denominados como engajamento público, ciência cidadã, popularização da ciência, divulgação do conhecimento, gestão do conhecimento, entre outros, envolvendo diversos atores, como o 
Estado, empresas privadas, sociedade civil, mediadores e a comunidade científica em geral (OLIVEIRA, 2016).

Deve-se considerar, também, que a ciência não é uma atividade política e eticamente neutra. Como aponta Fourez (1995), todo discurso científico é ideológico. Assim, a tomada de decisão relativa à $C \& T$ tem um forte componente ideológico que necessita ser levado em consideração. Aikenhead (1985) defende que para se tomar uma decisão é fundamental que se entenda o contexto político e econômico em que se produz C\&T. Assim sendo, outra importante vertente desse indicador é a incorporação de temas ligados às discussões sobre Natureza da Ciência e da política e economia da ciência no ensino de ciências, a partir das discussões de Erduran e Mugaloglu (2013), e da comunicação pública da ciência, em especial, aqueles que preconizam modelos participativos e que visam a participação e o engajamento do público (ALLUM; BAUER; MILLER, 2007; GREGORY; MILLER, 1998; LEWENSTEIN, 2003; LEWENSTEIN; BROSSARD, 2006).

Desse modo, incorporamos nesse indicador os atributos: "impactos da ciência na sociedade" que abrange os aspectos positivos ou negativos, riscos e benefícios do desenvolvimento da C\&T, as controvérsias externas às ciência, explicitamente sobre sua relação com a sociedade, as questões éticas envolvidas na relação da ciência com sociedade; a conexão com o cotidiano e a resolução de problemas sociais e a influência da ciência nas questões sociais, históricas, políticas, econômicas, culturais e ambientais; "influência da economia e política na ciência" que trabalha as discussões sobre os fatores políticos, econômicos e comerciais que influenciam as pesquisas científicas e o desenvolvimento da C\&T, aspectos relacionados ao financiamento da ciência, aspectos relacionados a propriedade intelectual, patentes e transferência de tecnologia; e "a influência e participação da sociedade na ciência" que lida com questões como a origem e o desenvolvimento da pesquisa a partir de demandas da sociedade, o conhecimento e a opinião da sociedade sobre a ciência, seus processos, produtos e resultados, a efetiva participação da sociedade nas decisões sobre ciência e a utilização dos resultados da ciência pela sociedade para tomada de decisões e empoderamento, a legitimidade de outras formas de conhecimento e a valorização dos saberes locais na pesquisa e os impactos da ação da sociedade e do ser humano na pesquisa científica (principalmente quando se trata de meio ambiente).

Adicionamos ao Indicador Interface Social, ainda, um aspecto relacionado à possibilidade de identificação de distintos tipos de público, isto é: se a ação de divulgação científica é destinada a públicos diferentes, como à comunidade científica ou público especializado, ao público 
escolar ou à comunidades ou grupos específicos com perfis caracterizados, e se essa ação é configurada a partir da demanda e características específicas desse público, como a linguagem usada e o modo como o conhecimento divulgado é abordado.

Por fim, nesse indicador está um atributo relacionado à oferta, distribuição e disponibilização de outras ações e produtos de divulgação científica, educação formal e não formal como forma de extensão e continuação da popularização da ciência e informação científica de qualidade para o público. Nesse atributo podem ser incluídos meios que oferecem informações sobre onde o público pode se atualizar e se informar sobre questões científica e ações ou produtos veiculados pela mídia e redes sociais, como reportagens em TV, rádio, youtube, facebook, revistas, livros, filmes, peças teatrais, exposições etc; publicações científicas; ações de ensino de ciências no contexto escolar e ações de formação de públicos específicos como professores, educadores, entre outros. Esse atributo ganha relevância nos argumentos de Fourez (1994), ao reconhecer que uma das habilidades necessárias para que um cidadão seja considerado alfabetizado cientificamente é reconhecer não só a origem da ciência, mas também as fontes válidas de informações científicas e tecnológicas e recorra a elas quando diante de situações de tomada de decisões. Nesta proposição, Fourez destaca três objetivos: o primeiro refere-se ao conhecimento de fontes de informação; o segundo, ao saber fazer para selecionar as informações necessárias a cada situação; e o terceiro destaca o papel de se criar o hábito de realizar verdadeiras investigações como forma de colocar em prática os dois objetivos anteriores.

A seguir, uma síntese dos atributos do Indicador Interface social:

\section{2.a - Impactos da ciência na sociedade:}

- aspectos positivos ou negativos, riscos e benefícios do desenvolvimento da C\&T;

- controvérsias externas à ciência, explicitamente sobre sua relação com a sociedade;

- questões éticas envolvidas na relação da ciência com sociedade;

- a conexão com o cotidiano e a resolução de problemas sociais;

- influência da ciência nas questões sociais, históricas, políticas, econômicas, culturais e ambientais. 
2.b - Influência da economia e política na ciência:

- fatores políticos, econômicos e comerciais que influenciam as pesquisas científicas e o desenvolvimento da C\&T;

- aspectos relacionados ao financiamento da ciência;

- aspectos relacionados a propriedade intelectual, patentes e transferência de tecnologia.

2.c - Influência e Participação da sociedade na ciência:

- a origem e o desenvolvimento da pesquisa a partir de demandas da sociedade;

- o conhecimento e a opinião da sociedade sobre a ciência, seus processos, produtos e resultados;

- a efetiva participação da sociedade nas decisões sobre ciência e a utilização dos resultados da ciência pela sociedade para tomada de decisões e empoderamento;

- a legitimidade de outras formas de conhecimento e a valorização dos saberes locais na pesquisa;

- impactos da ação da sociedade e do ser humano na pesquisa científica (principalmente quando se trata de meio ambiente).

\section{2.d - Identificação dos tipos de público:}

- à comunidade científica ou público especializado;

- ao público escolar;

- à comunidades ou grupos específicos com perfis caracterizados.

2.e - Ações e produtos de divulgação científica, educação formal e não formal:

- ações ou produtos veiculados pela mídia e redes sociais, como reportagens em TV, rádio, youtube, facebook, revistas;

- produções diversas como livros, filmes, peças teatrais, exposições, etc;

- publicações científicas;

- ações de ensino de ciências no contexto escolar;

- ações de formação de públicos específicos como professores, educadores, entre outros.

\section{Indicador Institucional}


O indicador institucional expressa a dimensão das instituições envolvidas com a produção e o fomento da ciência e sua função social (MARANDINO, 2001), permitindo identificar quais são instituições envolvidas, bem como aspectos políticos, científicos e culturais relacionados (KRASILCHIK, 2009; CERATI, 2014). Quando presente nas ações de divulgação científica, permite identificar, por exemplo, a missão institucional relacionada ao ensino, pesquisa e extensão, à formação de recursos humanos e às ações de divulgação e educação científicas.

Marandino (2001) e Achiam e Marandino (2013), por exemplo, consideram que a política institucional tem o poder de decisão sobre a abordagem do discurso expositivo, para além de componentes científicos. Esse poder permeia fatores políticos, de gestão, dos órgãos financiadores e da política de governo ao qual está subordinada. Assim, o indicador institucional na exposição, quando existente, permite que os visitantes reconheçam a função social da instituição, ampliem seu repertório relativo à cultura científica e compreendam os aspectos sociais, políticos e culturais que envolvem a produção da ciência ${ }^{2}$.

Conforme Cerati (2014, p. 81)

“A importância deste indicador está em facilitar a aproximação do cidadão com a ciência produzida na academia, da qual, muitas vezes, os museus de ciências são integrantes, além de permitir a percepção que a produção social da ciência envolve sua dimensão institucional”.

Nessa perspectiva, no Indicador Institucional, temos um atributo relacionado à identificação das instituições envolvidas na produção, fomento e divulgação da ciência, como instituições executoras e/ou colaboradoras dos projetos, órgãos governamentais e/ou privados envolvidos,

\footnotetext{
${ }^{2}$ Nas pesquisas de Percepção Pública da Ciência no Brasil revelam que o conhecimento dos brasileiros sobre instituições do país que se dedicam a fazer pesquisa científica é muito baixo. Uma parcela muito pequena da população consegue lembrar alguma instituição de pesquisa. Em 2006, 16\% dos brasileiros se lembraram de alguma instituição que faça pesquisa no país e, em 2010, 17,9\%. Em 2015, o percentual caiu para apenas 12,4\%. Questões sobre financiamento também são encontradas nas três pesquisas. Em todas elas, os brasileiros foram perguntados sobre quem investe mais dinheiro para a pesquisa científica e tecnológica do país (tendo como opções de respostas: iniciativa pública, iniciativa privada e organizações internacionais). Em 2015, outra questão sobre financiamento sofreu uma modificação, e perguntou: Sabendo que os recursos de qualquer governo são limitados, e que gastar mais com alguma coisa significa ter que gastar menos com outras, você acredita que o Governo deveria aumentar, manter ou diminuir os investimentos em investigação científica e tecnológica nos próximos anos? Assim, fica claro que conhecer instituições que fazem pesquisa, como é feito o financiamento das pesquisas e como isso influencia nos rumos e no desenvolvimento da C\&T no país são questões relevantes para um cidadão alfabetizado cientificamente.
} 
órgãos governamentais de fomento como CNPq, CAPES, MCTI, FAPs, entre outros, órgãos privados de fomento e outras instituições e organizações. Outro atributo está relacionado à identificação da missão institucional, isto é, se a ação de divulgação apresenta aspectos da missão institucional relacionados ao ensino, pesquisa e extensão, à educação e divulgação científica e inovação e/ou à formação de recursos humanos. Finalmente, há, também, um atributo relativo à presença de elementos políticos, culturais e sociais ligados à instituição que envolvem: o processo de produção e difusão de conhecimento, a dimensão histórica da instituição e seu papel para o desenvolvimento científico, a importância das pesquisas e/ou das coleções mantidas pelas instituições.

A seguir, uma síntese dos atributos do Indicador Institucional:

3.a - Identificação das instituições envolvidas na produção, fomento e divulgação da ciência:

- instituições executoras e/ou colaboradoras dos projetos;

- órgãos governamentais e/ou privados envolvidos;

- os órgãos governamentais de fomento como CNPq, CAPES, MCTI, FAPs;

- os órgãos privados de fomento;

- outras instituições e organizações.

\section{3.b - Identificação da missão institucional:}

- aspectos da missão institucional relacionados ao ensino, pesquisa e extensão;

- aspectos da missão institucional relacionados à educação e divulgação científica e inovação;

- aspectos da missão institucional relacionados à formação de recursos humanos.

3.c - Presença de elementos políticos, culturais e sociais ligados à instituição que envolvem:

- o processo de produção e difusão de conhecimento;

- a dimensão histórica da instituição e seu papel para o desenvolvimento científico;

- a importância das pesquisas e/ou das coleções mantidas pelas instituições.

\section{Indicador Estético/Afetivo/Cognitivo}

O indicador estético-afetivo-cognitivo está presente quando a ação de divulgação científica tem potencial para despertar dimensões relacionadas à afetividade, interação, percepção, motivação 
e aprendizagem. Quando presente nas ações de divulgação científica, é possível reconhecer a intenção e o potencial para sensibilizar o público e envolvê-lo de diversas formas possibilitando a aprendizagem por meio de diferentes formas de interação. Quando aplicado para análise do público, se revela a partir das manifestações de sentimento e por meio de expressões e ações dos sujeitos que revelem operações epistêmicas e habilidades investigativas. Esse indicador considera, também, o formato da comunicação e se a ação de divulgação científica possibilita o estabelecimento de uma relação dialógica e interativa do público. Ademais, identifica também a acessibilidade das ações, isto é, se existe a possibilidade de diversas formas de acesso ao conhecimento, por diferentes tipos de público, em especial, aquele com algum tipo de deficiência.

A seguir, uma síntese dos atributos do Indicador Estético-Afetivo - Cognitivo:

\section{4.a - Estético e Afetivo}

Este atributo pode ser identificado quando uma ação ou produto apresenta, em suas estratégias, potencial para estimular manifestações de sentimentos como apreço, prazer, repulsa, indignação ou outras sensações, tanto em relação a ciência quanto a formato como ela está sendo apresentada. Além disso, possibilita momentos de contemplação e de apreciação estética e artística, oportunizando a expressão de experiências pessoais. Do ponto de vista da análise de público, pressupõe a manifestação dos sentimentos indicados na relação dos sujeitos com os objetos de conhecimento nas visitas ou ações educativas. Nesse atributo, também há a identificação se a ação promove o incentivo à contemplação e à apreciação estética e artística ou se têm potencial para ser desafiadora e surpreendente, podendo despertar a motivação para interação (TEIXEIRA, 2014).

\section{4.b- Cognitivo}

Este atributo pode ser identificado quando uma ação ou produto apresenta, em suas estratégias a possibilidade de promover habilidades relacionadas aos processos de investigação científica e operações epistêmicas como observação, nomeação, afirmação, comparação, caracterização, suposição, explicação, questionamento, emissão de opinião, conclusão e generalização, a partir da interação com o objeto. Do ponto de vista da análise de público, pressupõe à expressão de evidências de operações epistêmicas e de habilidades investigativas na relação dos sujeitos com os objetos de conhecimento nas visitas ou ações educativas.

\section{4.c - Interação física e sensorial}


Esse atributo considera os diversos níveis de interatividade física e sensorial com o produto ou objeto (WAGENSBERG, 2001) e se a ação de divulgação científica possibilita e estimula uma relação entre os diversos atores envolvidos, identificando, também se há valorização dos conhecimentos prévios do público. Esse atributo foi baseado nas discussões recentes de comunicação pública da ciência, em especial, aquelas que preconizam modelos participativos e que visam a participação e o engajamento do público (ALLUM et al, 2007; GREGORY; MILLER, 1998; LEWENSTEIN, 2003; LEWENSTEIN; BROSSARD, 2006; BUCCHI, 2015; 2004; BUCCHI; NERESINI, 2008), que valorizam o diálogo, o protagonismo do público e a discussão da ciência contemporânea nos museus de ciências (CHITTENDEN; FARMELO; LEWENSTEIN, 2004; DELICADO， 2009; MACDONALD; SILVERSTONE， 1992; PEDRETTI, 2002; PEDRETTI; IANNINI; NAZIR, 2014).

A partir dos indicadores propostos, é possível analisar o conjunto de materiais educativos existentes nas instituições museológicas na perspectiva da alfabetização científica. A aplicação desses indicadores na análise nos materiais educativos suscita reflexões sobre o seu papel para o desenvolvimento dos processos educativos nos museus que trazem importantes contribuições para a produção e a análise do uso desses materiais. Podem assim, fornecer subsídios a educadores e a outros profissionais interessados na produção de materiais educativos nestes espaços de educação. 
5. ANÁLISE DOS RESULTADOS 
Os resultados desta pesquisa são apresentados em dois blocos e analisados à luz da ferramenta teórico-metodológica apresentada no Capítulo 4.
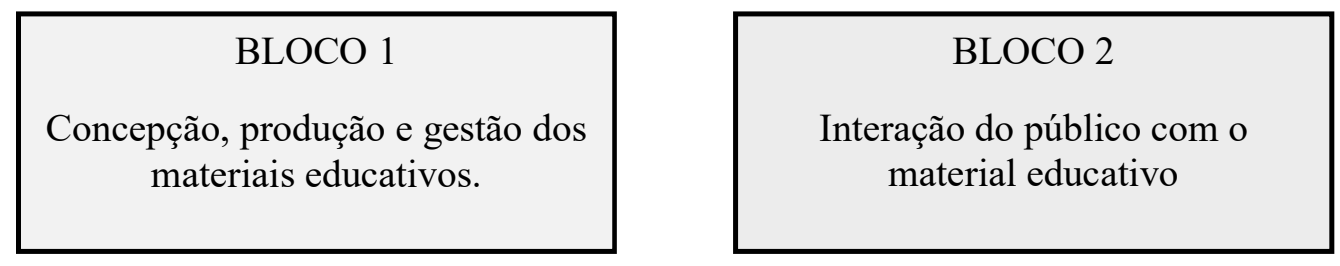

Lembramos que os dados do primeiro bloco serão apresentados e analisados com base na coleta feita por meio das entrevistas, da pesquisa documental e das observações realizadas por nós junto aos materiais do Zôo de Sorocaba. Os dados do segundo bloco serão apresentados e analisados com base na coleta de dados feita por Garcia (2006) em sua dissertação de mestrado, relativo à interação do público escolar com o material "mochila de curiosidades" em uma visita.

\subsection{CONCEPÇÃO, PRODUÇÃO E GESTÃO DOS MATERIAIS EDUCATIVOS.}

Dividimos a apresentação dos resultados deste item em dois segmentos. Neste primeiro segmento, apresentaremos a análise com base nas observações gerais, entrevistas e nos documentos tendo por foco as intenções dos idealizadores ao produzirem e utilizarem os materiais educativos. Assim, buscamos contextualizar brevemente essas atividades a partir de nossas observações e dos documentos consultados e descrever com que finalidades e como os materiais são utilizados nas ações educativas do Zôo de Sorocaba. Os trechos foram selecionados a partir da leitura profunda e exaustiva dos dados, tendo como norte os indicadores e atributos de AC.

No segundo segmento, apresentaremos a análise qualitativa e quantitativa dos materiais educativos propriamente ditos, aplicando as categorias de análise - indicadores e atributos de AC a cada um deles e expressando os resultados de forma quantitativa a partir de nossas observações, mas também considerando as informações oriundas das entrevistas e documentos.

\subsubsection{As intenções e os usos dos materiais educativos no Zôo de Sorocaba: contextualizando o objeto de estudo}

O Zôo de Sorocaba tem como objetivo principal proporcionar ao seu público um conhecimento maior sobre os animais, suas relações e seus ambientes, visando desenvolver habilidades e compromissos que se traduzam em decisões e ações responsáveis em relação à manutenção dos recursos naturais e da qualidade de vida (GARCIA, 2006). Outros objetivos são: oferecer 
recreação saudável e contato com a natureza, programas de educação ambiental, colaboração com pesquisas gerando conhecimento sobre comportamento, reprodução e fisiologia, e atuando junto ao esforço conservacionista nacional e mundial através de planos de manejo, tanto em cativeiro como na natureza (ZOO SOROCABA, 2015).

Os Relatórios Anuais do Centro de Educação Ambiental examinados e as entrevistas realizadas corroboram os objetivos encontrados nas publicações e no site do zoológico, por exemplo, o Relatório Anual de 1993 afirma que um dos objetivos do Zôo de Sorocaba é “....aumentar a consciência ecológica na relação ser humano-natureza objetivando torná-los conscientes de suas responsabilidades com relação ao ambiente" (RELATÓRIO ANUAL,1993). A entrevistada 3 mencionou várias vezes em suas falas tais objetivos afirmando que "Os conteúdos tratados na mediação são questões ambientais, interação entre os animais, conservação, interação homem-ambiente, conceitos de ecologia”. Além disso, esta mesma entrevistada afirma que havia a intenção de ensinar sobre os animais, seu ambiente e possibilitar a discussão de questões de políticas públicas e o papel de cada indivíduo na conservação da natureza.

Ainda dentre os objetivos expressos nas falas da entrevistada 3 e nos Relatórios Anuais de 1993 e 1997, identificamos a preocupação com o aprendizado de conceitos sobre a vida, relações e história natural dos animais ali presentes, o trabalho com conceitos de Biologia durante as visitas, que, na visão dos responsáveis, pode potencializar as discussões sobre conservação e o papel do ser humano neste contexto. A relação do ser humano com os animais e o ambiente são considerados, nos objetivos da instituição, importantes para promover a discussão de assuntos polêmicos relacionados ao tema.

Conhecer tais objetivos esclarece o caminho tomado pelo setor na decisão de produzir materiais educativos e das discussões e avaliações realizadas a respeito dos "kits ecológicos" e da "mochila de curiosidades" que encontramos nos Relatórios Anuais analisados e nas mudanças de percurso pelas quais a utilização dos materiais passou ao longo do tempo. Assim no que se refere especificamente aos materiais, os objetivos são trabalhar a educação ambiental, relação dos animais com o ambiente, características morfológicas e adaptativas dos animais, conservação e conhecimento de espécies ameaçadas de extinção, impacto do consumo excessivo pelo ser humano e da poluição são destacados nos Relatórios Anuais de 1997, 2001, 2003 e 2009. 
A seguir iremos explicitar com mais detalhes como os materiais educativos são usados nas atividades as quais estão vinculados, buscando assim caracterizar melhor as intenções e concepções dos mesmos.

\subsubsection{A mochila de curiosidades e a visita orientada}

A “mochila de curiosidades" (Figuras 2a e 2b) é constituída por diversos tipos de objetos, que podem ser partes de animais originais preservados, réplicas e modelos, variando dependendo da época e da temática abordada: bico de tucano, pata e ovo de ema, crânio de onça, tamanduá e arara azul, muda e guizo de cascavel, vidro de palmito, cano de transporte de aves, fezes secas de animais, modelos de pegadas, pele de serpente, microchip, tripa de mico, pilha, saco plástico, girino, xaxim, fibra de coco, pata de falconiforme, bauxitas.

Atualmente existem 4 exemplares da mochila, todos com os mesmos objetos, mas somente 2 estão disponíveis para utilização. As outras 2 estão com material incompleto aguardando disponibilidade de acervo para serem utilizadas. Estes dados foram observados, durante visita inicial exploratória ao Centro de Educação Ambiental do Zôo de Sorocaba realizada em 2014.

No momento da coleta dos dados deste trabalho, os objetos presentes na mochila eram: vidro de palmito, microchip, crânio de onça, pele de tamanduá, anilha, pote com fezes de anta, crânio original de arara-azul, pata taxidermizada de ave, cano de tráfico de aves, pele de serpente, molde de pata de felino (Figuras 2a e 2b). Importante destacar que em 2006, quando foi feita a coleta de dados por Viviane Rachid, que serão utilizados neste trabalho na análise junto ao público, os objetos na mochila eram muda e guizo de cascavel, bico de tucano, crânio de onça, pata e ovo de ema, indicando uma dinâmica na composição dos objetos da mochila ao longo do tempo. 
Figuras 2a e 2b: Objetos presentes na mochila de curiosidades no momento atual Fotos de Márcia Fernandes Lourenço

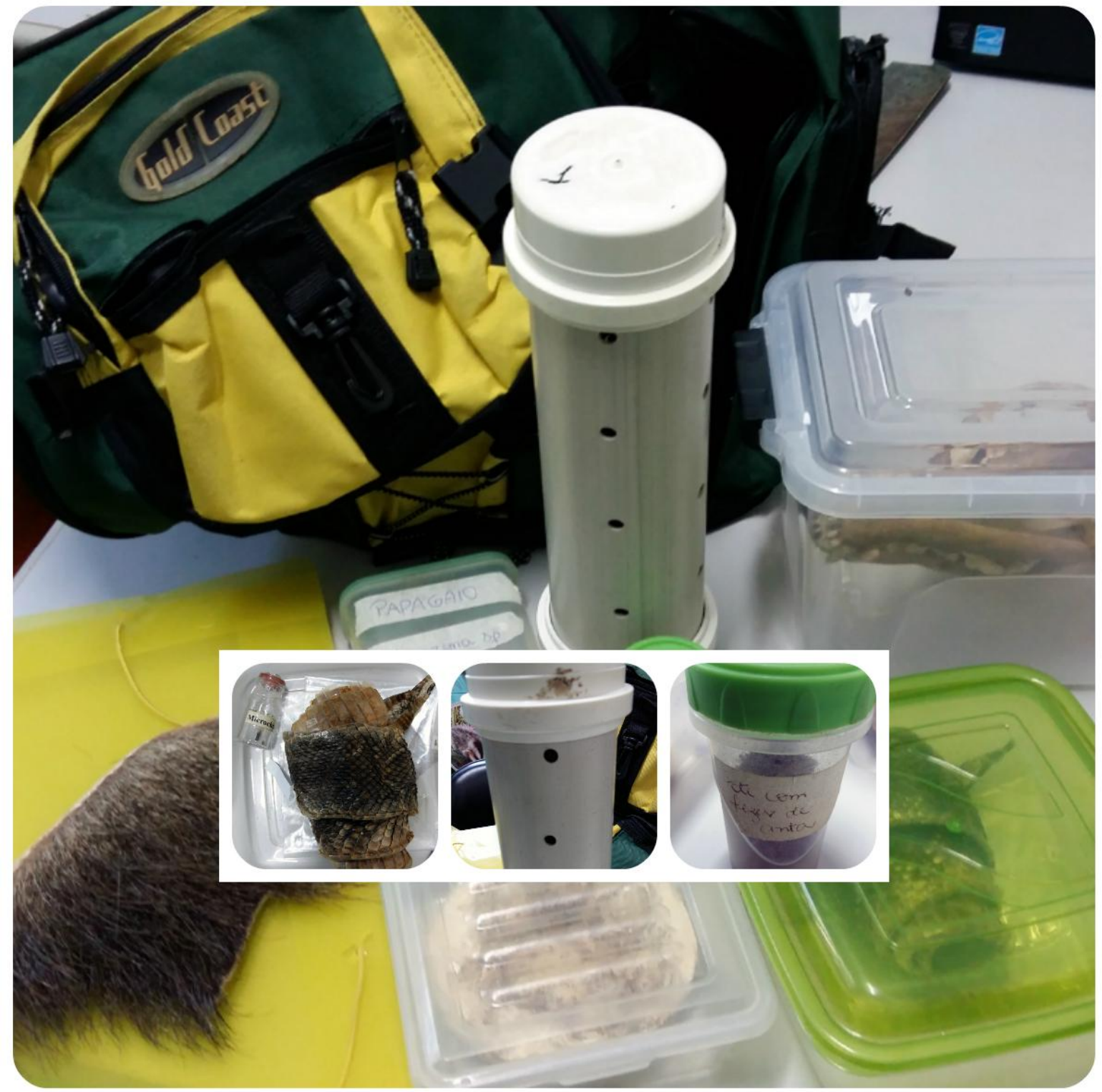



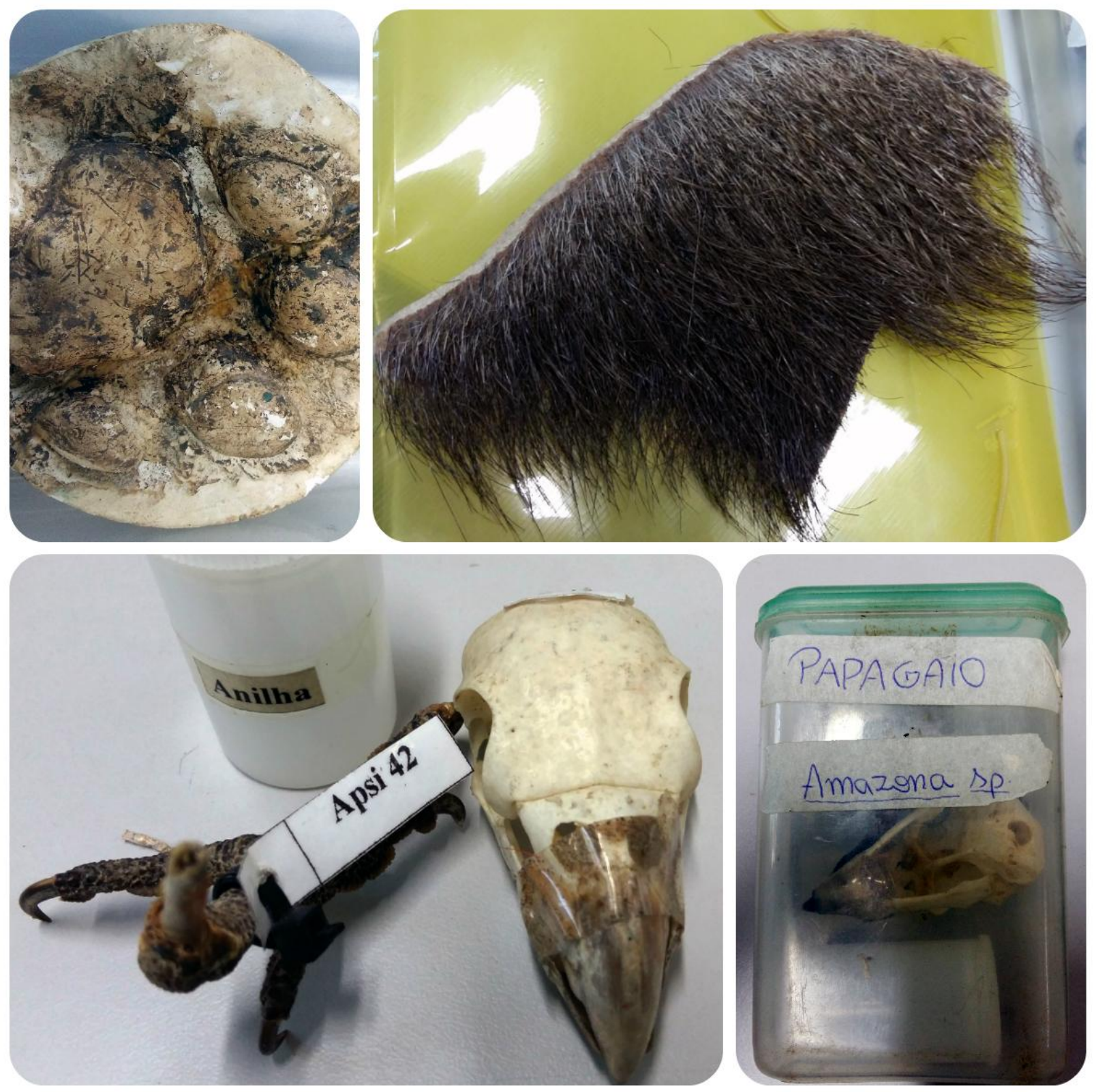

$2 b$

A criação e utilização da mochila está vinculada a atividade de visita orientada desenvolvida pelo Zôo de Sorocaba desde 1983. Esta ação consiste em momentos de interação entre o público e o mediador durante o percurso pelas alamedas do espaço expositivo. Ela é realizada somente com o público escolar que visita o Zoológico e, de acordo com Garcia (2006), alguns pontos são levados em conta para a escolha do percurso, para a definição do trajeto e do discurso da visita: a adequação do discurso e do roteiro à faixa etária do público e preferência do público pelos animais maiores e de comportamento ativo. As explicações dos mediadores incluem 
dados biológicos dos animais, algumas de suas características e curiosidades, destacando os principais fatores que contribuem para sua conservação em vida livre, numa linguagem simples e adaptada ao público.

A atividade de visita orientada está dividida em três etapas: $1^{\circ}$ : Bate Papo sobre os objetivos da atividade e apresentação da instituição; $2^{\circ}$ : Visita pelos setores do Zôo para conhecer os recintos dos diferentes animais existentes, nativos e exóticos com o uso da mochila; $3^{\circ}$ : Visita aos bastidores do Zôo (GARCIA; MARANDINO, 2006).

Durante a visita os mediadores utilizam-se da "mochila de curiosidades". Ela entra em cena em frente a cada recinto selecionado para o roteiro, onde o mediador faz uma parada estratégica e retira os objetos referentes ao animal da exposição, promovendo diferentes interações. Todos podem ser manuseados pelos visitantes.

A visita orientada tem como objetivos estimular as discussões sobre biologia, comportamento e conservação dos animais. Segundo Garcia (2006), o uso dos objetos preservados nesta atividade é importante por instigar a curiosidade, demonstrar os conceitos por meio de objetos concretos, sensibilizar, ilustrar as informações e estimular a reflexão em relação aos valores e aspectos políticos relacionados a conservação. Verifica-se, então que os elementos envolvidos no planejamento e desenvolvimento da atividade e no próprio uso dos objetos presentes na mochila contemplam aspectos cognitivos, afetivos e sociais, abordando também as relações entre ciência e sociedade por meio do tema da conservação.

Os objetivos da visita e do uso dos objetos foi corroborado nas entrevistadas de nossa pesquisa, já que nelas afirmou-se que este material foi criado para tornar as visitas mais motivadores aos estudantes. Para a entrevistada 3 "A produção das mochilas surgiu do fato de eu ser educadora e ter a preocupação de tornar as visitas mediadas mais concretas e interativas" e sua função é a de estimular a curiosidade e a atenção das crianças. Já para a entrevistada 2, "a mochila facilita, ajuda, chama mais atenção, gera mais interesse, mais do que uma pessoa falando sem nada (para mostrar)" e pode "...tornar as visitas mediadas mais concretas, mais interativas...deixar mais interessante (a monitoria) ... "além de despertar a curiosidade das crianças".

O Relatório Anual de 2003 também nos aponta alguns dos objetivos da produção de materiais educativos para manipulação como sendo "Despertar interesse, motivar" e também para enriquecer a metodologia utilizada durante a mediação (RELATÓRIO ANUAL, 2003). 
O Relatório Anual de 2009, vol. II apresenta uma pesquisa realizada entre os professores após o uso da "mochila de curiosidades". Esta foi realizada no recinto do Zôo com 16 professores que participaram da visita com a utilização da mochila. Foram feitas perguntas aos professores sobre os materiais da mochila, dentre elas estão: "Qual a parte da visita que mais chamou atenção?" e "Quanto ao conteúdo abordado?". Dos professores pesquisados, 6 deles apontaram que a parte que chamou mais atenção na visita "foi o contato com os objetos biológicos preservados" presentes na mochila. Com relação à segunda questão foram identificadas as seguintes afirmações: "Fundamental para a imaginação dos alunos"; “Despertou o interesse dos alunos" (RELATÓRIO ANUAL, 2009).

Nas observações acima coletadas percebemos a preocupação em apresentar materiais que estimulem os visitantes a se envolverem na visita relacionando os objetos da mochila com os animais vistos no recinto. Percebemos também que os documentos e as entrevistas destacam o entusiasmo e a motivação do público quando entra em contato com os materiais.

Consideramos que um elemento chave para a participação numa atividade é a motivação, a partir dela a visita torna-se mais dinâmica e a reflexão sobre as questões abordadas se consolidam. Essa ação possibilita o contato com novas experiências, estimuladas pela curiosidade e pela interação com o objeto biológico, o que foi sempre valorizado no material do Zôo (GARCIA; MERGULHÃO, 2004).

Segundo Garcia e Marandino (2006), em estudo sobre a visita orientada no Zôo de Sorocaba o uso deste material enriquece a visita, motiva a participação dos visitantes, torna o conhecimento mais acessível ao público e a visita mais dinâmica. Algumas das falas das entrevistadas evidenciam essa questão, como a da entrevistada 3 que afirma que os recursos da mochila podem ser um disparador e facilitador do discurso da mediação ao mostrar um objeto que se refira ao conceito que está sendo abordado e que a experiência direta de manipulação e contato físico com o material proporciona conhecimentos científicos e cria discussões de conceitos biológicos. A entrevistada 2 complementa afirmando que a interação com esses materiais também pode ter um efeito positivo de atenção pois traz os conceitos mais próximos da realidade do público.

Outros fatores importantes na utilização da "mochila de curiosidades" destacados na publicação de Garcia e Marandino (2006) são aguçar a curiosidade do visitante possibilitando o levantamento de hipóteses, criar um ambiente de investigação e possibilitar a comparação entre os animais vivos e o objeto preservado da mochila. Pudemos confirmar esta questão também 
na fala da entrevistada 3 que afirma que as crianças ficam curiosas, abertas e dispostas a ouvir quando em contato com os objetos e tornam-se estimuladas a perguntar e expressar suas ideias e fazer conexões dos aspectos de seu cotidiano com as questões trabalhadas. O Relatório Anual de 2009, vol. II afirma também que um dos objetivos da criação da mochila era aguçar a curiosidade do visitante possibilitando o levantamento de hipóteses e a construção de conhecimentos de conceitos biológicos (RELATÓRIO ANUAL, 2009).

Os dados acima apontam para a importância desses materiais dada pelo Zôo, revelada também nas pesquisas feitas com base nesses objetos, para que o visitante tenha oportunidade de elaborar hipóteses com relação a temas como caça ilegal e conservação ambiental. Os visitantes também podem ter contato com os processos de preparação e coleta do material, proporcionando interação e diálogo entre os participantes e contemplação mais aprofundada dos objetos.

O trabalho de 2011 de Cherutti, Mathias e Garcia investigou a aplicação da sacola ecológica (precursora da mochila de curiosidades) como recurso educativo de ensino-aprendizagem durante a visita mediada. Este material foi utilizado pelo Zôo de Sorocaba com o intuito de preparar os alunos para a visita. Além de um guia do professor, roteiro e DVD, materiais biológicos representativos de alguns animais que são vistos durante a visita estavam presentes neste material. As autoras investigaram 2 turmas de alunos visitantes do Zôo de Sorocaba, uma delas utilizou o material antes da visita e outra não. O trabalho concluiu que a utilização da sacola ecológica é um importante recurso didático na assimilação dos conceitos apresentados durante a visita. Este aspecto também está presente na "mochila de curiosidades" produzida depois com base nos resultados do trabalho com a sacola ecológica.

As entrevistas, relatórios e publicações apontam que o material educativo "mochila de curiosidades" também pode representar um importante aliado na construção de conceitos científicos e seus significados. As entrevistadas 2 e 3 comentam que os materiais trazem conteúdos biológicos como por exemplo, interação animal-planta, conservação, interação homem-ambiente, conceitos de ecologia, alimentação, cadeia alimentar, classificação animal, biomas e ecossistemas, biodiversidade, características dos animais, adaptações dos animais, dependência dos anfíbios da água entre outros, e têm como objetivo primeiro, ensinar conceitos de biologia para desenvolver a compreensão dos problemas ambientais. No relatório de 2009, vol. II, também a aparece a importância dos materiais para a construção de conceitos científicos 
pois o contato com esses objetos biológico “... dá oportunidade aos alunos de sentirem textura, temperatura e outros detalhes dos animais" (RELATÓRIO ANUAL, 2009).

$\mathrm{Na}$ pesquisa de Garcia e Marandino (2007), as autoras realizaram um levantamento para verificar se e como os objetos biológicos eram usados pelos zoológicos brasileiros e enviaram questionários para 80 instituições, obtendo 25 respostas no total. Uma das conclusões foi de que esse recurso auxilia no processo de ensino e aprendizagem dos programas educativos dos zoológicos, o que aponta a relevância dada por estas instituições no uso desses materiais.

Outro aspecto importante apontado pelas entrevistas foi que a questão afetiva e sensorial também está presente durante a interação com os objetos da "mochila de curiosidades". Garcia (2006) nos conta em sua dissertação de mestrado, ter observado que o fato de um visitante chegar perto de uma onça pintada taxidermizada, ver o seu tamanho real, sentir sua textura e observar bem de perto seus enormes caninos, constituía uma experiência única para o público frequentador do Zôo. Ficou evidente para autora a atração do público por esses objetos, seja pela oportunidade de chegar muito próximo do animal ou pela curiosidade de conhecer suas características in loco.

As entrevistadas 2 e 3 manifestaram estes aspectos em suas falas, como vemos a seguir "...elas querem ver de perto, podem pegar..." e "Alguns tocam, chegam perto, mas outro nem querem chegar perto". As entrevistadas contaram também que alguns visitantes sentem repulsa ao se aproximarem dos objetos originais conservados, especialmente partes de animais destacadas do corpo (cabeça, pata, pele, etc.), como afirma a entrevistada 3: “Acho que para quem não está acostumado deve dar uma certa estranheza, pegando cadáver".

Mergulhão (2002), investigou os animais com os quais as pessoas têm menos afinidade (cobra, sapo, aranha, rato, barata, entre outros) e verificou que uma das possíveis origens das sensações e dos sentimentos negativos para com esses animais está relacionado com as informações adquiridas, ou ausência delas. Esses dados reforçaram a importância dos zoológicos como promotores de informações científicas e interação com esses animais cujo resultado pode ser não só o desenvolvimento de sentimentos positivos, mas também a minimização dos sentimentos negativos. Além disso, verificamos que pode contribuir para a $\mathrm{AC}$ já que cria uma empatia que pode atrair o visitante para a informação científica sobre o animal e envolvê-lo com o tema tratado. 
As entrevistas nos indicam que as controvérsias e questões polêmicas não foram uma prioridade durante a concepção dos materiais educativos. As falas das entrevistadas indicam uma breve discussão sobre tráfico e preservação dos animais como prioridades, como evidenciado a seguir

“... (o cano de transporte) cria uma discussão sobre caça ilegal e tráfico de animais" e "Quando você mostra o crânio da onça, você mostra a ameaça e a pessoa vai pensar neles e tentar pensar como ela "tá" influenciando na ameaça, como poderia ser diferente". No entanto, quando o mediador manipula o vidro de palmito, algumas discussões sobre temas como higiene e doenças advindas da preparação ilegal do palmito, vêm à tona, como exemplificado nas afirmações das entrevistadas 2 e 3 "Acho que quando os monitores falam sobre o palmito, o modo de fazer sem higiene, que eles podem pegar doenças, gera uma reflexão nas pessoas, como é na casa delas..." a entrevistada 3 afirmou que "O vidro de palmito desperta discussão polêmica e que as crianças questionam e trazem questões de sua experiência em casa sobre compra de palmito legal, ilegal e discussões com os pais sobre o assunto. Os documentos analisados não citam em nenhum momento alguma intenção em tratar de questões polêmicas que eventualmente pudessem ser trazidas à tona no trabalho com a "mochila de curiosidades" durante a visita.

\subsubsection{Os kits ecológicos}

No segundo semestre de 1994 foram criados pelo Centro de Educação Ambiental do Zôo de Sorocaba, materiais educativos destinados a empréstimo e uso no próprio Zôo denominados Kits Ecológicos. Esses materiais são utilizados em várias ações educativas no próprio Zoológico e emprestados para professores usarem nas suas aulas, alunos realizarem trabalhos escolares, atividades da polícia ambiental e trabalho de conclusão de curso.

Os Relatórios Anuais de 1994 e 1997 e a publicação de Bellinassi e Mergulhão (2006) justificam a produção deste material como: multiplicar as ações de Educação Ambiental na sociedade, produzir recursos instrucionais como subsídio às aulas de Ciências, Biologia e Educação Ambiental, oferecer material que leve os alunos à compreensão do modo de vida, hábitos, informações morfológicas e adaptações dos animais ao meio ambiente e incentivar a reflexão sobre a importância da preservação do ambiente para a sobrevivência das espécies e melhoria na qualidade de vida.

As entrevistadas 1, 2, e 3 nos contam que os professores se utilizam desses materiais para dar aulas sobre animais, sendo que eles são ricos em informações sobre biologia, características dos animais, modo de vida, reprodução, interação homem-ambiente e apresentam “... uma interação entre os conceitos de biologia e o de conservação". A entrevistada 3 afirma que além de auxiliar 
o professor na sala de aula, eles também podem “...difundir as questões científicas para a comunidade de Sorocaba".

Salientamos uma das afirmações do Relatório Anual de 2001 destacando a importância do material para o enriquecimento das aulas:

"Tendo em mãos uma simples caixa com uma vértebra de serpente e um hemipênis de cascavel ou até mesmo um couro da maior serpente brasileira acompanhados de slides, livros e um guia, o professor poderá descobrir e ensinar coisas maravilhosas sobre o mundo animal e como este interage com o ambiente" (RELATÓRIO ANUAL, 2001)

Nas publicações, nos relatórios e nas falas das entrevistadas, algumas delas citadas acima, percebemos que a preocupação em fornecer informações sobre os animais e relações com o ambiente é bastante presente. Os materiais também foram pensados para complementação e enriquecimento das aulas de Ciências e Biologia. As entrevistas também nos indicam que o público alvo para o qual foram concebidos é prioritariamente professores e alunos. No entanto, como a fala da entrevistada 3 nos mostra no parágrafo anterior, as vezes os educadores do Zôo utilizam os materiais para atividades no próprio zoológico com a comunidade em geral.

Os kits ecológicos estão inseridos nas "atividades de rotina" do Zôo de Sorocaba (GARCIA, 2006) e foram aperfeiçoados de acordo com avaliações feitas pelos professores usuários (RELATÓRIO ANUAL, 1995). A produção inicial foi de 4 kits (adaptações dos animais para defesa, alimentação, reprodução e locomoção), mas ao longo do tempo forem sendo produzidos novos kits por sugestão dos professores usuários e da própria equipe, dependendo da disponibilidade de acervo biológico, material e financiamento. Nem todos os kits e materiais observados por nós estão indicados no site do zoológico.

Conforme verificamos nas visitas exploratórias iniciais, estes materiais estão disponíveis para professores, alunos e comunidade em geral. Para realizar o empréstimo, as pessoas preenchem um formulário de solicitação, retiram e devolvem os materiais no local e podem permanecer com eles por 7 dias. A divulgação é realizada no site da instituição e para as escolas da cidade por meio de folhetos informativos (BELLINASSI; MERGULHÃO, 2006; ZOO SOROCABA, 2015). 
Atualmente existem 26 kits e nossa descrição é comparada com aquela apresentada no site do zoológico. Agrupamos os kits por temas - Ecossistemas, Animais, Estruturas adaptativas nos animais, Saúde, Ecologia, Etnias indígenas.

Ecossistemas: Ambiente Marinho - Praia Arenosa e Costão Rochoso; Água doce/rios; Cerrado; Ecossistemas brasileiros.

Animais: Peixes do Rio Sorocaba; Artrópodes, Aves I e II; Anfíbios; Dinossauros; Mamíferos I e II; Répteis I e II; Animais Peçonhentos.

Estruturas adaptativas nos animais: Defesa; Alimentação; Locomoção; Reprodução.

Saúde: Parasitose Humana; Lixo I e II.

Ecologia: Interação animal-planta.

Etnias indígenas: Índio I e II.

Cada conjunto de kit é guardado em caixas plásticas grandes contendo outros recipientes, como sacos plásticos, pequenas caixas, pastas, recipientes de vidro e papelão onde encontram-se os objetos menores que formam o conjunto. Os materiais são identificados com uma etiqueta na tampa externa da caixa, na lateral e na parte interna da tampa, na maioria das vezes, contém uma lista com o conteúdo da caixa (nem sempre coincidente com o conteúdo encontrado por nós).

Abaixo apresento a descrição a partir de nossas observações e a comparação com o que é apresentado no site do zoológico.

\section{Ecossistemas}

1. Praia arenosa (Figura 3): No interior da caixa existe uma pasta contendo os livros - Preserve os Oceanos, John Baines, Ed. Scipione; Como a Natureza Funciona, Guia Prático de Ciências Ed. Globo; Vida Marinha, John Croft, Ed. Melhoramento e um manual do professor elaborado pela equipe de educação ambiental do Zôo de Sorocaba. Existe também um folheto sobre montagem e conservação de aquário marinho (sem identificação de autoria). Os animais em via úmida (álcool 70\%) estão abrigados em dois frascos de vidro e os em via seca e a areia estão em 11 potes plásticos. Nem todos os itens descritos no site do zoológico estão presentes. Os itens que compõem este kit, segundo nossas observações são: 
- Animais em via seca: estrela-do-mar, marisco, rala-coco, sapinhagá, ofiuróide, borboleta (concha), Strombus (concha), Anadara (concha), Olivancilaria (concha), Sanguinolaria (concha).

- Animais em via úmida: poliqueta, camarão.

- Outros: manual do professor, livros e areia do mar.

Figura 3: Objetos constituintes do kit Praia Arenosa Fotos de Márcia Fernandes Lourenço
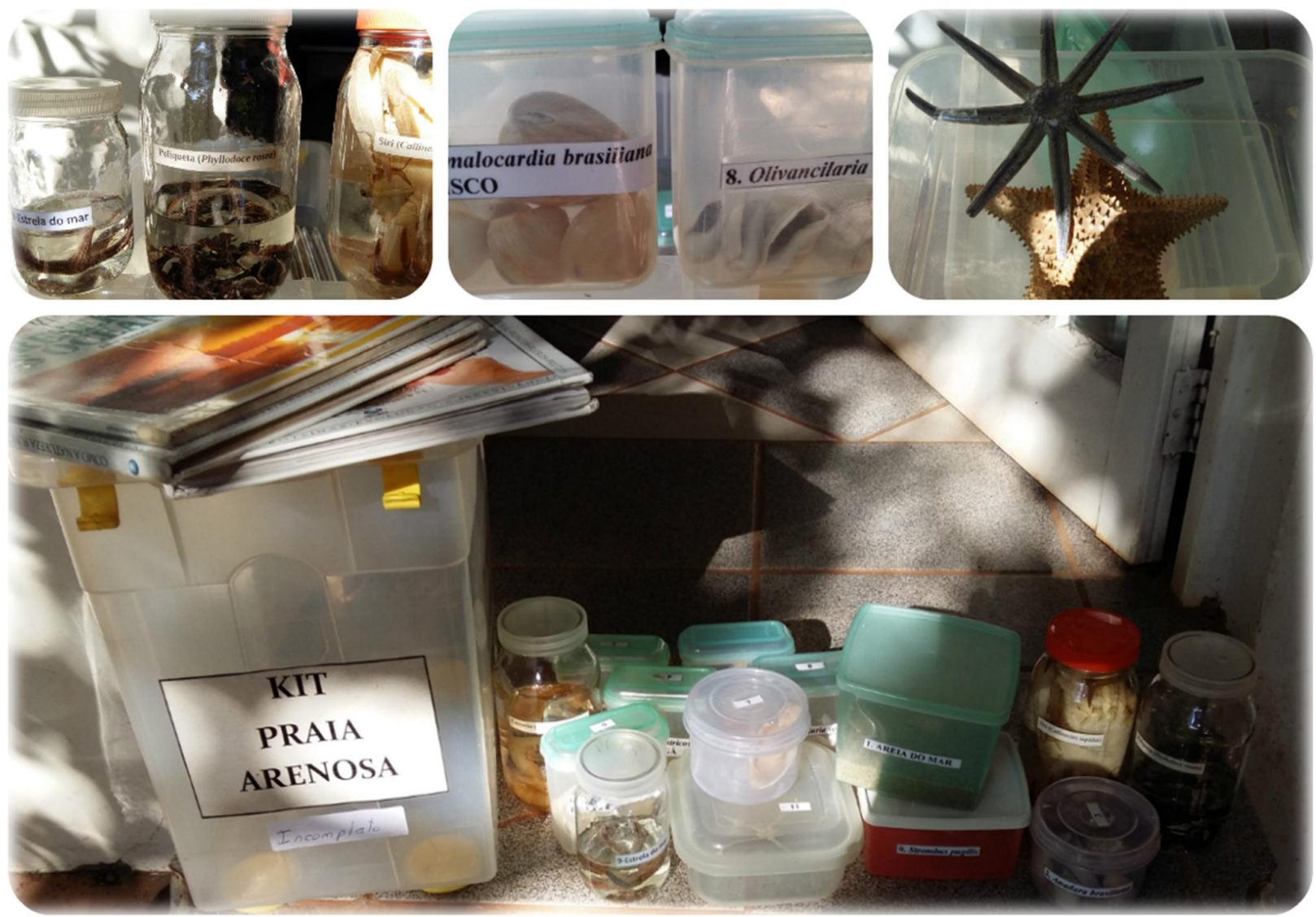

2. Costão Rochoso (Figura 4): No interior da caixa existe uma pasta com os livros - Aventura visual/litoral, Ed. Globo; Coleção vida marinha/ as algas, ouriço do mar e a esponja do mar, Ed. Globo; Criaturas marinhas, George Gordon, DCL e um manual do professor (de autoria da equipe de educação ambiental do Zôo de Sorocaba) que tratam do conteúdo relacionado à costão rochoso e aos animais que vivem neste ambiente. Os animais estão abrigados em 9 caixas 
plásticas menores e 9 frascos de vidro. Nem todos os materiais citados no site do zoológico estão presentes na caixa. Os itens que compõem este kit, segundo nossas observações são:

- Animais e plantas em via úmida: caranguejo-vermelho, lula, lírio-do-mar, anêmona, alga parda (Sargassum), alga verde.

- Animais e plantas em via seca: barata de praia, alga parda (laminária), rosquinha, coral chifre-de-veado, coral cérebro, esponja, ouriço-do-mar, ermitão, estrela-do-mar, mexilhão, Calistoma (molusco), Thais (molusco), cracas.

- Outros: manual para o professor, livros.

Figura 4: Objetos constituintes do kit Costão Rochoso Fotos de Márcia Fernandes Lourenço
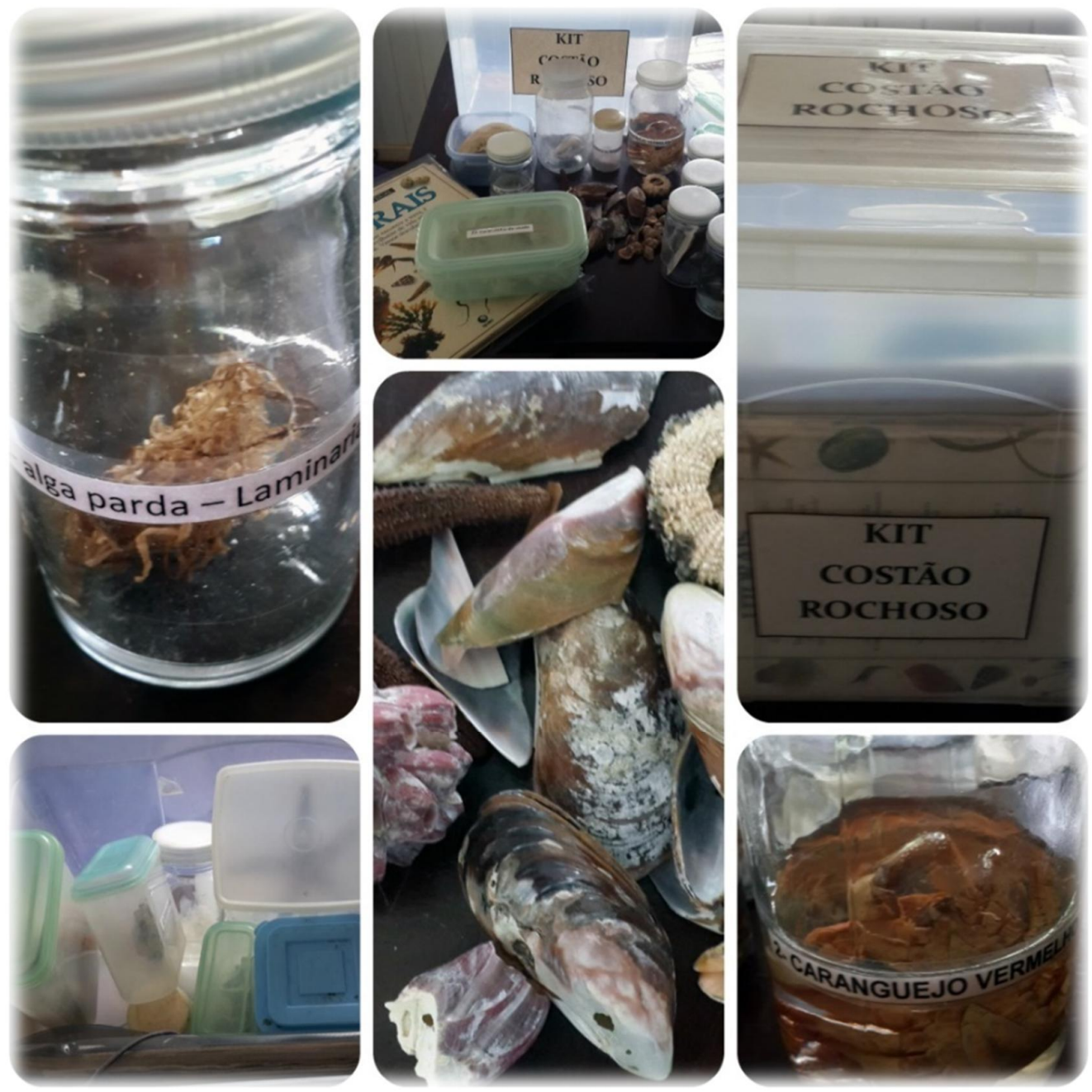
3. Água doce/rios (Figura 5): No interior da caixa grande existem 4 caixas menores de plástico, numeradas e identificadas contendo animais originais conservados. O conjunto possui também 4 livros (Belo Riozinho, Elisabete Trigo, Ed. Celibra; Vamos Cuidar dos nossos rios? Luis Fernando Schettino e Fátima Gonçalves, Ministério do Meio Ambiente; Água e Ar - A natureza em nossa vida Vol. II, Gonçalves Ribeiro, Ed. Sugestões literárias) que tratam de temas relacionados à água, com fotos de peixes de água-doce e informações de como montar um aquário de água-doce. Não há um manual para o professor neste kit. Nem todos os materiais citados no site do zoológico estão presentes na caixa. Os itens que compõem este kit, segundo nossas observações, são:

- Animais em via seca: piranha, molusco de água doce

- Partes de animais: dente, escama e mandíbula de pirarucu, bicos de garça e socó, crânio de capivara.

- Outros: livros, fotos de peixes e folhas de sulfite soltas com informações sobre aquário de água-doce (sem autoria).

Figura 5: Objetos constituintes do kit Água doce/rios Fotos de Márcia Fernandes Lourenço

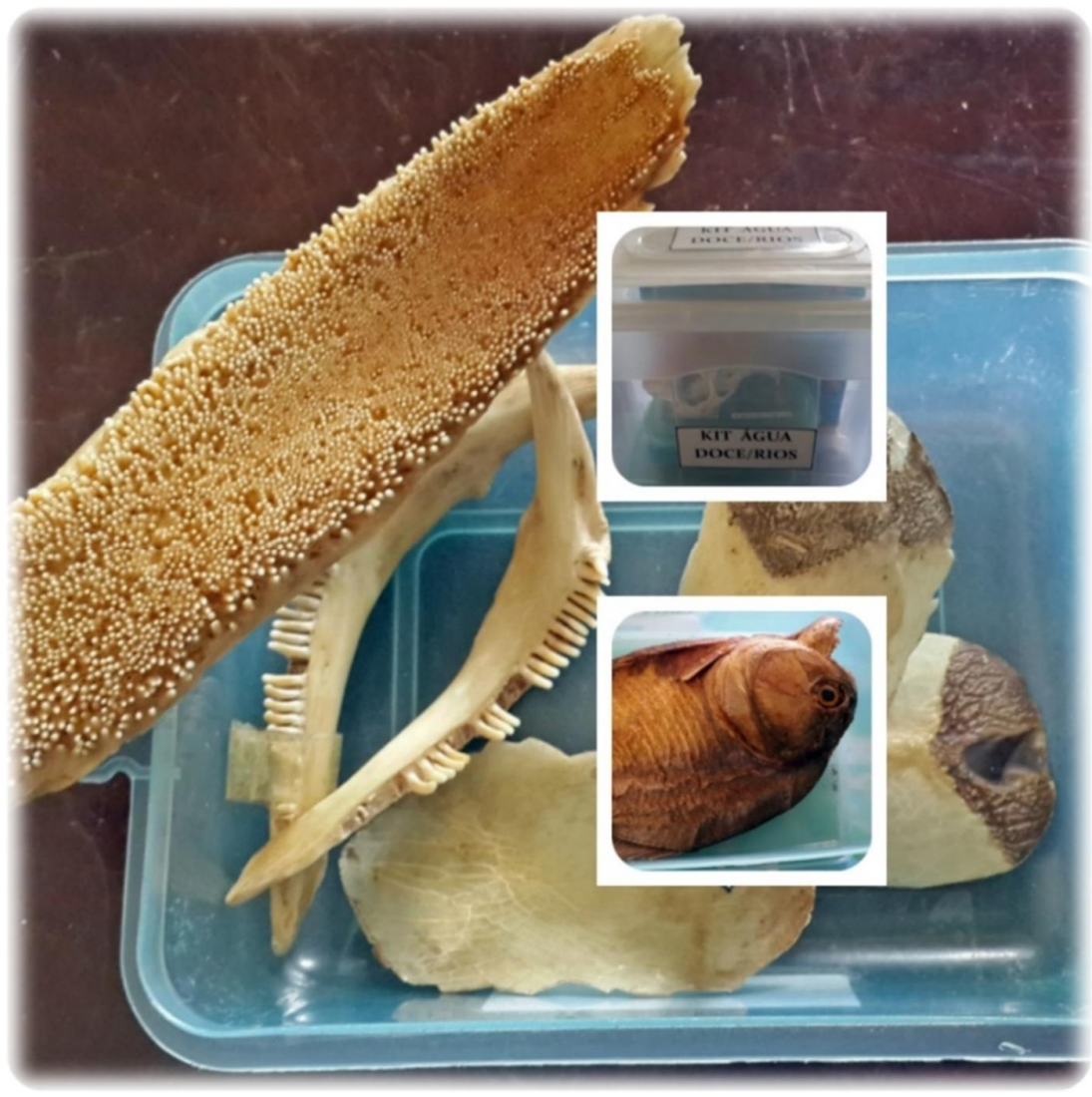


4. Cerrado (Figura 6): No interior da caixa maior existem caixas plásticas com diversos materiais. Todo o conjunto é acompanhado por duas pastas com o livro O Lobo Kiko e o Cerrado Brasileiro, Willian Gaertner, CDMM Editora, manual do professor, material para experimento sobre solo, pranchas com plantas do cerrado (sem autoria), molde para máscara de lobo guará e jogo de autoria da equipe do Zôo. Alguns materiais descritos no site do zoológico não estavam presentes no momento de nossas observações. Abaixo, os materiais do kit a partir de nossas observações.

- Partes de animais em via seca: pata de ema, crânios de tamanduá e veado, bico de tucano, cabeça e patas de coruja suindara, espinho de ouriço-cacheiro, fezes de veado, ecdise de cigarra, cupinzeiro.

- Partes de plantas secas: galho de árvore, sucupira, cacau-selvagem, folhas e flores.

- Experimento: amostra de solo de jardim, solo arenoso e solo do cerrado; 3 funis; 3 copos plásticos, 1 pinça e 1 lupa manual.

- Outros: manual para o professor, livros sobre lobo-guará e cerrado, prancha com plantas do cerrado, molde de máscara de lobo-guará.

- Jogo: Bingo do cerrado. 
Figura 6: Objetos constituintes do kit Cerrado Fotos de Márcia Fernandes Lourenço
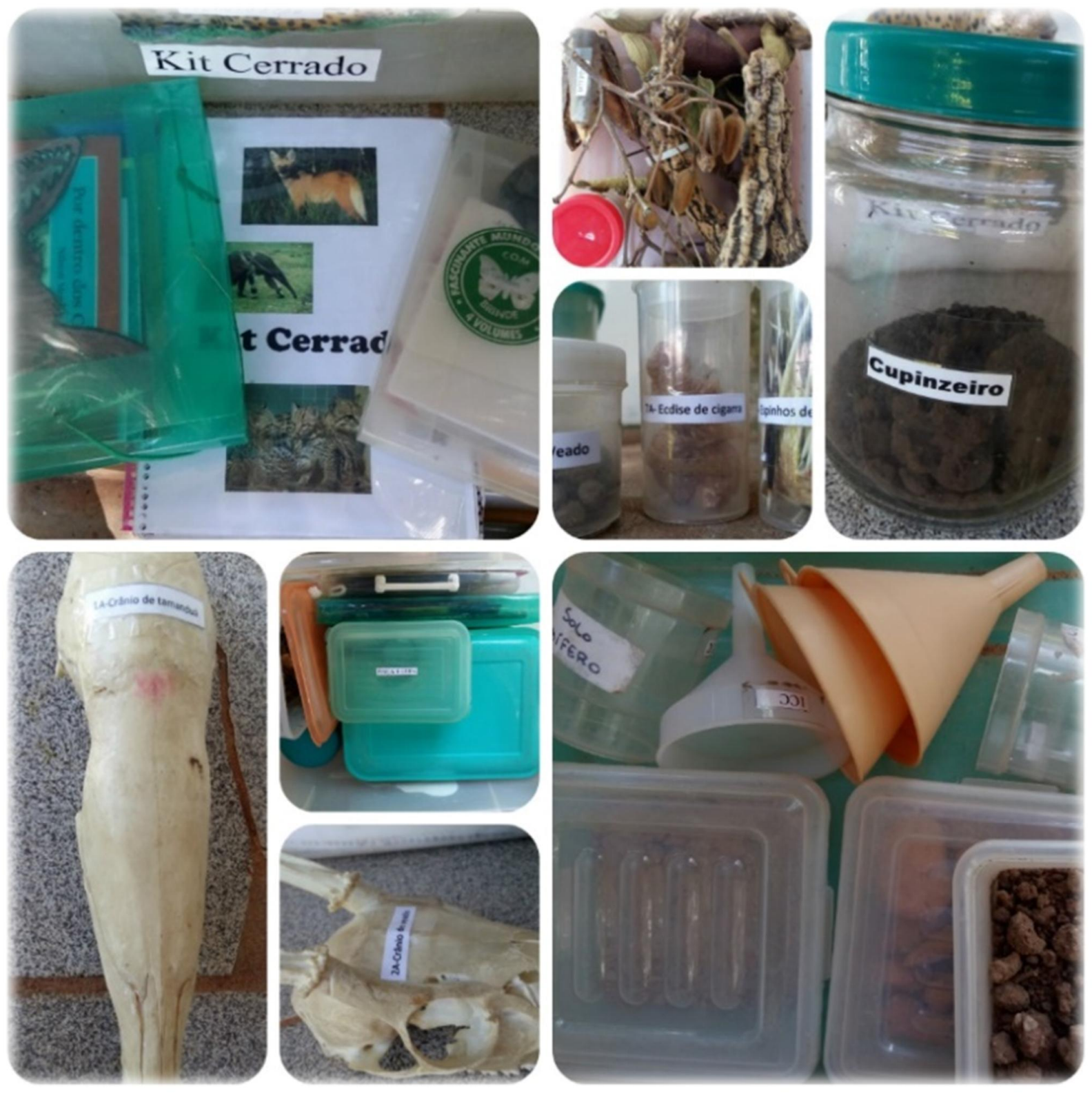

5. Ecossistemas brasileiros (Figura 7): Dentro da caixa grande existem 3 frascos de vidro contendo plantas em álcool 70\%, 2 pastas com exsicatas de plantas e material bibliográfico (Plantas. Série Atlas Visuais. Ed. Ática; Farmácia da Terra. Ferreira, M., CRF; Plantio de Arvores - Como fazer? Prefeitura de Sorocaba) e um manual para o professor. Segundo nossas observações, o kit é composto por:

- Plantas em via úmida: cacto, planta aquática e galho de bromélia. 
- Exsicatas: 17 pranchas com exsicatas de plantas de diversas espécies.

- Outros: manual para o professor, prancha com morfologia de uma flor, livro, folheto da prefeitura de Sorocaba e apostila sobre plantas medicinais.

Figura 7: Objetos constituintes do kit Ecossistemas brasileiros Fotos de Márcia Fernandes Lourenço

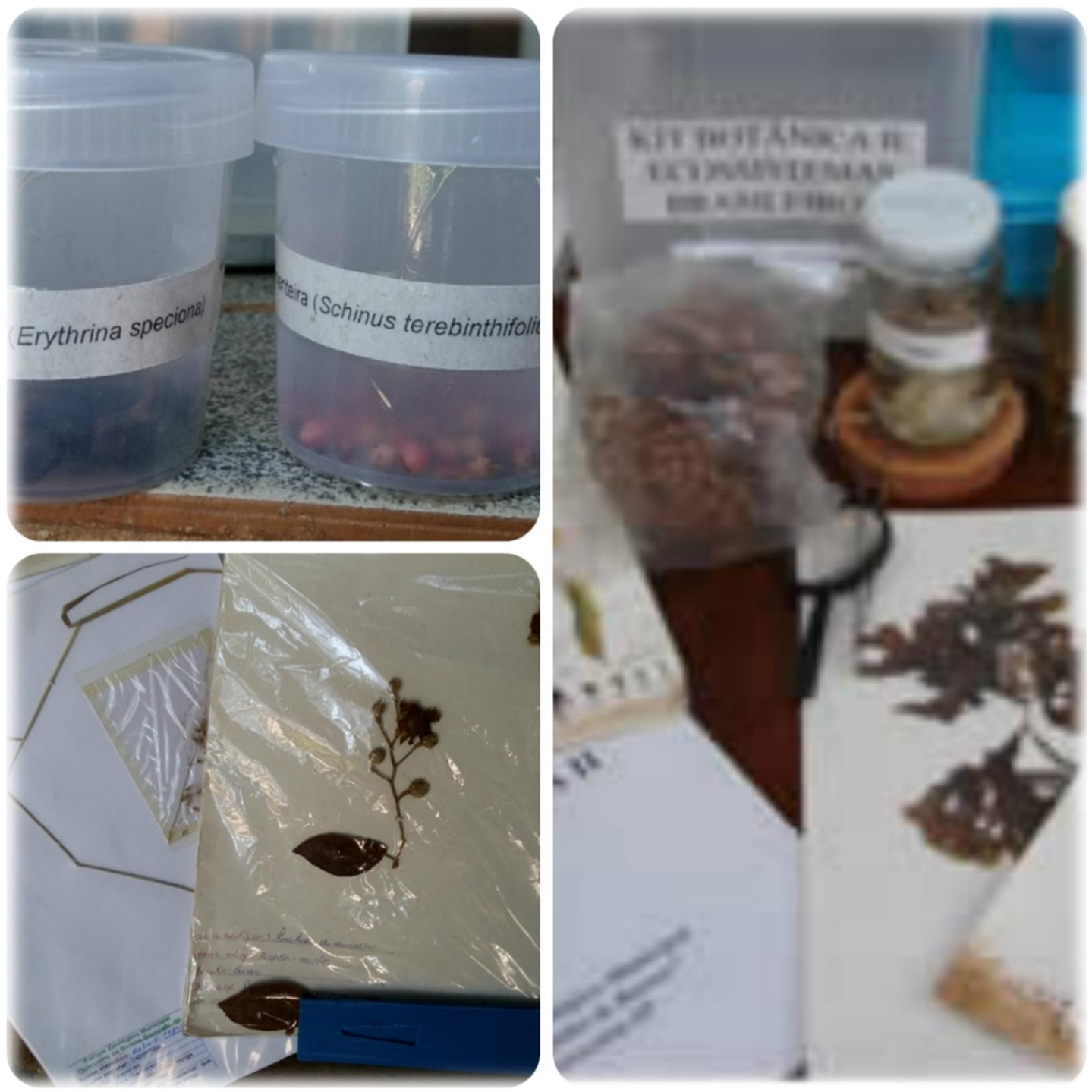

\section{Animais}

6. Peixes do Rio Sorocaba (Figura 8): Dentro da caixa grande existem 8 espécies de peixes do Rio Sorocaba acondicionadas em frascos de vidro com álcool 70\% e um manual para o 
professor. Nem todos os materiais indicados no site do Zôo estão presentes no kit conforme nossas observações. Os itens da caixa registrados por nós foram:

- Animais em via úmida: caborja, pirambeba, cascudo, canivete, lambari, coridora, traíra, peixe-cadela.

- Outros: manual para o professor.

Figura 8: Objetos constituintes do kit Peixes do Rio Sorocaba Fotos de Márcia Fernandes Lourenço
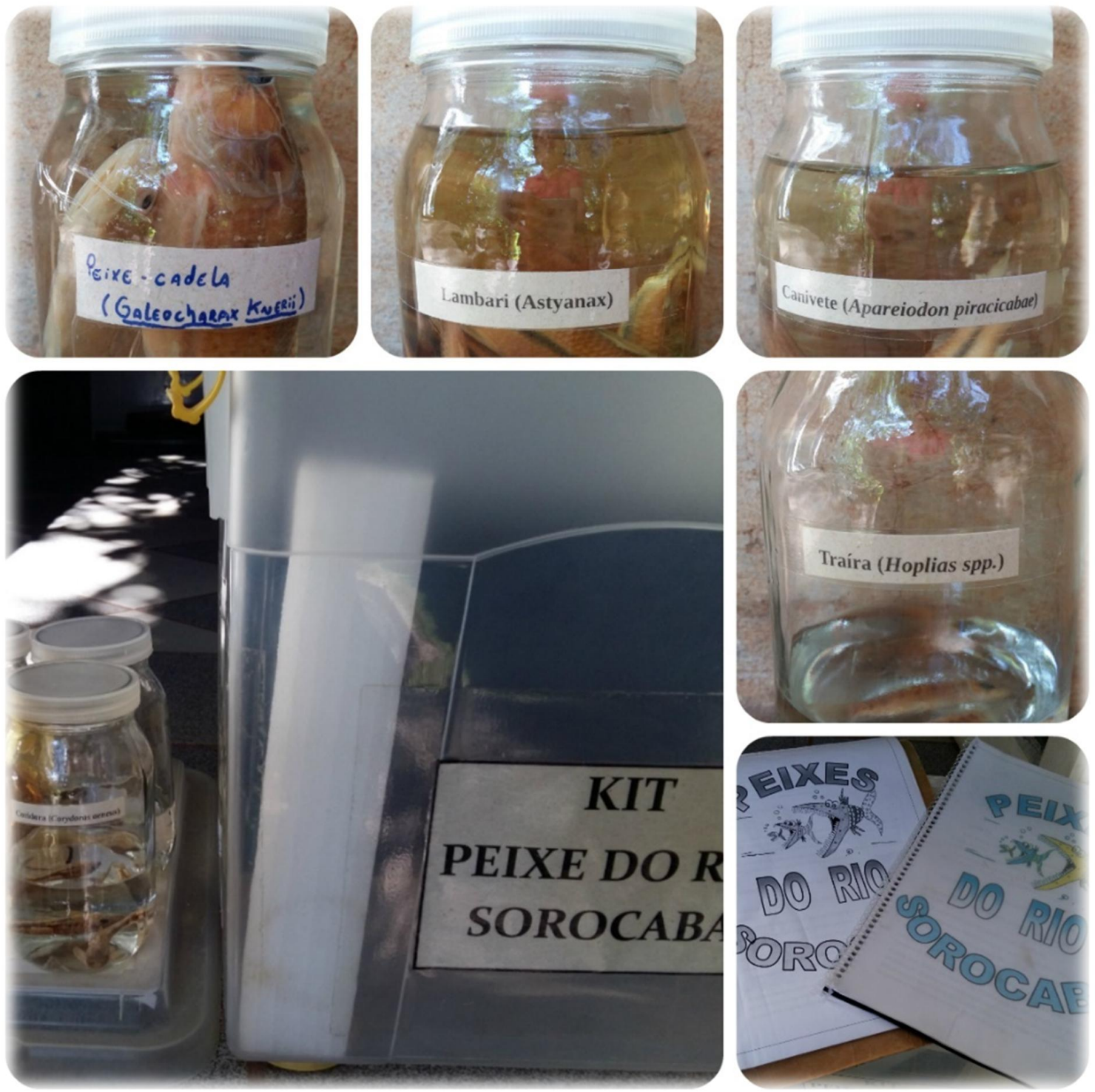
7. Artrópodes (Figura 9): No interior da caixa grande existem 4 caixas pequenas contendo animais em via seca, frascos de vidro com animais em via úmida (álcool 70\%), animais em resina, lupas manuais, sem apostila ou lista de materiais. O kit observado por nós foi enriquecido pela equipe do Zôo, com outros espécimes animais além dos animais incluídos em resina, como é apresentado no site do zoológico. Além disso, o nome do kit no site é "Desvendando os artrópodes" e o que observamos nas nossas coletas é “Artrópodes".

- Animais em via seca: besouro, abelha, carrapato, mariposa e casulo (pupa).

- Animais em via úmida: aranha-de-teia (Nephila sp), escorpião-vinagre (Telyphonida), armadeira (Phoneutria sp), caranguejeira (Lasiodora parahybana) e aranha-marrom (Loxoceles gaucho).

- Animais incluídos em resina: escorpião, marimbondo, besouro, lacraia e besouro.

- Outros: 2 lupas manual.

Figura 9: Objetos constituintes do kit Artrópodes Fotos de Márcia Fernandes Lourenço
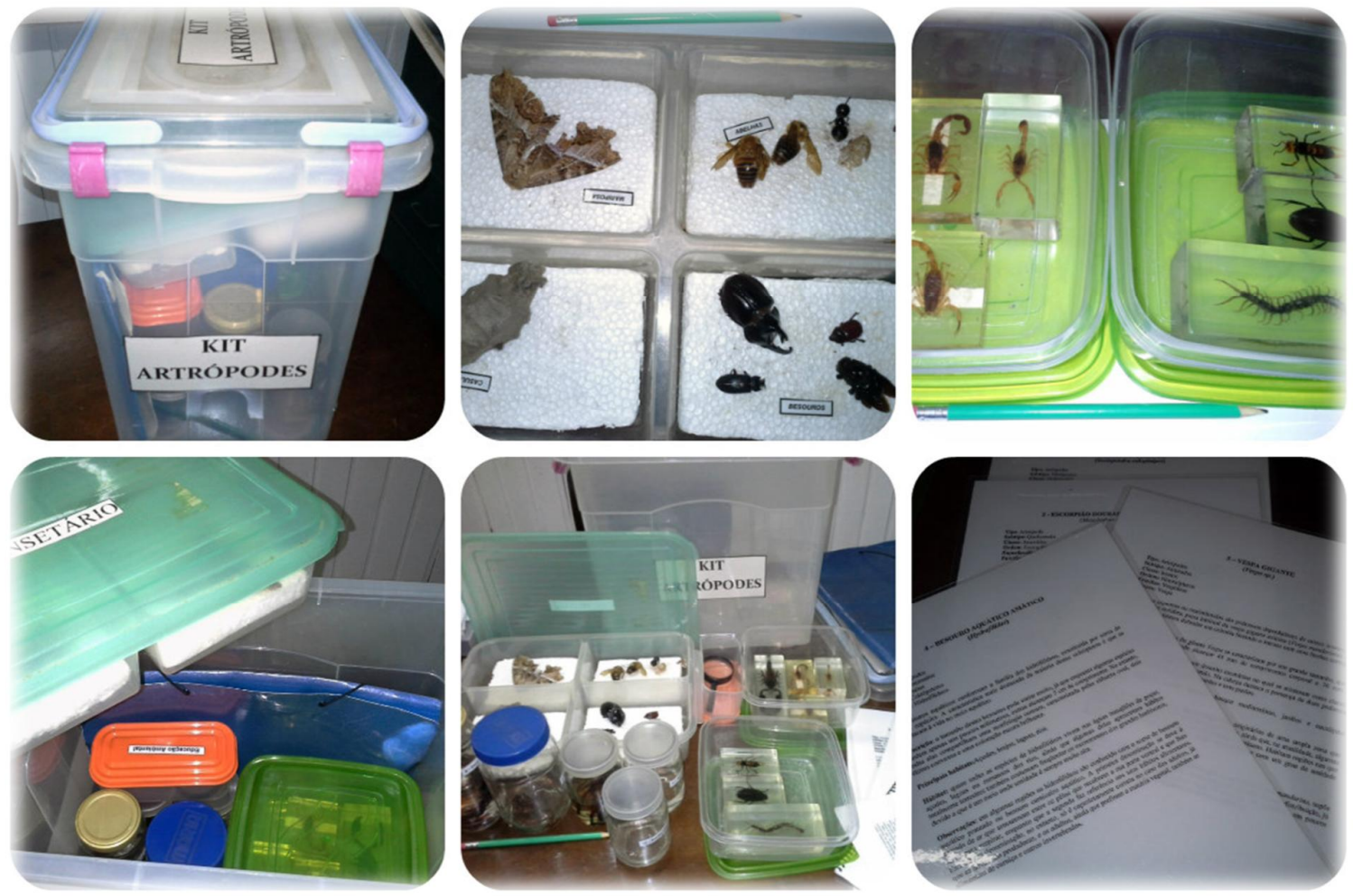
8. Aves I (Figura 10): Dentro da caixa maior estão 3 caixas menores identificadas como Caixas A, B e C contendo partes de animais, penas, ovos e regurgito de coruja suindara. Outras partes estão soltas na caixa maior. Dois dos materiais do kit não estão na lista de materiais e não estão identificados. Há também livros sobre aves da Amazônia (Aves da Amazônia, Enzo Enrico, Ed. Aves e fotos) e para colorir (sem autoria). Os materiais do kit observados por nós são:

- Partes de animais em via seca: patas de coruja e seriema, crânios de biguá, arapapa, arara, jaburu e de irerê, 2 patas de ave não identificadas, bico de tucano, asa de garça e osso da perna de ema.

- Penas e ovos: pena de gavião e ovo de avestruz.

- Regurgito de coruja suindara: restos de aves e mamíferos, besouro indicado como principal alimento da coruja.

- Outros: 1 livro de aves para colorir, 1 livro sobre aves da Amazônia.

Figura 10: Objetos constituintes do kit Aves I

Fotos de Márcia Fernandes Lourenço
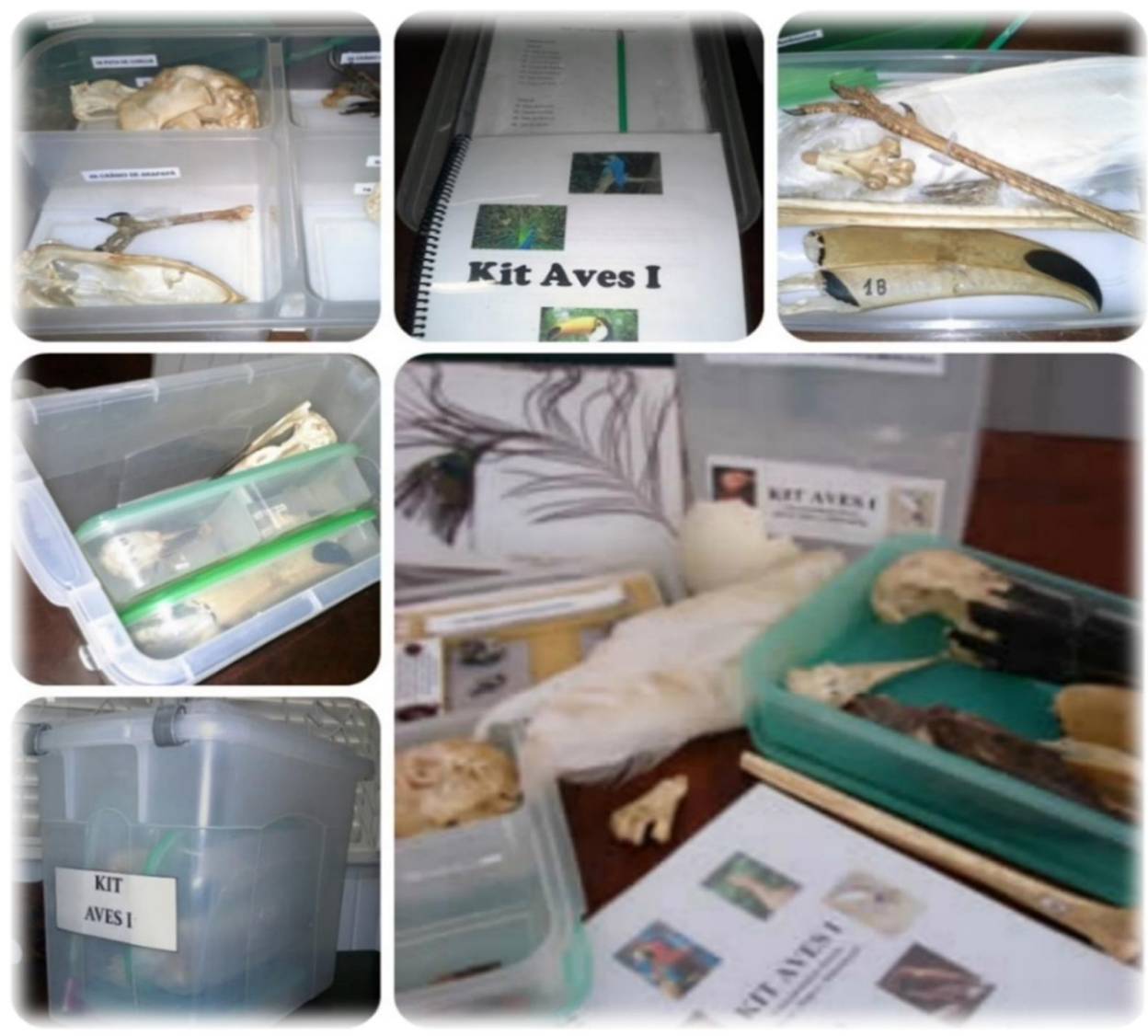
9: Aves II (Figura 11): No interior da caixa grande existem outras 4 menores com partes de animais em via seca, 1 saco plástico com ninhos, binóculo e livros com informações gerais sobre aves, modo de vida, alimentação, reprodução, habitat (Beija-flores. Coleção ECO. Ed. Melhoramentos; O Martim-pescador, Coleção Estrela-d'alva, Ed. Ática; Pássaros. Coleção Truques, Artes e Manhas dos Animais, Ed. Melhoramentos; Aves da cidade, E. Hofling e V. L. Imperatriz-Fonseca, IB/USP), não há manual para o professor. Soltas na caixa, duas patas e um ovo de ema. Os materiais observados também não coincidem com os descritos no site do zoológico.

- Partes de animais em via seca: bicos de arara e gavião, patas de garça e gavião.

- Animal em via seca: pomba.

- Ninhos: ninho de tico-tico, ninho de rolinha.

- Ovo: ema.

- Outros: 3 livros infanto-juvenis sobre pássaros em geral, beija-flores e martinpescador.

Figura 11: Objetos constituintes do kit Aves II Fotos de Márcia Fernandes Lourenço
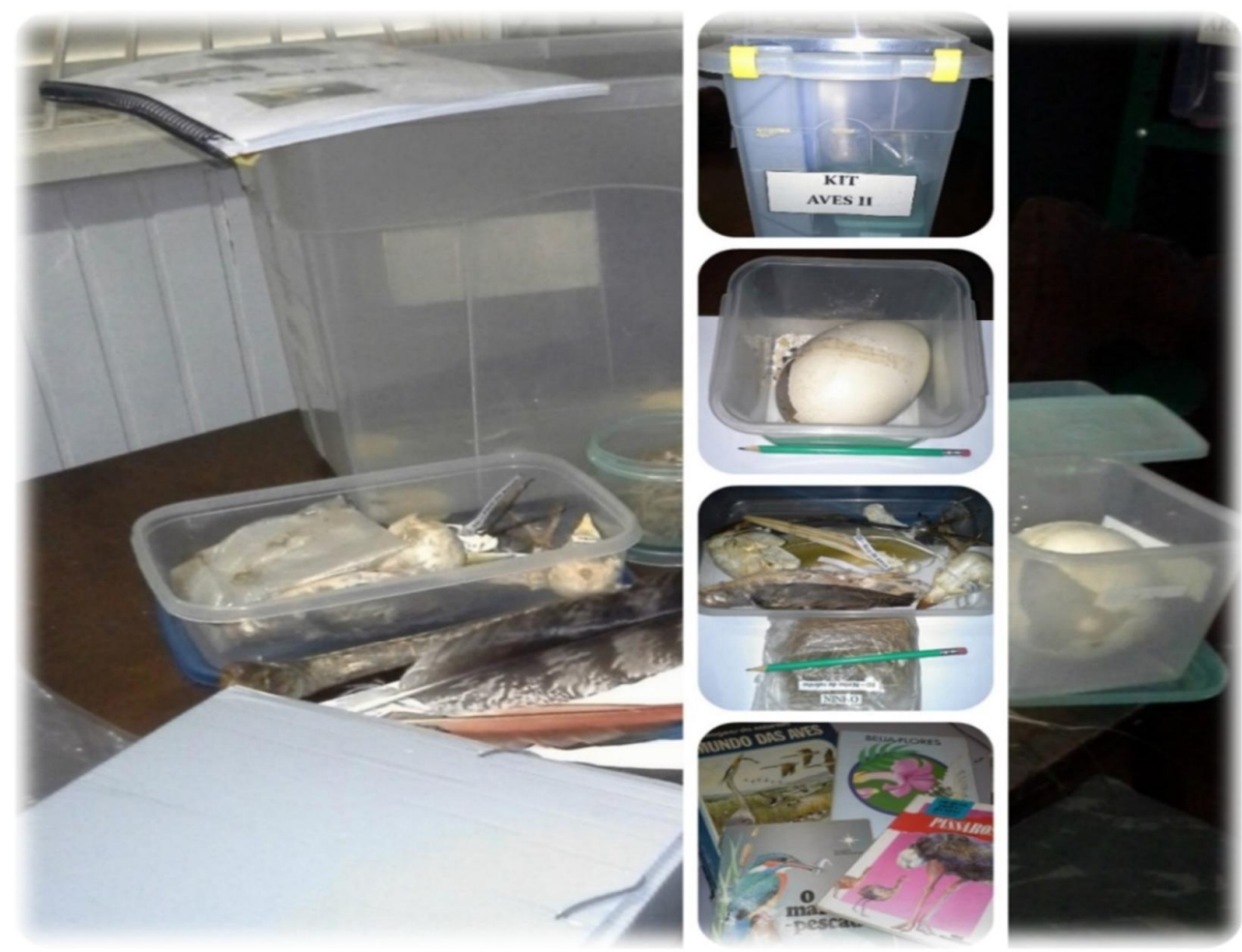
10. Anfíbios (Figura 12): O conjunto de materiais é formado por uma pasta com manual do professor, jogo de tabuleiro (de autoria da equipe do Zôo de Sorocaba), DVDs com imagens de anfíbios e conteúdo biológico sobre o grupo, folhas de sulfite soltas com curiosidade sobre anfíbios e letras de músicas sobre o tema (sem autoria), livro Filhotes - Rã, Ed. Melhoramentos e caixa plástica com modelos plásticos de anfíbios e animais originais. Observamos que neste kit não constam todos os materiais indicados no site do zoológico. Os itens que compõem este kit, segundo nossas observações são:

- Animais em via úmida: cobra-cega, sapo-cururu, sapo-ferreiro, rã-do-cerrado, sapode-cruz, rã-paulistinha, perereca-minuta.

- Outros: pranchas com imagens da diversidade de anfíbios, DVDs com imagens e conteúdo biológico sobre o tema, caixa plástica com modelos de animais de plástico, manual para o professor, jogo de tabuleiro, folhas de sulfite com letras de músicas e curiosidades sobre anfíbios.

Figura 12: Objetos constituintes do kit Anfíbio Fotos de Márcia Fernandes Lourenço

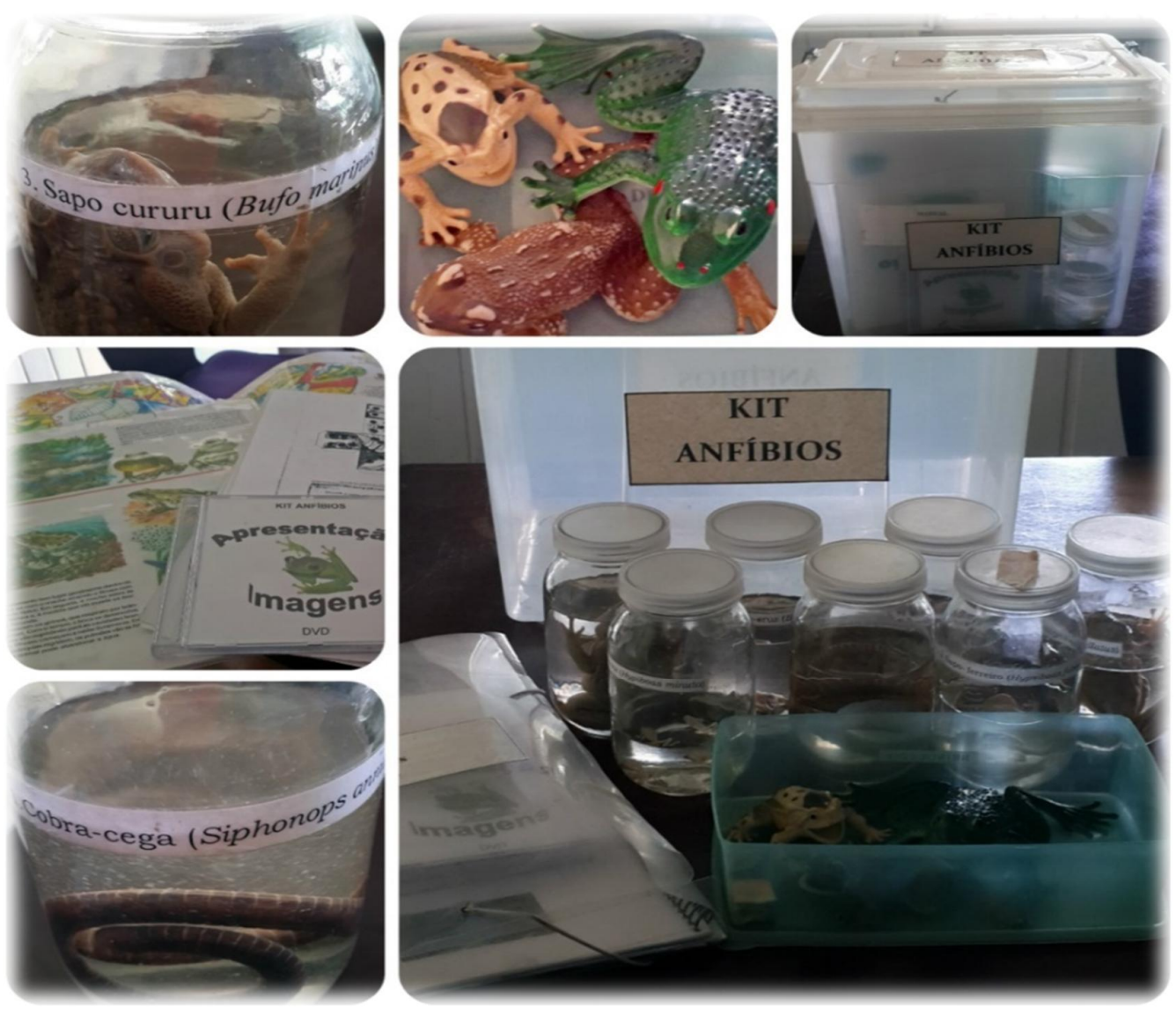


11. Dinossauros (Figura 13): O material contém bibliografia (Apostila do Instituto de Geociências da USP), quebra-cabeça (Coleção como montar? Ed. Trexba), livro (Dinossauro, meu primeiro livro, Alex Frith, Ed USBORNE) e réplicas de fósseis. Este kit não é apresentado no site do zoológico. Segundo nossas observações este kit é composto de:

- Réplicas de fósseis: coral rugoso, garra de oviraptor, folha de planta, equinoderma, ramo de planta, placa de gliptodonte, tubos de poliquetas, amonóide, dente de tubarão gigante, braquiópode, dente de preguiça-gigante, dente de tigre-dente-de-sabre, trilobita, fauna de ediacara.

- Outros: quebra-cabeça do T. rex, pôster de dinossauros, apostila do Instituto de Geociências da USP e livro sobre dinossauros.

Figura 13: Objetos constituintes do kit Dinossauros Fotos de Márcia Fernandes Lourenço
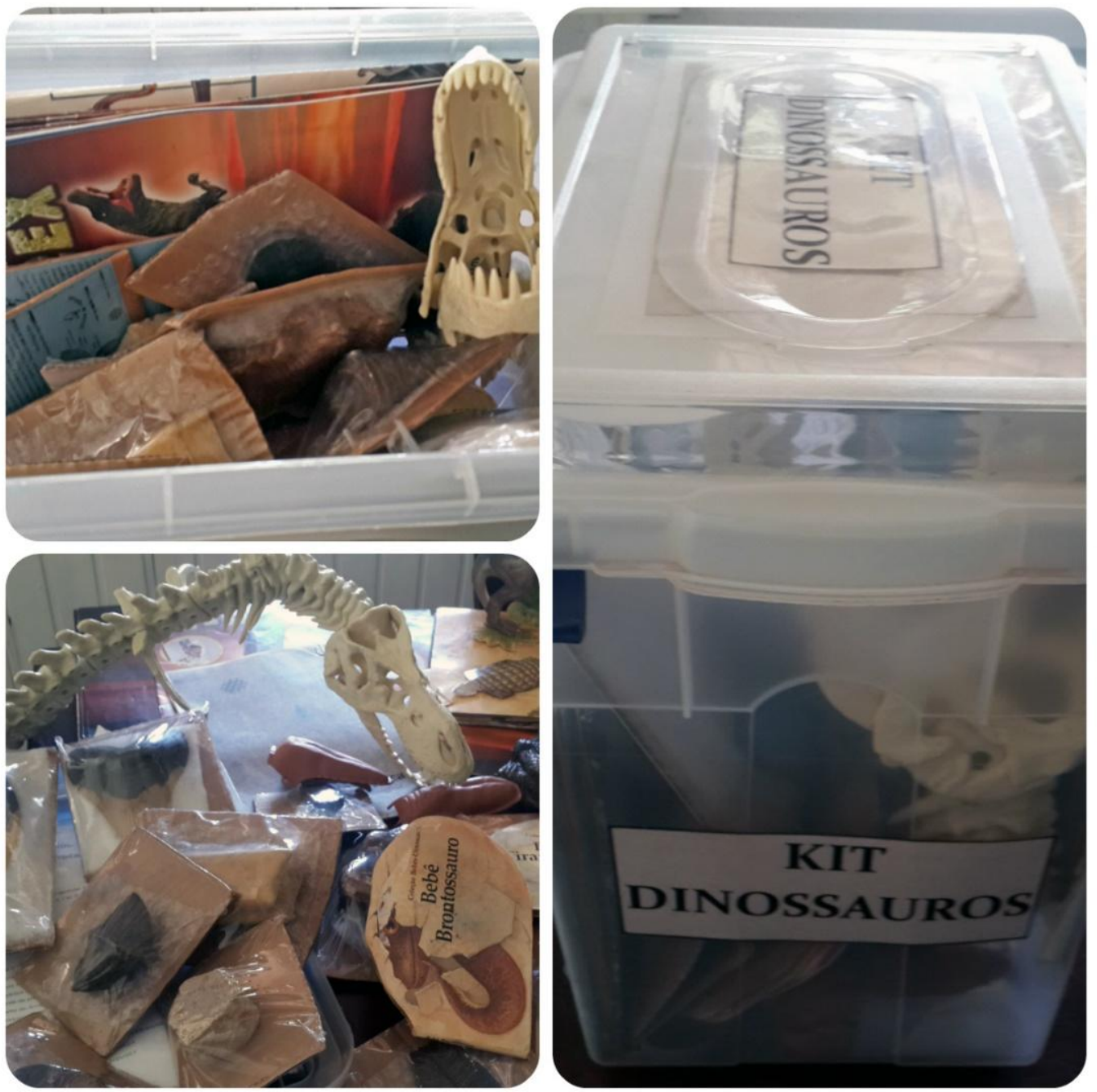
12. Mamíferos I (Figura 14): Existem neste kit materiais bibliográficos para consulta (Baleias - Gigantes do mar / National Geographic Society - Klick Editora; Mamíferos - Truques, artes e manhas dos animais, Leonora e Arthur Hornblow, Ed. Melhoramentos; O tamanduá, Maurício Negro, Global Ed.; Vida na selva, Alicia Zadrozny, Texto editores), moldes de pegadas, animais conservados e partes deles em via úmida e seca. Nem todos os materiais descritos no site do zoológico estão no kit, segundo nossas observações. Abaixo o conteúdo deste kit.

- Animais em via úmida: feto de veado, morcego-de-cara-branca, morcego-cauda-derato.

- Partes de animais em via seca: casco de tatu, crânios de tamanduá-bandeira, golfinho, e veado, chifre de veado.

- Moldes de pegadas: anta e veado.

- Outros: manual para o professor e dois livros infantis sobre tamanduá e mamíferos em geral.

Figura 14: Objetos constituintes do kit Mamíferos I Fotos de Márcia Fernandes Lourenço
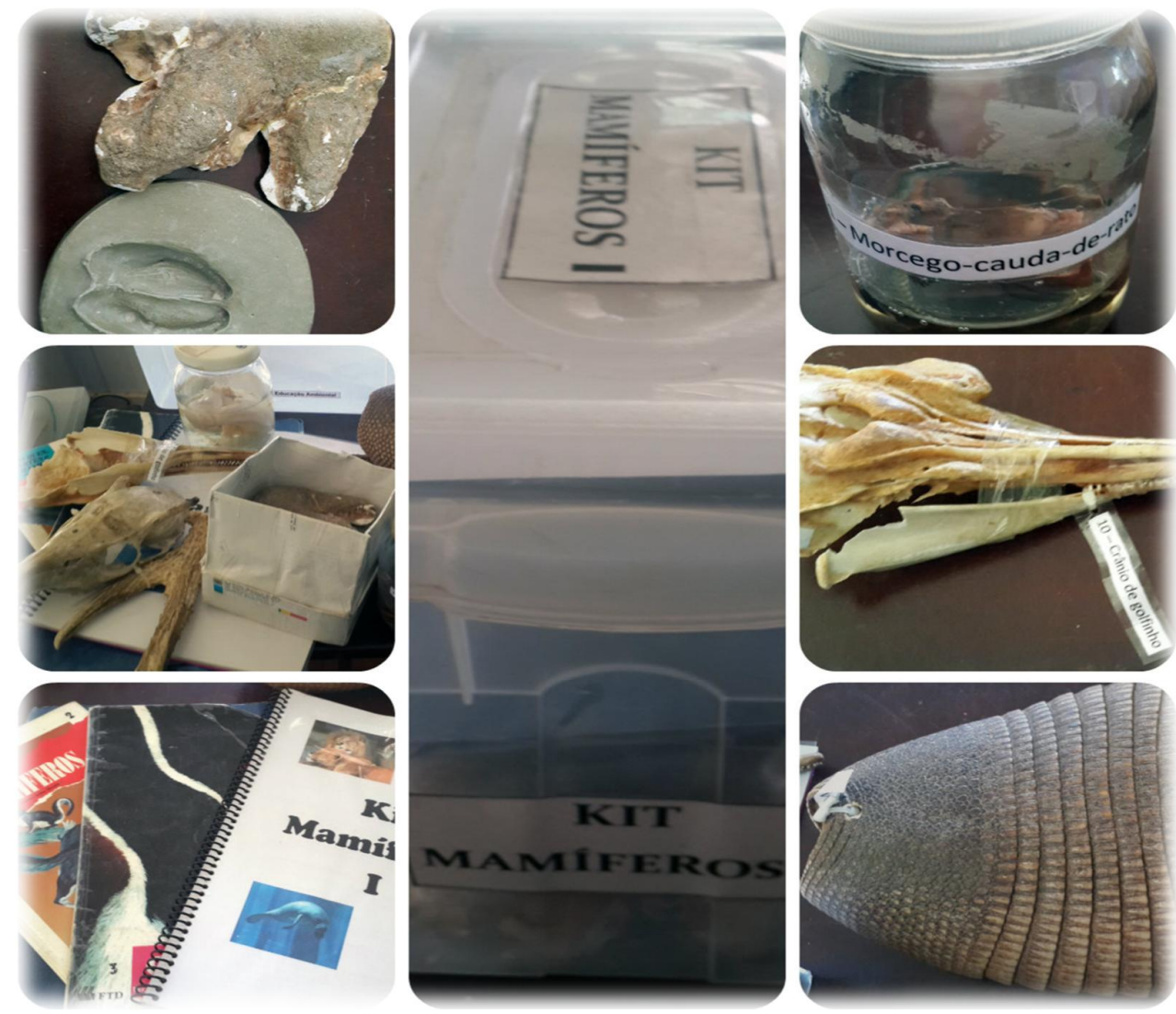
13. Mamíferos II (Figura 15): No interior da caixa maior existem frascos menores com as partes dos animais em seu interior, manual para o professor e moldes de patas.

- Parte de animais em via seco: crânios de leão, cachorro-do-mato, bugio e sagui-dotufo-branco, espinhos de ouriço.

- Moldes de pegadas: mão-pelada e gato-do-mato.

- Outros: manual para o professor.

Figura 15: Objetos constituintes do kit Mamíferos II Fotos de Márcia Fernandes Lourenço
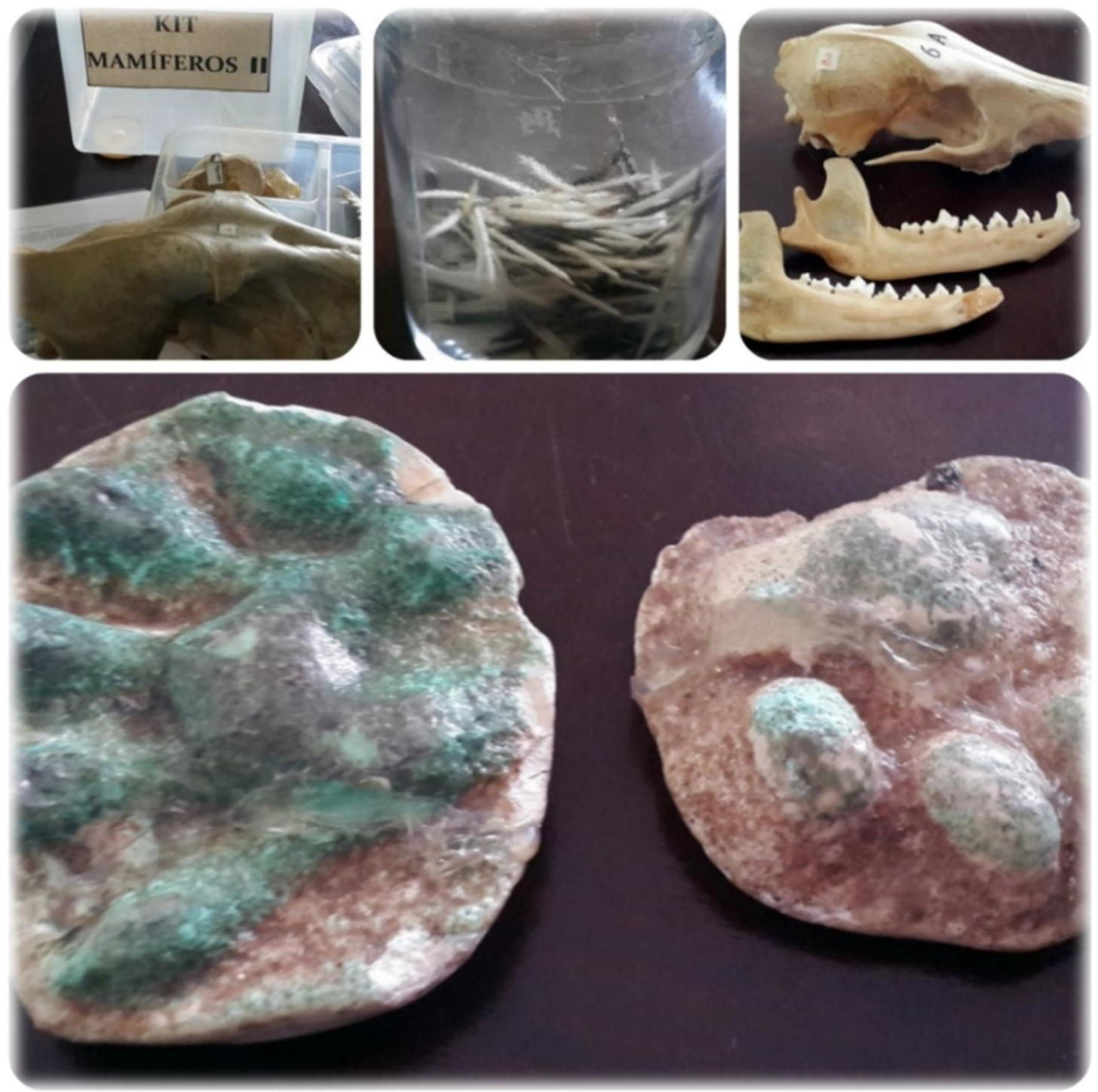
14. Répteis I (Figura 16): Neste kit são apresentados os quelônio e os crocodilianos. No interior da caixa grande estão 2 caixas plásticas menores com partes de animais em via seca e 2 frascos com álcool $70 \%$ com os animais em via úmida, livros sobre o grupo (Tartarugas e Cágados, Barreto, S., Ed. Melhoramentos; Répteis nas pontas dos dedos, Judy Nayer e George Goldberg) e manual do professor. O site do zoológico indica a presença de uma apostila do Instituto Butantã que não foi localizada por nós. Os itens observados por nós foram:

- Partes de animais em via seca: crânios de jacaré-de-papo-amarelo e tartaruga, casco de cágado, couro de jacaré.

- Animais em via úmida: jabuti, (Chelonoidis) e cágado-pescoço-de-cobra (Hydromedusa tecifera)

- Outros: manual para o professor e livros sobre o grupo.

Figura 16: Objetos constituintes do kit Répteis I Fotos de Márcia Fernandes Lourenço

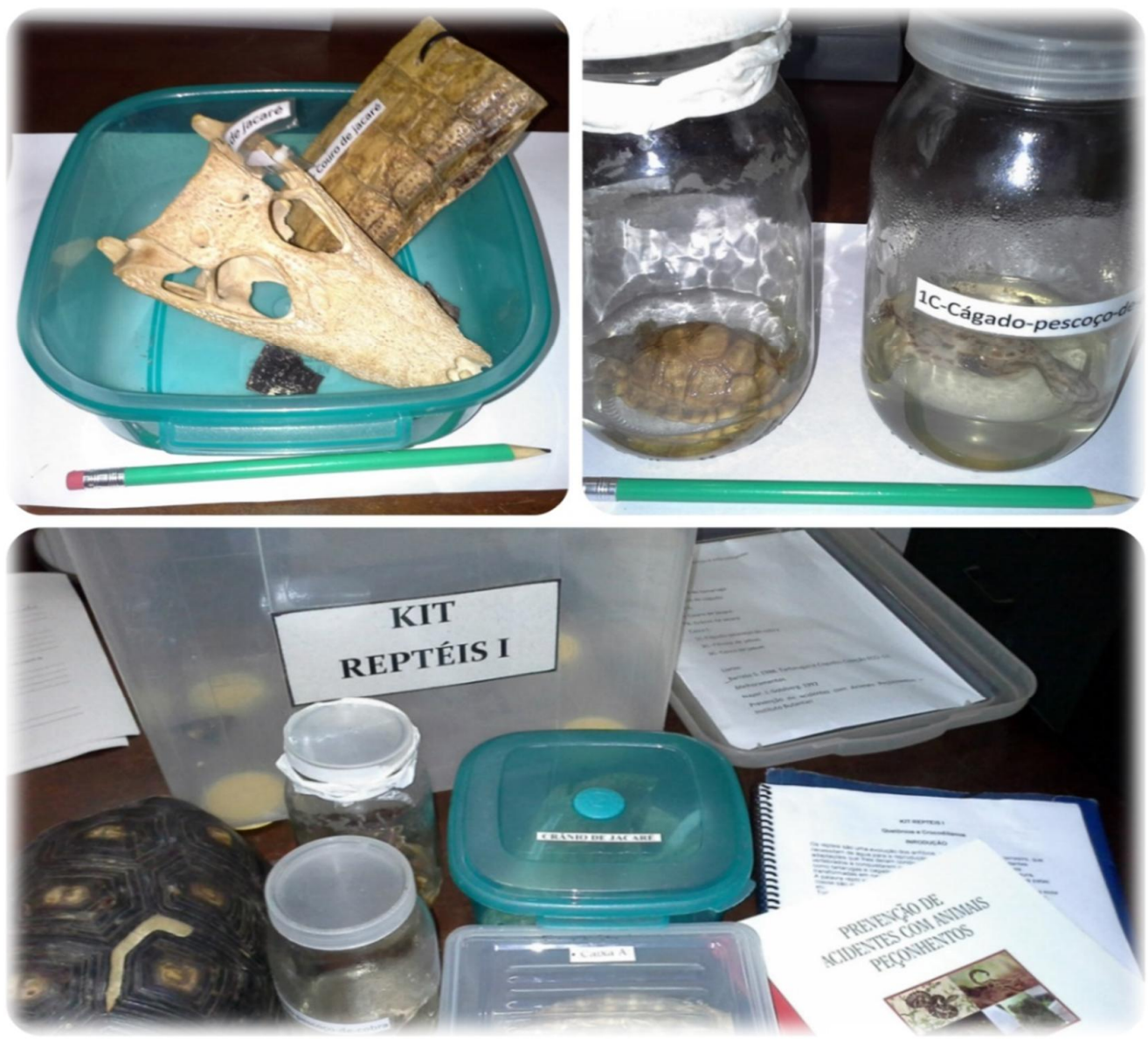


15. Répteis II (Figura 17): Neste kit são apresentados os grupos dos lagartos e das serpentes. Existem animais em via seca e úmida abrigados em caixas menores e frascos de vidro, modelos, livros (Série Didática - Instituto Butantã; Répteis - Truques, artes e manhas dos animais, Ed. Melhoramentos; Répteis nas pontas dos dedos (Judy Nayer); Prevenção de acidentes com animais peçonhentos, Instituto Butantã) e manual para o professor. Todos os objetos descritos no site do zoológico foram observados por nós. Os materiais do kit são descritos abaixo:

- Animais em via úmida: lagarto, cobra-de-duas-cabeças, cobra-dormideira, jararaca com bicefalia, falsa coral.

- Partes de animais em via úmida: órgão genital de cascavel, ovos de serpente.

- Animais em via seca: peles de lagarto e serpente, costela e vértebras de serpente.

- Modelos: 2 modelos de cabeça de serpente em resina.

- Outros: manual para o professor, Série Didática do Instituto Butantã e Livros sobre lagartos e serpentes.

Figura 17: Objetos constituintes do kit Répteis II Fotos de Márcia Fernandes Lourenço
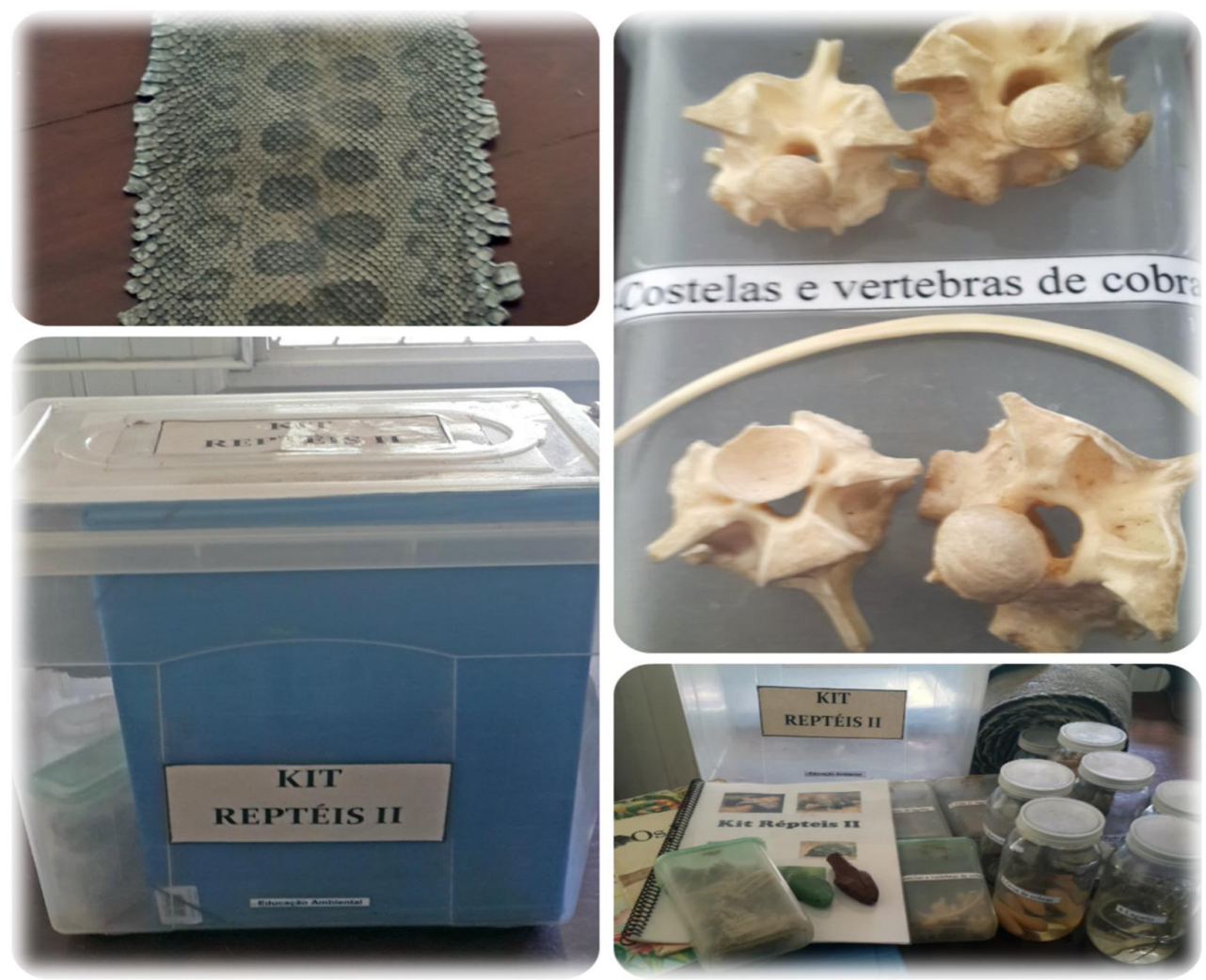
16. Animais Peçonhentos (Figura 18): Dentro da caixa maior existem 6 frascos de vidro com os animais conservados em via úmida e o manual para o professor. $\mathrm{O}$ kit identificado nas nossas observações como "Animais Peçonhentos" não existe no site do zoológico. Os materiais do kit observado por nós são:

- Animais em via úmida: aranha-armadeira, aranha-caranguejeira, escorpião-marrom, escorpião-amarelo, cobra-coral e cascavel.

- Outros: manual para o professor.

Figura 18: Objetos constituintes do kit Animais Peçonhentos Fotos de Márcia Fernandes Lourenço
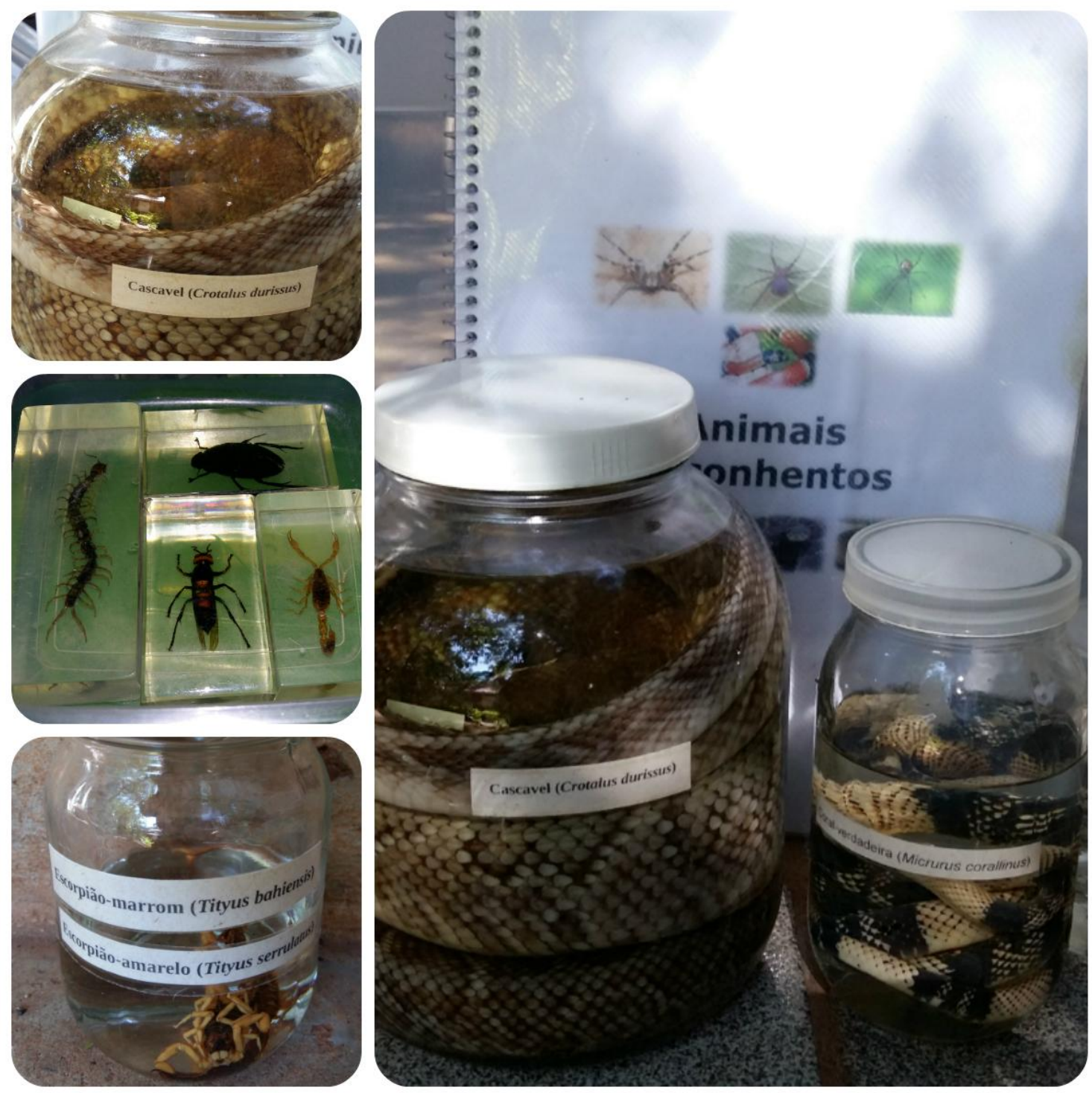


\section{Estruturas adaptativas nos animais}

17. Defesa (Figura 19): O kit contém partes de animais referentes à defesa, esconderijo, disfarce, aposematismo e manual do professor com conteúdo temático e com algumas orientações de uso do material. Nem todos os materiais citados no site do zoológico estão presentes na caixa. Os itens que compõem este kit, segundo nossas observações são:

- Animais em via úmida: serpente-dormideira e calango-das-pedras.

- Animais em via seca: bicho-pau, taturanas, filhote de tatu-galinha e de jabuti, concha.

- Partes de animais: ferrão de arraia, espinhos de ouriço, crânio de cascavel, espinhos de porco-espinho.

- Outros: manual para o professor e joaninha de pelúcia.

Figura 19: Objetos constituintes do kit Defesa Fotos de Márcia Fernandes Lourenço
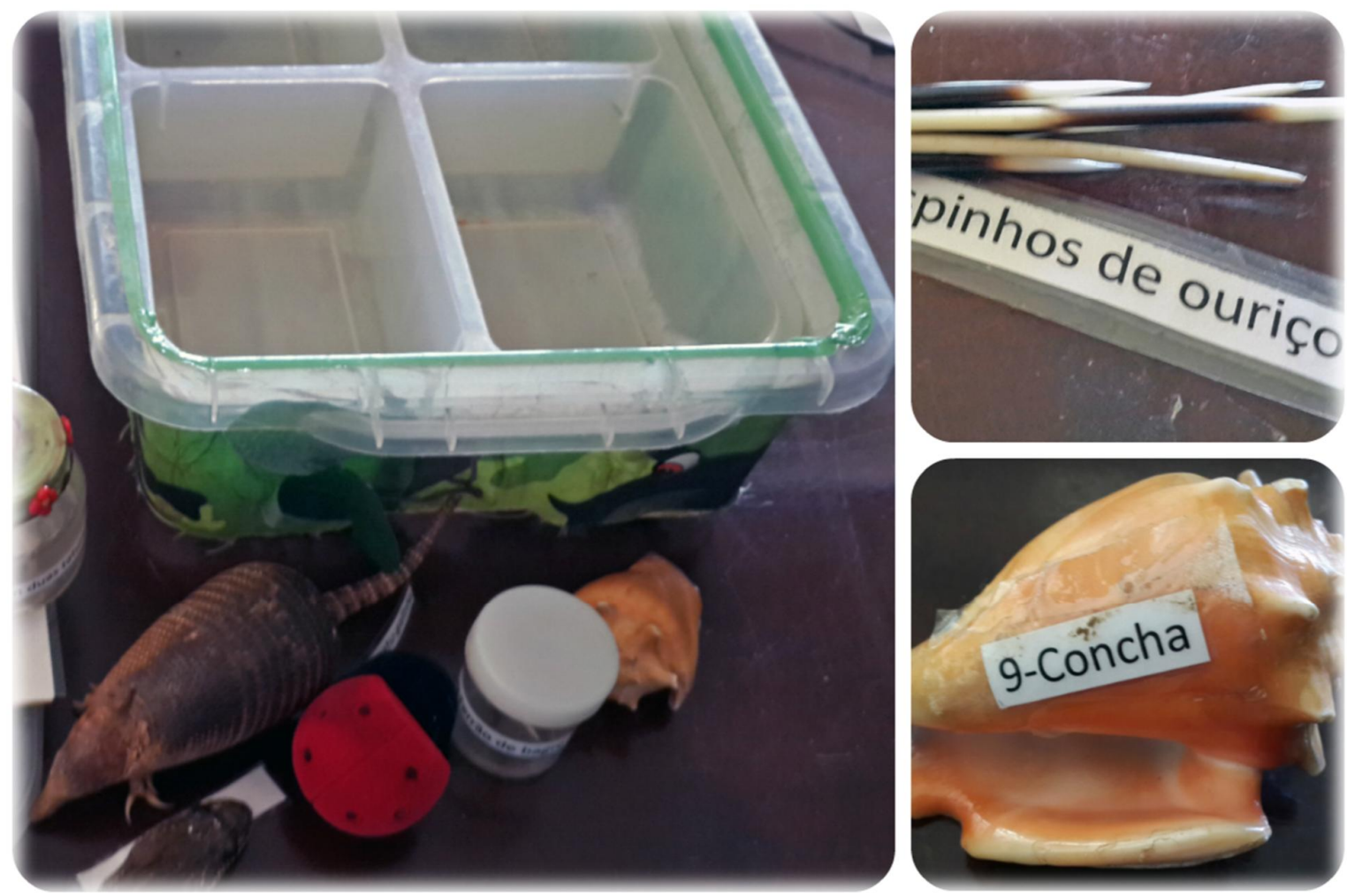
18. Alimentação (Figura 20): Este kit contém partes de animais referentes à alimentação. Algumas peças menores estão abrigadas em frascos plásticos. O manual para o professor contém dados de biologia, aspectos da fisiologia da alimentação e orientações de uso do material. Nem todos os materiais citados no site do zoológico estão presentes no kit. Os itens que compõem este material, segundo nossas observações, são:

- Animais em via seca: estrela-do-mar.

- Partes de animais em via seca: arcada de tubarão, crânios de cutia, papagaio, tamanduámirim, mão-pelada, flamingo, ganso, gaviãozinho e bugio, dentadura artificial humana, 3 dentes de onça, mandíbula de arraia, cabeça de socó e tucano.

- Outros: manual para o professor.

Figura 20: Objetos constituintes do kit Alimentação Fotos de Márcia Fernandes Lourenço
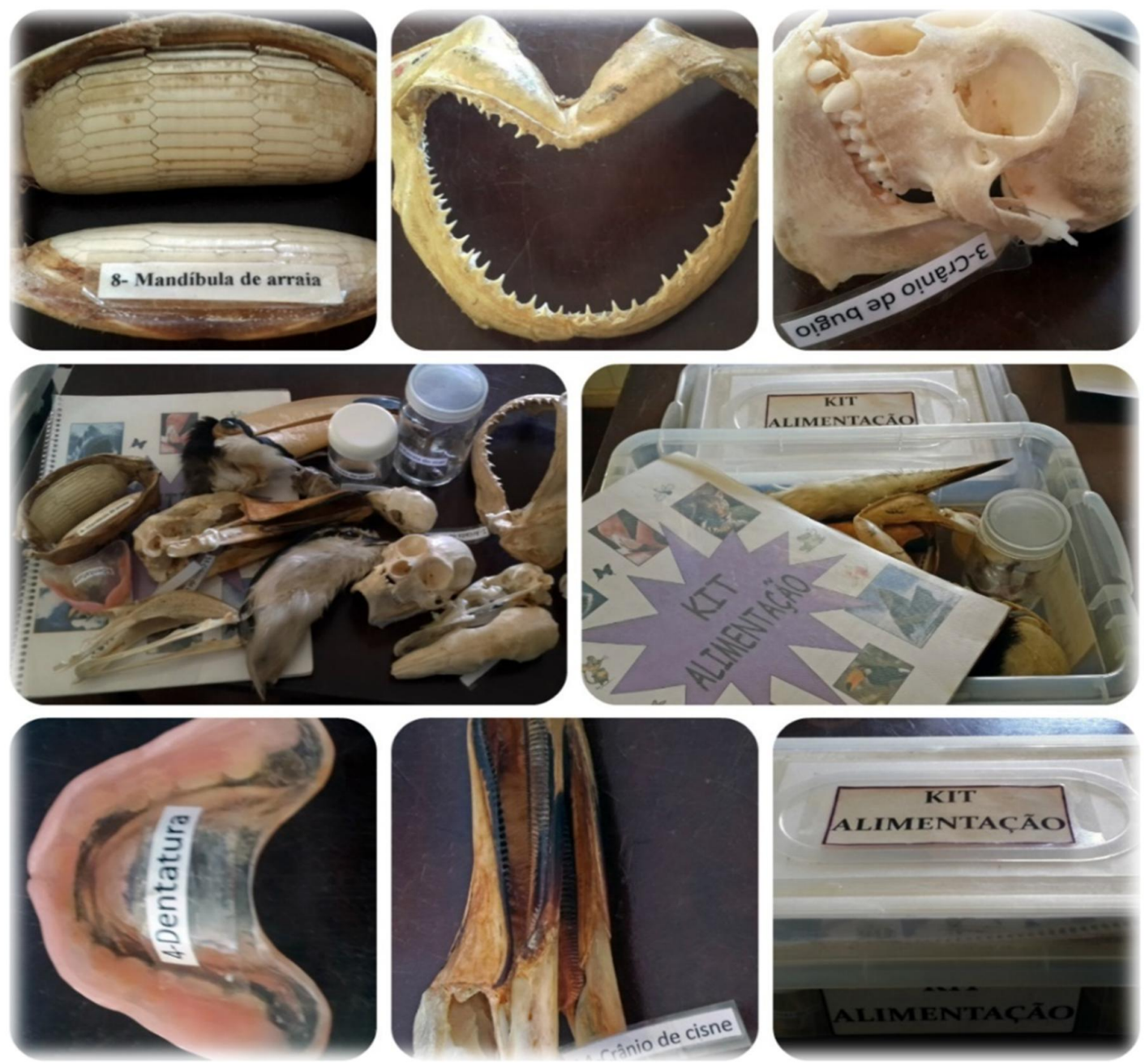
19. Locomoção (Figura 21): Contém partes de animais referentes à locomoção e manual do professor com conteúdo e orientações. A lista de material do kit observado não é a mesma da lista da caixa e nem do site. Os itens que compõem este kit, segundo nossas observações, são:

- Animais em via seca: morcego.

- Partes de animais em via seca: pata de cisne, suindara e ema, pata e asa de araracanindé, mão de macaco-prego e ouriço, asa de jaçanã.

- Outros: manual para o professor.

Figura 21: Objetos constituintes do kit Locomoção Fotos de Márcia Fernandes Lourenço
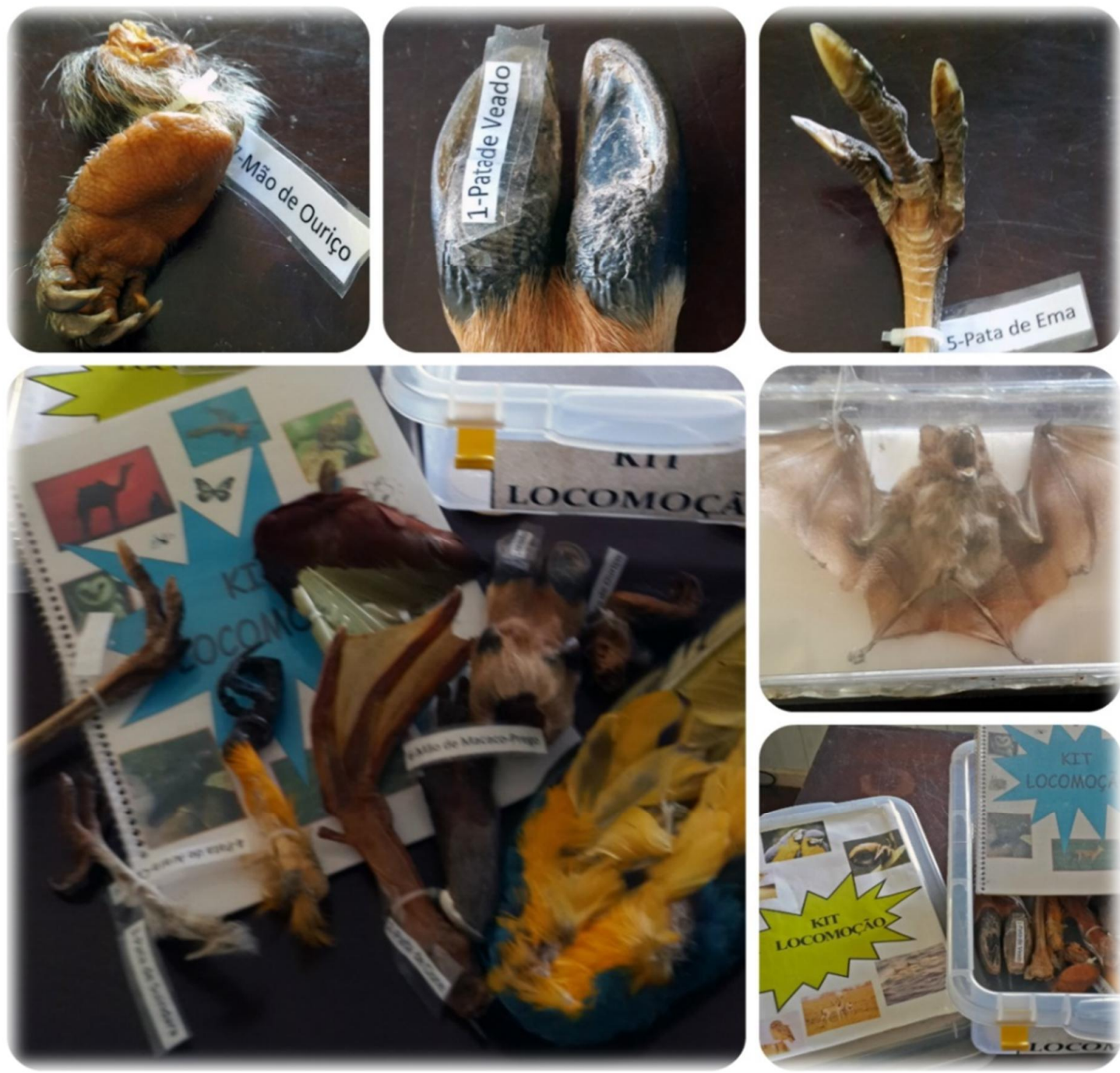
20. Reprodução (Figura 22): No interior da caixa grande existem caixas plásticas menores e frascos de vidros com espécimes conservadas, cds, penas, ovos e manual. Neste kit também não existem todos os objetos indicados no site do zoológico. Os itens que compõem este kit, segundo nossas observações são:

- Animais em via seca: casal de azulão taxidermizado.

- Ovos e penas: pena de pavão, ovos de serpente, arraia e jabuti.

- Outros: CD de canto das aves brasileiras e manual para o professor.

Figura 22: Objetos constituintes do kit Reprodução Fotos de Márcia Fernandes Lourenço

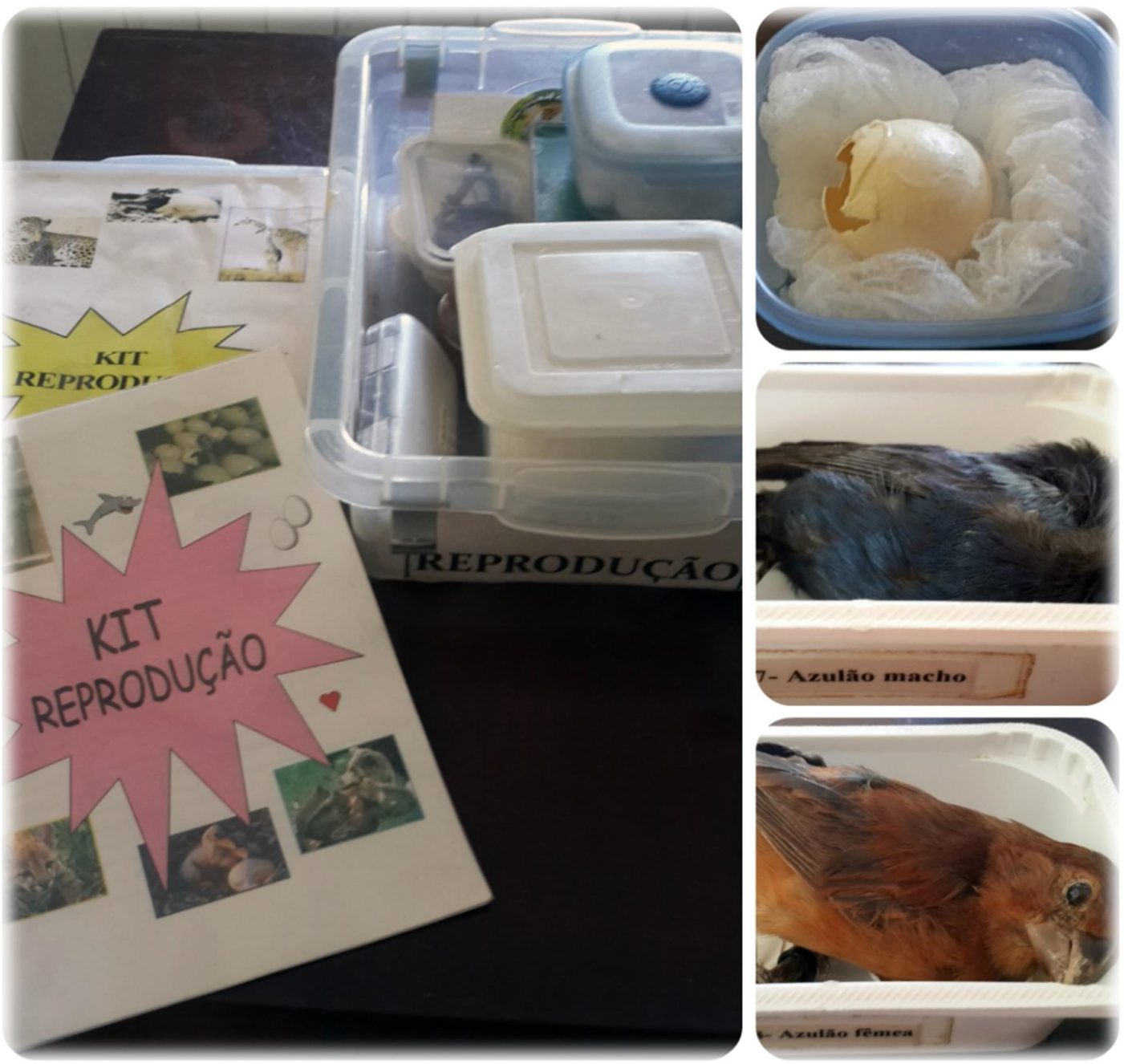




\section{Saúde}

21. Parasitose humana (Figura 23): No interior da caixa existem pastas com diversos tipos de materiais complementares (Guia dos parasitas: $1 \mathrm{G}$ - prancha e Doenças negligenciadas, IPEA), uma fita VHS (Convivência) e manual para o professor, além dos animais originais. Uma das pastas contém imagens dos parasitas vistas ao microscópio para observação nas lâminas, mas elas não estão no kit. A comparação do site do zoológico e nossas observações não coincidem.

- Animais em via úmida: carrapato, caramujo da esquistossomose, nematódeo de tigre, ancilóstomos, proglotes de Taenia solium, lombriga, nematódeo de primata.

- Outros: fita VHS, manual para o professor, cartões com o ciclo de vida dos parasitas, 3 pastas com transparências para retroprojetor com ilustrações e ciclos de vida (sem autoria indicada).

Figura 23: Objetos constituintes do kit Parasitose Humana Fotos de Márcia Fernandes Lourenço
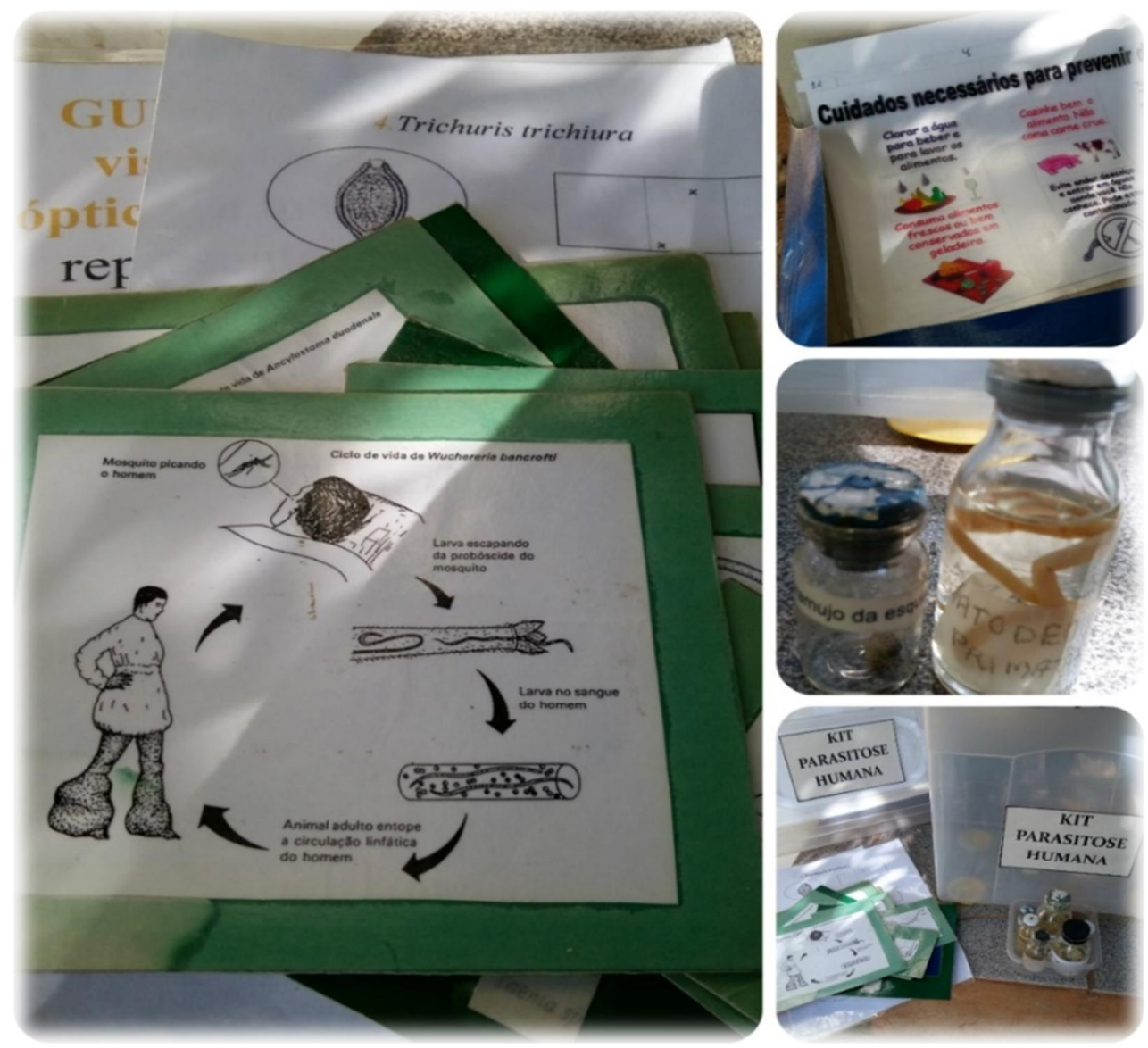
22. Lixo I (Figura 24): Todos os materiais estão abrigados em pequenas caixas plásticas no interior da maior. Não há indicação de como utilizar as substâncias químicas presentes no kit. Este kit não consta da lista do site do zoológico.

- Materiais diversos: 1 caixa com plástico picado, 1 caixa com borracha reciclada, 1 caixa com fibra de coco e outra com xaxim, 1 peneira plástica, frascos de vidro com areia, barrilha, óxido de alumínio, silicato de alumínio, 1 barra de sabão ecológico, 1 recipiente plástico com material não identificado, 1 envelope com amostras de papel reciclado, 1 jogo, modelo de telha feita com tubo de pasta de dente.

Figura 24: Objetos constituintes do kit Lixo I

Fotos de Márcia Fernandes Lourenço
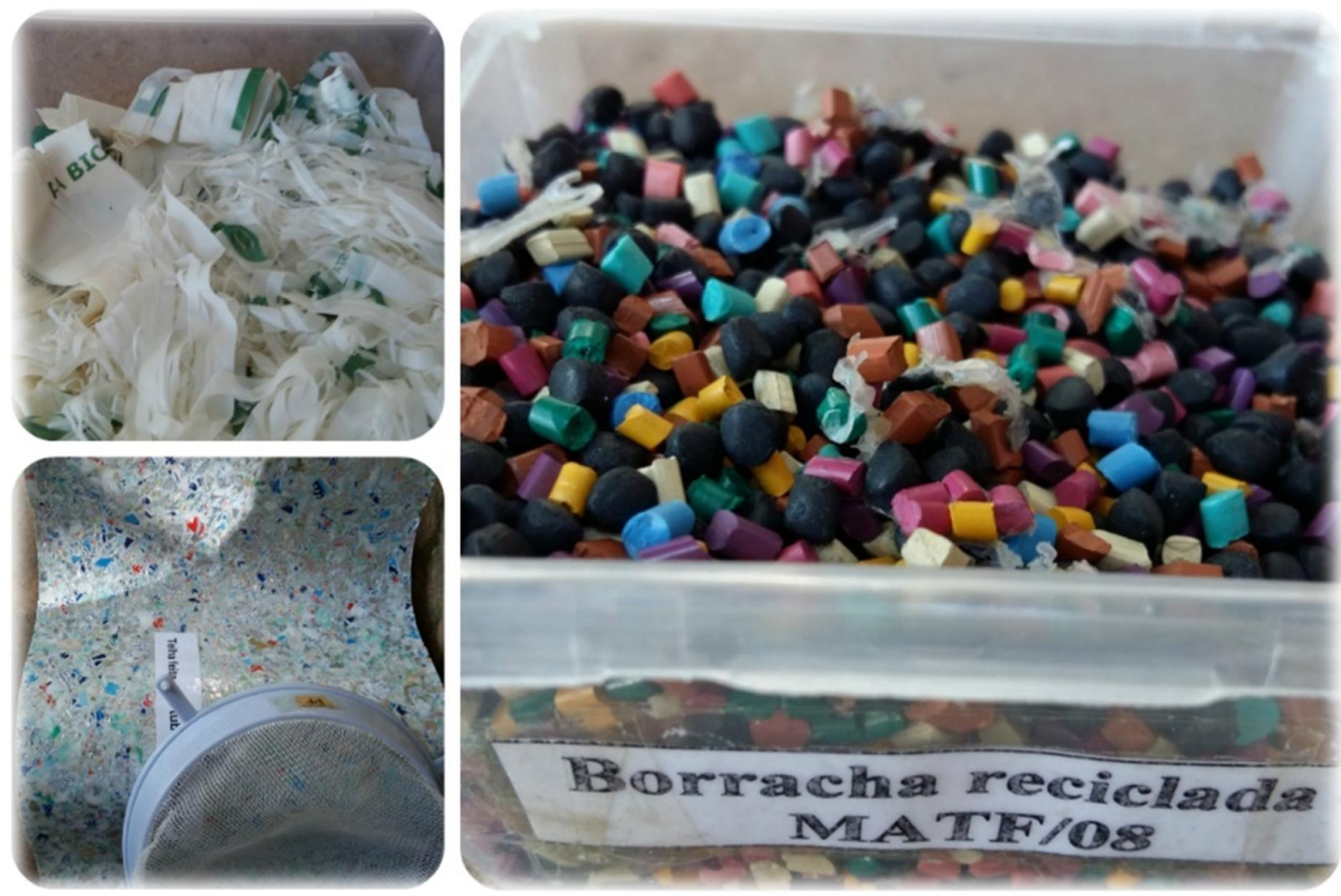

23. Lixo II (Figura 25): Dentro da caixa grande existe uma pasta com material bibliográfico sobre coleta seletiva de revistas e jornais, diversos objetos e brinquedos produzidos com material reciclado, jogo, diversos tipos de lixo, modelos de animais plásticos relacionados ao lixo, modelos dos recipientes oficiais nas cores padronizadas para o recolhimento de recicláveis. Este kit, conforme nossas observações, é totalmente diferente do anunciado no site do zoológico. 
- Modelos de animais: baratas, ratos, cobra, aranha, escorpião.

- Outros: folheto com atividades e informações sobre lixo e reciclagem, calendário de papel reciclado, folheto sobre fabricação de tapetes de carro com pneus reciclados, mini tapete de carro produzido com pneu reciclado, sacola com materiais de escritório reciclados, jogo, palhacinho feito de material reciclado, bloco de papel reciclado, chapa de garrafa PET utilizada no Zoológico, modelos de embalagens usadas para depósito de lixo reciclável, manual para o professor.

Figura 25: Objetos constituintes do kit Lixo II Fotos de Márcia Fernandes Lourenço

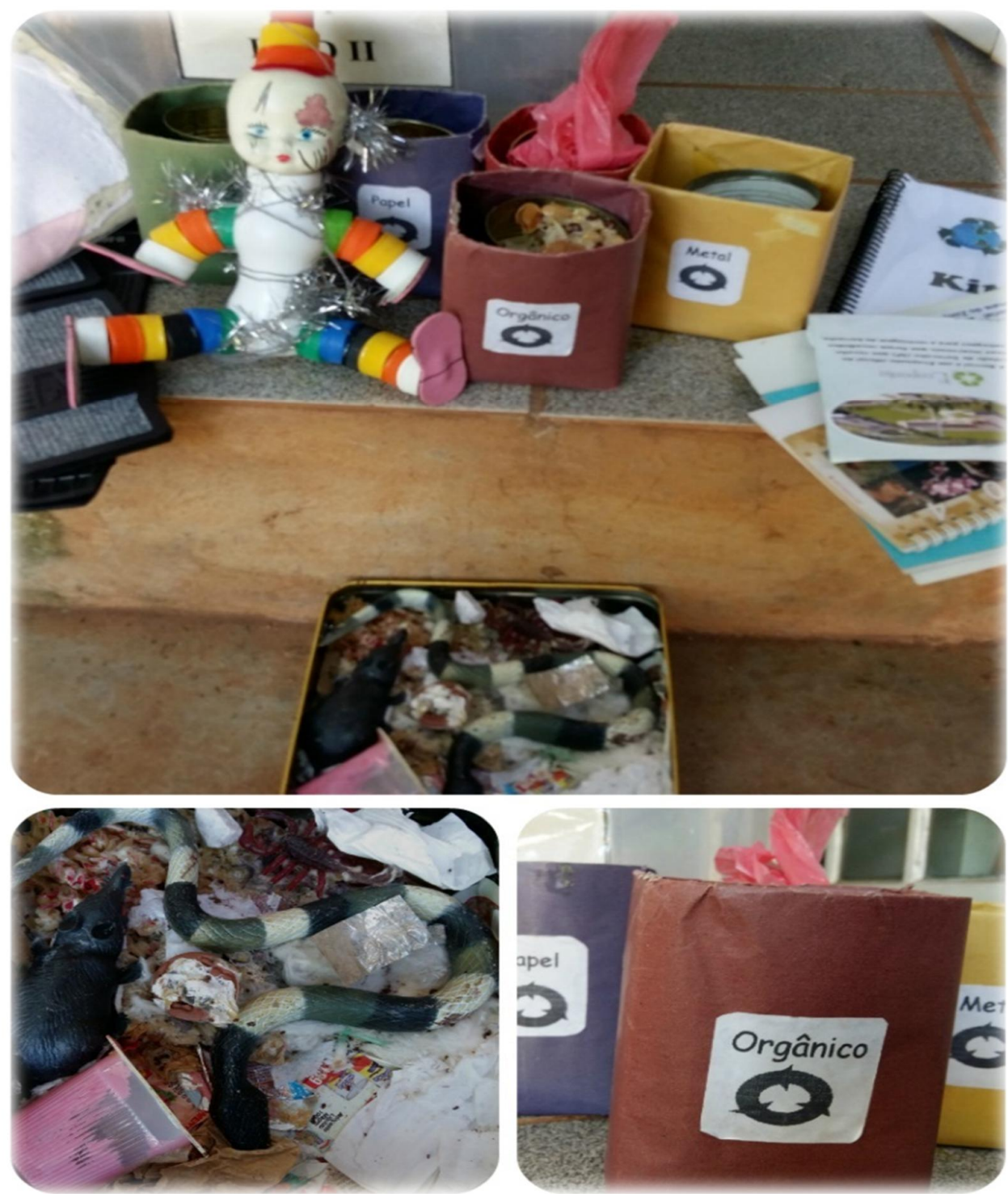




\section{Ecologia}

24. Botânica I - interação animal-planta (Figura 26): No interior da caixa estão uma pasta com exsicatas de plantas, 2 caixas plásticas menores com a coleção de frutos e sementes, fotos, manual para o professor, uma caixa pequena com uma lupa manual e pinça. As sementes encontram-se no interior de pequenos frascos plásticos e identificados com nome popular e científico. Os animais em via seca estão soltos dentro da caixa.

- Exsicatas: 25 espécies de plantas secas com identificação e descrição, coleção de frutos e sementes (amor-de-moça, ave-do-paraíso, Bauhinia, Calliandra, Callistemo, copaíba, coroade-cristo, embaúba, flamboyant, flor-de-papagaio, flor-de-são-joão, goiaba, grevilã-anã, hibisco, ixora, juá, lantana, malvavisco, melão-de-são-caetano, espirradeira, primavera, russélia, sálvia, sanquésia, sapatinho-de-judia).

- Partes de animais em via seca: cabeça de arara, tucano e papagaio, crânio de tucano.

- Sementes: mulungu, palmito jussara, araçá-roxo, araticum, castanha-do-maranhão, aroeira-pimenteira, angico, girassol, palmeira.

- Outros: manual para o professor, uma lupa manual e 1 pinça, coleção de fotos de animais e plantas.

- Frutos e sementes: bromélia, coco-da-baía, copaíba, jerivá, paineira, palmeira-rabode-peixe, pinheiro, soboeiro.

- Ninho: 1 ninho de ave não identificado. 
Figura 26: Objetos constituintes do kit Botânica I - interação animal-planta Fotos de Márcia Fernandes Lourenço

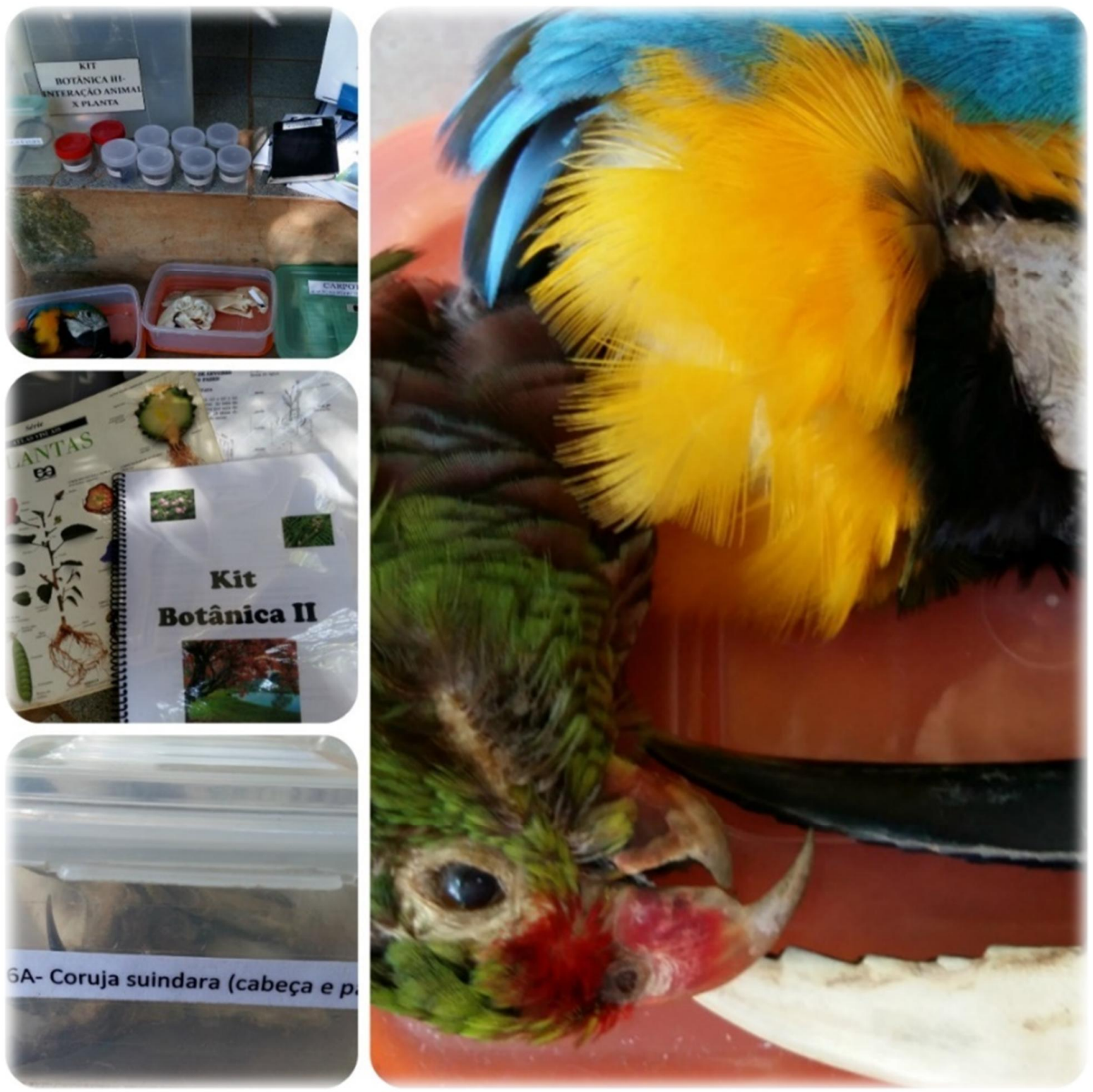

\section{Etnias indígenas}

25. Índio I (Figura 27): No interior da caixa há uma pasta contendo o manual para o professor, cartões, folders e livros. Existem também 25 objetos de origem indígena identificados e nãoidentificados. Não há descrição dos materiais do kit no site do zoológico. Conforme nossas observações, o kit é composto pelas seguintes materiais: 
- Apetrechos indígenas: pá para virar beiju, escultura de onça, cigarro indígena, cabaça, peixe de madeira, cesto de pesca, cintos, brincos, tornozeleiras, tá, cestos diversos, panela de barro, abanadores, chocalho de tornozelo, cocares, chocalho de casco de tartaruga, esteira, flautas, pedaço de cipó, cano com 3 armas

- Outros: manual para o professor, livros sobre cultura e arte indígena, folder e cartões postais com pinturas indígenas.

Figura 27: Objetos constituintes do kit índios I

Fotos de Márcia Fernandes Lourenço
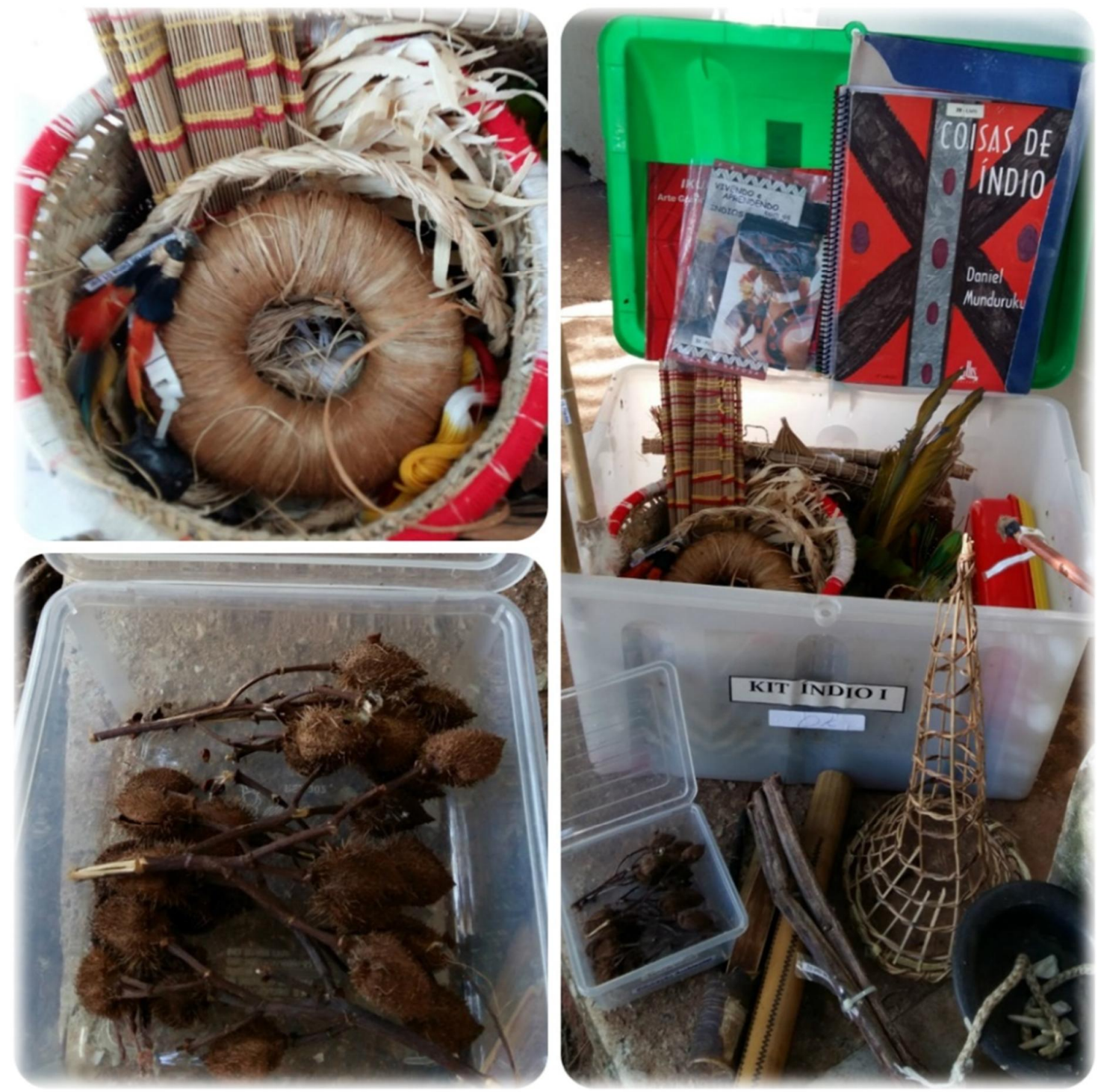
26. Índio II (Figura 28): No interior da caixa há uma pasta contendo o manual para o professor, cartões e uma apostila. Existem 15 objetos de origem indígena identificados e não-identificados. Não existe este kit no site do zoológico. Conforme nossas observações, o kit é composto pelos seguintes materiais:

- Apetrechos indígenas: zarabatana, dardos, boneca de palha, flauta, peão, peteca de palha, brinquedo não identificado, cuia, cinto, bracelete de dente, chocalho, cesta e rede.

- Outros: manual para o professor, cartões com pintura corpórea do Kuikuros, livro para colorir sobre brinquedos indígenas da Amazônia, apostila "Projeto vivendo e aprendendo com os índios".

Figura 28: Objetos constituintes do kit índios II Fotos de Márcia Fernandes Lourenço
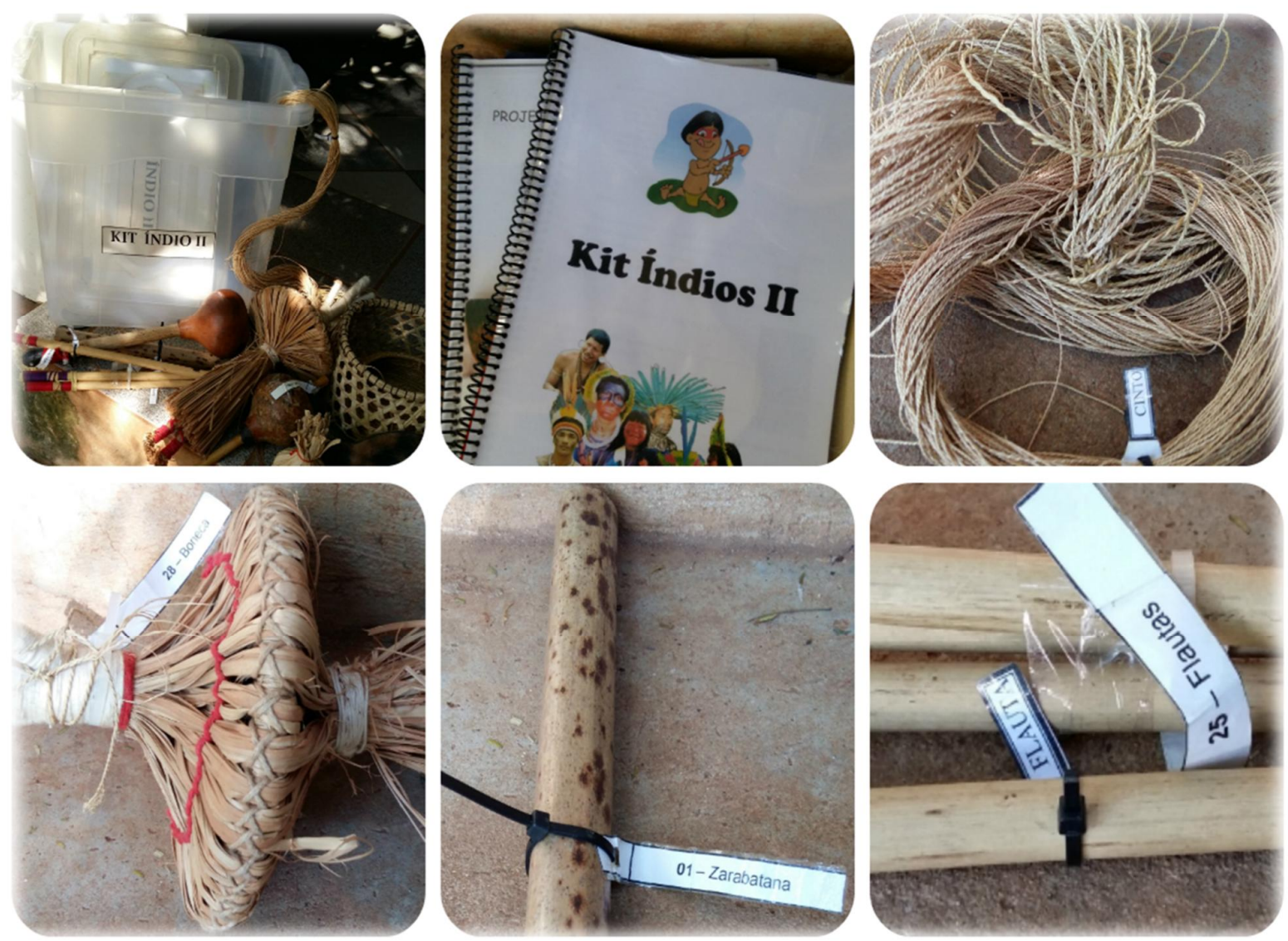
Ainda sobre as finalidades dos kits, Belinassi e Mergulhão (2006) apontam com base em avaliação feita junto a professores e alunos que os utilizaram em sala de aula, a importância deste material para que se atinja uma aprendizagem diversificada para pessoas que necessitam ver e envolver-se fisicamente para aprender. Segundo as autoras, os kits transformam as aulas em experiências multissensoriais despertando a curiosidade dos alunos para uma eventual visita ao zoológico. O fator “despertar curiosidade" é, na visão das autoras, de extrema importância, pois para elas não se pode ensinar nem aprender sem curiosidade. A motivação despertada pelos materiais pode, para elas, induzir à busca e ao questionamento da realidade que abre portas para um processo educativo muito rico com o contato com diferentes elementos, fenômenos e acontecimentos propiciando a ampliação das experiências e construção de conhecimentos diversificados. Ainda segundo as autoras, é imprescindível atender à demanda dos professores por materiais de qualidade e que forneçam subsídios teóricos às aulas. $\mathrm{Na}$ concepção das mesmas, o dia-a-dia na sala de aula pode se tornar mais rico se mesclado com atividades que tornem a aula mais dinâmica e estimulante contribuindo para o aprendizado de conceitos e conscientização sobre a problemática ambiental.

As autoras ainda descrevem os manuais para o professor em relação às suas características e aos objetivos que tiveram no momento da criação e afirmam que

"Os manuais possuem muitas curiosidade e dicas que facilitam o desenvolvimento do tema abordado, de maneira que o professor possa estimular a curiosidade e prender a atenção dos alunos" (BELINASSI; MERGULHÃO, 2006, p. 304).

Pudemos também encontrar menção ao manual para o professor em alguns trechos do Relatório Anual de 1997 que aponta que os manuais foram feitos para orientar o professor e sugerir atividades com os kits (RELATÓRIO ANUAL, 1997). A entrevistada 3, por exemplo, afirma que o guia foi feito para o que o professor tivesse condições de se utilizar do kit priorizando o máximo de informações sobre os objetos presentes nele.

Segundo nossas observações, os manuais para o professor somente citam o nome do Zôo de Sorocaba como autor do material, mas não contextualizam nem trazem informações sobre a instituição. Outra informação presente nos manuais são as "Dicas de como usar o kit" que indicam os cuidados e a organização do material. 
Os guias são bastante ricos em informações conceituais sobre o tema tratado, o que pode auxiliar o professor a produzir aulas mais ricas e potencializar discussões sobre conceitos biológicos. O material também pode proporcionar discussões sobre questões polêmicas como causa da extinção de animais e plantas quando apresenta lista de animais ameaçados, como pudemos identificar em várias falas da entrevistada 3.

Nas entrevistas observamos que a questão conceitual, de manipulação para despertar a curiosidade e motivar o público a que se destina estiveram muito presentes durante a confecção dos materiais, como podemos constatar em diversas falas da entrevistada 3 que afirma que os kits foram elaborados com a intenção de manipulação pelo público para que este observe as características e o comportamento que eventualmente tenha relação com a morfologia. Para ela, os materiais envolvem o público na temática de que trata.

Ainda nas entrevistas percebe-se que o assunto de temas relacionados à problemas sociais foram considerados na produção dos kits, principalmente a questão ambiental. Podemos observar que em alguns dos trechos das entrevistas esta questão aparece, como por exemplo, na entrevistada 2 quando ela afirma que os kits apresentam temas com problemática sociológica e de saúde, como nos kits de índios e lixo. A entrevistada 3 afirma que uma das intenções para a criação deste material era discutir a questão da ameaça ao lobo-guará na região de Sorocaba, a ideia era discutir a ameaça de extinção no contexto da cidade e do cotidiano das pessoas e tentar fazê-las refletir sobre os fatores e as reponsabilidades sobre esse tema.

Os Relatórios Anuais igualmente nos indicam a ênfase grande na questão conceitual e motivacional como objetivos da produção do material fazendo com que os professores tornassem suas aulas mais interessantes e interativas utilizando-se de materiais biológicos originais e moldes que pudessem ser manipulados. Abaixo um exemplo de um trecho do relatório de 2003:

"O acervo para empréstimo dá subsídios para os educadores trabalharem os diferentes assuntos fora do zôo tornando-se agentes multiplicadores das atividades do zoológico" (RELATÓRIO ANUAL, 2003)

Tanto as mochilas quanto os kits possuem forte ênfase em seus objetivos nas questões conceituais com relação a morfologia e comportamento dos animais. Além disso, reforçam a importância da conservação tanto por meio dos objetos escolhidos para compor os materiais quanto pelo discurso esperado do mediador (no caso da mochila), assim como nas orientações 
dos manuais para uso dos kits pelos professores. As questões mais relacionadas a impactos sociais na relação com o ambiente aparecem em menor intensidade nos kits, estando ausentes nas intenções e objetivos do uso da mochila nas visitas.

\subsubsection{Análise qualitativa e quantitativa dos materiais educativos na perspectiva da} $\mathrm{AC}$

No segmento abaixo, apresentaremos a análise qualitativa e quantitativa com base nas observações realizadas sobre os materiais educativos, mas também nos dados oriundos das entrevistas e dos documentos. A intenção foi caracterizar, com base nessas informações, os indicadores e atributos de AC que se expressam nesses materiais.

Para realizar a análise elaborou-se uma tabela (Quadro 1) com as descrições e caracterizações de cada material e, em seguida, classificamos os indicadores e atributos de AC identificados a partir dos dados coletados. A tabela com as informações completas encontra-se no Apêndice E.

Foram observados $27(\mathrm{~N}=27)$ materiais educativos (26 kits ecológicos e 1 mochila de curiosidades) utilizados pelos visitantes no Zôo e pelos professores das redes pública e privada.

Apresentamos a seguir a análise dos indicadores e atributos de AC identificados nos materiais, apresentando exemplos dos dados que nos levaram a categorização realizada e caracterizando como cada um deles se expressa qualitativamente e quantitativamente nos materiais. Neste momento ainda buscamos expressar numericamente as ocorrências de cada indicador e atributo para que fosse possível perceber de forma mais evidente como o processo de AC aparece nas intenções que fundamentam os materiais educativos produzidos e na sua concretização.

Lembramos que a unidade de análise foi o material em si, como indicado na metodologia desta pesquisa, assim, quando um indicador e seu atributo estavam presente apontamos na última coluna da tabela.

\section{A - INDICADORES E ATRIBUTOS DE AC NOS MATERIAIS EDUCATIVOS}

Abaixo apresentamos nossa análise da presença dos indicadores e atributos de alfabetização científica nos materiais educativos.

\section{1 - Indicador Científico}


Este indicador foi identificado nos 27 materiais observados (Figura 29). É nesse indicador que se encontram os atributos relacionados a aspectos inerentes à ciência, como processos e produtos do conhecimento científico, a apresentação de seus termos, conceitos, teorias e ideias e seus significados, além das concepções de ciência que fundamentam a compreensão sobre seu processo de produção.

Pudemos verificar nas entrevistas, que os idealizadores dos materiais tiveram grande preocupação em fornecer informações biológicas sobre os animais do Zôo. As entrevistas realizadas e os documentos analisados corroboram com os dados encontrados nas nossas observações, revelando como este indicador aparece nas intenções e na produção do material educativo do Zôo. O relatório anual 2001/2002 nos apontou essa questão dizendo que quando os materiais foram concebidos eles tinham como objetivo auxiliar nos conhecimentos das características morfológicas e adaptativas dos animais e fazer com que o público os relacione com o ambiente em que vivem (RELATÓRIO ANUAL, 2001/2002). A entrevistada 3 também indica isto na sua fala em várias ocasiões, como podemos observar abaixo:

“...se você vai falar de dentição, de um osso pneumático, de dispersão de semente, interação, deve oferecer o máximo de recursos que você tiver para ilustrar seu discurso..." "...procuramos tudo o que tínhamos disponível, quando não tínhamos condições de ter o objeto, nós ilustrávamos com fotos para esclarecer melhor o conceito" (RELATÓRIO ANUAL, 2001/2002)

Portanto, a presença deste indicador nos materiais revela que a dimensão conceitual/científica da $\mathrm{AC}$ é central e pode ser trabalhada pelo público que os utiliza.

\section{Atributo 1a-Conhecimentos e conceitos científicos e suas definições}

Este atributo refere-se aos conceitos, leis, teorias e ideias científicas gerais legitimadas pela ciência sobre os temas abordados.

Identificamos sua ocorrência nos 27 materiais analisados (Figura 30). A presença deste atributo em todos os materiais estudados se dá pelo fato de que o objetivo da produção dos materiais era de ensinar conceitos de Biologia, como por exemplo, características morfológicas e adaptativas dos animais, interação animal-planta, conservação, interação homem-ambiente, conceitos de ecologia, relacionar o alimento com o animal observado, como destaca a entrevistada 3 dizendo 
que o material proporciona conhecimento científicos criando discussões conceituais a respeito das temáticas a que se propõem.

Os manuais para o professor trazem principalmente conteúdo biológico sobre os objetos do tipo definição de grupos zoológicos, importância ecológica dos ambientes, morfologia externa de animais, características de animais e plantas, importância da água, diversidade animal e vegetal, classificação biológica, adaptações dos animais ao modo de vida e ao ambiente. Além dos manuais, outras publicações presentes nos kits priorizam as informações biológicas dos organismos. Grande parte dos itens dos kits são organismos ou partes deles conservados, modelos e moldes de animais ou vegetais, o que leva a uma tendência de relacionar com conceitos científicos tratados em aulas de Ciências ou Biologia, essas informações são carregadas de elementos da ciência, como conceitos e nomes científicos. Podemos confirmar isto no Relatório Anual de 2001/2002 que discute a intenção desses materiais:

“... auxiliar no conhecimento das características morfológicas e adaptativas dos animais e seus ambientes, dados biológicos e curiosidades dos animais, pois muitos dos animais e suas partes (bico, crânio, patas, cascos etc.) jamais poderiam ser observados e tocados com tantos detalhes" (RELATÓRIO ANUAL 2001/2002)

\section{Atributo $1 b$ - Pesquisas científicas}

Não encontrado.

\section{Atributo 1c - Processo de produção de conhecimento científico}

Está relacionado com os métodos e procedimentos da ciência: como a formulação de hipóteses, realização de testes, registros, observação, criatividade, publicações científicas/acadêmicas, discussão sobre método científico, a divulgação científica ou educação como parte do processo de produção do conhecimento.

Este atributo aparece somente $1 \mathrm{vez}$, no kit Artrópodes. O material bibliográfico do kit apresenta alguns processos de preparação dos materiais, de coleta e de pesquisa sobre animais perigosos ao ser humano. A entrevistada 2 menciona que eventualmente o professor pode explicar como é o processo de coleta, preparação e conservação dos animais. 
Atributo 1d - Papel do pesquisador no processo de produção do conhecimento

Não encontrado

Atributo le - Dinâmica interna da Ciência

Não encontrado.

\section{2 - Indicador Interface Social}

O indicador "Interface social" também aparece em todos os materiais. Esse indicador ressalta a dimensão da interface entre ciência, tecnologia, inovação e a sociedade, expressando aspectos da influência e impactos da Ciência na sociedade e da influência e participação da sociedade nela. Este indicador considera também a importância de outras formas de conhecimento e saberes. Este indicador incorpora a opinião e a efetiva participação da sociedade, tanto na origem e desenvolvimentos das pesquisas, como diante de seus resultados.

Nossa hipótese é que os materiais apresentam temas que despertam a discussão de questões polêmicas ou sócio científicas que fazem parte do cotidiano do cidadão, como poluição, perda de ambientes naturais, conservação da biodiversidade, utilização de animais no cotidiano, doenças causadas por animais, relação do ser humano com animais, animais perigosos, entre outros.

As entrevistadas 2 e 3 mencionaram que durante a concepção dos materiais foi pensado introduzir este tipo de discussão com o público. Elas afirmaram que o crânio da onça com a marca de um tiro, o vidro de palmito estragado e o cano de transporte de pássaros, por exemplo, podem estimular discussões polêmicas sobre caça ilegal, tráfico de animal, retirada e venda de palmito ilegal fazendo com que questionamentos e reflexões surjam e, inclusive, segundo a entrevistada 3, essas discussões podem levar ao questionamento da postura desse público em relação a esses temas.

\section{Atributo 2 a - Impactos da ciência na sociedade}

Este atributo está relacionado com os aspectos positivos ou negativos, riscos e benefícios do desenvolvimento da ciência, incluindo as controvérsias sobre sua relação com a sociedade, as questões éticas envolvidas na relação da ciência com sociedade e também a conexão com o cotidiano e a resolução de problemas dos cidadãos. Além disso, como a ciência pode influenciar nas questões históricas, políticas, econômicas, culturais e ambientais da sociedade. 
Este atributo está presente em 11 dos 27 materiais estudados como apresentado abaixo:

- Mamíferos I e II, Répteis I e II - discutindo a questão da destruição dos ambientes e as espécies de animais desses grupos ameaçados de extinção e propõe uma reflexão sobre o papel do ser humano neste processo. Discute também a invasão de alguma desses animais perigosos às casas nas cidades;

- Animais Peçonhentos e Artrópodes - traz a relação do ser humana com aranhas e escorpiões e a relação da limpeza, conservação do entorno para a prevenção de acidentes;

- Parasitose Humana - discute a questão da relação das parasitoses com o saneamento básico e sua prevenção;

- Interação animal-planta - o manual para o professor coloca a importância da polinização para a produção de alimentos e discute a questão do uso indiscriminado de defensivos;

- Lixo I e II -apresenta diversos materiais que discutem a destinação do lixo, animais que vivem no lixo, alternativas para o lixo, coleta seletiva, lixo e qualidade de vida, reciclagem e consumo responsável.

- Mochila - este material não apresenta manual para professor e nem material bibliográfico de qualquer tipo. No entanto, os objetos têm o potencial de discutir, tráfico de aves, caça ilegal, importância do anilhamento, destruição de ambientes, consumo responsável e conservação.

Percebemos que tanto o conteúdo dos manuais para o professor quanto os itens do kit têm potencial de despertar discussões sobre aspectos positivos ou negativos, riscos e benefícios do desenvolvimento da ciência, a conexão com o cotidiano do cidadão e a resolução de problemas da vida diária através de informações fornecidas pela ciência, como a sociedade lida com as controvérsias inerentes da ciência e como a produção da ciência pode influenciar aspectos sociais e principalmente ambientais. As entrevistadas 2 e 3 referem-se aos materiais como disparadores de discussões relacionadas à caça ilegal, tráfico de animais e às escolhas no cotidiano, como podemos constatar nas falas a seguir das entrevistadas 2 e 3 respectivamente, “... (o cano de transporte) cria uma discussão sobre caça ilegal e tráfico de animais" e "O vidro de palmito desperta discussão polêmica...minha mãe compra palmito, minha mãe não compra. Era o que a gente esperava e percebia”. O material integra ideias científicas com conservação ambiental, ligando essas ideias a dois temas reconhecidos como fundamentais para a manutenção da sociedade e do planeta: a conservação do ambiente e da biodiversidade.

Os documentos examinados também trazem aspectos relacionados a este atributo, como por exemplo nos Relatórios Anuais de 1993 a 1996 temos a afirmação de que 
"Aumentar a consciência ecológica na relação do homem com seu ambiente tem como objetivo tornar as pessoas mais conscientes de suas responsabilidades com relação ao meio ambiente e auxiliá-las nas escolhas que fazem em relação aos produtos que consomem" (RELATÓRIO ANUAL, 1993-1996).

\section{Atributo $2 b$ - Influência da economia e politica na ciência}

Este atributo tem relação com os fatores políticos, econômicos e comerciais que influenciam as pesquisas científicas, ao financiamento da ciência e à propriedade intelectual, patentes e transferência de tecnologia.

Este atributo foi identificado em 3 materiais: Interação animal-planta, Mamíferos I e II. Neste caso também o conteúdo e os objetos podem, potencialmente, estimular discussões sobre fatores políticos e econômicos que influenciam as pesquisas científicas, pois a temática dos materiais está diretamente relacionada com a vida humana, interesses comerciais em relação à destruição de ambiente e ameaça de extinção de animais, principalmente mamíferos e utilização de defensivos agrícolas matando polinizadores que diminuiriam a produção de alimentos. As entrevistadas tinham como objetivo discutir essas questões quando conceberam os materiais, elas citam em várias ocasiões que a intenção deles era discutir questões de políticas públicas e como cada um poderia contribuir individualmente e coletivamente.

Atributo 2c - Influência e Participação da sociedade diante da ciência

Refere-se a origem e ao desenvolvimento da pesquisa a partir de demandas da sociedade, sua opinião sobre a ciência, seus processos, produtos e resultados. Está também relacionado à efetiva participação da sociedade nas decisões sobre ciência e a utilização dos resultados para tomada de decisões, além dos impactos da ação da sociedade na pesquisa científica (principalmente quando se trata de meio ambiente).

Identificamos 8 materiais educativos com a presença deste atributo - Praia Arenosa (poluição e animais comestíveis); Animais Peçonhentos (conhecimento sobre a toxicidade deles); Parasitose Humana (saneamento básico e prevenção de doenças); Lixo I e II (saneamento básico, destinação do lixo, doenças, reciclagem); Índio I e II (preconceito, questões de demarcação de terra, aculturação); Mochila de curiosidades (tráfico de animais, caça ilegal, consumo responsável). 
Este atributo está diretamente relacionado à participação da sociedade nas decisões sobre temas que se julguem importantes serem pesquisados ou que estejam relacionados à vida das pessoas. Por exemplo, quando se discutem as parasitoses que afetam o ser humano, isto possibilita o empoderamento do cidadão que tem acesso à informação e consequentemente a cobrança de melhorias sanitárias por parte das autoridades. O mesmo pode se dar quando se discute lixo e poluição do mar. Na discussão sobre animais peçonhentos, as informações ecológicas sobre esses animais podem contribuir tanto para a diminuição de acidentes quanto para a conservação dessas espécies. O material possibilita a reflexão sobre a importância de um posicionamento dos indivíduos sobre conservação e a manutenção dos recursos naturais, além de outras numerosas possibilidades de reflexão.

As entrevistas nos trazem algumas considerações sobre estes pontos, como por exemplo na questão da interação dos estudantes com o cano de transporte de animais traficados, a entrevistada 3 nos conta que as crianças se interessam muito pelo assunto, discutem como é feito o tráfico, quantos animais cabem no cano, quem fiscaliza. A discussão sobre a questão de saúde também vem à tona, segundo a entrevistada 2, quando o vidro de palmito é retirado da mochila e apresentado aos alunos, eles se colocam sobre como é na casa deles, se compram ou não palmito ilegal etc.

\section{Atributo $2 d$ - Identificação dos tipos de público}

Este atributo refere-se ao público ao qual se destina o material: comunidade científica ou público especializado, ao público escolar, a comunidades ou grupos específicos.

Este atributo foi identificado em 23 materiais quando citam a ocasião de sua utilização. As entrevistas e os documentos mencionam em diversas oportunidades que o objetivo da criação dos kits ecológicos foi de ajudar os professores nas aulas de Ciências e Biologia e que esses materiais são utilizados em sala de aula pelos professores. Apesar das entrevistas deixarem claro que os materiais são utilizados prioritariamente pelo público escolar, a entrevistada 3 também nos contou que eventualmente os educadores do Zôo de Sorocaba podem utilizá-los para atividades no próprio local.

Um dos Relatórios Anuais (2001/2002) menciona que os materiais educativos do Zôo são essenciais para o ensino de qualquer conteúdo de Biologia e Ciências pois permite a manipulação e a interação que podem proporcionar um aprendizado significativo e prazeroso (RELATÓRIO, 2001/2002). 
Atributo $2 e$ - Ações e produtos de divulgação científica, educação formal e não formal

Este atributo tem relação com as ações ou produtos veiculados pela mídia e redes sociais, produções de livros, filmes, peças teatrais, exposições, publicações científicas, ações de ensino de ciências no contexto escolar e fora dele, formação de públicos específicos como professores e educadores, entre outros.

Identificamos a ocorrências deste atributo nos 27 materiais examinados. Como constatado nas entrevistas e nos documentos, os materiais foram concebidos para público escolar, portanto ações de ensino de ciências no contexto escolar e ações de formação de públicos específicos como professores e educadores estão explicitadas em vários momentos tanto do conteúdo, como dos itens dos kits e nas orientações de utilização. A entrevistada 3 afirma que os guias dos kits são uma orientação para o professor e que no momento da confecção, elas tentaram colocar o máximo de informação para que o professor tivesse subsídios para as aulas. Isto também é corroborado pelo Relatório Anual de 2009, vol. II que nos informa que um dos objetivos dos materiais era disponibilizar informações sobre animais e seus ambientes para facilitar as aulas.

A publicação de Belinassi e Mergulhão (2006) que tratou dos kits ecológicos nos indica a ênfase grande nos materiais como subsídios para aulas, como vemos na citação abaixo:

“...a biblioteca também coloca à disposição da população um precioso acervo didático cujas peças podem ser emprestadas por um período limitado, sendo assim muito procurado por professores que buscam subsídio para enriquecer suas aulas" (BELLINASSI; MERGULHÃO, 2006, p. 301)

\section{Indicador Institucional}

O "Indicador Institucional" apareceu em 25 materiais investigados. Este indicador expressa a dimensão das instituições envolvidas com a produção e o fomento da ciência e sua função social. Quando presente nos materiais produzidos, permite identificar, por exemplo, a missão institucional relacionada ao ensino, pesquisa e extensão, à formação de recursos humanos e às ações de divulgação e educação científica que realizam.

Durante as entrevistas pudemos constatar que as idealizadoras não tinham o objetivo de discutir, por meio dos materiais, como a instituição estava relacionada à produção da ciência dentro de seus muros. Apesar do Zôo de Sorocaba ser uma referência nacional em termos de manejo e 
educação ambiental (GARCIA, 2006) e possuir um Museu de Zoologia com uma coleção de animais, os manuais para o professor nunca tocaram nestes aspectos. A entrevistada 3 deixou claro que a intenção deles era ensinar conceitos e motivar os alunos a discutirem questões de conservação. Nesse sentido, não houve menção à instituição nos documentos analisados em relação aos materiais educativos. Contudo, na maioria dos materiais encontramos a identificação da instituição que os produziram, sendo este o único atributo percebido neste indicador.

Atributo $3 a$ - Identificação das instituições envolvidas na produção e fomento à ciência

Este atributo tem relação com a identificação das instituições executoras dos projetos, órgãos governamentais e/ou privados envolvidos, os órgãos governamentais e privados de fomento, etc.

Registramos a presença deste atributo em 25 materiais. Este atributo esteve presente na forma da autoria dos manuais para professor e na citação de autoria de materiais bibliográficos de outras instituições. Nos materiais onde não apareceu (Água doce/rios, Anfíbios e Animais Peçonhentos), não havia manual para o professor ou nada indicava a autoria dele. As entrevistas e documentos não mencionam este tópico. Se o público identificasse que os materiais foram idealizados e produzidos pelo Zôo, talvez pudesse relacionar que está visitando uma instituição de pesquisa que produz conhecimento.

Atributo $3 b$ - Identificação da missão institucional

Não encontrado

Atributo 3c Presença de elementos políticos, culturais e sociais ligados à instituição

Não encontrado

\section{Indicador Estético/Afetivo/Cognitivo}

O indicador estético/afetivo/cognitivo está presente quando a ação de divulgação científica tem potencial para despertar dimensões relacionadas à afetividade, interação, percepção, motivação e aprendizagem. Quando presente nas ações de divulgação científica, é possível reconhecer a intenção e o potencial para sensibilizar o público e envolvê-lo de diversas maneiras, possibilitando a aprendizagem por meio de diferentes formas interações. Quando aplicado para 
análise do público, se revela a partir das manifestações de sentimento e por meio de expressões e ações dos sujeitos que revelem operações epistêmicas e habilidades investigativas.

Nossas observações apontam que este indicador apareceu em todos os materiais analisados. A alta incidência deste indicador, a nosso ver, está ligada aos objetivos da produção dos materiais, expresso nos documentos e nas entrevistas. $\mathrm{O}$ contato e a interação são importantes para estimular os estudantes na discussão e na relação com o conhecimento e este é um ponto importante para a promoção da AC. Os materiais foram pensados e produzidos com o objetivo de despertar sentimentos, afetividade, estimular o diálogo, a interação física e sensorial e a motivação nos estudantes que entraram em contato com eles, conforme afirmação das entrevistadas 2 e 3 e Relatórios Anuais. Podemos observar em alguns trechos das entrevistas tal preocupação no momento da concepção e produção dos mesmos, como nos mostraram as entrevistadas 2 e 3 que afirmam que a produção das mochilas surgiu do fato de uma delas ser educadora e ter a preocupação de tornar as visitas mais concretas, interativas e interessantes. Além disso, para elas, os materiais despertam a curiosidade das crianças porque elas podem manuseá-los, conhecer as características dos animais tendo contato direto com eles. A afirmação da entrevistada 3 deixa bem claro esta questão “... os materiais são importantes para que as crianças tenham um momento de vivenciar, de ter uma experiência única, de viver aquele momento único, de poder ter o contato".

O mesmo podemos encontrar no Relatório Anual de 2009, vol. II, na pesquisa realizada com professores que participaram da atividade com a mochila:

A pesquisa foi realizada com 16 professores que participaram da visita com a utilização da mochila. Foram feitas perguntas aos professores sobre os materiais da mochila, dentre elas estão: "Qual a parte da visita que mais chamou a atenção?" e "Quanto ao conteúdo abordado: Por quê?". Dos pesquisados, seis (6) deles apontaram que a parte que chamou mais atenção na visita "foi o contato com os objetos biológicos preservados" presentes nas mochilas. Com relação à segunda questão foram identificadas as seguintes afirmações: "Fundamental para a imaginação dos alunos"; "Despertou o interesse dos alunos" (RELATÓRIO ANUAL, 2009, VOL II).

A presença significativamente alta deste indicador, nos parece um fato que incita nos visitantes a compreensão dos temas científicos expostos, abrindo possibilidades para discussões de questões relacionadas à conservação da biodiversidade, que são dimensões importantes da AC. 
Importante destacar que como os demais atributos dos outros indicadores, os atributos $4 \mathrm{a}, 4 \mathrm{~b}$ e 4c estão ligados pois os materiais que proporcionam interação entre os pares, contemplação, discussões e reflexões, naturalmente também levam a uma maior conexão com a vida pessoal e experiências anteriores, como veremos a seguir.

\section{Atributos 4a-Estético e Afetivo}

Este atributo refere-se a uma ação ou produto que apresenta, em suas estratégias, potencial para estimular manifestações de sentimentos como apreço, prazer, repulsa, indignação ou outras sensações, tanto em relação a ciência quanto a formato como ela está sendo apresentada. Além disso, possibilita momentos de contemplação e de apreciação estética e artística, oportunizando a expressão de experiências pessoais.

Este atributo também aparece nos 27 materiais. Os dados confirmam o que as entrevistas e os documentos mostraram: os materiais foram feitos para despertar a atenção, curiosidade e ser um estímulo para o aluno que entra em contato com ele, o recurso utilizado estimula a percepção, a contemplação e a exploração dos sentidos como um fator de envolvimento do público com a temática.

Podemos notar em trechos selecionados das entrevistas, que as idealizadoras dos materiais afirmam que alguns alunos tocam e ficam curiosos, mas eventualmente manifestam estranheza, geralmente em relação a partes dos animais, que segundo elas, pode causar repulsa. A entrevistada 3 mencionou que talvez essa estranheza, seja consequência da falta de hábito ou de proximidade com o material biológico, no entanto, segunda ela, eles querem chegar perto, pegar e manipular os objetos.

A entrevistada 3 ainda fez a seguinte reflexão:

\footnotetext{
“Apreço, prazer, repulsa, indignação, medo, nojo, admiração são sensações que certamente são despertadas quando as pessoas entram em contato com materiais originais. Todas essas sensações possibilitam aproximar-se e desencadear diálogos sobre o conceito que se quer compartilhar".
}

Ambas as entrevistadas afirmaram que existia a intenção de que o visitante realizasse uma apreciação não somente cognitiva, mas também afetiva no contato com os materiais. Portanto, segundo nossos dados e as entrevistas, podemos afirmar que os materiais educativos podem estimular a percepção, a contemplação e a exploração dos sentidos sendo um fator de envolvimento do público com o conceito tratado. 


\section{Atributo $4 b$ - Cognitivo}

Identificamos este atributo nos 27 materiais examinados e é percebido quando o material educativo promove habilidades relacionadas aos processos de investigação científica e operações como observação, nomeação, afirmação, comparação, caracterização, suposição, explicação, questionamento, emissão de opinião, conclusão e generalização, a partir da interação com o objeto. Como afirmou a entrevistada 3 “....a partir da interação com os objetos o visitante perguntava, comentava com o colega, trazia conexões de sua vida, escola e relacionava com aquele momento".

A natureza dos materiais também estimula operações de maior elaboração conceitual realizadas a partir da interação concreta com o objeto: levantamento de hipóteses, explicações e generalizações. Como mencionou a entrevistada 2, é possível perceber a concentração e a atenção que os alunos manifestavam durante a interação com os objetos sendo que depois disso estabelecem relações entre características morfológicas e modo de vida.

O Relatório Anual, 2001, 2002 também menciona o fato de que o contato com os objetos dos kits proporciona um aprofundamento de conhecimentos sobre morfologia e faz com que os alunos os relacione com seus ambientes. O relatório afirma que a aproximação e a interação física com a diversidade de objetos dos materiais levam os alunos a comparação dos animais entre si e a construção de conclusões a respeito do modo de vida de cada animal (RELATÓRIO ANUAL, 2001/2002).

\section{Atributo $4 c$ - Interação física e sensorial}

Esse atributo considera os diversos níveis de interatividade física e sensorial com o produto ou objeto e se a ação de divulgação científica possibilita e estimula uma relação entre os diversos atores envolvidos, identificando, também se há valorização dos conhecimentos prévios do público.

Este atributo foi identificado em todos os materiais analisados. Estes materiais propiciam diversos níveis de interatividade com o conhecimento, incentivam o diálogo entre os estudantes e os professores, estimulam a contemplação e a reflexão sobre questões diversas, valorizam os conhecimentos prévios e saberes diversos, bem como a manifestação dos estudantes a respeito de conceitos pré-existentes. Todas essas ações podem desencadear questionamentos e impressões sobre os temas abordados. A presença deste atributo é um dado positivo para o 
processo de $\mathrm{AC}$, uma vez que a interatividade, sentimentos de admiração pelo mundo natural e a motivação são fatores essenciais para o engajamento do público com o tema exposto.

A entrevistada 3 afirma que a produção da mochila de curiosidade surgiu devido à sua preocupação em tornar as visitas mais acessíveis, interativas e possibilitar a reflexão, por parte das crianças, de assuntos como conservação e extinção. A entrevistada menciona que o fato das crianças terem um momento de interação física e discussão sobre esses assuntos faz com que seus conceitos pré-existentes sobre diversos assuntos sejam repensados ou resignificados. $\mathrm{O}$ Relatório Anual de 2003 também afirma que a produção dos materiais enriqueceu muito a metodologia utilizada em várias atividades do Zôo de Sorocaba proporcionando momentos de motivação, interesse, por parte do público, pelos assuntos tratados na instituição devido à proximidade dos animais ou partes deles, proporcionadas pelo uso dos materiais (RELATÓRIO ANUAL, 2003).

Como síntese da análise dos materiais, assinalamos a ocorrência dos Indicadores Científico, Interface Social e Estético/Afetivo/Cognitivo em todos os materiais analisados (27). O Indicador Institucional esteve presente em 25 dos 27 materiais estudados.

Com relação aos atributos, verificamos que "Pesquisas científicas", "Papel do pesquisador no processo de produção do conhecimento" (Indicadores Científico) e "Identificação das instituições envolvidas na produção e fomento a ciência" e "Identificação da missão institucional" (Indicadores Institucional) não foram identificados em nenhum material durante nossa análise. Os demais atributos foram identificados durante as observações, como mostra o Quadro 2, abaixo.

Esse resultado indica que não era o objetivo das idealizadoras discutir as questões institucionais, de pesquisa e do pesquisador nos materiais educativos, como ficou demonstrado na fala de entrevistada 3 que diz que "O objetivo do material era ensinar sobre os animais, seu ambiente e ensinar as pessoas a conservar". Nem as entrevistas nem os documentos analisados fazem menção ao objetivo de tratar aspectos da instituição, da pesquisa ou do papel do pesquisador nos materiais educativos. O único momento em que existe uma referência ao Zôo de Sorocaba e suas funções é no acolhimento, como nos contou a entrevistada 3. Apesar da maioria dos materiais terem a identificação da instituição que os produziu, aspecto este fundamental, consideramos que este é um nível ainda muito frágil para explorar a dimensão institucional da $\mathrm{AC}$. 
Na Figura 29 apresentamos um gráfico para sintetizar a presença dos indicadores nos materiais educativos. Já na Figura 30 está o gráfico sintetizando a presença dos atributos nos materiais educativos.

Figura 29: Gráfico da ocorrência dos indicadores de $\mathrm{AC}$ nos materiais educativos do Zôo de Sorocaba

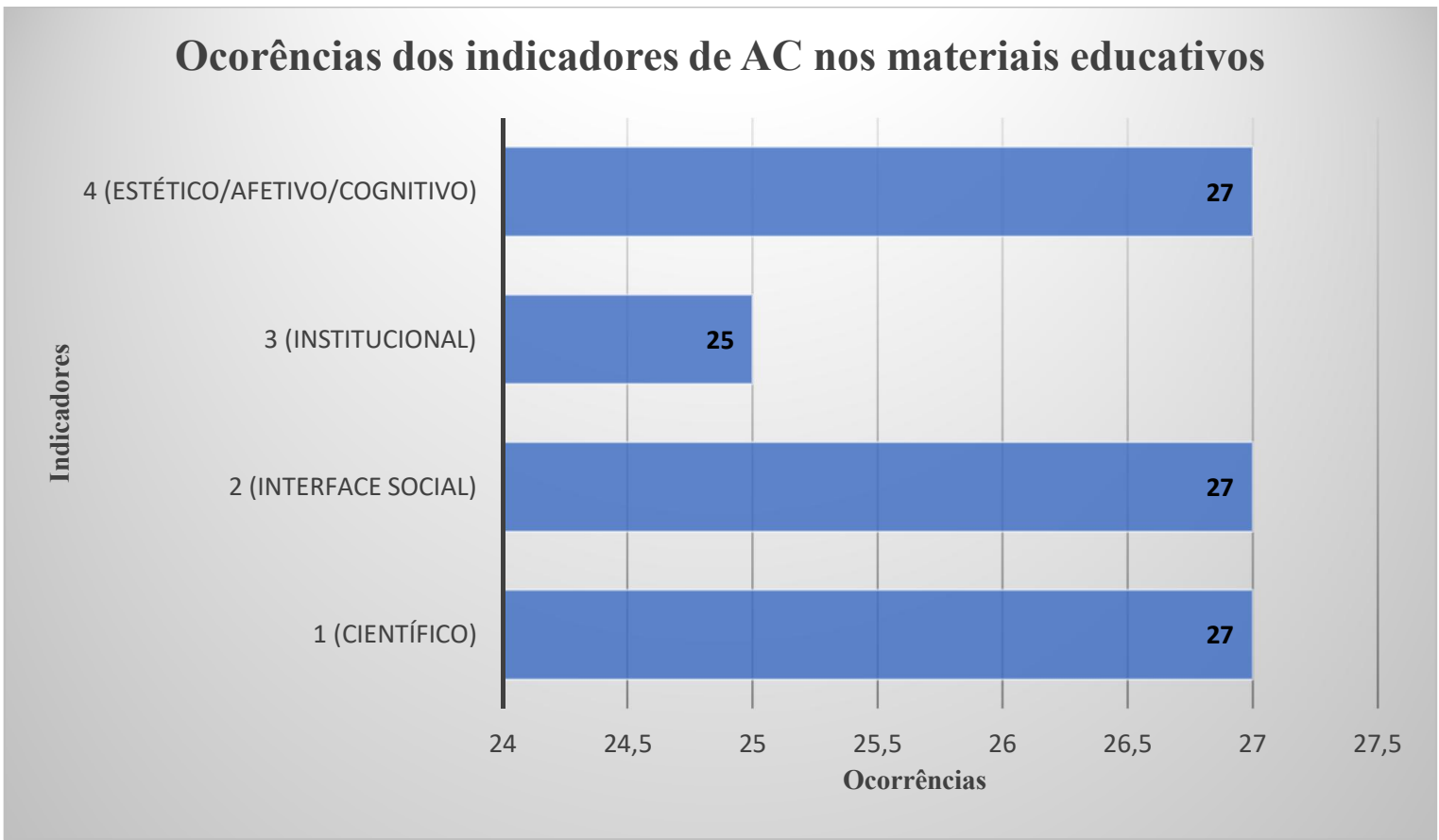


Figura 30: Gráfico da ocorrência dos atributos de AC nos materiais educativos do Zôo de Sorocaba

\section{Ocorrências dos atributos de AC nos materiais educativos}

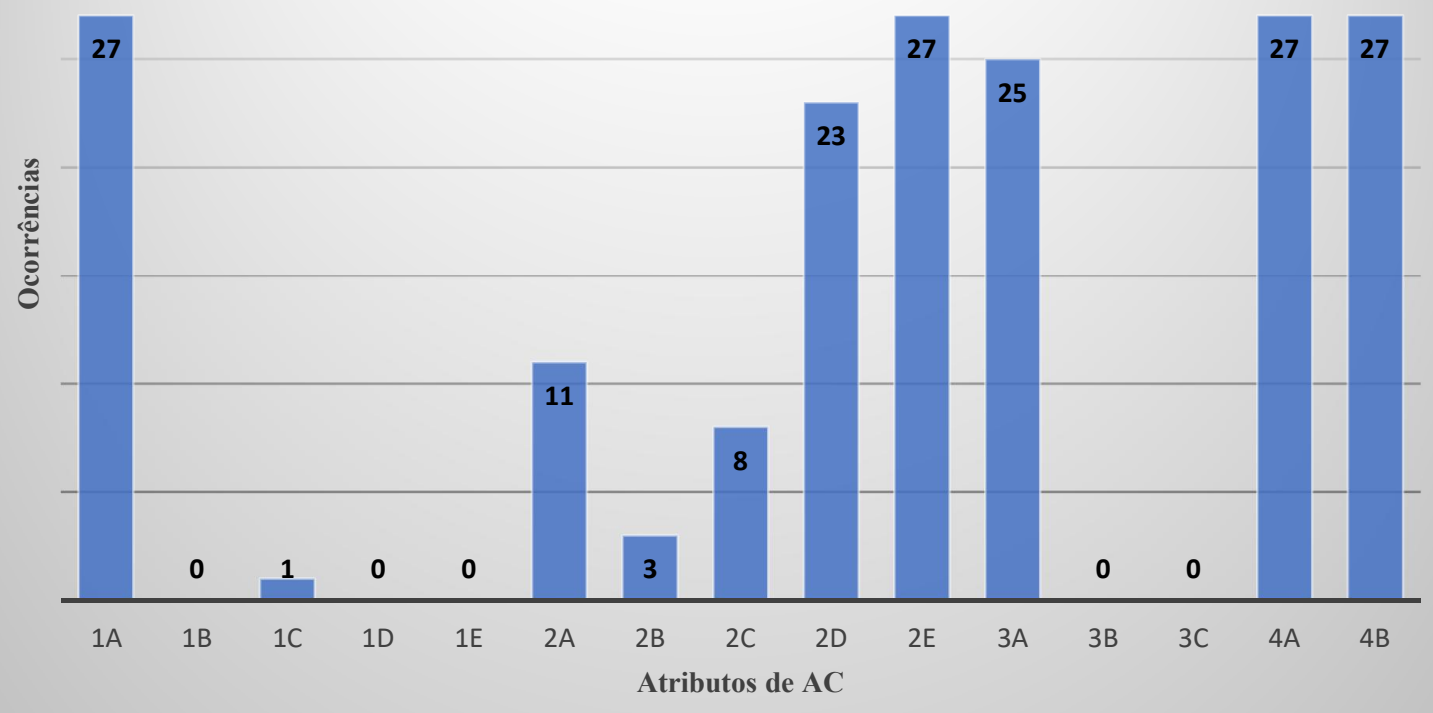

Tanto nas figuras acima quanto no quadro abaixo apresentamos a síntese dos indicadores e atributos encontrados durante nossa análise dos 27 materiais educativos do Zôo de Sorocaba. Dos 16 atributos existentes, identificamos a presença de 11 deles nos materiais analisados, isto é, $68 \%$ dos atributos estiveram presentes nos materiais educativos, segunda nossa análise. Isto nos aponta que esses materiais, mesmo não tendo sido produzidos com a perspectiva da $\mathrm{AC}$, contribuem para este processo principalmente em relação ao trabalho com conceitos e características dos animais. 
Quadro 2: Síntese da ocorrência de indicadores e atributos nos materiais educativos do Zôo de Sorocaba

\begin{tabular}{|c|c|c|}
\hline INDICADORES & ATRIBUTOS & $\begin{array}{l}\text { OCORRÊNCIA } \\
\text { NOS MATERIAIS }\end{array}$ \\
\hline \multirow{5}{*}{ CIENTÍFICO } & 1a - Conhecimentos e conceitos científicos e suas definições & $\mathrm{X}$ \\
\hline & 1b - Pesquisas científicas & \\
\hline & 1.c - Processo de produção de conhecimento científico & $\mathrm{X}$ \\
\hline & $\begin{array}{l}\text { 1.d - Papel do pesquisador no processo de produção do } \\
\text { conhecimento }\end{array}$ & \\
\hline & 1.e - Dinâmica interna da ciência & \\
\hline \multirow{5}{*}{$\begin{array}{l}\text { INTERFACE } \\
\text { SOCIAL }\end{array}$} & 2.a - Impactos da ciência na sociedade & $\mathrm{X}$ \\
\hline & 2.b - Influência da economia e política na ciência & $\mathrm{X}$ \\
\hline & 2.c - Influência e Participação da sociedade na ciência & $\mathrm{X}$ \\
\hline & 2.d - Identificação dos tipos de público & $\mathrm{X}$ \\
\hline & $\begin{array}{l}\text { 2.e - Ações e produtos de divulgação científica, educação } \\
\text { formal e não formal }\end{array}$ & $\mathrm{X}$ \\
\hline \multirow{3}{*}{ INSTITUCIONAL } & $\begin{array}{l}\text { 3.a - Identificação das instituições envolvidas na produção, } \\
\text { fomento e divulgação da ciência }\end{array}$ & $\mathrm{X}$ \\
\hline & 3.b - Identificação da missão institucional & \\
\hline & $\begin{array}{l}\text { 3.c - Presença de elementos políticos, culturais e sociais } \\
\text { ligados à instituição }\end{array}$ & \\
\hline \multirow{3}{*}{$\begin{array}{c}\text { ESTÉTICO } \\
\text { AFETIVO } \\
\text { COGNITIVO }\end{array}$} & 4.a - Estético e Afetivo & $\mathrm{X}$ \\
\hline & 4.b- Cognitivo & $\mathrm{X}$ \\
\hline & 4.c - Interação física e sensorial & $\mathrm{X}$ \\
\hline
\end{tabular}

\subsection{INTERAÇÃO DO PÚBLICO COM O MATERIAL EDUCATIVO "MOCHILA DE CURIOSIDADES"}

Para a análise das interações dos estudantes do ensino fundamental I com o material educativo "mochila de curiosidades" esta pesquisa utilizou-se dos dados coletados por Garcia (2006) no seu trabalho de mestrado durante uma visita orientada utilizando os objetos biológicos do material (Apêndice D). A visita é dirigida por um mediador que se utiliza dos objetos da mochila para promover discussões sobre assuntos relacionados à conceitos biológicos, 
conservação, características morfológicas dos animais, adaptações dos animais aos seus ambientes entre outros.

A "mochila de curiosidades" (Figuras 2a e 2b) é constituída por diversos tipos de objetos, modelos, réplicas e material de apoio a eles, que variam dependendo da época e do tipo de tema que se quer tratar. No momento da coleta de dados em Garcia (2006) os materiais eram a muda e guizo de cascavel, bico de tucano, crânio de onça, pata e ovo de ema e foram utilizados na análise das interações nesta pesquisa, buscando compreender a contribuição desses objetos no processo de alfabetização científica do público.

Apresentaremos a seguir a análise qualitativa e quantitativa com base na coleta de dados de Garcia (2006) e nos dados oriundos das entrevistas e dos documentos que dizem respeito a "mochila de curiosidades". A intenção foi caracterizar, com base nessas informações, os indicadores e atributos de AC que se expressam durante essas interações.

Para a análise dos dados construímos um quadro (Quadro 3) com a identificação do objeto biológico trabalhado, a identificação da SDR, o diálogo entre estudantes e mediador e os indicadores e atributos identificados (Apêndice G).

O conjunto de falas utilizadas como fonte deste estudo formava um total de 554 turnos (composto por cada fala de crianças, mediador ou professora). Deste total, utilizamos 295 turnos, já que buscamos focalizar a interação dos alunos com os objetos da mochila, portanto ficamos com os diálogos que se referissem a este momento. Os 295 turnos foram organizados na forma de sequências de diálogo representativos e formamos as 19 SDRs $(\mathrm{N}=19)$ para análise (Apêndices D e G). Lembrando que o critério de composição das SDRs foi identificar os momentos onde ocorria a interação dos sujeitos com o objeto da mochila. Nos trechos das SDRs abaixo, $\mathrm{M}$ é o mediador, $\mathrm{P}$ é o professor, $\mathrm{Cv}$ são várias crianças se manifestando ao mesmo tempo e $\mathrm{C} 1, \mathrm{C} 2, \mathrm{C} 3$... correspondem as falas das distintas crianças.

\section{A - INDICADORES E ATRIBUTOS DE AC NAS INTERAÇÕES ENTRE OBJETO E PÚBLICO}

Abaixo apresentamos nossa análise da presença dos indicadores e atributos de alfabetização científica nas interações dos estudantes com o material "mochila de curiosidades". 


\section{Indicador científico}

Este indicador, como vimos anteriormente, ressalta ações de divulgação científica que têm como objetivo contribuir para a AC e expressa a questão da natureza da ciência, fornecendo suporte para que o visitante construa seu conhecimento sobre assuntos científicos expostos. Este indicador apareceu em 17 SDRs durante nossa análise (Figura 35) e demonstra que a preocupação com o conhecimento em relação a conceitos zoológicos e ecológicos presente nas entrevistas e Relatórios Anuais analisados se consolida no momento da interação com os objetos. Relembramos que aspecto conceitual tem sido considerado um dos componentes fundamentais para a $\mathrm{AC}$ do cidadão, sendo bastante presente na interação do público com os objetos da mochila de curiosidades do Zoo. No entanto, como veremos a seguir, somente o atributo referente aos conceitos deste indicador está presente, estando os demais relacionados a aspectos da produção do conhecimento ausentes neste caso.

\section{Atributo la - Conhecimentos e conceitos científicos e suas definições}

Os conceitos, leis, teorias e ideias científicas gerais legitimadas pela ciência sobre os temas abordados foram identificados em 17 SDRs (Figura 36). Um exemplo pode ser visto nas SDRs 1 e 2 (abaixo, destaques em cinza), durante o diálogo entre as crianças e o mediador com o uso dos objetos da mochila (Figura 31). Neste caso, as crianças identificam o animal após observação do objeto e, na discussão sobre o peso do bico do tucano, fazem relações com a facilitação para o vôo. Outro exemplo é o da SDR 8, quando o mediador apresenta o guiso da cascavel e discute sobre a relação entre a quantidade de anéis e o crescimento da serpente

\section{SDR 1}

[As SDRs 1 e 2 acontecem em frente ao recinto dos tucanos, o mediador apresenta o animal vivo na exposição e depois os animais preservados]

1. M: Vamos dar uma olhada nesse bicho aqui, oh... que bicho que é esse aqui? [apontando para o tucano no recinto]

2. Cv: "Tucano".

3. Cv: "Arara".

4. M: "Arara ou tucano"?

5. Cv: "Tucano".

6. : M: Tucano, deixa eu abrir minha mochila mágica aqui, ninguém pode olhar aqui dentro. Pessoal vamos todos olhar para o bicho lá, todo mundo olhando para o tucano lá. Esse bico dele é comprido, né!"

7. Cv: "É".

8. M: "Mas será que este bico é pesado"?

9. Cv: É. 
SDR 2

22. M: "Olha o tamanho dele. O tamanho é quase o tamanho do bico dele, não é? E este bico, será que é pesado? "

1. C1: "Não, é leve".

2. M: "Porque será?"

3. C3: "Por quê? Porque ele já é pesado".

4. P: "Se fosse pesado, como iria ser para ele?".

5. M: "Se fosse pesado, como ia ser"?

6. C3: "Ele ia ficar assim, oh..."

7. C4: "Ele ia ficar caindo tio".

8. C5: "Tio, porque ele já morreu?"

9. C2: "Ô, professor se fosse pesado, daí ele não conseguia voar. "

10. M: "Vocês concordam comigo que se ele fosse pesado, ele ia voar assim. [neste momento o monitor imita o tucano voando com a cabeça para baixo]. Não ia voar assim com o bico para baixo assim, oh... caído, porque o tucano voa assim, oh... olha o tucano voando.".

SDR 8

[A SDR abaixo ocorre no serpentário do Zôo de Sorocaba, onde há serpentes vivas, filhotes e adultos]

163. M: Lembra do guizo que eu mostrei para vocês? Tem uma coisa engraçada na cascavel, toda vez que ela troca essa pele aqui, ela ganha um guizo. Se ela trocar três vezes, essa cobra, de pele ao ano, quantos guizos ela vai ganhar?"

164. Cv: "três."

165. M: "Se ela trocar uma vez no ano só?"

166. Cv: "Um."

167. M: "Se ela trocar duas vezes no ano?"

168. Cv: "Duas."

169. M: "Então é certo falar que a cobra tem cinco guizos. Então ela tem cinco anos."

170. C1: "É."

171. Cv: "Não."

172. M: "Não é. Cada vez que ela troca de pele, ela ganha um guizo. Ela pode trocar de pele duas, três vezes no ano, e esse guizo é muito frágil, pode quebrar muito fácil. Então não dá para saber a idade da cascavel, então, quanto mais barulho, mais velha ela é, mais guizo ela tem."

A ideia que permeia este atributo também esteve presente nas entrevistas, nos Relatórios Anuais e nas publicações visitadas, como podemos identificar na fala da entrevistada 2 quando menciona que o material tinha como objetivo trabalhar os conceitos científicos sobre morfologia. O Relatório Anual de 2009 vol. II, apresenta uma relação dos conceitos que devem ser trabalhados durante a interação com a mochila: alimentação do tamanduá, biomas, classificação dos animais entre outros (RELATÓRIO ANUAL, 2009). A dissertação de Garcia (2006) menciona que os objetos biológicos da "mochila de curiosidades" apresentam “... curiosidades intrínsecas relacionadas a sua forma, constituição, função, alimentação, 
locomoção, reprodução, defesa e camuflagem...” e que potencialmente possibilitam a discussão de conceitos biológicos que relacionam forma e função (Figura 31).

Figura 31: Interação dos alunos com o bico do tucano e guiso de cascavel, objetos da "mochila de curiosidades

Fotos de Viviane Garcia
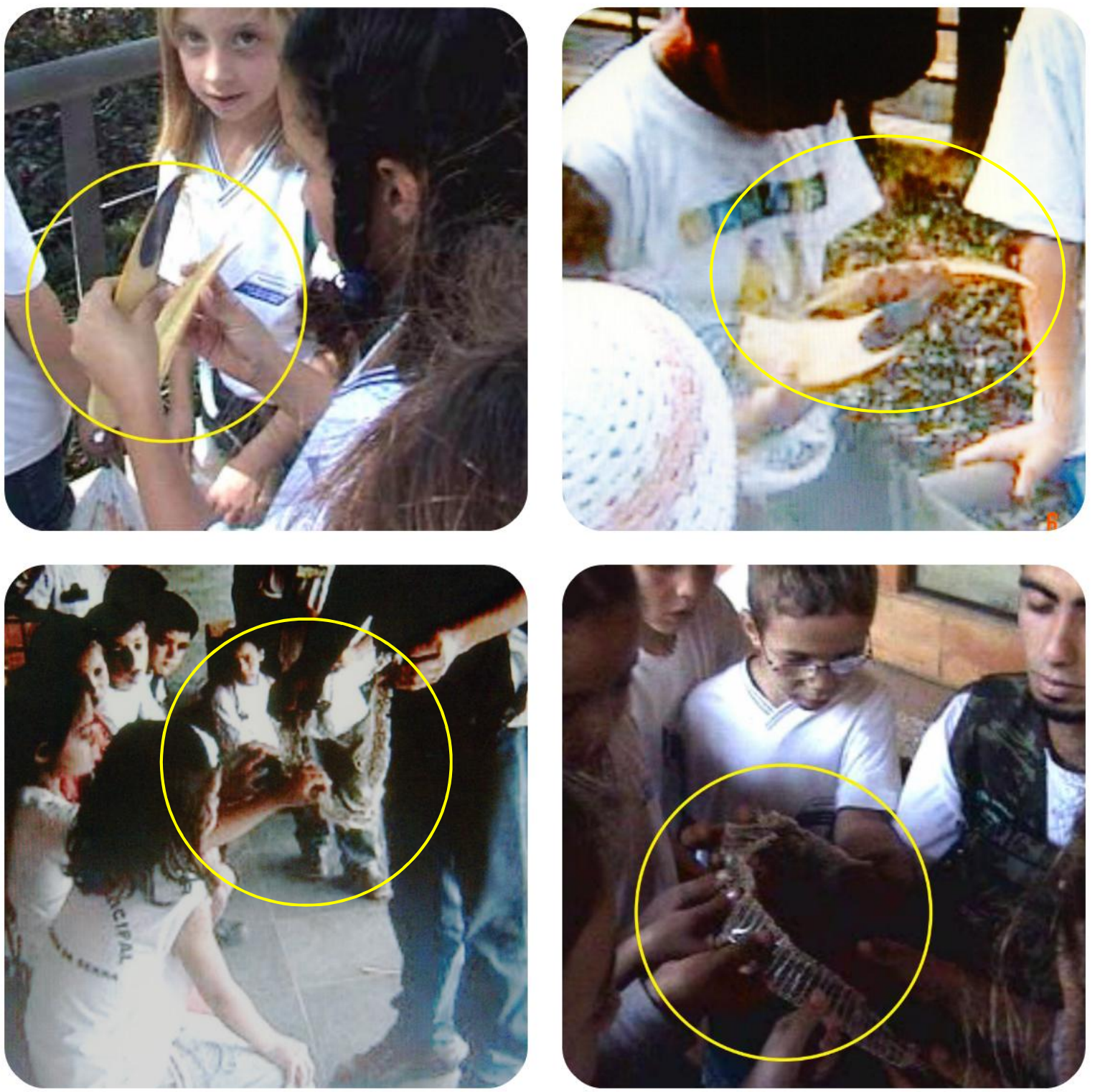

Atributo $1 b$ - Pesquisas científicas

Não encontrado 
Atributo 1c - Processo de produção de conhecimento científico

Não encontrado

Atributo 1d - Papel do pesquisador no processo de produção do conhecimento:

Não encontrado

Atributo le - Dinâmica interna da ciência:

Não encontrado

\section{Indicador Interface Social}

Este indicador está presente quando a ação de divulgação científica tem potencial para propiciar o entendimento do significado social da ciência e explorar as inter-relações entre a ciência, tecnologia, inovação e a sociedade, expressando aspectos dos impactos da ciência na sociedade, a influência da economia e política na ciência, a influência e participação da sociedade na ciência, a identificação dos tipos de público, as ações e produtos de divulgação científica, educação formal e não formal. Não identificamos nenhum dos atributos pertencentes a este indicador nas interações analisadas. No que se refere ao atributo "2.d Identificação dos tipos de público", gostaríamos de destacar que, por meio da análise do material, das entrevistas e dos relatórios tínhamos o conhecimento de que a mochila de curiosidades foi idealizada para ser utilizado com o público escolar, mas não identificamos, no diálogo entre mediador, crianças e professor, nenhuma referência à escola, ao conteúdo estudado, à aspectos do contexto escolar como materiais ou livros didáticos, relacionando com o que estava sendo mostrado e comentado pelo mediador. A professora também não fez nenhuma ligação do que as crianças estavam observando com o conteúdo estudado ou com outras experiências que os alunos possam ter tido com os conceitos discutidos durante a visita e, por esta razão, não identificamos este atributo nas interações.

\section{Indicador Institucional}

$\mathrm{O}$ indicador institucional expressa a dimensão das instituições envolvidas com a produção e o fomento da ciência e sua função social, permitindo identificar quais são instituições envolvidas, bem como aspectos políticos, científicos e culturais relacionados. Não identificamos este indicador e seus atributos durante as interações dos alunos com o material, já que nos diálogos não houve qualquer menção a dimensão institucional da ciência e de sua produção. 


\section{Indicador Estético/Afetivo/cognitivo}

O indicador estético-afetivo-cognitivo estará presente quando a ação de divulgação científica tem potencial para despertar dimensões relacionadas à afetividade, interação, percepção, motivação e aprendizagem. Quando aplicado para análise do público, se revela a partir das manifestações de sentimento e por meio de expressões e ações dos sujeitos que revelem operações epistêmicas e habilidades investigativas identificadas durante a interação com os materiais. Aponta se existe a possibilidade de diversas formas de acesso ao conhecimento, por diferentes tipos de público.

Este indicador apareceu com mais intensidade nas interações, tendo todos seus atributos sido identificados nas 19 SDRs selecionadas. Percebe-se, desse modo, que as dimensões afetivas, cognitivas e físicas apareceram de maneira significativa nas interações, como corroboradas pelas entrevistas e documentos que ressaltaram a importância da manipulação, do contato físico com os materiais para despertar o interesse e estimular a participação dos alunos. Um dos objetivos da produção da mochila era despertar a atenção e motivar os alunos a participarem da construção dos conhecimentos sobre os temas apresentados pelo mediador.

\section{Atributo $4 a$ - Estético e Afetivo}

Este atributo refere-se a uma ação ou produto que apresenta potencial para estimular manifestações de sentimentos como apreço, prazer, repulsa, indignação ou outras sensações, tanto em relação a ciência quanto a formato como ela está sendo apresentada. Além disso, possibilita momentos de contemplação e de apreciação estética e artística, oportunizando a expressão de experiências pessoais.

Este atributo foi identificado nas 19 SDRs durante a interação com o material. A SDR 9 nos mostra isso no momento em que o mediador oferece a muda da serpente para manuseio, a criança $\mathrm{C} 1$ demonstra um estranhamento e a $\mathrm{C} 2$ prazer no contato com o objeto. A C2 também demonstra afeto ao interagir com a muda de um filhote de serpente (Figura 31). Na SDR 13 identificamos este atributo quando várias crianças $(\mathrm{Cv})$ expressam certo desconforto e não querem pegar o crânio do tamanduá e também quando $\mathrm{C} 1$ demonstra carinho e diz que vai dar "um beijinho", como podemos ver no exemplo abaixo (destacados em cinza) (Figura 32). 
SDR9

[A SDR abaixo ocorre no serpentário do Zôo de Sorocaba, onde há serpentes vivas, filhotes e adultos]

193. M: "Oh, eu vou deixar segurar aqui, mas, oh devagar! Vamos passar a mão devagar! Não vamos ter pressa [neste momento o monitor deixa as crianças manusearem a muda da cobra cascavel]"

194. C1: "Ai, credo!"

195. C2: "Dá um beijinho! Deixa eu passar a mão no rabinho dela?

196. C1: "É mole, né!"

197. M: "Quando ela troca de pele, ela sai cheia de xixi, toda molhada, daí a gente lava ela e ela fica desse jeito aqui (o monitor mostra a pele). Então essa daqui já está quebrada, mas quando ela sai, ela sai perfeita. Oh! Esta aqui trocou de pele há pouco tempo."

198. C2: "Oh, filhotinho!

199. M: "Esta aqui é filhotinho de cascavel."

200. C2: "Tio, a pequenininha também troca de pele?"

201. M: “Oh, troca. Ela é quem troca mais, porque ela tá crescendo muito, em pouco

SDR 13

[A interação abaixo acontece em frente ao recinto do tamanduá-bandeira e começa após a observação do animal vivo]

415. M: “Oh, eu vou passar... Vocês vão passando para o amiguinho." (neste momento o monitor passa o crânio do tamanduá para manuseio).

416. Cv: "Eu não quero ver não." [um grupo de crianças continua olhando os animais e o outro vai manusear o crânio do tamanduá]

417. C2: "Eu quero."

418. C1: "Que beijinho dorme dorme...dá para mim depois..."

419. C4: "Alá, a linguona dele, tia.

420. C1: "Dá pra mim depois."

421. C3: "Alá, a gosmenta dele.". 
Figura 32: Interação dos alunos com o crânio de tamanduá, objeto da "mochila de curiosidades Fotos de Viviane Garcia
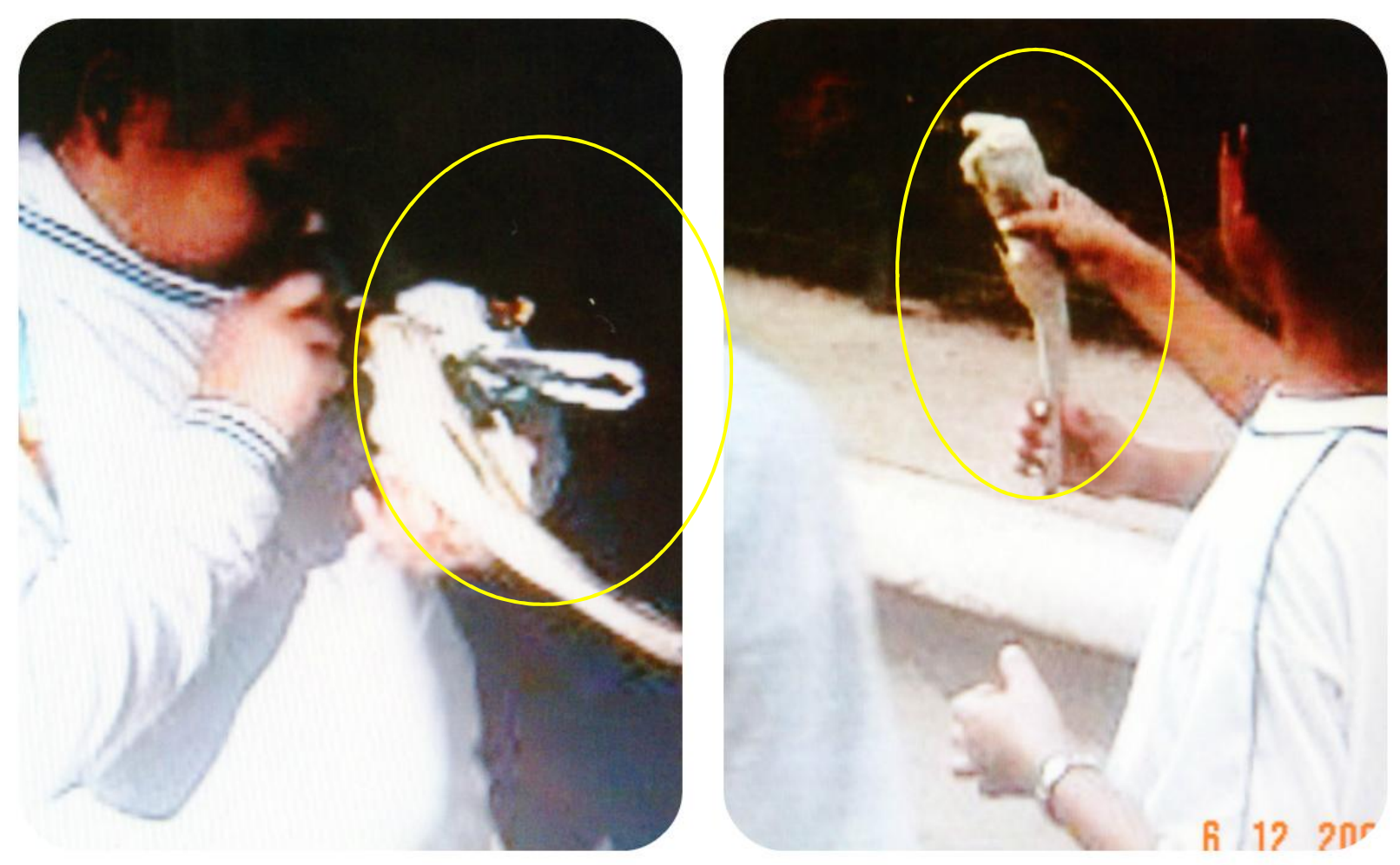

Atributo $4 b$ - Cognitivo

Este atributo pode ser identificado quando na interação dos sujeitos com os materiais identificase a promoção de habilidades relacionadas aos processos de investigação científica e operações epistêmicas como observação, nomeação, afirmação, comparação, caracterização, suposição, explicação, questionamento, emissão de opinião, conclusão e generalização, a partir da interação com o objeto. Identificamos este atributo nas 19 SDRs analisadas.

Abaixo apresentamos um exemplo da SDR 18 onde o mediador apresenta o crânio de onça pintada, pergunta para que servem os dentes caninos, compara com os das crianças e relaciona com a função deles, neste momento várias crianças levantam hipóteses sobre os dentes chegando à conclusão de que eles servem para rasgar o alimento (destaques em cinza) (Figura 33). Na SDR 12 percebemos que as crianças opinam sobre o animal ao qual o mediador se refere e levantam várias hipóteses até terem contato com o objeto (crânio de tamanduá) (destaque em cinza) (Figura 32). 
SDR 18

[Esta interação ocorre em frente ao recinto das onças pintadas]

464.M: "Para que, que serve esses dentões todo cheio de ponta?"

465. P: "Pra que será?"

466. Cv: "Para ele poder pegar as coisas."

467. M: "Pegar, como assim?"

468. C3: "Pega e coloca a pata."

469. M: "O nosso também dá para pegar."

470. C3: "Tio, pegar, colocar a pata e puxar.".

471. M: "Dá para rasgar, segurar assim?" [o monitor mostra com as mãos].

472. C3: "É."

473. M: "Muito bem! Esse dentão dele aqui serve pra rasgar... se fosse pra morder pra poder matar o bicho... esse aqui oh, serve pra rasgar..."

474. C1: "O tio a gente vai ver agora, a gente vai catar." [a criança quer manusear o objeto].

475. M: "Oh, de todos os gatos que tem no mundo todo, a onça-pintada é o maior do Brasil. Vocês sabem que a onça é um gato? O leão também é um gato, o tigre também é um gato. Oh, o tigre é o maior gato do mundo."

476. C1: "Ele é famoso."

477. M: "É o do Brasil, o maior gato é a onça-pintada."

\section{SDR 12}

[A interação abaixo acontece em frente ao recinto do tamanduá-bandeira e começa após a observação do animal vivo]

297. M: “Atenção, turminha! Turminha vem cá! Que bicho será que é aquele?"

298. C1: "Tamanduá."

299. M: "Tamanduá, o que?"

300. Cv: "Bandeira."

301. M: "Tamanduá bandeira, muito bem! Gente vou pegar uma coisinha para vocês darem uma olhadinha. Pessoal, o que é isso?" [neste momento o monitor apresenta o crânio de tamanduá e até as crianças de outra escola que estão em frente ao recinto do tamanduá se interessam pelo objeto e começam a participar].

302. Cv: "Bico."

303. Cv: "É a cabeça dele."

304. C3: "É o focinho."

305. M: "Um bico? É um tucano para ter bico?"

306. C3: "Não, é o focinho dele."

307. Cv: "É a boca."

308. Cv: "A perna."

309. Cv: "A cocha."

310. M: "Gente, esse aqui é um crânio de tamanduá bandeira. Esse aqui é a cabeça dele. Vamos dar uma olhada no bicho lá. Olha a língua dele, olha a língua dele." 
Figura 33: Interação com o crânio da onça pintada. Crianças comparando os dentes caninos do animal com os próprios dentes Foto de Viviane Garcia.

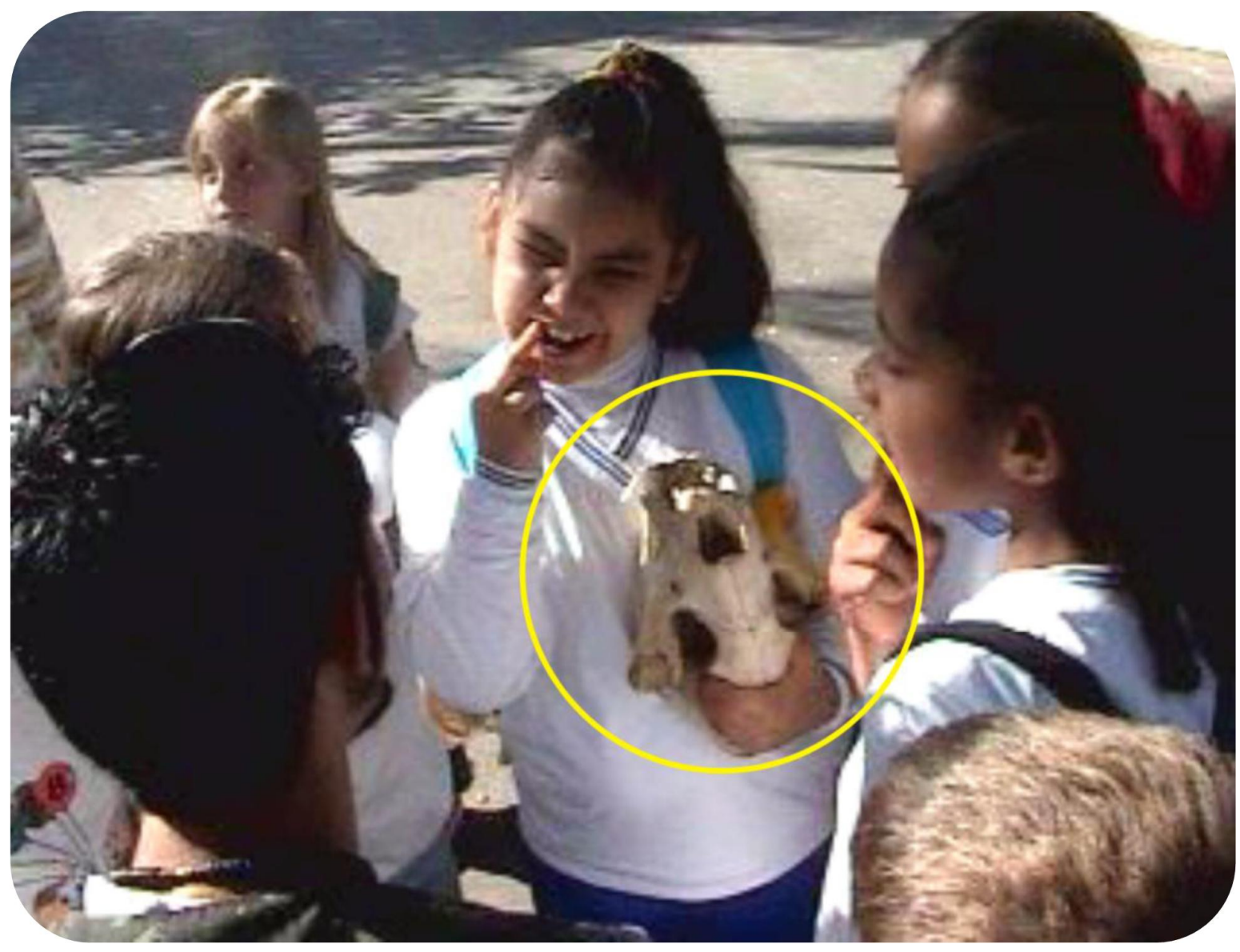

O Relatório Anual de 2001/2002 afirma que o material tinha como um dos objetivos auxiliar no conhecimento das características biológicas e ecológicas e estimular a discussão sobre a relação entre forma e função dos animais bem como estimular diálogo entre os estudantes sobre curiosidades da morfologia doa animais durante a manipulação. (RELATÓRIO ANUAL, 2001/2002). A entrevistada 3 menciona que o material deveria fornecer o máximo de recursos para ilustrar a conversa do mediador com o estudante e chamar atenção da criançada para as questões, estimular a argumentação e facilitar a mediação. Assim vemos que a dimensão cognitiva da $\mathrm{AC}$ foi pretendida na elaboração da mochila e efetivamente se manifesta na interação do público com os objetos existentes nela. 


\section{4.c - Interação física e sensorial}

Esse atributo considera os diversos níveis de interatividade física e sensorial com o produto ou objeto e, ainda, busca identificar se, na interação com o objeto, há o estimulo a relação entre os diversos atores envolvidos e se há valorização dos conhecimentos prévios do público.

Identificamos este atributo em todas as SDRs analisadas pois em todos os momentos houve manipulação dos objetos da mochila pelo público (Figura 31, 32, 33, 34). Na SDR 5 (destacado em cinza) as crianças conversam com o mediador sobre o peso do bico e depois experimentam o peso manipulando o objeto. Também manipulam o bico do tucano sentindo o serrote que auxilia o animal a quebrar as sementes que fazem parte de sua alimentação (Figura 31). Na SDR 11 podemos identificar também que o contato com a pata da ema (que é enorme) desencadeia uma discussão do tipo de locomoção dessa ave levando a uma conclusão baseada na experiência concreta com esse objeto (Figura 34).

\section{SDR 5}

[Esta interação ocorre em frente ao recinto do tucanos]

81. M: "Oh, eu vou fazer o seguinte, vou passar para vocês. Tem que tomar super... cuidado, é super precioso este daqui."

82. C4: "É de ouro."

83. P: "Não. É um bico leve."

84. C1: "É especial. É único, né tio?"

85. M: "Não, a gente tem mais aqui. Mas olha só, quem vai pegar nele vai falar se ele é leve ou pesado. É muito leve né! Nem parece que é desse jeito. Parece ser super leve e ele nem é muito forte."

86. C2: "É sim, tio!"

87. C2: "Igual a um serrote. [o aluno manuseia o bico e passa o dedo na fase interior do bico, serrilhada]"

88. M: "O tucano come semente e um monte de frutas." [neste momento as crianças estão manuseando o bico do tucano].

\section{SDR 11}

[Esta SDR ocorre em frente ao recinto das emas antes da observação do animal vivo]

252. M: "Vou pegar uma coisinha aqui. Olhe o tamanho da pata da ema." [neste momento o monitor apresenta a pata e as crianças ficam juntas vendo com cara de espanto e curiosidade].

253. C1: "Ahh..."

254. M: "Essa é uma pata de ema."

255. C1: "E que morreu?"

256. M: "Ela já morreu, já. Será que ela voa, corre ou nada?'

257. C3: "Nada."

258. Cv: "Corre."

259. C1: "Corre."

260. C3: "Ema lá, a ema ali, oh" [a criança conduz o grupo a olhar a ema do recinto]. 
261. M: "Por que ela precisa dessa patona grandona?"

262. C1: "Para correr."

263. Cv: "Pra correr."

264. M: Quem acha que é correr, levanta a mão

265. C1: pra se coçar também.

266.M: "Pra se coçar também, pode ser. Muito bem, quem falou que era para correr, era para correr mesmo. Ela corre muito.

Figura 34: Pata de ema durante interação dos objetos da mochila com as crianças Fotos Viviane Rachid

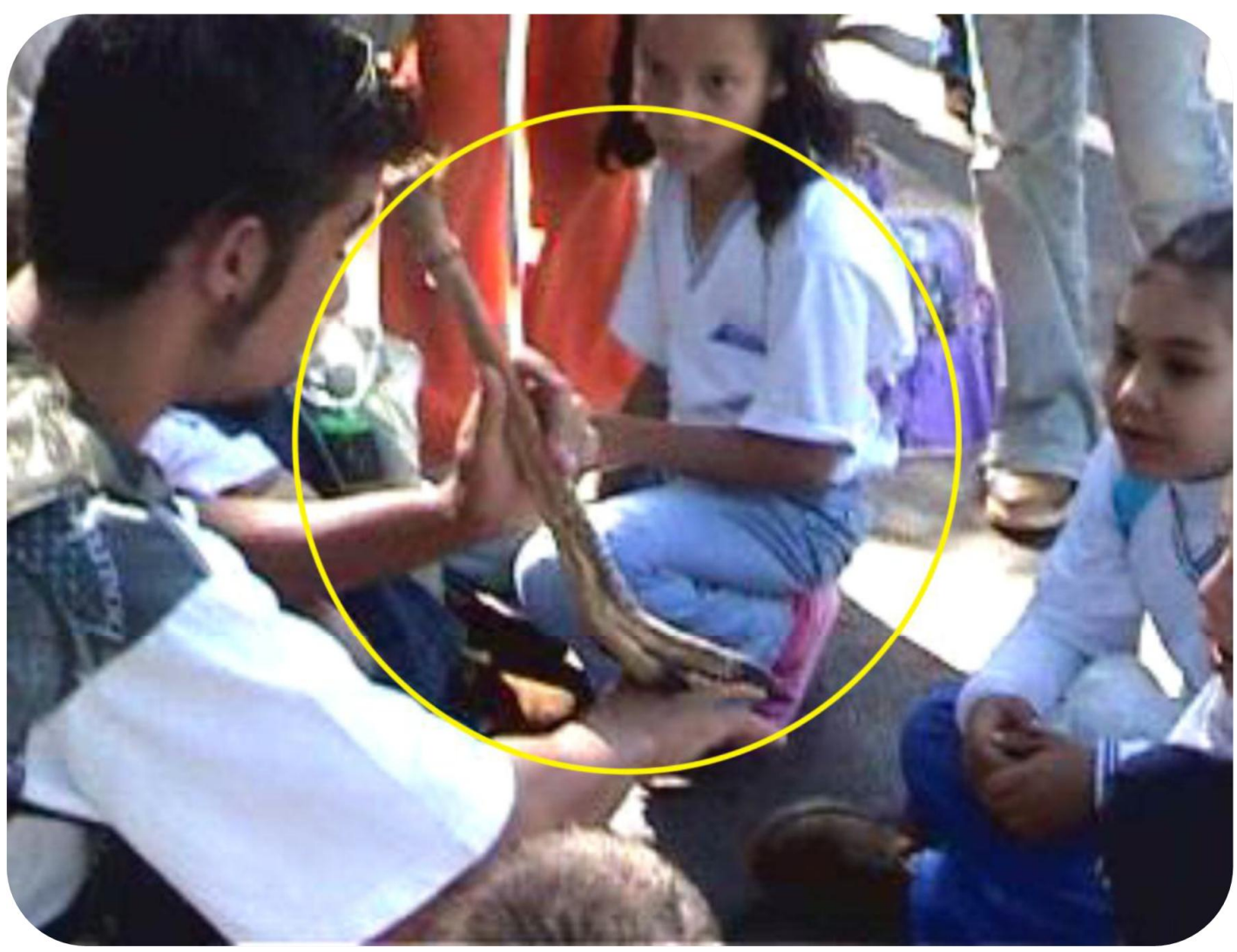

A mochila, em sua concepção, pressupõe a ideia de que o público possa tocar nas peças anatômicas e isso é estimulado fortemente pelo mediador durante a visita. A preocupação com a questão refletida neste atributo também estava presente nas entrevistas e nos Relatórios Anuais consultados. Podemos perceber nas falas da entrevistada 3 a preocupação e a intenção de produzir materiais que permitissem uma interação física e sensorial "A produção das mochilas surgiu do fato de eu ser educadora e ter a preocupação de tornar as visitas mediadas mais concretas e interativas" $\mathrm{e}$ "... as crianças terem um momento de vivenciar, de ter uma experiência única, de viver aquele momento único, de poder ter o contato". Um dos relatórios anuais (RELATÓRIO ANUAL, 2003) também menciona o objetivo de dar acesso e enriquecer 
a visita, como vemos a seguir “... para enriquecer a metodologia utilizada em várias atividades educativas do Zôo, entre elas, a mediação".

Sintetizando a ocorrência dos indicadores de AC durante a interação dos alunos com a "mochila de curiosidades" tivemos: presença de 2 indicadores - científico e estético/afetivo/cognitivo. Não identificamos os indicadores institucional e interface social. $\mathrm{O}$ indicador estético/afetivo/cognitivo apareceu nas 19 SDRs e o científico apareceu em 17, conforme Figura 35.

Figura 35: Gráfico das ocorrências dos indicadores de AC durante a interação dos estudantes com a "mochila de curiosidades" do Zôo de Sorocaba

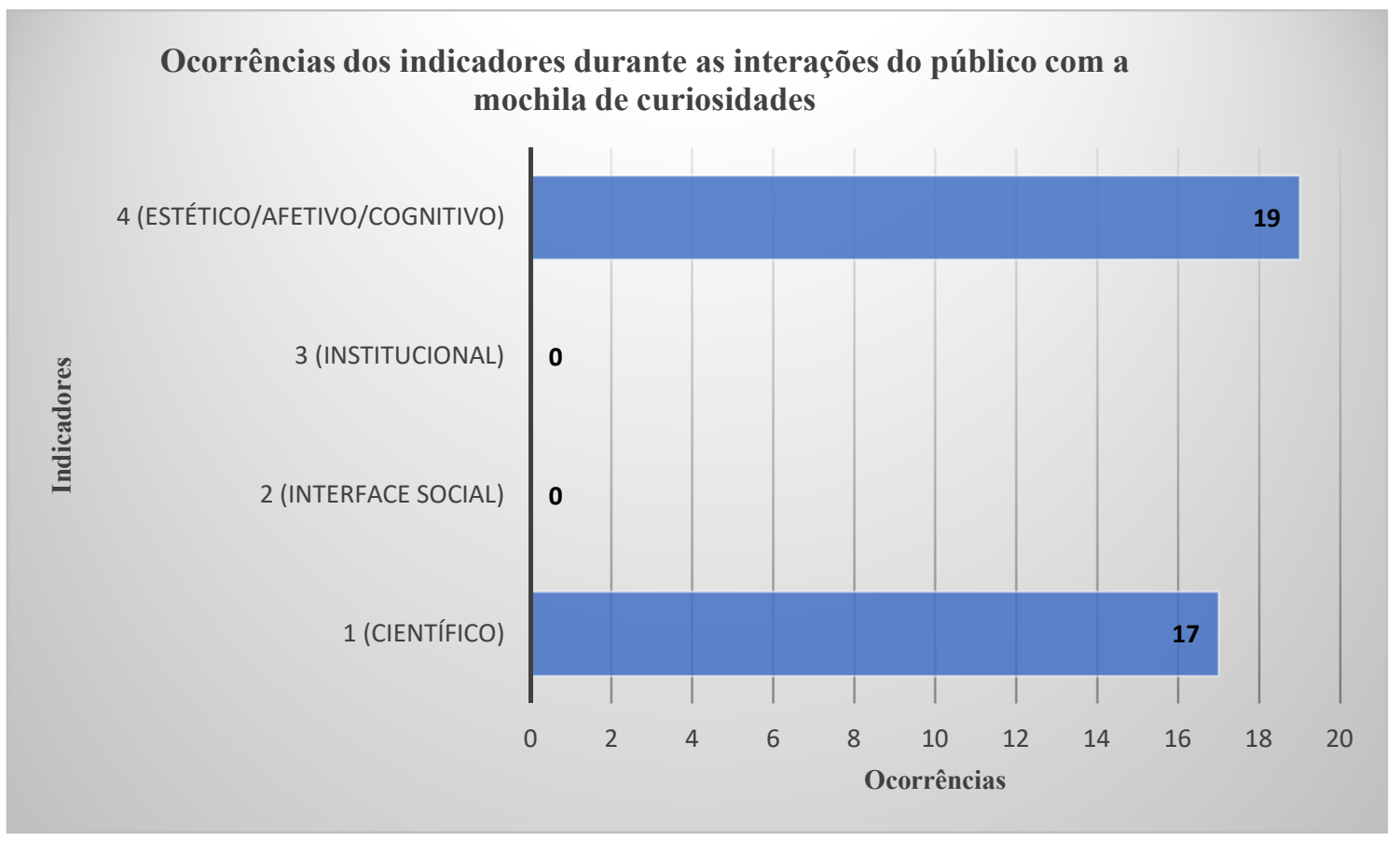

A incidência destes indicadores se confirma também nas entrevistas e documentos analisados como em uma das falas da entrevistada 2 que diz que ela observou durante a interação dos estudantes com os objetos da "mochila de curiosidades", uma grande motivação e atenção redobrada dos estudantes e acha que foi um estimulador de discussões sobre os conceitos tratados na visita. $\mathrm{O}$ aspecto conceitual relacionado ao indicador científico, que foi identificado em 17 SDRs, também foi bastante destacado nas entrevistas e documentos analisados como um dos objetivos para a produção da mochila. 
Na Figura 36 temos a síntese da ocorrência dos atributos nas interações dos estudantes com a "mochilas curiosidades". Identificamos a presença de 4 atributos dos 16 existentes ligados aos conceitos e interação afetiva, cognitiva e física. Estes aspectos também foram mencionados pelas idealizadoras do material nas entrevistas, que dizem que o objetivo deste material é tratar conceitos referentes à morfologia e relacioná-la ao hábito e comportamento de cada animal. Nos documentos também identificamos que a ideia dos materiais era proporcionar contato com os objetos originais para auxiliar na atenção e motivação dos estudantes.

Figura 36: Gráfico das ocorrências dos atributos de AC durante a interação dos estudantes com o material "mochila de curiosidades" do Zôo de Sorocaba

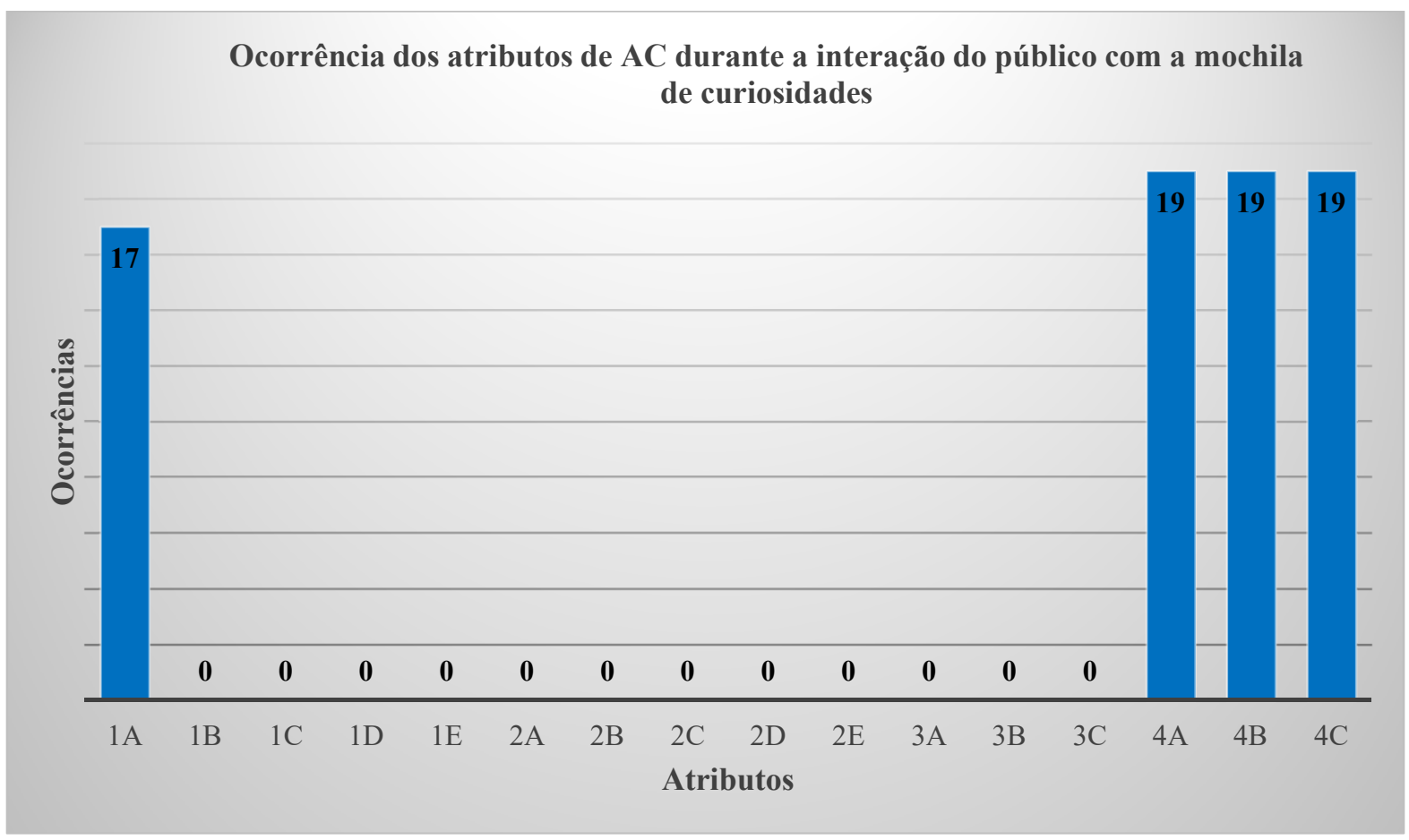

No quadro abaixo (Quadro 4) apresentamos uma síntese dos indicadores e atributos identificados no material "mochila de curiosidades" após nossa análise e comparamos com os atributos que apareceram nas interações dos estudantes com o mesmo material. $\mathrm{Na}$ análise das intenções e proposta deste material, dos 16 atributos existentes, 10 deles (62,5\%) foram identificados na "mochila de curiosidades", segundo nossa análise (Quadro 1). Já nas interações dos estudantes com os objetos da mochila, conseguimos identificar apenas 4 atributos $(25 \%)$ dos 16 existentes em nossa ferramenta de análise do processo de AC. Essa 
diferença, assim como as implicações dos resultados obtidos serão discutidos mais adiante nesta pesquisa.

Quadro 4: Síntese da ocorrência de indicadores e atributos comparando o material educativo "mochila de curiosidades" a partir de nossa análise com as interações dos alunos

\begin{tabular}{|c|c|c|c|}
\hline INDICADORES & ATRIBUTOS & $\begin{array}{l}\text { CONCEPÇÃO DA } \\
\text { MOCHILA DE } \\
\text { CURIOSIDADES }\end{array}$ & $\begin{array}{l}\text { INTERAÇÃO } \\
\text { DOS ALUNOS }\end{array}$ \\
\hline \multirow{5}{*}{ CIENTÍFICO } & $\begin{array}{l}\text { 1a - Conhecimentos e conceitos científicos e } \\
\text { suas definições }\end{array}$ & - & $X$ \\
\hline & 1b - Pesquisas científicas & & \\
\hline & $\begin{array}{l}\text { 1.c - Processo de produção de conhecimento } \\
\text { científico }\end{array}$ & $\mathrm{X}$ & \\
\hline & $\begin{array}{l}\text { 1.d - Papel do pesquisador no processo de } \\
\text { produção do conhecimento }\end{array}$ & & \\
\hline & 1.e - Dinâmica interna da ciência & & \\
\hline \multirow{5}{*}{$\begin{array}{l}\text { INTERFACE } \\
\text { SOCIAL }\end{array}$} & 2.a - Impactos da ciência na sociedade & $\mathrm{X}$ & \\
\hline & $\begin{array}{l}\text { 2.b - Influência da economia e política na } \\
\text { ciência }\end{array}$ & & \\
\hline & $\begin{array}{l}\text { 2.c - Influência e Participação da sociedade } \\
\text { na ciência }\end{array}$ & $\mathrm{X}$ & \\
\hline & 2.d - Identificação dos tipos de público & $\mathrm{X}$ & \\
\hline & $\begin{array}{l}\text { 2.e - Ações e produtos de divulgação } \\
\text { científica, educação formal e não formal }\end{array}$ & $\mathrm{X}$ & \\
\hline \multirow{3}{*}{ INSTITUCIONAL } & $\begin{array}{l}\text { 3.a - Identificação das instituições } \\
\text { envolvidas na produção, fomento e } \\
\text { divulgação da ciência }\end{array}$ & $\mathrm{X}$ & \\
\hline & 3.b - Identificação da missão institucional & & \\
\hline & $\begin{array}{l}\text { 3.c - Presença de elementos políticos, } \\
\text { culturais e sociais ligados à instituição }\end{array}$ & & \\
\hline \multirow{3}{*}{$\begin{array}{l}\text { ESTÉTICO } \\
\text { AFETIVO } \\
\text { COGNITIVO }\end{array}$} & 4.a - Estético e Afetivo & $\mathrm{X}$ & $\mathrm{X}$ \\
\hline & 4.b-Cognitivo & $\mathrm{X}$ & $\mathrm{X}$ \\
\hline & 4.c - Interação física e sensorial & $\mathrm{X}$ & $\mathrm{X}$ \\
\hline
\end{tabular}




\subsection{CRITÉRIOS DE VALIDAÇÃO E PROCEDIMENTOS DE CREDIBILIDADE DOS DADOS}

Como indicamos na metodologia, uma parte dos dados desta pesquisa (aplicação dos indicadores e atributos nos materiais educativos) foi analisada também por duas pesquisadoras do GEENF (Grupo de Estudo e Pesquisa em Educação Não Formal e Divulgação da Ciência) que estão familiarizadas com o quadro teórico utilizado. Gostaríamos de destacar que as pesquisadoras que validaram nossos dados não tiveram acesso às entrevistas e aos documentos analisados, somente à tabela de observação (Quadro 1, Apêndice E). Os resultados não foram rediscutidos com as pesquisadoras que fizeram as validações.

A tabela abaixo (Tabela 1) apresenta os números absolutos e as porcentagens de concordância entre a análise dos indicadores feitas por nós e pelas pesquisadoras que validaram os resultados.

Tabela 1: Comparação entre a análise dos indicadores presentes nos materiais feita por nós e pelas pesquisadoras do GEENF

\begin{tabular}{c|c|c|c|c|c}
\hline Indicadores de AC & Pesquisadora & Validação 1 & $\begin{array}{c}\text { \% de } \\
\text { concordância }\end{array}$ & Validação 2 & $\begin{array}{c}\text { \% de } \\
\text { concordância }\end{array}$ \\
\hline 1 (Científico) & 27 & 22 & 81,48 & 24 & 88,88 \\
\hline 2 (Interface social) & 27 & 5 & 18,51 & 27 & 100 \\
\hline 3 (Institucional) & 25 & 2 & 8 & 24 & 96 \\
\hline 4 (Estético/afetivo/cognitivo) & 27 & 18 & 66,66 & 0 & 0 \\
\hline
\end{tabular}

Notamos que na validação 1 obtivemos $81,48 \%$ de concordância com nossos resultados no Indicador Científico e na validação 2 obtivemos $88,88 \%$. Isto nos indica que o trabalho com os conceitos é muito valorizado pelo Zôo de Sorocaba, como pudemos conferir nas entrevistas e documentos apresentamos nos capítulos anteriores, e que ele aparece nos materiais observados. As pesquisadoras também identificaram este dado no momento da análise do Quadro 1.

No Indicador Interface Social tivemos $18,51 \%$ de coincidência na validação 1 e $100 \%$ na validação 2. As entrevistas e documentos nos mostraram que os materiais foram idealizados para serem trabalhados, prioritariamente, com o público escolar e que tinha a intenção de divulgar informações sobre os animais do Zôo de Sorocaba e relacioná-los com os ambientes em que vivem. Observamos este dado nas colunas INDICAÇÃO DE QUANDO USAR E INDICAÇÃO DE COMO USAR do Quadro 1. 
O Indicador Institucional apareceu quando identificamos a autoria dos materiais educativos pela equipe do Zôo de Sorocaba nos manuais para o professor (coluna AUTORIA do Quadro 1). A validação 1 coincidiu em $8 \%$ das observações dos materiais e a validação 2 em $96 \%$.

No Indicador Estético/afetivo/cognitivo observamos $66,66 \%$ de coincidência entre a observação da pesquisadora 1 e a nossa observação. A pesquisadora 2 considerou que este indicador não apareceu em nenhum material observado. Coluna INDICAÇÃO DE COMO USAR do Quadro 1, é possível identificar a sugestão de manipulação no guia para o professor.

Na Figura 37 apresentamos o gráfico comparando a análise dos indicadores feitas por nós e pelas duas pesquisadoras do GEENF.

Figura 37: Gráfico comparando os resultados da análise dos indicadores presentes nos materiais educativos realizada por nós e a validação por duas pesquisadoras do GEENF

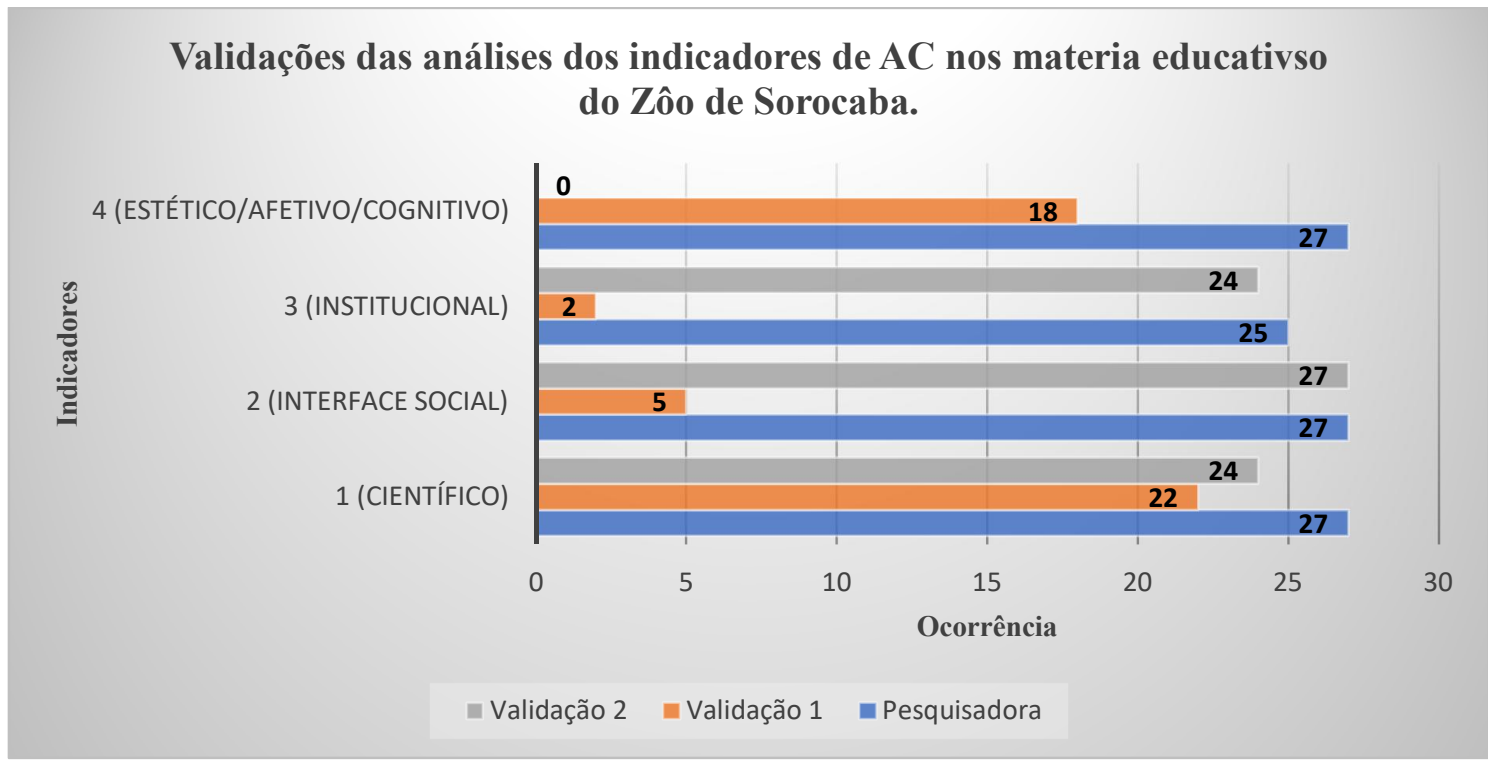

$\mathrm{Na}$ abaixo (Tabela 2) apresentamos os números absolutos e as porcentagens de concordância entre a análise dos atributos feitas por nós e pelas pesquisadoras que validaram os resultados. 
Tabela 2: Comparação entre a análise dos atributos presentes nos materiais feita por nós e pelas pesquisadoras do GEENF

\begin{tabular}{c|c|c|c|c|c}
\hline $\begin{array}{c}\text { Atributos de } \\
\text { AC }\end{array}$ & Pesquisadora & Validação 1 & $\begin{array}{c}\text { \% de } \\
\text { concordância }\end{array}$ & Validação 2 & $\begin{array}{c}\text { \% de } \\
\text { concordância }\end{array}$ \\
\hline 1A & 27 & 22 & 81,48 & 24 & 88,88 \\
\hline 1B & 0 & 0 & 100 & 0 & 100 \\
\hline 1C & 1 & 0 & 0 & 18 & 66,66 \\
\hline 1D & 0 & 0 & 100 & 0 & 100 \\
\hline 1E & 0 & 0 & 100 & 0 & 100 \\
\hline 2A & 11 & 1 & 9,09 & 7 & 63,63 \\
\hline 2B & 3 & 3 & 100 & 2 & 66,66 \\
\hline 2C & 8 & 2 & 25 & 3 & 37,5 \\
\hline 2D & 23 & 0 & 0 & 19 & 82,6 \\
\hline 2E & 27 & 0 & 0 & 27 & 100 \\
\hline 3A & 25 & 2 & 8 & 24 & 96 \\
\hline 3B & 0 & 0 & 100 & 0 & 100 \\
\hline 3C & 0 & 0 & 100 & 0 & 100 \\
\hline 4A & 27 & 1 & 3,7 & 0 & 0 \\
\hline 4B & 27 & 17 & 62,96 & 0 & 0 \\
\hline 4C & 27 & 0 & 0 & 0 & 0 \\
\hline
\end{tabular}

No atributo 1A, relacionado a conhecimentos e conceitos científicos e suas definições, obtivemos $81,48 \%$ de concordância na validação 1 e $88,88 \%$ na validação 2 . Isto nos indica que a maioria dos materiais carregam este atributo como corroborado pelas entrevistas e documentos.

No atributo 1B, 1D e 1E que não apareceram em nenhum material segundo nossas observações, obtivemos $100 \%$ de concordância nas duas validações.

No atributo 1C não obtivemos concordância com as validações 1 e 2 . A pesquisadora que realizou a validação 1 não observou este atributo nos materiais; e a pesquisadora que realizou a validação 2 observou-o em 18 materiais. Provavelmente a pesquisadora 2 considerou que os materiais de divulgação constituem parte do processo de produção do conhecimento científico.

No atributo 2A obtivemos baixa concordância com a validação 1 e média com a validação 2 . Este atributo refere-se ao impacto da ciência na sociedade, que foi considerado por nós presentes nos materiais no momento em que eles podem, potencialmente, possibilitar a discussão de ideias científicas de conservação ambiental, ligando essas ideias a dois temas reconhecidos como fundamentais para a manutenção da sociedade e do planeta: a conservação do ambiente e da biodiversidade. 
No atributo 2B obtivemos mais de $50 \%$ de concordância com as duas validações. Neste caso também o conteúdo e os objetos podem, potencialmente, estimular discussões sobre fatores políticos e econômicos que influenciam as pesquisas científicas, pois a temática dos materiais está diretamente relacionada com a vida humana, interesses comerciais em relação à destruição de ambiente e ameaça de extinção de animais, principalmente mamíferos e utilização de defensivos agrícolas matando polinizadores que diminuiriam a produção de alimentos.

No atributo $2 \mathrm{C}$ obtivemos $25 \%$ e $37 \%$ de concordância respectivamente com as validações 1 e 2. Este atributo está diretamente relacionado à participação da sociedade nas decisões sobre temas que se julguem importantes serem pesquisados ou que estejam relacionados à vida das pessoas quando se discutem as parasitoses que afetam o ser humano, lixo e poluição do mar.

No atributo 2D (identificação do público alvo) não houve concordância com a validação 1 e houve $82,6 \%$ de concordância com a validação 2. Ressaltamos que o público alvo está especificado na maioria dos materiais quando há a indicação, no manual para o professor, de quando utilizá-lo (coluna INDICAÇÃO DE QUANDO USAR, Quadro 1).

No atributo 2E, Ações e produtos de divulgação científica, educação formal e não formal, não houve concordância com a validação 1 e houve $100 \%$ de concordância com a validação 2 . Como nos mostraram as entrevistas e os documentos, um dos objetivos do material é a divulgação científica.

No atributo 3a (Identificação das instituições envolvidas na produção, fomento e divulgação da ciência) houve $8 \%$ de concordância com a validação 1 e $96 \%$ com a validação 2 . Consideramos que o atributo está presente no momento em que a autoria dos materiais é expressadas nos manuais para o professor (Coluna INDICAÇÃO DE QUANDO USAR, Quadro 1).

Os atributos 3B (Identificação da missão institucional) e 3C (Presença de elementos políticos, culturais e sociais ligados à instituição) não apareceram na nossa análise e houve concordância de $100 \%$ com as duas validações.

No atributo 4B (Cognitivo), houve concordância com a validação 1 (62,96\%), mas não houve concordância com a validação 2. Este tributo foi identificado por nós quando notamos os itens na coluna CONTEÚDO, Quadro 1, que pode ser potencialmente um momento em que o professor discuta conceitos de Biologia, Ciências e Educação Ambiental com os alunos. As entrevistas e documentos mencionam essa intenção no momento da idealização do material. No 
entanto, as pesquisadoras que validaram esta parte do trabalho não entraram em contato com as entrevistas e documentos.

Com relação aos atributos 4A (Estético e Afetivo) e 4C (Interação física e sensorial) não houve concordância com as validações 1 e 2. Na coluna INDICAÇÃO DE COMO USAR, Quadro 1, identificamos sugestões de manipulação dos materiais. Atribuímos esta ocorrência, novamente ao fato de as pesquisadoras não terem tido acesso às entrevistas e aos documentos que mencionam que os materiais podem ser manipulados.

Na Figura 38 apresentamos a comparação entre a análise dos atributos feita por nós e pelas pesquisadoras do GEENF.

Figura 38: Gráfico comparando os resultados da análise dos atributos presentes nos materiais educativos realizada por nós e a validação por duas pesquisadoras do GEENF

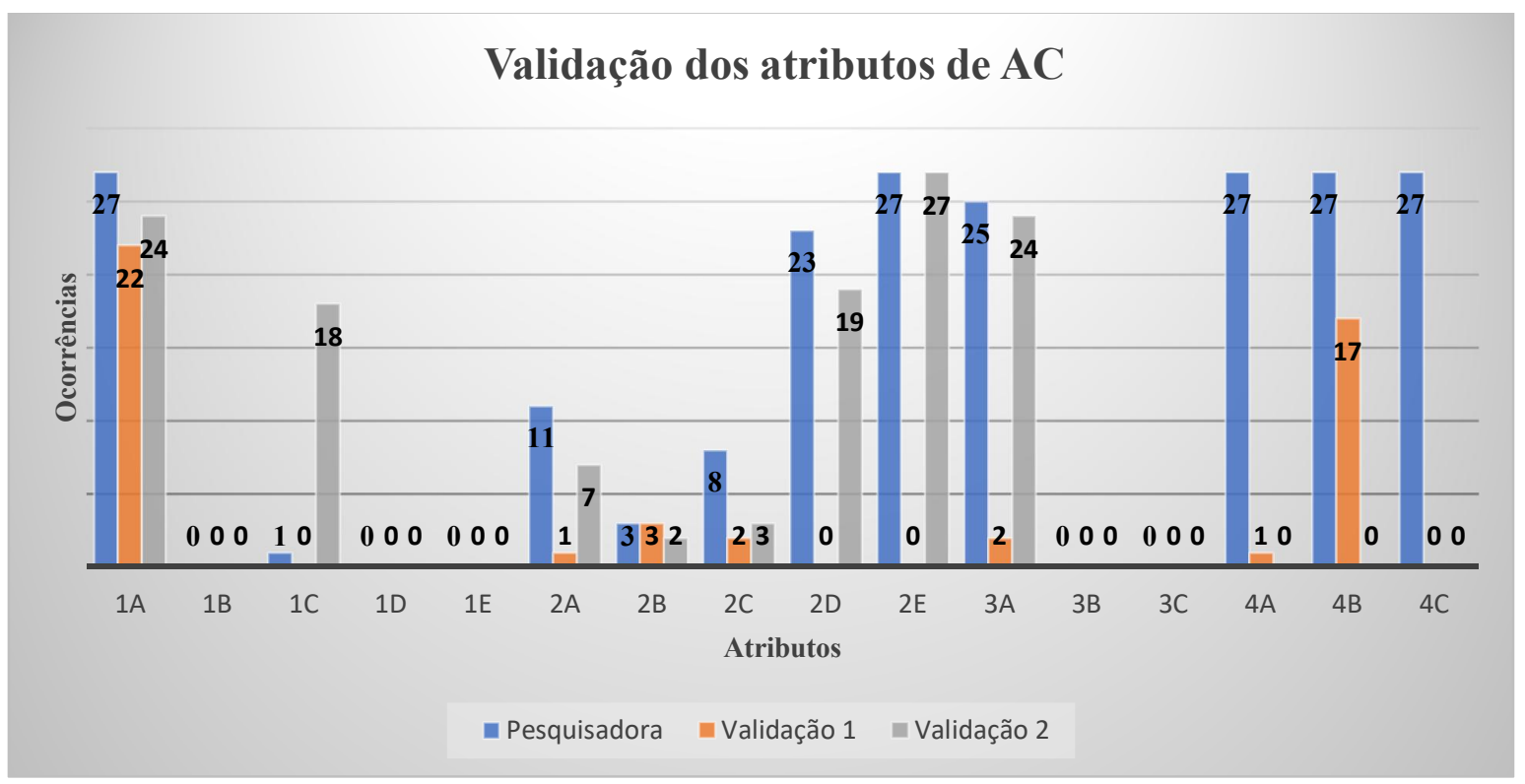




\section{DISCUSSÃO}


Este trabalho teve como objetivos investigar se e como os materiais educativos utilizados nas diversas ações educacionais e culturais realizadas por um zoológico contribuem para o processo de alfabetização científica do público. Para isso analisamos duas dimensões do trabalho com esses materiais: a perspectiva dos idealizadores dos materiais e a interação do público com um dos materiais educativos durante a visita com os materiais produzidos pelo Zôo de Sorocaba.

Para realizar a análise aplicamos os indicadores e os atributos de AC desenvolvidos inicialmente por Cerati (2014) - indicadores científico, institucional, interface social, estético/afetivo. Oliveira (2016) e Rocha (2016) ampliaram e aprofundaram esta ferramenta incluindo referenciais relacionados com a participação e o engajamento do público, que valorizam o diálogo e o protagonismo deste. Assim, este trabalho teve o papel de aplicar e validar a ferramenta teórico-metodológica desenvolvida pelas autoras acima citadas.

Os procedimentos metodológicos de coleta e análise dos dados em conjunto com a ferramenta teórico-metodológica nos permitiu analisar os dados de forma qualitativa e quantitativa. A análise qualitativa centrou-se especialmente no estudo do potencial dos materiais educativos para o processo de AC, a partir das intenções de seus idealizadores. Já a análise quantitativa foi, corroborada pelos dados obtidos de forma qualitativa com base nas entrevistas, documentos e publicações relacionadas aos materiais. Este processo conferiu maior rigor, amplitude e precisão aos dados, fortalecendo e respondendo uma de nossas questões de pesquisa referente a contribuição dos materiais educativos para o processo de AC do público visitante.

Ainda com relação aos aspectos metodológicos, realizamos a validação da análise dos dados sobre o potencial dos materiais educativos para a $\mathrm{AC}$, solicitando que duas pesquisadoras do GEENF, que estão desenvolvendo investigações com base no mesmo referencial teórico deste trabalho, realizassem a categorização dos mesmos com base nos indicadores e atributos utilizados. A validação e a triangulação dos resultados nos permitiram perceber a importância da utilização de metodologias e procedimentos variados de coleta e análise de dados para que o processo de investigação se torne mais completo, com diversos olhares sobre o mesmo problema (ALVES-MAZZOTTI; GEWANDSZNAJDER, 1999). Importante destacar que esta validação por pares não foi feita com os resultados da análise do público.

Os resultados das três validações realizadas a partir da categorização dos materiais educativos com base nos indicadores e atributos de AC não foram rediscutidos com as duas pesquisadoras, o que poderá ser feito posteriormente. Contudo, atribuímos as disparidades de alguns dos 
resultados ao fato das duas pesquisadoras só terem tido acesso à tabela elaborada por nós e que sintetizava as características dos materiais. Diferentemente da análise realizada pela autora deste trabalho, as demais pesquisadoras não tiveram acesso às entrevistas e aos documentos que esclarecem bastante as intenções para a produção dos materiais educativos analisados. Esse fato nos leva a refletir sobre a necessidade de aprimorar o processo de validação, o qual deve incluir o mesmo corpo de dados para todos os pesquisadores que irão realizar a análise e diferentes etapas em que, não somente a ferramenta teórico-metodológica deva ser discutida entre a equipe de validação, mas também os resultados obtidos por cada um, buscando com isso um consenso maior. Com base nas 3 categorizações propostas, procedemos a um ajuste de alguns atributos em função da classificação das outras pesquisadoras.

Partindo da premissa que os museus são espaços com potencial para contribuir para a alfabetização científica da população e sabendo que eles desenvolvem várias atividades para o público que podem ou não serem estruturadas nessa perspectiva, acreditamos que o trabalho com materiais educativos a partir de objetos biológicos, modelos e réplicas, são ferramentas importantes para contribuir para esse processo. Como afirma Hooper-Greenhill (1994), o processo de aprendizagem dos museus é frequentemente focado no objeto, já que este oferece estímulos à medida que é estudado e manuseado. Segundo a autora, o trabalho com os objetos, pautado em experiências concretas, pode estimular a curiosidade e a lembrança de determinado conhecimento. Tunnicliffe (1996) também menciona que as crianças, quando na presença de objetos biológicos, tendem a ter reações afetivas em relação à vida animal e mostram-se preocupadas com a origem do objeto e questionam sobre sua morte, levando a discussões, participações, levantamento de hipóteses e conclusões sobre os materiais e a temática abordada, importantes aspectos da AC. Considerando os aspectos mencionados iremos agora discutir os resultados obtidos nessa pesquisa. Esta discussão será dividida com a mesma estrutura proposta na coleta e na análise de dados, em dois blocos:
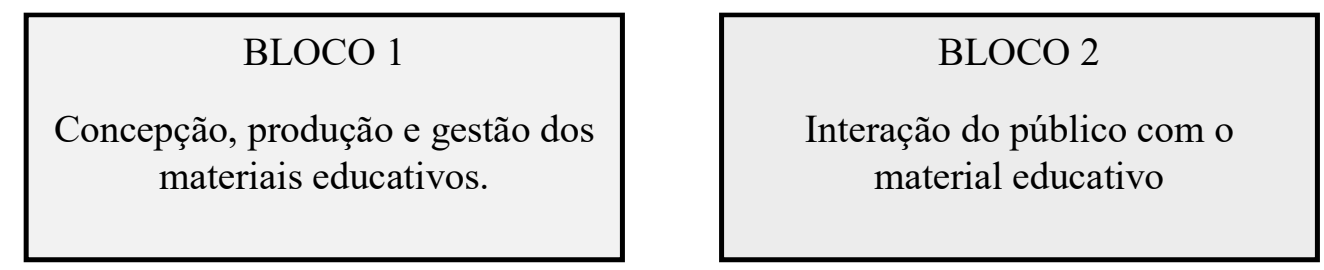


\subsection{CONCEPÇÃO, PRODUÇÃO E GESTÃO DOS MATERIAIS EDUCATIVOS.}

Assumimos desde o início desta pesquisa que os materiais educativos do Zôo de Sorocaba não foram concebidos sob a perspectiva da $\mathrm{AC}$, no entanto como vemos no Quadro 2, que replicamos abaixo para facilitar a visualização, todos os indicadores e vários atributos estão presentes neles. Por outro lado, muitos dos atributos, que julgamos importantes para uma AC mais eficaz, não estão presentes nesses materiais.

Quadro 2: Síntese da ocorrência de indicadores e atributos nos materiais educativos do Zôo de Sorocaba.

\begin{tabular}{|c|c|c|}
\hline INDICADORES & ATRIBUTOS & $\begin{array}{l}\text { OCORRÊNCIA } \\
\text { NOS MATERIAIS }\end{array}$ \\
\hline \multirow{5}{*}{ CIENTÍFICO } & 1a - Conhecimentos e conceitos científicos e suas definições & $\mathrm{X}$ \\
\hline & 1b - Pesquisas científicas & \\
\hline & 1.c - Processo de produção de conhecimento científico & $\mathrm{X}$ \\
\hline & $\begin{array}{l}\text { 1.d - Papel do pesquisador no processo de produção do } \\
\text { conhecimento }\end{array}$ & \\
\hline & 1.e - Dinâmica interna da ciência & \\
\hline \multirow{5}{*}{$\begin{array}{l}\text { INTERFACE } \\
\text { SOCIAL }\end{array}$} & 2.a - Impactos da ciência na sociedade & $\mathrm{X}$ \\
\hline & 2.b - Influência da economia e política na ciência & $\mathrm{X}$ \\
\hline & 2.c - Influência e Participação da sociedade na ciência & $\mathrm{X}$ \\
\hline & 2.d - Identificação dos tipos de público & $\mathrm{X}$ \\
\hline & $\begin{array}{l}\text { 2.e - Ações e produtos de divulgação científica, educação } \\
\text { formal e não formal }\end{array}$ & $\mathrm{X}$ \\
\hline \multirow{3}{*}{ INSTITUCIONAL } & $\begin{array}{l}\text { 3.a - Identificação das instituições envolvidas na produção, } \\
\text { fomento e divulgação da ciência }\end{array}$ & $\mathrm{X}$ \\
\hline & 3.b - Identificação da missão institucional & \\
\hline & $\begin{array}{l}\text { 3.c - Presença de elementos políticos, culturais e sociais } \\
\text { ligados à instituição }\end{array}$ & \\
\hline \multirow{3}{*}{$\begin{array}{c}\text { ESTÉTICO } \\
\text { AFETIVO } \\
\text { COGNITIVO }\end{array}$} & 4.a - Estético e Afetivo & $\mathrm{X}$ \\
\hline & 4.b - Cognitivo & $\mathrm{X}$ \\
\hline & 4.c - Interação física e sensorial & $\mathrm{X}$ \\
\hline
\end{tabular}




\section{Indicador Científico}

Cerati (2014) ressalta que "uma exposição que pretende contribuir para a AC deve expressar a questão da natureza da ciência, fornecendo suporte para que o visitante construa seu conhecimento sobre assuntos científicos" (p. 79). Com base nesta mesma premissa, consideramos que os materiais educativos que pretendam contribuir para a AC do público também devam expressar essas questões.

Constatamos que o atributo "1a - Conhecimentos e conceitos científicos", está presente em todos os materiais analisados. A presença deste atributo vai ao encontro dos objetivos pretendidos pelas idealizadoras dos materiais, conforme apresentado na análise das entrevistas e documentos (Capítulo 5). Entendemos que se o conhecimento dos conceitos é importante para a AC, como indicado por Bybee (1994); Norris e Philips (2003); Roberts (2007); Hurd (1958, 1998); de Pella, O’Hearn e Gale (1966) entre outros, então trabalhar conteúdos científicos é o ponto de partida para uma ação de divulgação científica que objetiva fomentar a AC de seus visitantes (CERATI, 2014). Portanto, entendemos que neste quesito, os materiais cumprem sua função potencial, de contribuir para a $\mathrm{AC}$ dos usuários, pois em diversas ocasiões propõe o trabalho com conceitos de zoologia, conservação, ecologia, saúde, relação ser humano-animal, relação forma-função como pudemos identificar no Quadro 1 do Apêndice E.

O atributo "1b - Pesquisas científicas" está ausente nos materiais, segundo nossa análise, e, a partir das entrevistas, percebemos que não havia a preocupação com esta questão no momento da concepção dos mesmos, apesar das entrevistadas terem demonstrado a importância desse item. Na nossa opinião, a presença deste atributo permitiria que o cidadão desenvolvesse consciência sobre pesquisas que estão sendo realizadas e conhecesse como a ciência é produzida. As entrevistadas e os documentos analisados salientam que as pesquisas do Zôo de Sorocaba geram conhecimento sobre comportamento, reprodução e fisiologia (ZOO SOROCABA, 2015), mas essas questões não estão refletidas nos materiais educativos produzidos pelo Zôo.

Vários autores têm se debruçado sobre as discussões da importância de que o indivíduo conheça as pesquisas científicas em andamento, sejam elas aplicadas ou não, seus processos, resultados, aplicações e inovações, que estão sendo desenvolvidas na atualidade, como defendem Pedretti (2002), Einsiedel e Einsiedel (2004), Delicado (2010) e Hine e Medvecky (2015). A não identificação deste atributo nos leva a considerar que estes materiais não cumprem a função de aproximar a pesquisa do público que o frequenta e têm muito mais a intenção de informar 
conteúdos zoológicos ao público sem a ideia de discutir de onde eles vêm e como são produzidos.

O atributo "1c - Processo de produção da pesquisa científica" apareceu, porém de maneira bastante incipiente nas nossas análises. A presença deste atributo é uma forma de possibilitar o entendimento do procedimento metodológico relacionados às investigações científicas, o que favorece o entendimento de caráter inacabado e coletivo da produção científica, possibilitando uma participação mais aprofundada por parte do indivíduo na tomada de decisões sobre pesquisas que impactam sua vida. Consideramos que em algumas situações isto, potencialmente possa ocorrer, por exemplo, quando o professor leva o material para sua aula, ele pode abordar questões de preparação dos materiais, discutir as técnicas utilizadas para sua conservação e como foram desenvolvidas. Na mochila de curiosidades, aspectos sobre o desenvolvimento de pesquisa poderia ser abordado quando os animais taxidermizados são apresentados ao público: por exemplo o mediador poderia abordar seu modo de preparação e a importância que a pesquisa científica tem nesse processo. A questão da parceria e da construção coletiva de conhecimento científico aparece como uma das realizações da equipe de pesquisadores do Zôo de Sorocaba quando o site afirma que os seus pesquisadores atuam junto ao esforço conservacionista nacional e mundial através de planos de manejo, tanto em cativeiro como na natureza, contudo esta discussão não está explicitada nos materiais. Pesquisadores como KnorrCetina (1981); Castelfranchi (2008); Kuhn (2005); Sismondo (2010) refletiram sobre a relevância de se promover o acesso a dinâmica interna da ciência, aos processos de produção da ciência relacionados à levantamento de hipóteses, realização de testes, processos técnicos, registros, observação entre outros, e estes poderiam ser explorados numa reflexão com os usuários dos materiais e contribuiriam para o processo de $\mathrm{AC}$

Os atributos " $1 \mathrm{~d}$ - Papel do pesquisador no processo de produção" e "le - Dinâmica interna da ciência" não foram identificados nos materiais educativos. A presença destes atributos contribuiria para o conhecimento das várias concepções de ciência, seu caráter coletivo e questionável, além de possibilitar a compreensão das controvérsias internas à sua produção, seu caráter histórico e da não neutralidade do conhecimento científico. Para Fagundes (2013); Castelfranchi (2008) e Greco (2007), atualmente o papel dos cientistas ganhou novas atribuições e importância no sentido de que ele deve ser um comunicador, divulgador dos resultados de seu trabalho e se preocupar com a apropriação dos resultados pelos cidadãos. A dimensão ética e a responsabilidade social dos pesquisadores são características fundamentais que devem ser discutidas para um melhor entendimento no momento que for necessário o 
cidadão optar por políticas ou pela destinação de verbas para pesquisa. Além disso, a não discussão da dinâmica de funcionamento e da ciência como constructo humana, dá a ela uma dimensão "mágica" e faz com que os cientistas sejam vistos como "detentores de habilidades especiais", o que de certa maneira, pode afastar o cidadão comum das discussões sobre pontos que possam interferir em seu cotidiano.

O trabalho de Contier (2009) investigou como as exposições de museus de ciências no Brasil exploram as relações entre ciência, tecnologia e sociedade na perspectiva de contribuir para a formação de cidadãos mais críticos em relação às questões de C\&T. Uma das conclusões do trabalho foi que existe uma dificuldade em identificar exposições que tratem de temáticas como as atribuições dos diferentes membros da equipe de pesquisa, a responsabilidade social do pesquisador, a ciência como um produto da construção humana, entre outros. Percebemos pelos nossos dados, que o mesmo ocorre com os materiais educativos. Os atributos relacionados aos aspectos éticos e de discussões em torno da natureza da ciência e do papel do pesquisador no processo de construção do conhecimento estão ausentes dos materiais.

\section{Indicador Interface Social}

Todos os atributos referentes a este indicador foram identificados durante nossa análise, o que pode significar que esses materiais apresentam um potencial real que proporcione o entendimento do significado social da ciência e expresse aspectos dos impactos da ciência na sociedade, além de assumirem a opção por certos tipos de público. Tais ações podem auxiliar o cidadão a entender temas debatidos na atualidade e o instrumentaliza a tomar decisões sobre assuntos complexos presentes no seu cotidiano (CERATI, 2014).

Muitos autores afirmam que a AC é o conhecimento necessário para o entendimento de questões que possibilitam às pessoas refletirem, compreenderem, emitirem opinião e participarem do debate nacional acerca dos progressos científicos (FOUREZ, 2003; AULER; DELIZOICOV, 2001; NORRIS; PHILIPS, 2003; BYBEE, 1994; SASSERON; CARVALHO, 2008) e nossos resultados indicam que esses materiais podem possibilitar o desenvolvimento de uma consciência participativa mais aprofundada no cidadão que interage com eles, uma das características do indicador interface social. Garcia (2006) menciona que o trabalho educativo no Zôo de Sorocaba tinha a intenção de proporcionar ao público não só informações científicas, mas promover a participação na comunidade em ações voltadas à conservação ambiental. Nossos dados corroboram essa afirmação na medida em que todos os atributos do Indicador Interface Social estão presentes e podem possibilitar o desenvolvimento deste aspecto da AC. 
É relevante destacar que esse indicador aparece intensamente, no caso específico dos materiais do Zôo, em função da temática ambiental. Esta instituição possui como uma de suas missões a promoção da conservação e da educação ambiental e muitas de suas atividades com o público se pautam nessas premissas. Sabemos que o tema ambiental é um bom promotor de interfaces com a sociedade já que mobiliza as pessoas a realizar ações de conservação e de cuidado nos âmbitos individual e coletivo. Dessa forma, podemos afirmar que, no que tange ao indicador interface social, os materiais educativos têm o potencial de proporcionar o diálogo entre a ciência e as questões sociais atuais, especialmente em relação a aspectos de conservação das espécies e seus ambientes, uso racional de recursos naturais, cuidados com a saúde, consumo responsável entre outros. No entanto, a ocorrência mais baixa do atributo $2 b$ (Influência da economia e política na ciência) nos indica que os materiais proporcionam pouca discussão sobre a complexa relação ciência/sociedade, não abordando aspectos relacionados ao financiamento da ciência, por exemplo.

\section{Indicador Institucional}

O único atributo identificado por nós relacionado a este indicador foi o "3.a - Identificação das instituições envolvidas na produção, fomento e divulgação da ciência" no momento em que os guias para os professores presentes nos kits ecológicos trazem a identificação da equipe do Zôo de Sorocaba como autora do material de apoio. Durante as entrevistas, ficou evidente que não houve a preocupação em discutir a questão institucional da ciência nos guias dos kits ecológicos ou na mediação das visitas com o uso do material. Apesar do Zôo de Sorocaba ser reconhecidamente importante na pesquisa de manejo de fauna, comportamento, reprodução e fisiologia não houve menção a elas nos materiais.

A presença maior desse indicador ajudaria o visitante a esclarecer o papel do zoológico e a influência de sua produção científica na sociedade, possibilitando a compreensão da dimensão institucional da ciência. Conforme Cerati (2014), “a importância deste indicador está em facilitar a aproximação do cidadão com a ciência produzida na academia, da qual, muitas vezes, os museus de ciências são integrantes, além de permitir a percepção que a produção social da ciência envolve sua dimensão institucional”' (p. 81).

\section{Indicador Estético/Afetivo/Cognitivo}

Este indicador foi identificado nos 27 materiais analisados com os seus três atributos. Stocklmayer (2002) menciona que quando as pessoas têm oportunidade de participar 
ativamente no processo de aprendizado, interagindo com os objetos e materiais, podem efetivamente entender a ciência e o que ela pode realizar. Segundo Campos (2009), os materiais educativos produzidos pelos museus possuem um grande potencial de estimular a aprendizagem e a participação do público após e durante a visita. Esses aspectos são muito valorizados na educação em espaços não-formais, em especial nas exposições, pois eles buscam promover o engajamento dos visitantes por meio de diversos tipos de interação com os objetos ali presentes (WAGENSBERG, 2000).

O atributo "4a - Estético e Afetivo" foi identificado quando o material apresentou potencial para estimular manifestações de sentimentos como apreço, prazer, repulsa, indignação ou outras sensações. Identificamos este atributo em todos os materiais devido a características como a possibilidade dos animais poderem ser observadas "ao vivo" e de perto, o fato de se apresentarem em escala real e serem autênticos. As entrevistadas mencionaram que durante a idealização dos materiais tiveram a intenção de proporcionar um contato direto e efetivo com os materiais originais conservados e que os usuários manifestaram sensações diversas em muitas oportunidades, por exemplo, uma das entrevistadas nos contou que “... (as crianças) querem ver de perto, poder pegar..." e "Alguns tocam, chegam perto, mas outro nem querem chegar perto". As entrevistadas contaram também que alguns visitantes manifestam um sentimento de repulsa ao se aproximarem dos objetos originais conservados, principalmente em se tratando de partes de animais. Portanto, esses materiais possibilitam o compartilhamento de sensações e têm o potencial de conectar o público com o fato que está sendo observado ou proposto. Segundo Leinhardt e Crowley (2015) essa resposta emocional dos visitantes ao contato com os materiais pode ser um ponto relevante na identificação do usuário com o ambiente de aprendizado e pode possibilitar vivências que ajudam na construção dos conhecimentos científicos.

Tunnicliffe (1999) e Allen (2202) em suas pesquisas nos contam que o trabalho com objetos em museus ou zoológicos apresenta uma variedade de estímulos que podem desencadear novas percepções e que o processo de aprendizagem que ocorre nessas instituições tende a ser afetivo e pessoal. Portanto, os objetos presentes na mochila do Zôo e nos kits ecológicos possuem a intenção, segundo os dados das entrevistas, de que o visitante realize uma apreciação não somente cognitiva, mas também afetiva no contato com os materiais, portanto podemos afirmar que os materiais educativos podem estimular a percepção, a contemplação e a exploração dos sentidos sendo um fator de envolvimento do público com o conceito tratado, contribuindo 
positivamente para a $\mathrm{AC}$, especialmente quando se trata de desencadear sensações afetivas que estimulam a observação e empatia do público com o tema.

O atributo " $4 \mathrm{~b}$ - Cognitivo" também apareceu em todos os materiais educativos segundo nossa análise e foi corroborado pelas entrevistas, documentos e publicações. Pudemos observar que a interação com os kits ecológicos e com a mochila de curiosidade pode ter o potencial de estimular a observação, nomeação, questionamento e possibilitar a formação de opiniões a respeito dos conceitos trabalhados neles. Essas são características importantes para o desenvolvimento da $\mathrm{AC}$ pois sensibiliza e envolve o público possibilitando a aprendizagem por meio de diferentes formas de interações, o que mostra ser uma característica importante para a construção de significados (CERATI, 2014).

$\mathrm{O}$ aspecto motivacional proporcionado pelo contato direto e manipulação dos objetos também contribui para a AC e para a construção do conhecimento do visitante. Falk e Dierking (2000) mencionam que as expectativas e os interesses dos visitantes são aspectos intrínsecos da aprendizagem e os objetos e materiais analisados possuem essas finalidades.

O atributo "4.c - Interação física e sensorial" refere-se aos diversos níveis de interatividade física e sensorial com o objeto e se os materiais possibilitam e estimulam o envolvimento das pessoas, valorizando os conhecimentos prévios do público.

Todos os materiais podem ser manipulados pelo público, esta possibilidade cria também um envolvimento e a possibilidade do surgimento de questões de várias naturezas: conceitual, política, de conservação, de consumo racional, qualidade da água para consumo, poluição entre outros. Além disso, essa interação possibilita o estímulo dos sentidos (visão, audição, olfato e tato) para explorá-los. A partir desse momento, é possível que estímulos sensoriais reais e autênticos sejam despertados, sentimentos sensibilizando o visitante, o que os leva a compartilharem conhecimentos e experiências (GARCIA, 2006; WAGENSBERG, 2001).

Assim, nossos resultados, a partir das observações e pelas entrevistas e documentos analisados, apontam que os 4 indicadores de AC estão presentes nos materiais e 11 atributos $(68,75 \%)$, dos 16 foram identificados.

Entender a ciência e seu processo de construção contribuem para controlar e prever as transformações que ocorrem no ambiente, compreendendo melhor o universo e a natureza, o que poderá levar a uma melhor relação do ser humano com o ambiente que o cerca (KRASILCHIK; MARANDINO, 2004; SABBATINI, 2014; CAVALCANTE, 1999; DEMO, 
2010; CHASSOT, 2003). O processo de AC forma cidadãos mais críticos capazes de compreender e participar de decisões sobre ciência que interfiram em sua vida pessoal e da comunidade a partir do domínio de conceitos e visão crítica sobre a ciência e a tecnologia (CHASSOT, 2003). Neste contexto, os jardins zoológicos são centros de educação não formal e os materiais educativos por eles produzidos estão entre as iniciativas que podem contribuir para o processo de $\mathrm{AC}$ dos cidadãos.

Consideramos que o resultado da análise do potencial dos materiais para a promoção da AC foi bastante significativo, já que a produção e utilização de materiais educativos com o público visitante fazem parte de uma das atividades mais realizadas nos museus (MARANDINO et al, 2016). Apesar de alguns atributos não terem sido identificados por nós nos materiais, mais de $50 \%$ deles foi identificado. Os atributos não identificados nos materiais são aqueles referentes à pesquisa e à instituição, papel do pesquisador e políticas de ciência que não foram citados nas entrevistas e documentos como prioridade da instituição para discussão com o público.

\subsection{INTERAÇÃO DO PÚBLICO COM OS MATERIAIS EDUCATIVOS}

Como indicado anteriormente, para investigar a presença ou ausência dos indicadores e atributos de $\mathrm{AC}$ durante a interação do público com os materiais, foram utilizados os dados de Garcia (2006) durante visita de uma turma de alunos do ensino fundamental I mediada com o material "mochila de curiosidades". A seguir reapresentamos a tabela síntese com os indicadores e atributos encontrados e com aqueles ausentes das SDRs durante as interações entre os objetos da mochila e o público e tecemos comentários sobre os resultados. 
Quadro 4: Síntese da ocorrência de indicadores e atributos comparando o material educativo "mochila de curiosidades" a partir de nossa análise com as interações dos alunos.

\begin{tabular}{|c|c|c|c|}
\hline INDICADORES & ATRIBUTOS & $\begin{array}{l}\text { MOCHILA DE } \\
\text { CURIOSIDADES }\end{array}$ & $\begin{array}{l}\text { INTERAÇÃO } \\
\text { DOS ALUNOS }\end{array}$ \\
\hline \multirow{5}{*}{ CIENTÍFICO } & $\begin{array}{l}\text { 1a - Conhecimentos e conceitos científicos } \\
\text { e suas definições }\end{array}$ & $\mathrm{X}$ & $\mathrm{X}$ \\
\hline & $1 \mathrm{~b}$ - Pesquisas científicas & & \\
\hline & $\begin{array}{l}\text { 1.c - Processo de produção de } \\
\text { conhecimento científico }\end{array}$ & $\mathrm{X}$ & \\
\hline & $\begin{array}{l}\text { 1.d - Papel do pesquisador no processo de } \\
\text { produção do conhecimento }\end{array}$ & & \\
\hline & 1.e - Dinâmica interna da ciência & & \\
\hline \multirow{5}{*}{ INTERFACE SOCIAL } & 2.a - Impactos da ciência na sociedade & $X$ & \\
\hline & $\begin{array}{l}\text { 2.b - Influência da economia e política na } \\
\text { ciência }\end{array}$ & & \\
\hline & $\begin{array}{l}\text { 2.c - Influência e Participação da sociedade } \\
\text { na ciência }\end{array}$ & $\mathrm{X}$ & \\
\hline & 2.d - Identificação dos tipos de público & X & \\
\hline & $\begin{array}{l}\text { 2.e - Ações e produtos de divulgação } \\
\text { científica, educação formal e não formal }\end{array}$ & $X$ & \\
\hline \multirow{3}{*}{ INSTITUCIONAL } & $\begin{array}{l}\text { 3.a - Identificação das instituições } \\
\text { envolvidas na produção, fomento e } \\
\text { divulgação da ciência }\end{array}$ & $\mathrm{X}$ & \\
\hline & 3.b - Identificação da missão institucional & & \\
\hline & $\begin{array}{l}\text { 3.c - Presença de elementos políticos, } \\
\text { culturais e sociais ligados à instituição }\end{array}$ & & \\
\hline \multirow{3}{*}{$\begin{array}{l}\text { ESTÉTICO AFETIVO } \\
\text { COGNITIVO }\end{array}$} & 4.a - Estético e Afetivo & $\mathrm{X}$ & $\mathrm{X}$ \\
\hline & 4.b-Cognitivo & $X$ & $\mathrm{X}$ \\
\hline & 4.c - Interação física e sensorial & $\mathrm{X}$ & $X$ \\
\hline
\end{tabular}

\section{Indicador científico}

Durante as interações identificamos este indicador em 17 SDRs das 19 analisadas, corroborando com os dados das entrevistas e documentos analisados que destacaram a importância de trabalhos com os conceitos científicos durante a idealização do material. Este resultado nos indica que este material não somente cumpre sua função no que tange a tratar conceitos durante a mediação, como também promove essa dimensão da AC. Muitos autores, entre eles Norris e 
Philips (2003); Roberts (2007); Hurd (1998) e Cerati (2014) defendem que a compreensão de conteúdos científicos é de extrema relevância para o processo de $\mathrm{AC}$ dos indivíduos.

O atributo "la - Conhecimentos e conceitos científicos e suas definições" foi identificado em 17 SDRs durante a interação. Percebemos que após serem estimuladas pelo mediador, as crianças observavam o material dialogando entre si e com ele. Os principais temas dos diálogos se referiam à identificação dos animais, características morfológicas relacionadas à função, biologia dos animais ligada ao modo de vida, alimentação, reprodução, locomoção e comportamento. Verifica-se, desse modo, que a interação com os objetos do material contribui com o processo de apropriação de conceitos científicos. O contato, a interação e o estímulo despertados pelos materiais são importantes para incentivar o público a procurar novas informações, como afirmam Hazen e Trefil (1997), que consideram que a ciência que deve chegar ao público deve trazer um conhecimento mais generalizado. A presença deste atributo durante as interações reflete a intenção dos idealizadores do material que era "ensinar conceitos", como afirmou a entrevistada 3.

Garcia (2006, p.13) afirma, durante sua experiência como estagiária do Zôo de Sorocaba, "que é evidente a atração do público por esses objetos, seja pela oportunidade de chegar muito próximo do animal ou pela curiosidade de conhecer suas características in loco" e que as principais questões levantadas pelos usuários da mochila estão relacionadas à morfologia, biologia e comportamento do animal. A autora também concluiu que

"A taxonomia serve de base para a aprendizagem com objetos biológicos, sendo importante para desencadear um diálogo entre crianças e adultos. Percebemos que as crianças utilizam características morfológicas dos objetos, em uma linguagem do seu cotidiano, para identificá-los, ... caracterizá-los, e que, no decorrer da mediação, elas têm a oportunidade de ampliar o seu vocabulário, incorporando conceitos da ciência, os quais podem ser construídos e não apenas instruídos" (GARCIA, 2006, p.148).

$\mathrm{Na}$ nossa análise das SDRs percebemos que o principal aspecto relacionado aos conceitos trabalhados foi a identificação do animal e de suas características de maneira isolada do ambiente e do processo evolutivo, não abordando essa dimensão para explicar o desenvolvimento da forma e do comportamento dos grupos animais. Talvez essa questão não tenha sido abordada na formação para a mediação com o material pela equipe do Zôo de Sorocaba e, portanto, não foi abordada pelo mediador nesta experiência. A discussão destes aspectos poderia enriquecer a construção de conhecimentos relacionados ao papel do ambiente 
na biologia dos organismos e contribuir nos debates sobre conservação, como é o objetivo dos educadores do Zôo de Sorocaba. Podemos inferir que os conceitos abordados e apropriados pelos alunos, estão muito ligados ao que o mediador trata durante a interação com os objetos da mochila do que com a intenção das idealizadoras do material, ressaltando assim o papel deste profissional no trabalho de atendimento ao público nos museus. A abordagem evolutiva foi por nós destacada, pois percebe-se que este aspecto é pouco explorado em exposições e ações educativas nos museus, incluindo os zoológicos, onde muitas vezes se reforça a perspectiva da taxonomia lineana nomenclatural não abordando as relações de parentesco entre os espécimes. Os zoológicos, a nosso ver, devem refletir sobre este aspecto e promover mais ações nessa direção.

Os atributos "1b - Pesquisas científicas", "1c - Processo de produção de conhecimento científico", "1d - Papel do pesquisador no processo de produção do conhecimento" e "1e Dinâmica interna da ciência" não foram identificados por nós durante a interação. Isto confirma que resultados de pesquisas, avanço das pesquisas em andamento no Zôo de Sorocaba ou pesquisas globais sobre conceitos e temáticas que, potencialmente poderiam ser discutidas e levantadas pelo mediador, não eram prioridade e não foram levadas em consideração pela equipe no momento de discutir o uso do material com o público. Segundo Hurd (1998) entender o papel do pesquisador e o produto do conhecimento científico aplicado na sociedade é uma das habilidades que uma pessoa alfabetizada cientificamente deve possuir. Percebemos, portanto, que neste requisito, os materiais deixaram a desejar no que se refere a promoção da $\mathrm{AC}$, pois não trataram em nenhum momento do tema e nem houve a intenção durante sua concepção ou formação do mediador.

\section{Indicador interface social}

O indicador Interface social não foi identificado por nós nas SDRs analisadas. Interpretamos que o atributo referente ao impacto da ciência na sociedade, poderia ter sido explorado pelo mediador, por exemplo, nos momentos em que há a interação com o crânio da onça pintada com um tiro e com o crânio de tamanduá-bandeira, animais sabidamente ameaçados de extinção pela destruição de seus habitats. Cerati (2014), Hanzel e Trefil (1997) e Shen (1975) são alguns dos autores que mencionam que ações que contemplam discussões relacionadas ao impacto da ciência na sociedade instrumentaliza os indivíduos para tomada de decisão e trata-se de um conhecimento importante para o entendimento de temas públicos que possibilitam às pessoas refletirem, compreenderem, emitirem opinião e participarem do debate nacional acerca desses 
impactos na sua vida. As questões ambientais, nesses casos, poderiam ser ótimas pontes para que os atributos deste indicador se fizessem presentes.

Garcia (2006), destaca, na discussão de seu trabalho, a ausência, na mediação das visitas ao Zôo, de uma perspectiva crítica da educação ambiental. Com base em Reigota (2001), a autora comenta que a seleção dos conteúdos a serem trabalhados na educação ambiental dependerá do contexto a ser trabalhado e, muitas vezes, esses são focados nas espécies vegetais e animais e nas suas interdependências e na extinção das espécies. Reigota indica que, muitas vezes, as atividades oferecidas nesses locais se baseiam somente na transmissão de conhecimentos científicos e na conscientização para a conservação da natureza, deixando de abordar os aspectos políticos, sociais e culturais, o que leva as atividades educativas desses espaços a serem consideradas apenas ensino de biologia e/ou ecologia e não de educação ambiental.

Entendemos que a perspectiva da educação ambiental crítica indicada se aproxima da proposta de AC que busca discutir as dimensões políticas e sociais da ciência. Neste sentido, o trabalho com a "mochila de curiosidades" tem potencial para desencadear discussões sobre questões polêmicas sobre ciência como as citadas acima, se houver um interesse ou preocupação da equipe no momento da formação do mediador especialmente em relação a questão da destruição dos ambientes naturais que constatamos atualmente, e que foi enfatizado diversas vezes pelas entrevistas, como um dos principais objetivos dos materiais educativos do Zôo de Sorocaba.

Vemos assim, que para que esses aspectos da $\mathrm{AC}$ sejam tratados junto ao público, o papel do mediador é fundamental. Como aponta Garcia

\footnotetext{
"Consideramos que a transmissão de conceitos científicos relacionados à biologia e à ecologia são necessários para a compreensão de alguns temas dessas áreas (ecossistema, habitat, cadeia alimentar, entre outros) e para estabelecer ligações entre a ciência e as questões ambientais imediatas (locais e globais), ficando a cargo do mediador a condução dessa ação" (GARCIA, 2006, p.168).
}

\section{Indicador Institucional}

Este indicador não foi encontrado nas interações dos alunos com o material. As falas das entrevistadas corroboram nosso resultado no sentido de que as discussões sobre a ciência como instituição, materializada em locais de pesquisa e divulgação como museus e zoológicos, sobre a produção científica do Zôo de Sorocaba, sobre o trabalho dos pesquisadores deste local, sobre 
as atividades relacionadas à preparação e conservação dos materiais para pesquisa e divulgação não estavam presentes na concepção dos materiais e consequentemente não estiveram presente durante a formação dos mediadores e sua intervenção com as crianças. A presença deste indicador auxiliaria as crianças a se aproximarem mais da produção da ciência e compreender o papel do cidadão em decisões de pesquisa que muitas vezes influenciam sua própria vida, como mencionado por Cerati (2014), Krasilchik (2009) e Marandino (2001). Na verdade, aspectos do indicador institucional poderiam ser discutidos com as crianças durante a mediação, no entanto, para isso a instituição deve assumir sua intenção de trabalhar com essa dimensão da $\mathrm{AC}$ em suas ações.

\section{Indicador Estético/afetivo/cognitivo}

Identificamos este indicador em todas as SDRs. O indicador estético-afetivo-cognitivo está relacionado à ação que tem potencial de despertar dimensões relacionadas à afetividade, interação, percepção, motivação e aprendizagem. Este resultado está de acordo com os resultados obtidos na análise do potencial dos materiais, apoiado pelas entrevistas e documentos analisados pois todos eles se referem a intenção de estimular e chamar atenção sobre as temáticas tratadas no Zôo de Sorocaba utilizando-se da interação física, emocional e cognitiva com os materiais.

Identificamos a presença do atributo "4a - Estético e Afetivo" nas 19 SDRs analisadas. Este atributo pode ser identificado quando a interação desperta o potencial para estimular manifestações de sentimentos como apreço, prazer, repulsa, indignação ou outras sensações como pudemos observar durante os diálogos das crianças interagindo com os objetos da mochila. Interpretamos que a interação com os objetos pode também estimular a contemplação e consequentemente o envolvimento com o tema tratado possibilitando a aprendizagem e contribuindo para a AC (FALK; DIERKING, 1992; PEDRETTI, 2004).

Mergulhão (2002), investigou os animais com os quais as pessoas têm menos afinidade (cobra, sapo, onça, aranha, rato, barata, entre outros) e verificou que uma das possíveis origens das sensações e dos sentimentos negativos para com esses animais está relacionado com as informações adquiridas. Esses dados reforçaram a importância que o contato com os animais da "mochila de curiosidades" tem para promover a aproximação do público com esses animais e facilitar a aquisição de informações científicas sobre eles. Além disso, desenvolver sentimentos positivos em relação a eles para que esses não desencadeiem ações que possam comprometer os animais e seus ambientes. 
Consideramos também, que o fascínio causado pelos animais aos humanos e que a curiosidade parecem ser um pressuposto essencial para a apropriação de conhecimentos, logo as exposições e outras atividades que proporcionam o contato com animais podem contribuir como um importante elemento nos processos de alfabetização científica permitindo ao visitante vivenciar experiências significativas e agregar conceitos de diversas áreas de conhecimento.

O atributo " $4 \mathrm{~b}$ - Cognitivo" pressupõe a possibilidade de promover habilidades relacionadas aos processos de investigação científica e operações como observação, nomeação, afirmação, comparação, caracterização, suposição, explicação, questionamento, emissão de opinião, conclusão e generalização, a partir da interação com o objeto. Identificamos a presença de muitas dessas características na interação das crianças com os objetos da mochila no momento em que identificam os animais, os nomeiam e discutem algumas questões com o mediador emitindo opiniões sobre o tema específico tratado.

O atributo "4c - Interação física e sensorial” também foi identificado em todas as SDRs. Esse atributo considera os diversos níveis de interatividade física e sensorial com o objeto (WAGENSBERG, 2001), se a ação possibilita e estimula a relação entre os alunos e se há valorização dos conhecimentos prévios deles.

Tunnicliffe (1996) menciona que o contato com os animais preservados da mochila estimula questões relacionadas à identificação, preparação e conservação do animal, autenticidade do objeto e características do corpo. Estes aspectos podem ser complementados, no caso dos zoológicos, com a observação do animal vivo, que despertaria, segunda a autora, aspectos ligados ao comportamento e ao modo de vida do organismo. Os dados dos diálogos das crianças durante as interações com os animais da mochila corroboram essa afirmação, pois observamos em diversas oportunidades as crianças fazendo a identificação e nomeando os animais. Os dados também nos mostraram que o contato com os objetos conservados suscitou questões referentes ao modo de conservação e manutenção desses animais em algumas oportunidades.

Como na análise do potencial dos materiais educativos do Zôo, nem todos os indicadores e atributos foram identificados por nós durante as interações dos objetos da mochila com o público. No entanto, alguns indicadores e atributos importantes para a $\mathrm{AC}$ estão presentes na utilização deste material.

Analisando os diálogos dos alunos com o mediador durante a interação com a mochila identificamos a presença de 2 dos 4 indicadores existentes - Científico e 
Estético/afetivo/cognitivo. Estes indicadores assumem uma importância significativa se analisarmos sua contribuição para a AC do público: conceitos científicos foram abordados e discutidos com os alunos; a discussão sobre questões da relação da morfologia com o ambiente e o modo de vida dos animais; a interação física, afetiva e cognitiva com os objetos da mochila possibilita um aumento de interesse, motivação e atenção em relação aos assuntos que a equipe de educação ambiental do Zôo de Sorocaba tinha intenção de discutir com o usuário do material.

A ausência do indicador interface social durante a interação nos indica que as questões de conservação do ambiente, perda de biodiversidade, uso do ambiente pelo ser humano, disseminação de doenças, consumo responsável entre outros assuntos polêmicos relacionados à destruição do ambiente não foram bem discutidos no uso deste material com o público e, portanto, não houve uma reflexão sobre os impactos no ambiente, como era objetivo dos idealizadores do material. O material tem o potencial de permitir estas discussões mas acreditamos que não houve uma formação adequada do mediador para realizar essa tarefa.

O indicador institucional não foi identificado durante a interação pois dependia muito do tipo de mediação planejada e dos objetivos na concepção dos materiais, que, como vimos nos capítulos anteriores, não foram priorizados. Segundo Marandino (2001) e Achiam e Marandino (2013), ao analisarem exposições de museus, a política adotada pela instituição tem o poder de decisão sobre a abordagem do discurso expositivo, para além de componentes científicos. $\mathrm{Na}$ nossa opinião, portanto, a falta deste indicador diminui a possibilidade do público discutir a questão da importância e do papel da instituição na pesquisa e eventualmente participar de decisões relacionadas a elas. Além disso, discutir ou pelo menos apresentar a instituição que produziu os materiais, permite maior aproximação do público com a ciência produzida na academia e permitir a percepção que a produção social da ciência envolve sua dimensão institucional (CERATI, 2014), o que não parece ser uma prioridade do Zôo de Sorocaba. 
6. CONCLUSÕES 
Este capítulo apresenta as conclusões de nossa investigação em relação à contribuição dos materiais educativos produzidos pelos zoológicos para a alfabetização científica do visitante. Apresentamos também algumas observações sobre a ferramenta teórico-metodológica utilizada para análise da $\mathrm{AC}$ tanto dos materiais como da interação do público com os mesmos.

A literatura na qual nos fundamentamos argumenta que as visitas à zoológicos contribuem em alguns importantes aspectos do processo de AC do cidadão pois, estes locais desenvolvem atividades voltadas à diferentes públicos, que possibilitam discussões de conceitos científicos, debate de ideias relacionadas aos animais e sua conservação, discussões sobre o impacto das pesquisas científicas na vida do indivíduo e da comunidade. Além disso, possuem potencial para a ampliação da cultura científica e inegável papel comunicacional e educativo. Todos estes aspectos são importantes para formar cidadãos mais ativos e conscientes para intervenção na sociedade.

No caso específico dos materiais educativos produzidos pelos zoológicos, os resultados deste trabalho apontam para a importante contribuição que estes espaços podem dar no processo de $\mathrm{AC}$, por meio das atividades desenvolvidas que têm como objetivos aproximar o público da ciência, divulgar conceitos científicos e discutir temas conectados com o cotidiano do cidadão, especialmente ligados à conservação do meio ambiente.

Diante das características do Brasil, com elevada diversidade biológica e elevado grau de ameaça em todos os biomas brasileiros, é fundamental que os materiais educativos e as outras atividades desenvolvidas em locais como zoológicos, que proporcionam o contato com espécies ameaçadas, incentivem abordagens da biodiversidade integradas a um contexto conservacionista reconhecendo e valorizando a diversidade de saberes e de possibilidades de engajamento para a conservação da biodiversidade.

A alfabetização científica pode e deve ser almejada nas ações de zoológicos e outros espaços de divulgação científica, sendo recomendável o incentivo e a valorização de ações educativas que considerem, em seu planejamento, os indicadores de alfabetização científica e seus atributos, uma vez que expressam elementos fundamentais deste processo, tais como conceitos e definições sobre ciência; resultados da pesquisa; processos de produção do conhecimento; relações entre ciência e sociedade; legitimidade de outros saberes; impactos da ciência na sociedade; temas controversos; aspectos relacionados à sensibilização, interação, percepção e motivação do público, gerando envolvimento e ampliando as possibilidades de diálogo, conexão e aprendizagem. 
Os Indicadores Científico, Interface Social e Estético/Afetivo/Cognitivo, foram identificados em $100 \%$ dos materiais analisados. O Indicador Institucional, esteve presente em 25 dos 27 materiais estudados (93\%). A presença desses indicadores para o conjunto dos materiais analisados sugere o potencial que eles possuem para o processo de alfabetização científica de seus públicos. Os materiais educativos analisados, apresentaram 11 dos 16 atributos de AC utilizados na análise $(68,75 \%)$. Consideramos então, que mesmo que esses materiais não tenham sido produzidos na perspectiva da $\mathrm{AC}$, apresentam características importantes que contribuem para este processo no sentido de que aproximam o público do material e permitem que ele reflita, opine e desenvolva conceitos científicos que podem permitir o exercício crítico da cidadania. Contudo, também percebemos que este potencial pode ser ampliado se determinados atributos forem mais explorados nos materiais.

Os atributos do Indicador Científico -"Pesquisas científicas", "Papel do pesquisador no processo de produção do conhecimento" e do Indicador Institucional - "Identificação das instituições envolvidas na produção e fomento a ciência" e "Identificação da missão institucional" não foram identificados durante nossa análise, o que nos faz concluir que os materiais analisados não possuem o potencial para desencadear reflexões e discussões sobre estes aspectos da AC. Essas porém, podem ser melhor exploradas por meio dos manuais que acompanham os materiais ou mesmo introduzindo novos objetos nos kits que estejam relacionados à esses aspectos da $\mathrm{AC}$.

Com relação as interações com o público com um dos materiais que foi analisado por nós, 2 indicadores estiveram presentes (Científico e Estético, afetivo, cognitivo) e dois ausentes (Interface social e Institucional). Nas SDRs das interações das crianças com os objetos da mochila de curiosidades, identificamos 4 dos 16 atributos de AC, isto corresponde a $25 \%$ destes. Notamos a ênfase nos atributos relacionados a conceitos científicos que apareceram em 17 SDRs. Esses dados apontam que a mochila de curiosidades privilegiou, na interação com o público, aspectos conceituais da $\mathrm{AC}$, ficando as dimensões processuais, históricas e da relação da ciência com a sociedade ausentes ou muito pouco presentes.

Consideramos que a mediação poderia ser um momento onde esses aspectos importantes da AC se fizessem presentes. As questões institucionais e controversas podem fazer parte do discurso de mediação que se revela durante a interação do mediador com o público, mesmo quando ausentes nos materiais. Acreditamos que isto não ocorreu, pois, a intenção dos idealizadores dos materiais não era essa e a formação dos mediadores não tinha essa perspectiva. 
Importante dizer que do ponto de vista das ações educativas oferecidas pelos museus em geral e, em particular, os zoológicos, não se defende aqui que cada uma das inciativas deva contemplar todos os aspectos da AC de uma só vez. Seria desejável que o visitante pudesse vivenciar diferentes experiências educacionais nesses espaços, em momentos também diversos de sua vida, se aproximando de forma contínua das várias dimensões da $\mathrm{AC}$ por meio dessas vivências. Sabemos, contudo que na realidade brasileira, a visita a esses espaços ainda se dá de forma pontual na vida dos visitantes. Cabe assim aos educadores dos museus avaliarem a realidade de visitação de sua instituição e refletirem sobre que aspectos da AC são importantes de serem privilegiados nas várias ações, incluindo entre elas os materiais educativos produzidos.

A nosso ver, a utilização da metodologia qualitativa e quantitativa para coleta e análise de dados sobre o potencial dos materiais mostrou-se bastante adequada, pois permitiu que diversos aspectos e ângulos das intenções de produção dos materiais fossem abordados. Além disso, permitiu um olhar mais aprofundado e a identificação dos indicadores e atributos de AC de maneira mais consistente. A adoção de procedimentos para maximizar a credibilidade e confiabilidade da pesquisa, como por exemplo, validação de uma das etapas de análise de dados por pares, a checagem das entrevistas pelas entrevistadas e a triangulação forneceu maior confiabilidade durante a análise dos dados, pois várias visões foram acrescentadas a elas. No entanto, como apontado, é necessário ampliar e desenvolver melhor as etapas de validação por pares, ajustando melhor os procedimentos de categorização.

A ferramenta teórico-metodológica formada por indicadores e atributos vêm sendo desenvolvida e aperfeiçoada no âmbito das pesquisas do GEENF para buscar indícios da ocorrência do processo de alfabetização científica em exposições, atividades educativas, materiais didáticos, documentos e o público nos espaços não formais de educação. Consideramos que esta ferramenta, no nosso caso de pesquisa, foi bastante eficiente em se tratando do bloco que avaliou a concepção, produção e gestão dos materiais educativos, pois foram utilizados procedimentos diversificados para coleta que permitiu uma visão múltipla do problema. No bloco que avaliou a interação dos usuários com a mochila de curiosidades algumas dúvidas no momento da análise nos levam a propor que devemos definir mais claramente dois atributos do Indicador Interface social: 2d. Identificação do público alvo e 2e. Ações e produtos de divulgação científica, educação formal e não formal e como eles se aplicam na análise do público que utiliza os materiais. 
Entendemos que a ferramenta utilizada poderá contribuir na produção de materiais de divulgação em espaço de educação não formal, para que estes sejam concebidos e produzidos na perspectiva da alfabetização científica. Se considerarmos que este processo possibilita fortemente a formação de um cidadão crítico, participante e transformador da sociedade complexa em que vive, os museus, em especial os zoológicos, por meio de seus materiais educativos, podem contribuir em muito para este processo! 
ACHIAM, M.; MARANDINO, M. A framework for understanding the conditions of Science representation and dissemination in museums. Museum Management and Curatorship. vol. 29, n. 1, p. 66-82, 2013.

AIKENHEAD, G. Collective decision making in the social context of science. Science education. v.69, n. 4, 1985.

AIKENHEAD, G. What is STS Science Teaching? In: SOLOMON J.; AIKENHEAD G. STS Education: International Perspectives on Reform. Nova York: Teachers College Press, 1994.

ALBERTI, S. J. J. M. Objetcts and the museum. ISIS, v. 96, p. 559-571, 2005.

ALLEN, S. Looking for Learning in Visitor Talk: A Methodological Exploration. In: LEIHARDT, G. CROWLEY, K, KNUTSON, K. Learning Conversations in Museums. New Jersey: LEA Publishers, p. 259-301, 2002.

ALLUM, N.; BAUER, M. W.; MILLER, S. What can we learn from 25-years of PUS research? Liberating and expanding the agenda. Public Understanding of Science. v. 16, p. 79-95, 2007.

ALVES-MAZZOTTI, A.J.; GEWANDSZNAJDER, F. O Método nas Ciências Naturais e Socais: Pesquisa quantitativa e qualitativa. São Paulo: Pioneira, p.203, 1999.

AMODIO, L. Are museums place where Science and Society can really engage in a dialogue? A positive example related to the rubbish emergency in Campania region. Journal of Science Communications. vol. 7, n. 1, p. 1-3, 2008.

ASH, D. Dialogic Inquiry in Life Science Conservations of Family Groups in a museum. Journal of Research in Science Teaching. v. 40, n. 2, p. 138-162, 2003.

ASSOCIAÇÃO BRASILEIRA DE CENTROS E MUSEUS DE CIÊNCIA; CASA DA CIÊNCIA; MUSEU DA VIDA. Centros e Museus de Ciência do Brasil - 2009. Rio de Janeiro: ABCMC, 2009.

AULER, D. Interações entre ciência-tecnologia-sociedade no contexto da formação de professores de ciências. Tese (Doutorado em Educação: Ensino de Ciências) - Universidade Federal de Santa Catarina, Florianópolis, 2002.

AULER, D. Alfabetização científico-tecnológica: um novo "paradigma"? Pesquisa em Educação em Ciências. v. 5, n. 1, 2003.

AULER, D., BAZZO, W. A., Reflexões para Implementação do Movimento CTS no contexto educacional Brasileiro. Ciência \& Educação. v.7, n.1, p. 1-13, 2001.

AULER, D.; DELIZOICOV, D. Alfabetização científico-tecnológica para quê? Pesquisa em Educação em Ciência. v.3, n.1, p. 1-13, 2001.

AURICCHIO, A. L. R. Potencial da Educação Ambiental nos Zoológicos Brasileiros. Publicação avulsa do Instituto Pau Brasil de História Natural. São Paulo. n. 1, p. 1-46, 1999.

AZEVEDO, C. F. E.; OLIVEIRA, L. G. L.; GONZALEZ, R. K. A estratégia de triangulação: objetivos, possibilidades, limitações e proximidades com o pragmatismo. In: ENCONTRO DE 
ENSINO E PESQUISA EM ADMINISTRAÇÃO E CONTABILIDADE/EnEPQ, 4., 2013. Brasília, Anais... Brasília, 2013. p.1-16, 2013.

BAZARRA, L. Los Zoológicos em camino hacia la educacion: Manual para el educador. México: Subsecretaria de Servicios Educativos para el Distrito Federal, 1994.

BELEI, R. A.; GIMENIZ-PASCHOAL, S. R.; NASCIMENTO, E. N.; MATSUMOTO, P. H. V. R. O uso de entrevista, observação e videogravação em pesquisa qualitativa. Cadernos de educação, FAE/PPGE/UFPEL, v. 30, p. 187-199, 2008.

BELlinASSI, S.; MERGULHÃO, M.C. Confecção e avaliação de kits ecológicos como subsídio didático para professores. Revista Eletrônica do Mestrado em Educação Ambiental, v.17, p. 1517-1256, 2006.

BIZERRA, A. Atividade de aprendizagem em museus de ciências. Tese (Doutorado em Educação) - Faculdade de Educação, Universidade de São Paulo, São Paulo, 2009.

BOGDAN, R.; BIKLEN, S. Investigação Qualitativa em Educação, uma introdução à teoria e aos métodos. Portugal: Porto Editora, 1991.

BONI, V.; QUARESMA, S. J. Aprendendo a entrevistar: como fazer entrevistas em Ciências Sociais. Revista Brasileira dos Pós-Graduandos em Sociologia Política da UFSC, v. 2, n. 3 , p. $68-80,2005$.

BOTAS, D; MOREIRA, D. A utilização dos materiais didáticos nas aulas de matemática - um estudo do $1^{\mathrm{o}}$ ciclo. Revista Portuguesa de Educação, v. 26, n. 1, p. 253-286, 2013.

BRAUNSTEIN, G. K.; SPADONI, M. S.; FARIAS, M. E. Kit didático "Vertebrados Fósseis do Rio Grande do Sul”: relevância e uso no ensino. In: ENCONTRO NACIONAL DE PESQUISA EM EDUCAÇÃO EM CIÊNCIAS (ENPEC), 9, Águas de Lindóia, SP. Atas... Águas de Lindóia, SP, 2013.

BRITO, A. G. O Jardim Zoológico enquanto espaço não formal para promoção do desenvolvimento de etapas do raciocínio científico. Dissertação (Mestrado), Programa de Pós-Graduação em Ensino de Ciências, Universidade de Brasília, 2012.

BUCCHI, M. Science in Society. An introduction to social studies of science, London; New York, N.Y.: Routledge, 2004.

BUCCHI, M. Changing contexts for science and society interaction. In: WEHLING, P.; VIEHÖVER, W.; KPENEN, S. The Public Shaping of Medical Research, London: Routledge, p. 211- 225, 2015.

BUCCHI, M.; NERESINI, B. Science communication over 50 years: patterns and trends. In: SCHIELE, B.; LE MAREC, J.; BARANGER, P. (Eds.). Science Communication Today, Nancy: Editions Universitaires de Lorraine, p. 15-28, 2015.

BYBEE, R. W. Achieving Scientific Literacy. The Science Teacher, v. 62, n. 7, p. 28-33, 1995.

BYBEE, R. W.; DEBOER, G. E. Research on Goals for the Science Curriculum, In: GABEL, D. L. Handbook of research in science teaching and learning. New York: McMillan, 1994. 
CAMARGO, E. O Conceito de Pesquisa Documental. Disponível em: http://pesquisadocumental.blogspot.com.br/p/o-conceito-de-pesquisa-documental.html. Acessado dia: 17 de julho de 2015.

CAMPOS, N. F. Análise das dimensões da biodiversidade presentes em materiais didáticoculturais produzidos e/ou utilizados pelos museus de ciências. São Paulo: Faculdade de Educação da Universidade de São Paulo, 2009. (Relatório de Iniciação Científica).

CAMPOS, N. F. Percepção e Aprendizagem no Museu de Zoologia: uma análise das conversas dos visitantes. Dissertação (Mestrado) - Interunidades em Ensino de Ciências da USP, São Paulo. 2013.

CAMPOS, N. F.; MARANDINO, M. Biodiversidade e suas abordagens em materiais produzidos por um museu zoobotânico - o Museu Paraense Emílio Goeldi. Revista da SBEnBio, n. 3, p. 2613-2621, 2010.

CÂNDIDO, M. M. D. Kits didáticos do Museu da Imagem e do Som do Ceará. Disponível em https://www.academia.edu/2635293/2008_-

Kits_did\%C3\%A1ticos_do_Museu_da_Imagem_e_do_Som_do_Cear\%C3\%A1. Acessado dia: 15 de dezembro de 2016.

CARNEIRO, C. G. Ações educacionais no contexto da arqueologia preventiva: uma proposta para a Amazônia. Tese (Doutorado). Museu de Arqueologia e Etnologia da Universidade de São Paulo, 2009.

CARVALHO, C. Quando a escola vai ao museu. Campinas, SP: Papirus Editora, 2016.

CASCANTE, L. G. Valija didáctica Museo Arqueológico Regional Altos de Chavón. Disponível em: http://altosdechavon.museum/sp_oferta_educativa_main.html. Acessado dia: 10 de junho de 2015.

CASTELFRANCHI, Y. As serpentes e o bastão: tecnociência, neoliberalismo e inexorabilidade. Tese (Doutorado em Sociologia). Instituto de Filosofia e Ciências Humanas, Universidade Estadual de Campinas. Campinas, 2008.

CASTELFRANCHI, Y.; MASSARANI L.; RAMALHO, M. War, anxiety, optimism and triumph: a study on science in the main Brazilian TV news. Journal of Science Communication, v. 13, n.3, p. A 1A-23, 2014.

CAVAlCANTE, M. A. O Ensino de uma Nova Física e o Exercício da Cidadania. Revista Brasileira de Ensino de Física, v. 21, n. 4, p. 550-551, 1999.

CAZELLI, S. Alfabetização Científica e os Museus de Ciência. Dissertação (Mestrado) Departamento de Educação da PUC/RJ - Rio de Janeiro. 1992.

CAZELLI, S.; FRANCO, C. Alfabetismo científico: novos desafios no contexto da globalização. Ensaio - Pesquisa em educação em ciências, v.3, n.2, p. 1-18, 2001. 
CENTRO DE EDUCAÇÃO AMBIENTAL DO PARQUE ZOOLÓGICO MUNICIPAL QUINZINHO DE BARROS. Relatório anual. Sorocaba, SP, 1993/1996.

CENTRO DE EDUCAÇÃO AMBIENTAL DO PARQUE ZOOLÓGICO MUNICIPAL QUINZINHO DE BARROS. Relatório anual. Sorocaba, SP, 1997.

CENTRO DE EDUCAÇÃO AMBIENTAL DO PARQUE ZOOLÓGICO MUNICIPAL QUINZINHO DE BARROS. Relatório anual. Sorocaba, SP, 1999.

CENTRO DE EDUCAÇÃO AMBIENTAL DO PARQUE ZOOLÓGICO MUNICIPAL QUINZINHO DE BARROS. Relatório anual. Sorocaba, SP, 2001/2002.

CENTRO DE EDUCAÇÃO AMBIENTAL DO PARQUE ZOOLÓGICO MUNICIPAL QUINZINHO DE BARROS. Relatório anual. Sorocaba, SP, 2003.

CENTRO DE EDUCAÇÃO AMBIENTAL DO PARQUE ZOOLÓGICO MUNICIPAL QUINZINHO DE BARROS. Relatório anual. Sorocaba, SP, v. 1, 2009.

CENTRO DE EDUCAÇÃO AMBIENTAL DO PARQUE ZOOLÓGICO MUNICIPAL QUINZINHO DE BARROS. Relatório anual. Sorocaba, SP, v. 2, 2009.

CENTRO DE GESTÃO E ESTUDOS ESTRATÉGICOS (CGEE); MINISTÉRIO DA CIÊNCIA, TECNOlOGIA E INOVAÇÃO (MCTI). Percepção Pública da C\&T no Brasil 2015. Disponível em: <percepcaocti.cgee.org.br/>. Acesso em: 29 de agosto de 2015.

CERATI, T. M. Educação em jardins Botânicos na Perspectiva da Alfabetização Científica: Análise de uma Exposição e Público. Tese (Doutorado) - Faculdade de Educação da USP, São Paulo. 2014.

CIÊNCIA EM REDE. Acervo material didático-cultural - GEENF. Disponível em: http://www.cienciaemrede.com.br/2012/05/acervo-material-didatico/. Acessado dia: 10 de agosto de 2015 .

CHAGAS, I. Aprendizagem não formal/formal das ciências: Relações entre museus de ciência e escolas. Revista de Educação, v. 3, n .1, p. 51-59, 1993.

CHASSOT, A. Alfabetização Científica: uma possibilidade para a inclusão social. Revista Brasileiro de Educação, n. 22, p. 89-100, 2003.

CHERUTTI, G; MATHIAS, M. O.; GARCIA, V. A. R. Utilização da sacola ecológica como recurso didático do zoológico "Quinzinho de Barros" na Educação Ambiental em espaços nãoformais de aprendizagem. Educação: Teoria e Prática, v. 21, n. 37, 2011.

CHITTENDEN, D.; FARMELO, G.; LEWENSTEIN, B. Creating connections. Museums and the Public Understanding of Current Research, Walnut Creek: AltaMira Press, 2004.

CHIZZOTTI, A. A pesquisa qualitativa em ciências humanas e sociais: Evolução e desafios. Revista Portuguesa de Educação, v. 16, n. 2, p. 221-236, 2003. 
COLCIENCIAS. Estrategia Nacional de Apropriacion Social de la Ciencia, la Tecnologia y la Innovacion. Bogotá: Colciencias, 2010. Disponível em: $<$ http://aprendeenlinea.udea.edu.co/lms/moodle/file.php/635/ESTRATEGIA_NACIONA _DE_ASCTI.pdf $>$. Acessado dia: 4 de dezembro de 2015.

CONTIER, D. Relações entre ciência, tecnologia e sociedade em museus de ciências. Dissertação (Mestrado) - Faculdade de Educação da USP, São Paulo. 2009.

CONTIER, D.; MARANDINO, M. Reflexões sobre o uso do conceito de Alfabetização Científica no contexto da educação não formal. In: ENCONTRO NACIONAL DE PESQUISA EM EDUCAÇÃO EM CIÊNCIAS (ENPEC), 10, Água de Lindóia, SP, 2015. Atas... Águas de Lindóia, SP. 2015.

DAZA-CAICEDO, S. La apropiación social de la ciencia y la tecnología como um objeto de frontera. In: VOGT, C.; DIAS, S.; PALLONE, S.; BARATA, G.; KANASHIRO M. (Eds.). Comunicação, divulgação e percepção pública de ciência e tecnologia. Rio de Janeiro: De Petrus, 2013. 2 p. $49-62.00$ Disponível $<$ http://www.academia.edu/8383396/LA_APROPIACI\%C3\%93N_SOCIAL_DE_LA_CIEN CIA_Y_LA_TECNOLOG\%C3\%8DA_COMO_UN_OBJETO_DE_FRONTERA. Acessado dia: 3 de dezembro de 2015.

DEBOER, G. E. Scientific literacy: another look at its historical and contemporary meanings and its relationship to science education reform. Journal of Research in Science Teaching, v. 37, n. 6, p. 582-601, 2000.

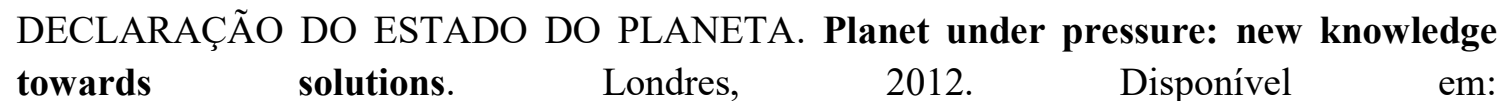
$<$ http://www.planetunderpressure2012.net/pdf/state_of_planet_declaration.pdf $>$. Acessado dia: 3 de dezembro de 2015.

DELICADO, A. Para que servem os museus científicos? Funções e finalidades dos espaços de musealização da ciência. In: Congresso Luso-Afro-Brasileiro de Ciências Sociais, VIII, Coimbra, Portugal. Anais...Coimbra, Portugal, 2004.

DELICADO, A. Scientific controversies in museums: notes from a semi-peripheral country. Public Understanding of Science, v. 18, n. 6, p.759-767, 2009.

DELICADO, A. Going abroad to do science: mobility trends and motivations of Portuguese researchers. Science Studies, v. 23, n. 2, p. 36-59, 2010.

DELIZOICOV, D.; AULER, D. Ciência, Tecnologia e Formação Social do Espaço: questões sobre a não-neutralidade. Revista de Educação em Ciência e Tecnologia, v.4, n.2, p.247-273, 2011.

DEMO, P. Educação e Alfabetização Científica. Campinas: Papirus, 2010.

DENZIN, N. K. Strategies of Qualitative Inquiry. New York: SAGE Publications, 1998. 
DUARTE, R. Pesquisa qualitativa: reflexões sobreo trabalho de campo. Cadernos de Pesquisa, n. 115, p. 139-154, 2009.

EINSIEDEL JR., A. A.; EINSIEDEL, E. F. Museums as Agora: Diversifying approaches to engaging publics in research. In: CHITTENDEN, D.; FARMELO, G.; LEWENSTEIN, B. Creating connections: Museums and public understanding current research. Creek, CA: Altamira Press, 2004.

ELAZARI, J. M. Recursos pedagógicos de Museus: "Kits" de objetos Arqueológicos e Etnográficos. Revista do Museu de Arqueologia e Etnologia, n. 10, p. 351-358, 2000.

ELLIS, D. Cumprindo a missão. In: GUIMARÃES, V.; SILVA, G. A. Implantação de centros e Museus de Ciência. Rio de Janeiro: UFRJ, 2002.

ERDURAN, S.; MUGALOGLU, E. Z. Interactions of Economics of Science and Science Education: Investigating the Implications for Science Teaching and Learning. Science \& Education, v. 22, p. 2405-2425, 2013.

FAGUNDES, V. O. Blogs De Ciência. Comunicação, participação e as rachaduras na Torre de Marfim. Dissertação (Mestrado em Divulgação Científica e Cultural). Instituto de Estudos da Linguagem, Universidade Estadual de Campinas, 2013.

FALCÃO, D. Análise do contexto de criação de aparatos interativos em museus de ciências. In: Encontro Nacional de Pesquisa em Ensino de Ciências (ENPEC), VI, 2007, Anais... Florianópolis, 2007.

FALK, J. H.; DIERKING, L. D. The Museum experience. Routledge: New York, 1992.

FALK, J. H.; DIERKING, L. D. Learning from Museums. Visitor experiences and the making of meanings. Altamira Press: United Kingdom, 2000.

FALK, J. H.; DIERKING, L. D. Museum Experience Revisited. Routlegde: Left Coast Press. 2012.

FALTAY, P. Formação continuada e produção de materiais didáticos em encontros e feiras de ciências em Pernambuco. In: ENCONTRO "PERSPECTIVAS DO ENSINO DE BIOLOGIA, 8, 2002, São Paulo. Anais... São Paulo: CNPQ, p. 1-7, 2002.

FEINSTEIN, N. Salvaging science literacy. Science Education, v. 95, p. 168-185, 2010.

FENSHAM, P. School science and public understand of science. International Journal of Science Education, v.21, n. 7, p. 755-763, 1999.

FERNANDES, B. J. T. Processo de triangulação de perspectivas na pesquisa qualitativa. Disponível em: http://designinterativo.blogspot.com.br/2006/08/processo-de-triangulao-deperspectivas.html. Acessado dia: 29 de julho de 2015.

FERREIRA, G. L.; CARVALHO, D. F. Curiosidade e encantamento: a experiência estética dos visitantes de um museu de ciência. Museologia \& Interdisciplinaridade, v. IV, n. 8, p. 239-251, 2015. 
FIGUEROA, A. M. S. Os objetos nos museus de Ciências: o papel dos modelos pedagógicos na aprendizagem. Tese (Doutorado) - Faculdade de Educação da USP, 2012.

FISCHER, M. C. B. Interlocuções sobre a metodologia qualitativa. UNIrevista, v. 1, n. 1, p. 9$18,2006$.

FLEMING, R.W. Literacy for a technological age. Science Education, v. 73, n. 4, p. 391-404, 1989.

FLICK, U. Qualidade na pesquisa qualitativa. Porto Alegre: Artmed, 2009.

FOUREZ, G. Alphabétisation Scientifique et Technique - Essai sur les finalités de l'enseignement des sciences, Bruxelas: DeBoeck-Wesmael, 1994.

FOUREZ, G. A construção das ciências: introdução à filosofia e à ética das ciências. São Paulo: Editora da Universidade Estadual Paulista,1995.

FOUREZ, G. Science teaching and the STL movement: a socio-historical view. In: JENKINS, E. (Ed.). Innovations in science and technology education. Paris: UNESCO Publishing. v. 6, p. 43-57, 1997.

FOUREZ, G. Crise no ensino de ciências? Investigações em Ensino de Ciências, v.8, n. 2, p. 109-123, 2003.

FOUREZ, G. Alfabetizacón Científica Y Tecnológica: Acerda de las finalidades de La enseñanza de las ciencias. Buenos Aires: Colihue, 2005.

FUJISAWA, D. S. Utilização de jogos e brincadeiras como recurso no atendimento fisioterapêutico de criança: implicações na formação do fisioterapeuta. Dissertação (Mestrado) - Faculdade de Filosofia e Ciências, Universidade Estadual Paulista, Marília, 2000.

FREIRE, P. Educação e mudança. Paz e Terra, São Paulo, 1988.

FREIRE, P. Pedagogia da autonomia saberes necessários à prática educativa. Paz e Terra, São Paulo, 1996.

GARCIA, V. A. R. Avaliação do roteiro de visita orientada do zoobservador. In: VIII Congresso Paulista de Zoológicos, 1999, Bertioga. Anais...VIII Congresso Paulista de Zoológicos, 2003.

GARCIA, V. A. R. O Processo de aprendizagem no Zôo de Sorocaba: análise da atividade educativa visita orientada a partir dos objetos biológicos. Dissertação (Mestrado) Faculdade de Educação da USP, São Paulo. 2006

GARCIA, V. A. R.; MARANDINO, M. Zoológico: será que estamos passando a mensagem certa? In: JORNADAS IBEROAMERICANAS SOBRE CRITERIOS DE EVALUACIÓN DE LA COMUNICACIÓN EN LA CIENCIA, 2006, Memorias... Cartagena de Índias. Www.cientec.or.cr. 
GARCIA, V. A. R MERGULHÃO, M. C. Projeto-piloto de educação ambiental: avaliação do roteiro de visita orientada "Zooobservador", um aliado à prática de educação ambiental em zoológicos. Revista Educação: Teoria e Prática, V. 9, n. 16, p. 4-17, 2001.

GARCIA, V. A. R.; MERGULHÃO, M. C.; ROLIM, V. S. Clube Conservadores da Natureza: um espaço de formação de agentes multiplicadores. In: REUNIÓN DE LA RED DE POPULARIZACIÓN DE LA CIENCIA Y LA TECNOLOGÍA EN AMÉRICA LATINA Y EL CARIBE (RED POP - UNESCO), X Y TALLER “CIENCIA, COMUNICACIÓN Y SOCIEDAD”, 4, Costa Rica. Atas...San José, Costa Rica. p. 1-11, 2007.

GONÇALVES, M. C. S. O uso da metodologia qualitativa na construção do conhecimento científico. Ciência \& Cognição, v. 10, p. 199-203, 2007.

GREGORY, J.; MILLER, S. Science in public: communication, culture and credibility. New York: Plenum Press, 1998.

GUTBERLET, J.; PONTUSCHKA, N. N. Pesquisa qualitativa sobre consumo: experiências interdisciplinares. Revista Olhar do Professor, v. 13, n. 2, p. 217-224, 2010.

HANZEL, R. M.; TREFIL, J. Science matters. Achieving scientific literacy. New York: Anchor Books Doubleday, 1991.

HANZEL, R. M.; TREFIL, J. Alfabetismo científico. La popularización de la ciência y la tecnologia. In: Red de Popularizacion de la ciencia e tecnologia en America Latina y el Caribe, XI, México. Anais Reflexiones básicas... México: Unesco, 1997.

HEIVEIL, I. Videoterapia: o uso do vídeo na psicoterapia. São Paulo: Summus, 1984.

HENRIKSEN, E. K.; FROYLAND, M. The contribution of museums to scientific literacy: views from audience and museum professionals. Public Understanding of Science, v. 9, p. 393-415, 2000.

HINE, A.; MEDVECKY, F. Unfinished Science in Museums: a push for critical science literacy. Journal of Science Communication, v. 14, n. 2, A04 1-14, 2015.

HOOPER-GREENHILL, E. The Educational role of the Museum. London: Routledge, 1994.

HORTA, M. L. P. Educação Patrimonial I. Rio de Janeiro: Ministério da Educação e Cultura, Secretaria da Cultura, Fundação Nacional Pró- Memória, 1984.

HORTA, M. L. P.; GRUNBERG, E.; MONTEIRO, A. Q. Guia Básico de Educação Patrimonial. Brasília: IPHAN / Museu Imperial, 1999.

HURD, P. D. Science literacy: Its meaning for American schools. Educational Leadership, 16, n. 1, p. 13-16; 52, 1958.

HURD, P. D. Scientific literacy: new minds for a changing world. Science Education, v.82, n. 3, p. 407-4016, 1998.

INSTITUTO BRASILEIRO DE MUSEUS, IBRAM. Museus em números. Brasília: IBRAM. v. I, 2011. 
INSTITUTO BRASILEIRO DE MUSEUS, IBRAM. Portal do Instituto Brasileiro de Museus. Disponível em: http://www.museus.gov.br/os-museus/. Acessado dia: 28 de julho de 2015 .

ICOM. International Council of Museums - ICOM. Espanha: julho de 2001. Disponível em: http://icom.museum/definition.html. Acessado dia: 20 de janeiro de 2016.

INTERNATIONAL UNION OF DIRECTORS OF ZOOLOGICAL GARDENS / INTERNATIONAL UNION OF THE CONSERVATION OF NATURE / SPECIES SURVIVAL COMMISSION. The world zoo conservation strategy; the role of the zoo and aquaria of the world in global conservation. Illinois: Chicago Zoological Society, 1993.

JAKOBSSON, A.; DAVIDSSON, E. Using sociocultural frameworks to understanding the significance of interaction at Science and technology centers museums. In: DAVIDSSON, E.; JAKOBSSON, A. Understanding interactions at Science centers and museums. Netherlands: Sense Publisher, 2012.

KNORR-CETINA, K. The Manufacture of Knowledge: An Essay on the Constructivist and Contextual Nature of Science. Oxford: Pergamon Press, 1981.

KRASILCHIK, M. Ensino de Ciências: um ponto de partida para a inclusão. In: WERTHEIN J.; CUNHA, C. Ensino de ciências e desenvolvimento: o que pensam os cientistas. 2 ed. Brasília: UNESCO/ Instituto Sangari, 2009.

KRASILCHIK, M.; MARANDINO, M. Ensino de ciências e cidadania. São Paulo, Moderna, 2004.

KUHN, T. A Estrutura das revoluções científicas. São Paulo: Perspectiva, 2005.

LAGE, N. A reportagem: teoria e técnica de entrevista e pesquisa jornalística. Rio de Janeiro: Record, 2001.

LATOUR, B. Ciência em ação: como seguir cientistas e engenheiros sociedade afora. São Paulo: Editora Unesp. 2000.

LATOUR, B.; WOOLGAR, S. Laboratory life: the construction of scientific facts. London: Sage, 1979.

LAUGKSCH, R. C. Scientific Literacy: A Conceptual Overview. Science Education, v. 84, n. 1, p. 71-94, 2000.

LAYTON, D. Science for specific social purposes (SSSP): perspectives on adults scientific literacy. Studies in Science Education, v. 13, p. 27-52, 1988.

LEINHARDT, G.; CROWLEY, K. Objects of Learning, Objects of Talk: Changing Minds in Museums. University of Pittsburg, 2001. Disponível em: www.museumlearning.com/leinhardtcrowley. pdf. Acessado dia: 26 de junho de 2015.

LEMKE, J. L. Investigar para el Futuro de la Educación Científica: Nuevas Formas de Aprender, Nuevas Formas de Vivir. Enseñanza de las Ciencias, v. 24, n. 1, p. 5-12, 2006. 
LEWENSTEIN, B. V. Models of public communication of science and technology. Disponível

em:

http://disciplinas.stoa.usp.br/pluginfile.php/43775/mod_resource/content/1/Texto/Lew enstein\%202003.pdf. Acessado dia: 16 de agosto de 2016.

LEWENSTEIN, B. V.; BROSSARD, D. Assessing models of public understanding in ELSI outreach materials, U.S. Department of Energy. Cornell: Cornell University, 2006.

LORENZETTI, L.; DELIZOICOV, D., Alfabetização científica no contexto das séries iniciais. ENSAIO - Pesquisa em Educação em Ciências, v. 3, n. 1, p. 37-50, 2001.

LÜDKE, M.; ANDRÉ, M. E. D. Pesquisa em educação: abordagens qualitativas. São Paulo: EPU, 1986.

LUJÁN LÓPES, J. L. et al. Ciencia, tecnología y sociedad: una introducción al estudio social de la ciencia y la tecnología. Madrid: TECNOS, 1996.

MACDONALD, S.; SILVERSTONE, R. Science on display: representation of scientific controversy in museum exhibitions. Public Understanding of Science, 1, 1992. p. 69-87.

MACMANUS, P. What people say and how they think in a science museum. In: UZZELL, D. L. Heritage Interpretation, London: Belhaven, v. 2: The visitor experience, p. 156-165, 1989.

MACMANUS, P. Oh, yes, they do: How museum visitors read labels and interact with exhibit texts. Curator: The Museum Journal, v. 32, n.3, p. 174-189, 1989.

MACMANUS, P. Topics in museums and science education. Studies in Science Education, n. 20, p. 157-182, 1992.

MARANDINO, M. O conhecimento biológico nas exposições de museus de ciências: análise do processo de construção do discurso expositivo. Tese (Doutorado) - Faculdade de Educação da USP, São Paulo. 2001.

MARANDINO, M. Biologia nos museus de ciências: a questão dos textos em bioexposições. Ciência \& Educação, v. 8, n. 2, p. 187-202, 2002.

MARANDINO, M. A Pesquisa Educacional e a Produção de Saberes nos Museus de Ciências. História, Ciências, Saúde-Manguinhos, Rio de Janeiro, v. 12, p. 161- 181, 2005.

MARANDINO, M. Museus de Ciências, Coleções e Educação: relações necessárias. Revista Eletrônica do Programa de Pós-Graduação em Museologia e Patrimônio, v. 2, n. 2, p. 1$12,2009$.

MARANDINO, M. Os objetos biológicos nos museus de ciências: um estudo no contexto brasileiro. In: EMOND, A. M. (orgs). Le Musée: entre la recherche et L'enseignement. Montreal: Multimondes, p. 99-120, 2012. 
MARANDINO, M. Ciência, Tecnologia e Educação: promovendo a alfabetização científica de jovens cidadãos. In: DAYRELL, J.; CARRANO, P; MAIA, C. L. (Orgs). Juventude e ensino médio: sujeitos e currículos em diálogo. Belo Horizonte: Editora UFMG, 2014.

MARANDINO, M.; BIZERRA, A. F.; NAVAS, A. M.; FARES, D. C.; MONACO, L. M.; MARTINS, L. C.; GARCIA, V. A. R.; SOUZA, M. P. C. Educação em museus: a mediação em foco. São Paulo: Pró-Reitoria Cultura e Extensão USP e GEENF/FEUSP, v. 1, 36 p, 2008.

MARANDINO, M.; MARTINS, L. C.; GRUZMAN, C.; CAFFAGNI, C. W.; ISZLAJI, C.; CAMPOS, N. F.; MÔNACO, L.; SALGADO, M.; FIGUEROA, A. M. S.; BIGATTO, M. A abordagem qualitativa nas pesquisas em educação em museus. In: ENCONTRO NACIONAL DE PESQUISA EM EDUCAÇÃO EM CIÊNCIAS (ENPEC), 7, Florianópolis, 2009. ATAS...Florianópolis, SC, 2009.

MARANDINO, M; MONACO, L; LOURENÇO, M. F., RODRIGUES, J.; RICCI, F. P. A educação em Museus e os materiais Educativos. Faculdade de Educação da USP. 2016. Disponível em http://www.geenf.fe.usp.br/v2/wp-content/uploads/2016/05/Capa-AEducac\%CC\%A7a\%CC\%83o-em-Museus-e-os-Materiais-Educativos.pdf. Acessado dia: 10 de dezembro de 2016.

MARANDINO, M; MARTINS, L. Museu e direitos humanos: reflexões e implicações para educação em museus de ciências. In: OLIVEIRA, R. D. V. L; QUEIROZ, G. R. P. C. Tecendo diálogos sobre direitos humanos na educação em ciências. Niterói, LF Editorial, p. 157-185, 2016.

MARTINS, H. T. S. Metodologia qualitativa de pesquisa. Educação e Pesquisa, São Paulo, v. 30, n. 2, p. 289-300, 2004.

MARTINS, L. C. A relação museu/escola: teoria e prática educacionais nas visitas escolares ao Museu de Zoologia da USP. Dissertação (Mestrado) - Faculdade de Educação da USP, 2006.

MARTINS, L. C. A constituição da educação em museus: o funcionamento do dispositivo pedagógico museal por meio de um estudo comparativo entre museus de artes plásticas, ciências humanas e ciência e tecnologia. Tese (Doutorado) - Faculdade de Educação da USP, 2011.

MASSARANI, L. Comunicação da ciência e apropriação social da ciência: algumas reflexões sobre o caso do Brasil. Uni-pluri/versidad, v. 12, n. 3, p. 92-100, 2012.

MERGULHÃO, M. C. Zoológico: uma sala de aula viva. In: PADUA, S. M.; TABANEZ, M. F. Educação Ambiental: Caminhos Trilhados no Brasil. Brasília: Instituto de Pesquisas Ecológicas, p. 193-200, 1997.

MERgulhão, M. C. Socorro! Tem um bicho aqui! Tese (Doutorado) - Faculdade de Educação da USP, 2002. 
MILLER, J. D. Scientifc Literacy: A Conceptual and Empirical Review. Dedalus, v. 112, n. 2, p 29-48, 1983.

MINAYO, M. C. S. O desafio do conhecimento: pesquisa qualitativa em saúde. 11.ed. São Paulo: Hucitec, 2008.

MINGUES, E. "O Museu vai à praia" análise de uma atividade educativa à luz da alfabetização científica. Dissertação (Mestrado) - Faculdade de Educação da USP, São Paulo, 2014.

MORA, M. C. S. Los museos y la cultura científica: uma aproximación a través del recuerdo de las exhibiciones museográficas. Revista Eletrônica do programa de Pós-Graduação em Museologia e Patrimônio, Unirio/MAST, v.4, n.1, p. 3-27, 2011.

MORAIS, A. M.; NEVES, I. P. Fazer investigação usando uma abordagem metodológica mista. Revista Portuguesa de Educação, v. 20, n. 2, p. 75-104, 2007.

MOREIRA, L. M. O Teatro em Museus e Centros de Ciências: uma Leitura na Perspectiva da Alfabetização Científica. Tese (Doutorado). Faculdade de Educação da USP, São Paulo, 2013.

NASCIMENTO JUNIOR, J.; TRAMPE, A.; SANTOS, P. A. (ORGS). Mesa redonda sobre a importância e o desenvolvimento dos museus no mundo contemporâneo: Mesa Redonda de Santiago do Chile, 1972. Brasília: Ibram/Minc, Programa Ibermuseos, v. 1, 2012. 235 p. Disponível em: http://www.ibermuseus.org/wpcontent/uploads/2014/09/Publicacion_Mesa_Redonda_VOL_I.pdf. Acessado dia: 21 de janeiro de 2016.

NASCIMENTO, S. S.; VENTURA, P. C. A dimensão comunicativa de uma exposição de objetos técnicos. Ciência \& Educação, v. 11, n. 3, p. 445-455, 2005.

NORRIS, S. P.; PHILlIPS, L. M. How Literacy in Its Fundamental Sense is Central to Scientific Literacy. Science Education, v. 87, n. 2, p. 224-240, 2003.

OLIVEIRA, D. Biodiversidade em políticas públicas de Ciência, Tecnologia e Inovação: caracterização e perspectivas na integração do fomento à divulgação e educação em ciências. Tese do Programa de Pós-Graduação em Educação em Ciências: Química da Vida e Saúde da Universidade Federal do Rio Grande (FURG) -Associação ampla FURG/ UFRGS/ UFSM, 2016.

PATTON, M. Q. Qualitative research \& evaluation methods. 3.ed. London: Sage Publications, 2001.

PEDRETTI, E. Kuhn meets T. Rex: Critical conversations and new directions in science centers and science museums. Studies in Science Education, v. 37, n. 1, p. 1-41, 2002.

PEDRETTI, E.; IANNINI, A. M. N.; NAZIR, J. Critical exhibits and public engagement: challenges and possibilities. In: INTERNATIONAL PUBLIC COMMUNICATION OF 
SCIENCE AND TECHNOLOGY CONFERENCE. 13, Salvador, Brazil., Anais... SALVADOR, 2014.

PELLA, M. O.; O'HEARN, G. T.; GALE, C. G. Referents to scientific literacy. Journal of Research in Science Teaching, v. 4, 199-208, 1996.

PERÉZ, C. A.; MOLINI, A. M. V. Consideraciones generales sobre la alfabetización científica em los museos de la ciência como espacios educativos no formales. Revista Eletrónica de Enseñanza de las Ciencias, v. 3, n. 3, p. 339-362, 2004.

PIRES, J. P. Atividade lúdica e aprendizagem. Revista Portuguesa de Pedagogia, n.3, p. 385$386,2016$.

PONTACOROLO, A. R.; CAPUANO, R. T. As coleções biológicas como instrumento de educação e conservação da biodiversidade do planeta. In: CONVERSANDO SOBRE EXTENSÃO (CONEX), 9º Ponta Grossa, PR. p. 1-4, Anais... Ponta Grossa, PR, 2011.

PRAIA, J.; GIL-PEREZ, D.; VILCHES, A. O papel da natureza da ciência na educação para a cidadania. Ciência \& Educação, v.13, n. 2, p.141-156, 2007.

REEVE, J. Material didático em Museus. In: STEPHENS, M. Culture, Education and the State. Routledge: Routledge Library Editions, p. 65-93. 1988.

REIGOTA, M. O que é educação ambiental. Coleção primeiros passos. São Paulo: Editora brasiliense, 2001.

RENNIE, L. J.; JOHNSTON, D. J. The nature of learning and its implications for research on learning from museums. Science Education, v. 88, n. S1, p. S4-S16, 2004.

REYNA, C. P. Vídeo e pesquisa antropológica: encontros e desencontros. Disponível em: http://bocc.ubi.pt/pag/reyna-carlos-video-pesquisa.pdf. Acessado dia: 22 de julho de 2015.

RIVIÉRE, G. H. Seminário regional de la Unesco sobre la función educativa de los museus. Rio de Janeiro/UNESCO, 1958.

ROBERTS, D. A. Scientific Literacy/Science Literacy. In: ABELL, S. K.; LEDERMAN, N. G. Handbook of research in science teaching and learning. New York: McMillan, 2007.

ROCHA, J. N. Museus e centros de ciências itinerantes: Análise das exposições e processos de alfabetização científica. Qualificação da tese (Doutorado). Faculdade de Educação da Universidade de São Paulo, São Paulo, 2016.

ROJAS, J. E. A. O indivisível e o divisível na história oral. In: MARTINELLI, M. L. Pesquisa qualitativa: um instigante desafio. São Paulo, Veras, p. 87-94, 1999.

RUBIO, A. I. G. La Maleta Pedagógica: um proyecto educativo para el Museo Nacional de Machado Castro. Imafronte, n. 15, p. 85-102, 2000.

SABATINI, m. Museus e centros de ciência virtuais: uma nova fronteira para a cultura científica. ComCiência, 2014. Disponível em: 
http://www.comciencia.br/reportagens/cultura/cultura14.shtml. Acessado dia: 28 de julho de 2015.

SANTOS, W. L. P. Educação científica na perspectiva de letramento como prática social: funções, princípios e desafios. Revista Brasileira de Educação, Rio de Janeiro. v. 12, n. 36, 2007.

SANTOS, W. L. P.; MORTIMER, E. F. Uma análise de pressupostos teóricos da abordagem C-T-S (Ciência-Tecnologia-Sociedade) no contexto da educação brasileira. Ensaio: pesquisa em educação em ciências, v. 2, n. 2, p. 133-162, 2000.

SANTOS-GOUW A. M.; PEREIRA H. M. R.; CONTREIRAS, J. C. N. Análise dos materiais educativos de algumas exposições darwinistas no Ano Darwin. In: ENCONTRO NACIONAL DE PESQUISA EM EDUCAÇÃO EM CIÊNCIAS (ENPEC), 8, UNICAMP, Campinas. Atas... Campinas, SP, 2011.

SÁ-SILVA, J. R.; ALMEIDA, C. D.; GUINDANI, J. F. Pesquisa documental: pistas teóricas e metodológicas. Revista Brasileira de História \& Ciências Sociais, v.1, n. 1, p. 1-14. 2009.

SASSERON, L. H. Alfabetização Científica no Ensino Fundamental: Estrutura e Indicadores deste processo em sala de aula. Tese (Doutorado) - Faculdade de Educação da USP, 2008.

SASSERON, L. H.; CARVALHO, A. M. P. Alfabetização Científica: uma revisão bibliográfica. Investigação em Ensino de Ciências, v.16, n. 1, p 59-77, 2011.

SCAPPATICCI, A. L. S. S.; IACOPONI, E.; BLAY, S. L. Estudo de fidedignidade interavaliadores de uma escala para avaliação da interação mãe bebê. Revista de Psiquiatria, v. 26, n. 1, p. 39-46, 2004.

SCHRAIBER, L. B. Pesquisa qualitativa em saúde: reflexões metodológicas do relato oral e produção de narrativas em estudo sobre a profissão médica. Revista de Saúde Pública, São Paulo, v. 29, n. 1, p. 63-74, 1995.

SHAMOS, M. The myth of scientific literacy. New Brunswick, NJ: Rutgers University Press, 1995.

SHEN, B. S. P. Science literacy. American Scientist, n. 63, p. 265-268, 1975.

SISMONDO, S. An introduction to science and technologies studies. Singapura: Blackwell Publishing, 2010.

STOCKLMAYER, S. Exposições interativas: o que os visitantes estão realmente fazendo. In: GUIMARÃES, V.; SILVA, G. A. Implantação de centros e Museus de Ciência. Rio de Janeiro: UFRJ, 2002.

STUDART, D.; ALMEIDA, A. M.; VALENTE, M. E. A. Pesquisa de público em museus: desenvolvimento e perspectivas. IN: GOUVÊA, G.; MARANDINO, M; LEAL, M. C. (ORG.). 
Educação e museu: a construção social do caráter educativo dos museus de ciência. Rio de Janeiro: Faperj/Access, p. 129-157, 2003.

TEIXEIRA, J. N. Experimentos surpreendentes e sua importância na promoção da motivação intrínseca do visitante em uma ação de divulgação científica: um olhar a partir da Teoria de Autodeterminação. Tese (Doutorado). Instituto de Física e Faculdade de Educação da Universidade de São Paulo, São Paulo, 2014.

THOMAS, G.; DURANT, J. Why should we promote the public understanding of science? Scientific literacy papers, v. 1, p.1-14, 1987.

TUNNICLIFFE, S. D. Live Animals as exhibits. Journal of the International Association of Zoo Educators, Los Angeles. p. 34-40, 1995.

TUNNICLIFFE, S. D. Conversations within primary school parties visiting animal specimens in a museum and zoo. Journal of Biological Education. n. 30, v.2, p.130-141, 1996.

VALDECASAS, A. G.; CORREAS, A. M. Science Literacy and natural history museums. Journal of Biosciences, v. 35, n. 4, p. 507-514, 2010.

VALENTE, M. E. Educação em museu: o público de hoje no museu de ontem. Dissertação (Mestrado), Pontifícia Universidade Católica do Rio de Janeiro (PUC-Rio), Rio de Janeiro, 1995.

VALENTE, M. E. A Conquista do Caráter Público do Museu. In: GOUVÊA, G.; MARANDINO, M.; LEAL, M. C. (ORG.). Educação e Museu: a construção social do caráter educativo dos museus de ciências. Rio de Janeiro: Editora Access/Faperj, p. 83-106, 2003.

VALENTE, M. E. A. O museu de ciência: espaço da história da ciência. Ciência \& Educação, v. 11, n. 1, p. 53-62, 2005.

VALENTE, M. E.; CAZELLI, S; ALVES, F. Museus, ciência e educação: novos desafios. História, Ciências, Saúde - Manguinhos, v.12, suplemento, p. 183-203, 2005.

VÄN-PRAET, M.; POUCET, B. Les Musées, Lieux de Contre-Éducation et de Partenariat Avec L'École, In: Education \& Pédagogies - dés élèves au musée, n. 16, p. 21-29, 1992.

VASCONCELLOS, C. de M. Recursos pedagógicos no Museu de Arqueologia e Etnologia da USP. São Paulo: MAE-USP, 2014.

VOGT, C. Cultura científica: desafios. São Paulo: Edusp/FAPESP, 2006.

WAGENSBERG, J. Principios Fundamentales de la Museología Científica Moderna. Alambique - Didáctica de Las Ciencias Experimentales, n. 26, p. 15-19, 2001.

WAGENSBERG, J. The "total” museum, a tool for social change. História, Ciências, Saúde, v. 12, suplemento, p. 309-332, 2005. 
ZABALA, A. A prática educativa - como ensinar. Porto Alegre, RS: Artmed. 1998.

ZOO SOROCABA. http://www.sorocaba.sp.gov.br/zoo/. Acessado dia: 20 de novembro de 2016. 
APÊNDICE A - Questões que orientaram as entrevistas semiestruturadas com os responsáveis pela concepção e gerenciamento dos materiais educativos do Parque Zoológico Municipal Quinzinho de Barros.

\section{Entrevista com a responsável pelo empréstimo dos materiais educativos do Zôo de Sorocaba.}

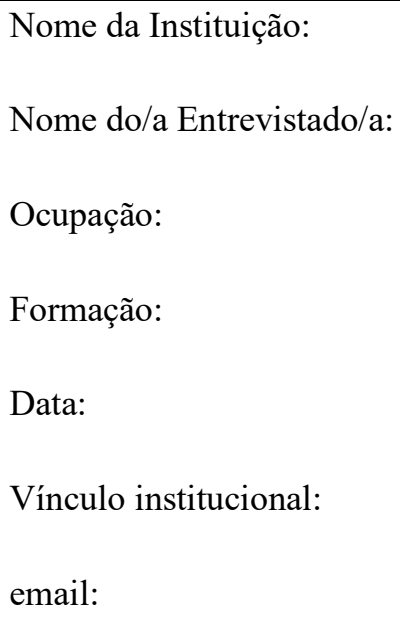

1. Qual seu vínculo com a instituição?

2. Qual a sua função na instituição? Que atividades desenvolve?

3. Quanto tempo está nesta função?

\section{Sobre a Instituição:}

4. Que ações voltadas ao público a instituição desenvolve?

5. Que públicos atende?

\section{Materiais educativos:}

6. Quais tipos de materiais são emprestados para os professores?

7. Quais eram os objetivos do material educativo? Houve alterações desses objetivos ao longo do tempo?

8. Quando o material é usado? Como? Descreva exemplos de situações de uso.

9. Quem é o responsável hoje pelos materiais?

10. Você tem avaliação deste trabalho feito pelos professores? 


\section{Entrevista com as responsáveis pela concepção e gerenciamento dos materiais educativos do Zôo de Sorocaba.}

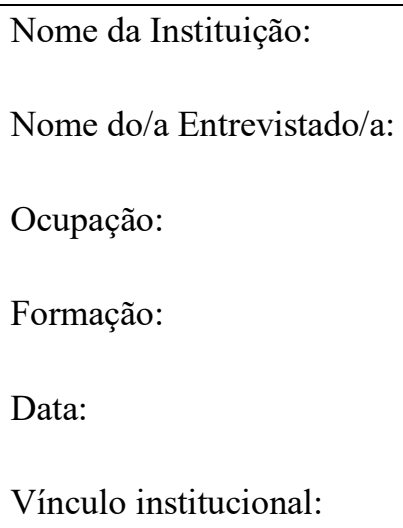

1. Qual seu vínculo com a instituição?

2. Quanto tempo esteve na instituição e qual era sua função?

\section{Materiais educativos:}

3. Como você se envolveu com o uso e/ou produção dos materiais educativos nas ações do Zôo?

4. Esses materiais são adquiridos ou produzidos por vocês? O que a estimulou a produzir os materiais?

5. Quais eram os objetivos do material educativo? Houve alterações desses objetivos ao longo do tempo?

6. Quais as características físicas dos materiais? Descreva-os.

7. Para qual público foi planejado o material? Por que?

8. Quais eram os pressupostos (científicos, pedagógicos, de comunicação) para a produção do material?

9. Quando o material é usado? Como? Descreva exemplos de situações de uso.

10. Que conteúdos e conceitos científicos ele aborda? Como?

11. Como se espera que o público utilize este material?

12. O que se deseja que o público compreenda com este material? Por que? 
13. Houve avaliação dos materiais? Como foi?

14. Que efeitos você avalia que o material teve sobre o público que o utilizou? Por que?

15. Você acha que o material contribui para a compreensão dos conceitos científicos para os quais foi planejado?

16. O material educativo possibilita o entendimento de processos, métodos ou levantamento de hipóteses relacionados à produção científica?

17. O material apresenta ou identifica, em algum momento, a instituição ao qual está ligado? Como?

18. Como o material sinaliza a importância das coleções mantidas pela instituição?

19. os materiais produzidos despertam discussões polêmicas? Dê exemplos.

20. O material estabelece relações entre o conhecimento científico e o cotidiano do público? Por quê?

21. Você acredita que os materiais educativos podem levar o usuário a melhorar a autonomia e capacidade crítica?

22. Você acredita que o uso desses materiais contribui para o envolvimento do público com o tema desenvolvido pela instituição? Como?

23. Que tipo de reações e atitudes o material desperta no público durante a interação? 
APÊNDICE B - Protocolo para registro das observações dos materiais educativos do

Parque Zoológico Municipal Quinzinho de Barros.

\begin{tabular}{|c|c|c|c|c|c|c|c|}
\hline Nome & $\begin{array}{c}\text { Conteúdo/ } \\
\text { conceitos }\end{array}$ & $\begin{array}{c}\text { Indicação } \\
\text { de quando } \\
\text { usar }\end{array}$ & $\begin{array}{c}\text { Indicação } \\
\text { de como } \\
\text { usar }\end{array}$ & Itens & Descrição & Autoria & $\begin{array}{c}\text { Indicadores e } \\
\text { atributos de } \\
\text { AC }\end{array}$ \\
\hline & & & & & & & \\
\hline & & & & & & & \\
\hline
\end{tabular}


APÊNDICE C - Protocolo para fotografar os materiais educativos.

\section{Kits ecológicos}

1. foto geral da embalagem fechada

2. foto geral com a tampa aberta e os objetos dentro da embalagem

3. foto geral com os objetos do lado de fora da embalagem

4. foto dos objetos juntos sem a embalagem

5. fotos de detalhes de cada objeto

\section{Mochila}

1. foto geral da mochila fechada

2. foto da mochila aberta com os objetos dentro

3. foto da mochila com os objetos ao lado

4. foto de detalhe de cada objeto 
APÊNDICE D - Diálogos das crianças e monitor durante a interação com o material "mochila de curiosidades" indicando em amarelo as SDRs (Sequência de diálogos representativos)

COLETA DE DADOS (GARCIA, 2006)

08 de outubro de 2004

Legendas utilizadas nos diálogos:

M: monitor

$\mathrm{CV}$ : várias crianças

$\mathrm{C} 1, \mathrm{C} 2, \mathrm{C} 3$ : crianças específicas.

P: professora

\section{A- Objeto biológico trabalhado: bico de tucano}

1. M: "Bom, a grade de proteção é para proteger a gente do bicho e o bicho da gente. Porque a gente pode machucar o bicho e o bicho machucar a gente... Não pode dar comida pro bicho porquê..."

2. C1: "Porque o bicho pode morrer."

3. M: "Aqui no zoológico a gente tem a alimentação balanceada dele, para ele comer e não ficar gordo nem magro. Vamos fazer a visita (o monitor passa pelo recinto do pavão e do macaco babuíno até chegar no animal escolhido para trabalhar na visita)

4. SDR 1 - M: Vamos dar uma olhada nesse bicho aqui, oh... que bicho que é esse aqui? "

5. Cv: "Tucano".

6. Cv: "Arara".

7. M: "Arara ou tucano"?

8. Cv: "Tucano".

9. : M: Tucano, deixa eu abrir minha mochila mágica aqui, ninguém pode olhar aqui

dentro. Pessoal vamos todos olhar para o bicho lá, todo mundo olhando para o tucano lá. Esse bico dele é comprido, né!"

10. Cv: "É".

11. M: "Mas será que este bico é pesado"?

12. Cv: É.

13. M: "Eu tenho um aqui comigo, aqui, oh... Olha só".

14. C1: "É de verdade tio"?

15. M: "É de verdade".

16. C1: "Deixa eu ver"?

17. C2: "De um que morreu"?

18. M: "É, todo mundo vai poder passar a mão nele, mas agora minha pergunta principal é..”.

19. C1: "É um que morreu?"

20. M: "É um que morreu. Ninguém matou o bicho pra pode pegar o bico, ele morreu de velho, ou doente, ou a Polícia Ambiental trouxe já para cá doente ou morto. Daí a gente pega aqui para poder dar aula e poder mostrar para o pessoal. Esse bico aqui, olha o tamanho do bico dele lá?" (todas as crianças viram para olhar o animal vivo). 
21. C2: "É leve".

22. SDR 2: M: "Olha o tamanho dele. O tamanho é quase o tamanho do bico dele, não é? E este bico, será que é pesado?".

23. C1: "Não, é leve".

24. 23. M: "Porque será?"

25. 24. C3: "Por quê? Porque ele já é pesado".

26. 25. P: "Se fosse pesado, como iria ser para ele?".

27. 26. M: "Se fosse pesado, como ia ser"?

28. 27. C3: "Ele ia ficar assim, oh..."

29. 28. C4: "Ele ia ficar caindo tio".

30. 29. C5: "Tio, porque ele já morreu?"

31. 30. C2: "Ô, professor se fosse pesado, daí ele não conseguia voar."

32. 31. M: "Vocês concordam comigo que se ele fosse pesado, ele ia voar assim. (neste momento o monitor imita o tucano voando com a cabeça para baixo). Não ia voar assim com o bico para baixo assim, oh... Caído, porque o tucano voa assim, oh... Olha o tucano voando.".

33. C1: "Tem dois!"

34. M: "Tem três aqui, tem um monte.".

35. C1: "Oh! Tá com a cara, bico na grade para querer morder."

36. M: "Gente, quem falou que é leve, mandou muito bem."

37. Cv: "Eu falei"

38. M: "Esse bico é muito leve, depois eu vou passar para vocês, já comeram aquele chocolate aerado que é cheio de furinho?".

39. Cv: "Aha."

40. M: "Ele é quase a mesma coisa, ele é todo cheio de furinho, porque ele precisa ser bem leve para poder voar. Se a ave tivesse o osso pesado, igual ao nosso, você acha que ela ia conseguir voar?".

41. Cv: "Não."

42. M: "O osso dela tem que ser leve".

43. C3: "Por isso que alguns bichos não voam, por causa que o osso é pesado."

44. SDR 3: M: Dá uma olhada no bico dele ai oh... Esse bico é leve, não é?”.

45. C1: "É."

46. M: "Mas será que é forte ou será que é pesado?"

47. C1: "É forte".

48. M: "Forte ou fraco?"

49. Cv: "Fraco

50. M: "Quem falou que é fraco errou".

51. C2: "Eu falei".

52. M: "Esse bico é muito forte. Sabe o que o tucano come? O que vocês acham que o tucano come?"

53. Cv: "Folha."

54. M: "Folha, Ah, O que mais? O quê que a arara come?"

55. C1: "O tio olha para aquele lá."

56. M: "Tem um monte.” (neste momento à maioria das crianças está olhando para outro animal).

57. C1: "Semente."

58. M: "Quem acha que o tucano come semente levanta a mão."(somente três crianças levantaram a mão, as demais estavam interessadas no macaco solto que estava em cima da árvore).

59. C1: "Semente de Girassol." 
60. M: "Quem já comeu aqueles coquinhos. Cadê, deixa eu ver se tem algum por aqui. " (o monitor observa o espaço que está para ver se não há uma palmeira com coquinhos).

61. Cv: "Eu já comi Tio."

62. M: "Oh, sabe esses coquinhos que tem... O tucano com esse bicão aqui, ele quebra a semente, e ele come o coquinho. Esse bico é muito forte.

63. SDR 4: M: O tucano também faz uma coisa super legal, ele gosta de comer ovo."

64. Cv: "Ovo?"

65. M: "O que ele faz? Olha a língua dele, ali oh... Será que dá para ver a língua dele ali, oh?"

66. Cv: "Eu tô vendo".

67. C1: "É uma língua preta."

68. M: "Tem um língua ali, oh. Parece uma barberinha, bem no meio do bico, assim do vão do bico dele."

69. C1: "É preta, né tio?"

70. P: "É comprida."

71. C2: "Qual é o tamanho?"

72. M: "É do tamanho do bico. O que ele faz? Ele fura."

73. C6: "A língua dele fica um pouquinho para fora!"

74. M: "É, dá para ver ali, oh."

75. C3. "Eu tô vendo."

76. C6: "Ah, agora eu tô vendo ali, oh, a linguinha dele ali."

77. M: "Ele fura e oh, lambe o ovo e manda o ovo para dentro. Come o ovo também."

78. C1: "A Gema?"

79. M: "Ele come tudo."

80. C1: "A casca branca não?"

81. SDR 5: M: "Oh, eu vou fazer o seguinte, vou passar para vocês. Tem que tomar super... cuidado, é super precioso este daqui."

82. C4: "É de ouro."

83. P: "Não. É um bico leve."

84. C1: "É especial. É único, né tio?"

85. M: "Não, a gente tem mais aqui. Mas olha só, quem vai pegar nele vai falar se ele é leve ou pesado. É muito leve né! Nem parece que é desse jeito. Parece ser super leve e ele nem é muito forte."

86. C2: "É sim, tio!"

87. C2: "Igual a um serrote. (o aluno manuseia o bico e passa o dedo na fase interior do bico, serrilhada)"

88. M: "O tucano come semente e um monte de frutas." (neste momento as crianças estão manuseando o bico do tucano).

89. C1: "Também come semente de girassol?"

90. M: "Pode ser também, se tiver, ele come também. Pessoal uma coisa também, que o tucano faz que é super legal: lembra o coquinho que eu falei para vocês, que ele pega a semente, ele vai lá, detona a semente e depois cospe a semente. Sabe o que vai acontecer com essa semente que caiu no chão?"

91. C3: "Vai nascer."

92. M": Vai nascer o quê?"

93. C7: "Um tucano."

94. C3: "Uma árvore."

95. M: "Uma árvore de coquinho, não é verdade? Ai vai ter mais comida para ele comer, não é verdade? E é isso que o tucano faz. Ele faz a dispersão de sementes, que a 
gente fala, ele faz ter mais planta na natureza. Então é bom ter tucano na natureza? É bom ou não é? Por quê?"

96. C1: Porque ele é muito bom e é da natureza. E ele

97. M: Ele aumenta a floresta.

98. C1: "E ele é da... do bicho e não machuca ninguém." (nesse momento as crianças continuam a manusear o bico do tucano)

99. P: "Como é que é o biquinho dele? Põe a mão no biquinho para ver se é duro mesmo." (a professora continua orientando as crianças para observarem o bico e manuseá-lo, destacando suas estruturas, como o serradinho).

100. C: "Se fosse mole não ia conseguir voar."

101. C: "Se fosse pesado não ia conseguir voar."

\section{2 - Objeto biológico trabalhado: muda e guizo de cobra cascavel}

102. SDR 6: M: "Gente vou fazer uma pergunta para vocês e quero saber de que bicho que é.".

103. C6: "Lagarto."

104. M: "O que é isso? Alguém sabe o que é isso aqui?" (neste momento o monitor mostra e chacoalha o guizo da cobra cascavel no ouvido deles)

105. C6: "Um ovo de..."

106. C1: "Eu já sei! Da cobra!"

107. M: "O que é?"

108. C1: "Da cascavel da cobra, o rabinho."

109. M: "O rabo, como se chama isso?"

110. C6: "Eu sei!"

111. C1: "Ô tio, deixa eu passar a mão

112. C3: "Tio, é o ovo de cobra?” (o aluno repetiu várias vezes)

113. M: "Põe no ouvido."

114. C3: "Tio, eu já sei o quê é que é. É um ovo de cobra."

115. M: "Não, não é."

116. C6: "É o guizo da cobra cascavel."

117. M: "Muito bem. Parabéns! Gente, esse aqui é o guizo de uma cascavel. A cascavel é uma cobra que chama atenção quando algum animal chega perto dela."

118. C1: "É para ninguém chegar perto dela, se não ela come."

119. M: "É, por exemplo, eu estou andando na floresta e ouço o barulho bem alto, aí eu já sei que tem uma cascavel."

120. C1: "Daí a gente tem que fugir."

121. M: "Isso é uma forma dela avisar, cuidado, eu estou aqui e não quero briga com você, eu não quero fazer nada de mal para vocês. Então é melhor você sair daqui que eu vou para o meu lado, é uma forma dela avisar.

122. M: Eu vou fazer uma pergunta, cobra tem pele?"

123. Cv: "Não."

124. Cv: "Tem." (as respostas divergem)

125. M: "Cobra tem osso?"

126. Cv: "Tem."

127. Cv: "Não."

128. CI: "Esqueleto."

129. M: "Quem acha que tem osso, levanta a mão? "(cinco levantaram).

130. M: "Quem acha que não tem osso, levanta a mão?” (três levantaram). 
131. M: "Vamos fazer um teste? Todo mundo comigo aqui. Põem a mão no pescoço, põem a mão aqui (o monitor indica para pôr as mãos nas vértebras). O que a gente tem aqui?" (o monitor aponta para as vértebras do pescoço e das costas).

132. CI: "Aqui tem osso."

133. M: "Como é o nome? Aqui é a costela, não é? A cobra, ela tem um pescoço, uma coluna cheia de costela. Dá uma olhada aqui, oh! (neste momento o monitor conduz as crianças para observar o esqueleto de cobra que está na exposição) - Olha só o osso da cobra aqui, oh! - Gente, uma cobra pode ter mais de 100 pares de costelas - Tem muita costela."

134. SDR 7: M: "Pessoal o que é isso aqui?" (o monitor apresenta a pele da cobra)

135. C2: "Pele dela."

136. M: "Pele dela?"

137. C1: "É tio, pele dela."

138. C6: "Casca dela."

139. M: "Ela tira a pele dela?"

140. C6: "Ela muda de casca."

141. M: "Porque será que ela muda de casca?"

142. C2: "Pra ela dizer quando tá velho, ela troca."

143. M: "Elas estão falando para mim que cobra troca de roupa."

144. C1: "Troca de casca."

145. C4: "Tio troca de roupa."

146. M: "Então vocês falaram para mim que cobra troca de roupa." (nesse momento o monitor pede para todos se sentarem).

147. M: "Pessoal, vou fazer um pergunta para vocês. Quantos anos vocês têm?"

148. C8: "Sete."

149. M: "Sete. Quando vocês estiverem com vinte e um anos, igual eu tenho, você acha que vai servir nessa roupa que está usando hoje?"

150. Cv: "Não."

151. M: "Você vai crescer, não vai? Vai ter que trocar esta roupa. Tem que comprar roupa maior. A cobra compra roupa maior?"

152. Cv: "Não."

153. M: "Então, o que é que ela faz?"

154. C1: "O tio, ela tá com uma... ela vai no meio das pedras, daí quando ela tirar uma, já vai ter outra na pele dela."

155. M: "Muito bem! Ela falou tudo certinho. A cobra, quando começa apertar esta roupa aqui, o que ela faz? Ela arrasta no meio das pedras, ela troca, e vai saindo essa pele da cabeça, até a ponta do rabo, certinho do jeito que está aqui, oh (o monitor mostra a muda da cobra que está em suas mãos)."

156. C1: "O tio, deixa eu catar?"

157. M: "Embaixo já vai ter uma outra pele para ela poder... com uma pele maior e mais folgada, para ela comer um montão, crescer e trocar de pele de novo. As cobras nunca param de trocar de pele, elas estão sempre trocando de pele.

158. M: "É verdade que cobra come ovo?"

159. C1: "É."

160. M: "Tem cobra que come ovo. Tem cobra que come peixe."

161. C2: "Tem cobra que come passarinho."

162. M: "É mesmo! Bem lembrado! As cobras comem de tudo, sapo, comem de tudo.

163. SDR 8: M: Lembra do guizo que eu mostrei para vocês? Tem uma coisa engraçada na cascavel, toda vez que ela troca essa pele aqui, ela ganha um guizo. Se ela trocar três vezes, essa cobra, de pele ao ano, quantos guizos ela vai ganhar?" 
164. Cv: "três."

165. M: "Se ela trocar uma vez no ano só?"

166. Cv: "Um."

167. M: "Se ela trocar duas vezes no ano?"

168. Cv: "Duas."

169. M: "Então é certo falar que a cobra tem cinco guizos. Então ela tem cinco anos."

170. C1: "É."

171. Cv: "Não."

172. M: "Não é. Cada vez que ela troca de pele, ela ganha um guizo. Ela pode trocar de pele duas, três vezes no ano, e esse guizo é muito frágil, pode quebrar muito fácil. Então não dá para saber a idade da cascavel, então, quanto mais barulho, mais velha ela é, mais guizo ela tem."

173. C1: "O tio, essa cobra aí, vocês não cuidam dela?".

174. M: "Cuida."

175. C1: "Como dá comida para a cobra?"

176. M: "Como a gente dá comida para ela? Vocês estão vendo aquela telinha... então nós erguemos a telinha e jogamos o alimento dela."

177. C1: "Tio, ela morde vocês?"

178. M: "Não, é difícil. O que a cobra come aqui no zoológico?"

179. C1: "Ovo."

180. C2: "Comida."

181. M: "Que tipo de comida?"

182. C2: "Uh, de fruta."

183. M: "Deixa eu falar uma coisa para vocês: cobra não come fruta, cobra só come carne."

184. C1: "Então elas são carnívoras, tio?"

185. M: "São carnívoras. Então, o que a gente dá para ela aqui no zoológico, normalmente, damos camundongo, filhotinho de rato."

186. C1: "Rato vivo?"

187. M: "Vivo."

188. C1: "Que nojo"

189. M: "Que nojo? Quem come vaca?"

190. C1: "Eu."

191. M: "Ela acha nojento vaca."

192. C1: "Eu como vaca."

193. SDR 9: M: “Oh, eu vou deixar segurar aqui, mas, oh devagar! Vamos passar a mão devagar! Não vamos ter pressa (neste momento o monitor deixa as crianças manusearem a muda da cobra cascavel)."

194. C1: "Ai, credo!"

195. C1: "Dá um beijinho! Deixa eu passar a mão no rabinho dela?

196. C1: "É mole, né!"

197. M: "Quando ela troca de pele, ela sai cheia de xixi, toda molhada, daí a gente lava ela e ela fica desse jeito aqui (o monitor mostra a pele). Então essa daqui já está quebrada, mas quando ela sai, ela sai perfeita. Oh! Esta aqui trocou de pele há pouco tempo.”

198. C2: "Oh, filhotinho!

199. M: "Esta aqui é filhotinho de cascavel."

200. C2: "Tio, a pequenininha também troca de pele?"

201. M: "Oh, troca. Ela é quem troca mais, porque ela tá crescendo muito, em pouco tempo."

202. C1: "E ela morde?" 
203. M: "Morde. Desde pequenina ela já tem veneno. Oh, olhe aquela pequenina, já tem seu guizo. Olhe ali na ponta, ele é pequenino ai crescendo."

204. C1: "Tio, por que tem aqueles buraquinhos ali?"

205. M: "Para ela se esconder. Olha só, aqui são todas as venenosas, aqui a gente tem, oh, a cascavel"

206. C1: "Tio, onde que elas moram?"

207. M: "Onde as cobras moram? Na floresta, e aparecem de vez em quando na casa de um monte de gente, sabe por quê? Oh pessoal, essa aqui é da Região de Sorocaba na região de Cerrado (o monitor aponta para a cobra...). Você mora onde?"

208. C1: "Sorocaba, Parque São Bento"

209. M: "No Parque São Bento tem também"

210. C1: "Moro no sítio"

211. M: "Oh, essa aqui é a Urutu Cruzeiro, essa cobra aqui também tem na região onde vocês moram"

\section{3- Objeto biológico trabalhado: ovo e perna de ema}

212. C1: "O tio eles tão chocando?"

213. M: "Oh pessoal, todos sentados no chão."

214. C1: "O tio olha a fêmea?" (a criança aponta para o animal que está chocando)

215. C3: "Ah, ah, a fêmea é aquela."

216. M: "Qual que é a fêmea?"

217. C3: "Aquela"

218. C1: "É aquela."

219. M: "E aquele ali, qual que é?"

220. C3: "A fêmea."

221. C1: "O macho."

222. C1: "A fêmea."

223. M: "O Macho que cuida dos ovos?"

224. C1: "Não, a fêmea

225. C1: "A fêmea quando ela ...."( o monitor não dá atenção para a criança)

226. SDR 10: M: “Oh! O que, que é isso aqui pessoal?" (neste instante o monitor apresenta o ovo da ema)

227. C1: "Um ovo."

228. C1: "O tio é de verdade"

229. M: "De quem? De galinha? De pato?"

230. Cv: "Não."

231. C3: "Daquele bicho ali, oh."

232. Cv: "Ema." (as crianças falam bem baixinho)

233. C1: "De Ema."

234. M: "De ema, muito bem! A ema mora na região de cerrado. Sabe onde tem cerrado aqui em Sorocaba? Onde?"

235. C1: "Lá no...?"

236. M: "No bairro cerrado, no Éden, no Cajuru, é região de cerrado... Aquela parte lá e só cerrado... Cerrado do Brasil... Tem muito cerrado em Sorocaba.

237. M: A fêmea bota os ovos. Quem será que cuida dos ovos?”

238. C3: "O macho."

239. C1: "A fêmea."

240. C1: "Quem bota é a fêmea. Quem cuida é o..."

241. M: "Quem bota é a fêmea ou é o macho?"

242. Cv: "É a fêmea." 
243. M: "É a fêmea que bota o ovo. E quem cuida do ovo?"

244. Cv: "O macho."

245. C3: "Então é o macho aquele."

246. M: "O macho, muito bem! O macho é quem fica responsável por chocar os ovos e cuidar dos filhotes."

247. C1: "Tio, aqui tem filhotes?"

248. C3: "A fêmea fica sossegada."

249. M: "Vai ter né, a fêmea tá chocando agora, olha só."

250. C1: "E se criar agora nesse momento?."

251. P: "Quanto tempo fica?"

252. SDR 11: C1: "O tio deixa a gente ver" (a criança quer ver os ovos)

253. M: "Vou deixar. Só uma coisa a ema, ela corre, ela voa ou ela nada?"

254. C2: "Ela nada."

255. C1: "Ela voa."

256. M: "Ema voa. Olhem o tamanho da ema". (o monitor conduz as crianças para olharem para a ema do recinto).

257. C1: "A não, não."

258. M: "Imagine uma ema desse tamanho voando e fazendo coco na gente. Imagina o tamanho do coco que ela ia soltar na gente."

259. C1: "Desse tamanho" (a criança mostra com mão o tamanho grande do coco).

260. M: "Enorme, né! Será que ela voa?"

261. Cv: "Não."

262. C1: "Eu acertei tio."

263. M: "Ela mora na região do cerrado. Você sabe como que é o cerrado?"

264. Cv: "Não."

265. M: "Vou contar para vocês. Olha lá turminha, o cerrado é uma região de matos altos, matos mesmo, e árvores bem distantes umas das outras, que pega fogo muito fácil."

266. C1: "Então a natureza..."

267. M: "Então, o que ela precisa saber? Nadar, voar ou correr?"

268. C1: "Voar."

269. M: "Vou pegar uma coisinha aqui. Olhe o tamanho da pata da ema." (neste momento o monitor apresenta a pata e as crianças ficam juntas vendo com cara de espanto e curiosidade).

270. C1: "Ahh..."

271. M: "Essa é uma pata de ema."

272. C1: "E que morreu?"

273. M: "Ela já morreu, já. Será que ela voa, corre ou nada?'

274. C3: "Nada."

275. Cv: "Corre."

276. C1: "Corre."

277. C3: "Ema lá, a ema ali, oh" (a criança conduz o grupo a olhar a ema do recinto).

278. M: "Por que ela precisa dessa patona grandona?"

279. C1: "Para correr."

280. Cv: "Pra correr."

281. M: Quem acha que é correr, levanta a mão (ver quantos levantaram as mãos).

282. C1: pra se coçar também.

283. M: "Pra se coçar também, pode ser. Muito bem, quem falou que era para correr, era para correr mesmo. Ela corre muito. Uma coisa legal que ela tem é que, quando ela está correndo, sabe o que ela faz para poder virar? Alguém imagina?"

284. C1: "Freia." 
285. M: "O que ela faz para virar?"

286. C1: "Esticava o corpo.

287. M: "Que parte do corpo?"

288. C1: "Ombro."

289. M: "O ombro, A asa você está dizendo? Ela faz assim para poder virar?" (o monitor faz o movimento do corpo)

290. C1: "É."

291. M: "Muito bem! Mandou muito bem! Ela está correndo, correndo, correndo... Ela vai virar para cá, ela abre as asas e vira com tudo." (o monitor mostra com o corpo como a ave faz quando corre)

292. P: "E se ela virar sem abrir a asa?"

293. M: "Ela vai virar muito... serve igual... abriu, vai pegar um vento...com tudo."

294. C1: "O tio, que bicho é aquele ali atrás."

295. M: "Vocês querem dar uma olhada nele?"

296. C1: "Esqueci o nome dele, que tem a mão torta." (a criança está se referindo ao tamanduá).

4- Objeto biológico trabalhado: crânio de tamanduá-bandeira

297. SDR 12: M: “Atenção, turminha! Turminha vem cá! Que bicho será que é aquele?"

298. C1: "Tamanduá."

299. M: "Tamanduá, o que?"

300. Cv: "Bandeira."

301. M: "Tamanduá bandeira, muito bem! Gente vou pegar uma coisinha para vocês darem uma olhadinha. Pessoal, o que é isso?" (neste momento o monitor apresenta o crânio de tamanduá e até as crianças de outra escola que estão em frente ao recinto do tamanduá se interessam pelo objeto e começam a participar).

302. Cv: "Bico."

303. Cv: "É a cabeça dele."

304. C3: "É o focinho."

305. M: "Um bico? É um tucano para ter bico?"

306. C3: "Não, é o focinho dele."

307. Cv: "É a boca."

308. Cv: "A perna."

309. Cv: "A cocha."

310. M: "Gente, esse aqui é um crânio de tamanduá bandeira. Esse aqui é a cabeça dele. Vamos dar uma olhada no bicho lá. Olha a língua dele, olha a língua dele."

311. Cv: "Ele come formiga!"

312. C3: "Oh, tia aqui da para ele sair."

313. P: "Nossa quanto, é pelo aquilo de lá."

314. M: "Tudo é pelo."

315. P: "Quanto pelo! Ele precisa ir no barbeiro."

316. M: "Gente sabe aquela região que falei para vocês que ele mora a região de Cerrado. Que tem aqueles matos altos e é tem um monte de cupinzeiro?"

317. C1: "Tio que cheiro ruim."

318. M: "É o cheiro de coco esse daí, depois eu vou mostrar de quem que é ."

319. C3: "Ema..."

320. M. "Gente olha só o tamanduá... Primeiro, vou fazer uma pergunta. Quantos dentes têm o tamanduá?"

321. C1: "Vinte, mil,..." 
322. M: "Menos."

323. Cv: "Dez."

324. Cv: "Quatro."

325. M: "Quatro. Menos."

326. C1: "Quinze."

327. M: "Quinze. Menos."

328. C3: "Três."

329. M: "Menos."

330. Cv: "Dois."

331. M: "Dois? Menos."

332. Cv: "Um."

333. M: "Ai... erraram. Menos."

334. C: "Zero."

335. M: "Zero? Muito bem!"

336. P: "Então quantos deles ele tem?"

337. C1: "Não tem dente porque ele chupa."

338. M: "Eu falo que o tamanduá é igual ao avô da gente, não tem dente."

339. C3: "Ele faz assim oh..." (a criança mostra com a língua)

340. C1: "O tio, ele coloca a língua para catar?"

341. M: "O que, que ele come?"

342. Cv: "Formiga."

343. M: "Formiga, cupim."

344. C1: "Ele chupa."

345. M: "E olha só como ele faz... turminha."

346. C1: "O tio olha só como ele faz para catar." (a criança faz movimento com a sua língua para mostrar)

347. M: "É bem assim mesmo. Oh, o tamanduá ele tem uma língua grandona. Quem sabe quanto que mede a língua do tamanduá?"

348. P: "Quanto que mede uma língua."

349. C1: "Ah, vinte metros."

350. C3: "Dez metros."

351. M: "Dez metros? Menos. Não é em metros, é em centímetros."

352. C1: "Três."

353. M: "Três centímetros? Mais."

354. C3: "Um."

355. M: "Um? Mais."

356. Cv: "Vinte, quinze."

357. M: Vinte? Quinze?

358. Cv: "Dez. Oito. Cem."

359. M: "Cem metros ou cem centímetros? Menos?"

360. Cv: "Trinta."

361. M: "Trinta? Mais."

362. Cv: "Cinquenta."

363. M: "Cinquenta? Mais."

364. Cv: "Cinquenta mil, dez mil, setenta?"

365. M: "Setenta? Menos."

366. Cv: "Sessenta?"

367. M: "Sessenta? Sabe que o tamanduá tem 60 centímetros. Manda muito bem esse cara! A língua dele tem mais ou menos 70 centímetros. Sabe como é que é essa língua dele? Oh, ele tem que comer cupim e carrapato e fica lá no cupinzeiro.” 
368. C1: "Cupim e carrapato?"

369. M: "Carrapato, não! Cupim e formiga que está lá no cupinzeiro. Como é que tem que ser a língua dele?"

370. C1: "Grande."

371. M: "Grande e o que mais?"

372. C1: "Grosso."

373. M: "Grosso? Se não a formiga vai lá e morde? Mas como a formiga vai ficar pressa lá?"

374. C3: "Ele engole... Ele pega a língua dele..."

375. Cv: "Ele enrola".

376. C1: "Não.

377. M: "Mas como tem que ser essa língua?"

378. C1: "É um monte de, de grude, grude"

379. C3: "Ela é enroladinha."

380. M: "Grude, grude, muito bem! A língua dele é gosmenta. Tem tipo de uma cola, sabe para que? Para ele poder catar (a professora ri de satisfação e o monitor imita o tamanduá comendo colocando o crânio em contato com o seu braço, supondo que esse seja o cupinzeiro)".

381. P: "Se eu puser só o meu dedo, assim não vem nada."

382. M: "Não vem nada. Ele vem cheio de cuspe (o monitor faz o barulho com a boca) põe lá no cupinzeiro..."

383. P: "O que acontece com as formiguinhas... gruda tudo na língua dele?"

384. M: "Gruda ele vai lá e come."

385. P: "Que delícia."

386. M: "Ele come o dia inteiro."

387. C: "Ele fica assim oh..."

388. C3: "Ala, dois, o macho e a fêmea."

389. M: "Alá, o olho dele o olho dele é pequininho e a visão dele não é muito boa."

390. C3. "O tio esta parte aqui parece a parte do rabo dele."

391. M: "E a visão dele não é muito boa, mas sabe uma coisa que ele tem que é super bom?"

392. C1: "É o nariz."

393. M: "Que é bem melhor que o nosso? É o nariz. Olhe o tamanho do narigão dele.

Sabe para que, que serve?"

394. C3: "Para cheirar melhor."

395. C1: "Que nem..."

396. P: "Pra cheirar melhor..." (a professora imita a criança)

397. M: "E pra que serve o narigão grandão?"

398. Cv: "Para cheirar a ..."

399. C3: "Ah ele sente o cheiro da formiga."

400. M: "Não só das formigas de algum predador que queira caçar ele, alguma coisa."

401. (nesse momento os tamanduás se mexem e uma das crianças vê e chama a atenção de todos que vão observar os animais)

402. C: "Mais um."

403. C: "O tio tem filhote."

404. M: "Olha lá ta deitado que folgadão."

405. C: "Olha, outro."

406. C: "O pé dele!"

407. P: "Alá, que delícia deitado de cabeça para cima."

408. M: "Ele ta mostrando a língua para fora." 
409. C1: "O tio vamos lá para olha."

410. C3: "Alá o outro ta fazendo cocô."

411. C: "É ele ta fazendo cocô."

412. P: "Ala, ele deitado... que lindo!".

413. C: 'O tio eles tem filhote?"

414. M: "Tem aqui no zoológico e teve filhote um tempo atrás".

415. SDR 13: M: "Oh, eu vou passar... Vocês vão passando para o amiguinho." (neste momento o monitor passa o crânio do tamanduá para manuseio).

416. Cv: "Eu não quero ver não." (um grupo de crianças continua olhando os animais e o outro vai manusear o crânio do tamanduá)

417. C2: "Eu quero."

418. C1: "Que beijinho dorme dorme...da para mim depois..."

419. C4: "Alá, a linguona dele, tia.

420. C1: "Dá pra mim depois."

421. C3: "Alá, a gosmenta dele.".

422. C2: "É para ele."

423. C1: "É pra mim, porque aquela hora foi assim."

424. M: "Pessoal, olha só! O pelo é bem grosso, não é? Dá uma olhada no pelo dele. Quando pega fogo na floresta, que alguém joga balão, o balão cai na floresta, ou alguém bota fogo na mata, o que será que acontece com este tamanduá?".

425. C1: "Aí queima a pele dele."

426. M: "Ele queima. Esse pelo dele é bem seco, se pegar fogo vai queimar, vai matar."

427. C1: "Cheira." (essa criança fala para a outra criança cheirar o crânio).

428. C2: "Deixa eu ver." (o monitor continua falando e algumas crianças não estão prestando atenção, pois estão interessadas no crânio).

429. M: "Então gente, muita gente solta balão. Então pede para as pessoas não soltarem balão, porque é muito perigoso e pode matar um monte de animal, inclusive o tamanduá bandeira.".

430. P: "Já seco olha direitinho e passa para outra pessoa". (a professora orienta as crianças para observar o crânio do tamanduá, enquanto eles estão andando em direção a outro animal que querem muito ver, o elefante).

\section{5- Objeto biológico trabalhado: crânio de onça}

431. SDR 14 P: “O que será que vai sair daí agora?” (a professora refere-se a mochila de curiosidades)

432. C1: "A tromba." (as crianças acham que é um objeto relacionado ao elefante que fica em um recinto em frente à onça).

433. Cv: "A boca".

434. Cv: "O elefante".

435. M: "Você acha que iria caber na minha mochilinha a boca do elefante? A boca do elefante é enorme".

436. C3: "Eu já sei a tromba".

437. C4: "É a pata".

438. P: “O que será isso hein?”(nesse momento monitor mostra o crânio da onça)

439. Cv: "É do Leão".

440. C2: “Ah, eu sei o que é isso daí, é aquela..." (a criança aponta para sua cabeça)

441. M: "É um crânio."

442. C3: "Ele morreu."

443. M: "Oh, todos os bichos que eu parei para mostrar para vocês são bichos brasileiros. Que bicho será que é esse daqui?” (o monitor aponta para o crânio da onça) 
444. C1: "Leão, onça."

445. M: "Leão é brasileiro?"

446. CI: "Da onça."

447. M: "Da onça, muito bem!

448. SDR 15: O que, que a onça come?"

449. C2: "Carne."

450. M: "Carne. Então esses dentes dela aqui servem para que?"

451. C2: "Para comer a carne."

452. C1: "Para morder."

453. M: "E esses dois dentões aqui da frente?"

454. C3 "Para morder."

455. M: "Os dentes nossos do fundo serve para o que? Os nossos."

456. Cv: "Para mastigar."

457. M: "Para mastigar, muito bem! Esses dentes como é que é? Ele é reto, num é?"

458. Cv: "É.".

459. M: "Esse dente aqui oh, como que ele é? O que, que tem aqui? Cheio de ponta, né? Para que, que serve esse dente aqui?"

460. SDR 16: C1: "Tio porque tem esse aqui..." (a criança aponta para a etiqueta de identificação da peça do museu).

461. M: "Tem marcação".

462. C1: "Marcação do homem que morreu, né."

463. M: "Não, marcação para saber que bicho que é..."

464. SDR 17: M: "Para que, que serve esses dentões todo cheio de ponta?"

465. P: "Pra que será?"

466. Cv: "Para ele poder pegar as coisas."

467. M: "Pegar, como assim?"

468. C3: "Pega e coloca a pata."

469. M: "O nosso também dá para pegar."

470. C3: "Tio, pegar, colocar a pata e puxar.".

471. M: "Dá para rasgar, segurar assim?" (o monitor mostra com as mãos).

472. C3: "É."

473. M: "Muito bem! Esse dentão dele aqui serve pra rasgar... se fosse pra morder pra poder matar o bicho... esse aqui oh, serve pra rasgar..."

474. C1: "O tio a gente vai ver agora, a gente vai catar." (a criança quer manusear o objeto).

475. M: "Oh, de todos os gatos que tem no mundo todo, a onça-pintada é o maior do Brasil. Vocês sabem que a onça é um gato? O leão também é um gato, o tigre também é um gato. Oh, o tigre é o maior gato do mundo."

476. C1: "Ele é famoso."

477. M: "É o do Brasil, o maior gato é a onça-pintada."

478. M: "Agora eu quero que todo mundo olha no dedo aqui, no seu dedo, olha no seu dedo polegar. Quem tem RG aqui? Levanta o dedo polegar. Quem tem RG não teve que colocar o dedo assim....carimbar o dedo."

479. Cv: "Ah...".

480. M: "Se você olha no dedo aqui agora, não tem um monte de risquinho nosso dedo? O nome disso aqui é impressão digital. Eu tenho uma, você tem uma, você tem outra."

481. C1: "Todo mundo tem."

482. C4: "Meu pai vai tirar meu RG." 
483. M: "Todo mundo tem, todas são diferentes, não tem nenhuma igual à outra. Todas as impressões digitais são diferentes. É gente, a onça-pintada tem impressão digital também. Dá uma olhadinha nela ali, só olha só para ela ali."

484. C1: "O tio eu não tô vendo ela."

485. M: "Olha ali."

486. C1: “Alá, ela lá oh...”.

487. M: "Tá vendo essas pintas do corpo dela?"

488. C1: É impressão digital.

489. M: "As pintas do corpo dela são iguais à impressão digital. Nenhuma pinta de onça é igual uma da outra."

490. M: "Vamos dar uma olhadinha lá (o monitor foi em frente ao recinto da onça). Olha só, olha só, olha só."

491. C3: "O tio não tem três onça?"

492. M: "Tem três a outra ta lá traz. Olha as pintas do corpo dela, vamos dar uma olhada nas pintas do corpo dela. É igual à outra que esta lá?"

493. C1: "Não."

494. M: "É parecida né, mas não é igual."

495. C3: "É diferente."

496. M: "Cada uma é de um jeito diferente, de um formato diferente."

497. C1: "O tio...".

498. M: "Quem aqui já viu a onça preta?"

499. C1: 'Eu."

500. CI: "Eu não."

501. M: "A Pantera negra?"

502. CI: "Eu."

503. M: "A pantera negra não é nada mais nada menos que uma onça pintada. É a mesma coisa, só que a diferença que ela é mais escura, ela é preta."

504. C1: "O tia, a pantera cor de rosa é um gato também?"

505. P: "É."

506. C1: "Existe?"

507. M: "Que vê oh? Vou fazer uma coisa... A Daniele não é bem branquinha?"

508. Cv: "É?"

509. M: "Eu não sou moreno?"

510. Cv: "É."

511. M: "Como é seu nome? “

512. C7: "Taís."

513. M: "A Taís também não é morena?"

514. Cv: "É."

515. M: "A gente tem cor diferente, não tem?"

516. Cv: "É."

517. M: "Mas a gente é bicho homem do mesmo jeito, não é verdade? É bicho homem. Você não é bicho? A gente é bicho homem."

518. P: "Nós não somos também animais?"

519. M: "A gente é animal também. Ai, ai, ai, como eu quero saber qual é a diferença?"

520. P: "Qual a diferença nossa com eles?"

521. C3: "A diferença é que ele...” (a criança se $\mathrm{C} 1$ não deixou a $\mathrm{C} 3$ terminar a fala).

522. C1: "A diferença é que eles são bichos e têm o negocinho no corpo inteiro".

523. M: "Não que a professora falou."

524. P: "Qual a diferença de um bicho assim e nós?"

525. C3: "Eu sei tia..." (novamente a criança $\mathrm{C} 1$ não deixou a $\mathrm{C} 3$ falar). 
526. C1: "É que nós somos humanos e eles são bichos".

527. P: "Nós somos bichos também."

528. C3. "O tio eu sei por que eles têm a pinta e a gente não..." (novamente esta criança não teve voz)

529. C3: "A gente também tem..."

530. C8: "Eu tenho aqui, oh".

531. M: "Pessoal, vou contar uma coisa para vocês".

532. C3: "O tio sabe a única coisa que a gente não viu aqui, a girafa?"

533. M: "Sabe por que a gente não viu a girafa aqui? Porque não tem girafa aqui".

534. Cv: Oh...

535. M: "Só em São Paulo, lá no Zoológico de São Paulo."

536. C1: "O tia a gente vai aparecer na TV. Nós vamos?"

537. SDR 18: M: "Oh pessoal, quem quiser segurar ela para passar a mão, vai poder (nesse momento as crianças manuseiam o crânio)".

538. C1: "Tio, o que é isso daqui?" (a criança aponta para uma parte no crânio da onça) 539. M: "Esse aqui... Esse é um ossinho que ..."

540. C1: "Que gruda." (a criança compara com o seu crânio e aponta para a sua nuca). 541. M: "É um ossinho que liga com o osso da sua a coluna. Sabe a coluna ela tem um monte de vértebras, e um monte de osso que encaixa certinho aqui e aqui fica o cérebro dele."

542. C1: "Cérebro, oh, vocês tiraram

543. M: "Tiraram tudo."

544. C1: "O tio mais o que você fez com o cérebro?"

545. M: "Olha que maldade! Como essa onça morreu! Ela tomou um tiro aqui e saiu aqui (o monitor mostra o furo de bala no crânio da onça). Tem gente que mata a onça porque a onça come o gado, aí o pessoal tá invadindo o terreno das onças, tão pegando floresta para colocar gado, aí as onças acabam comendo os gados das pessoas."

546. Cv: "Tiro!" (neste momento todas as crianças querem manusear o crânio, as crianças queriam saber mais sobre o tiro do crânio da onça)

547. C2: "Vai que ele morde seu dedo"

548. C8: "Tudo ela pergunta, né tio".

549. P: "Pra ela tirar dúvida, né".

550. SDR 19: M: “Gente vou fazer uma pergunta? Vocês têm um dente um canino assim? Esse daqui é um dente canino (o monitor aponta para o dente canino no crânio da onça). Vocês têm uma presa igual ao dele?"

551. Cv: "Ah, esse daqui?" (as crianças apontam para o seu dente canino)

552. M: "Qual? Deixa eu ver... Você não tem."

553. C3: "Não é o que caiu, o seu é os dois que caiu".

554. M: "Não, é esse daí mesmo. É igual ao dele. Alguém mais tem alguma pergunta?" 
Quadro 1: Descrição e análise dos materiais educativos do Zôo de Sorocaba

\begin{tabular}{|c|c|c|c|c|c|c|c|}
\hline $\begin{array}{c}\text { NOME DO } \\
\text { KIT }\end{array}$ & CONTEÚDO/CONCEITO & $\begin{array}{l}\text { INDICAÇÃO DE } \\
\text { QUANDO USAR }\end{array}$ & $\begin{array}{l}\text { INDICAÇÃO DE } \\
\text { COMO USAR }\end{array}$ & $\begin{array}{c}\text { ITENS QUE } \\
\text { COMPÕEM O KIT }\end{array}$ & DESCRIÇÃO & AUTORIA & \begin{tabular}{|c} 
INDICADORES E \\
ATRIBUTOS DE \\
AC \\
\end{tabular} \\
\hline $\begin{array}{l}\mathbf{P} \\
\mathbf{r} \\
\mathbf{a} \\
\mathbf{i} \\
\mathbf{a} \\
\\
\mathbf{A} \\
\mathbf{r} \\
\mathbf{e} \\
\mathbf{n} \\
\mathbf{0} \\
\mathbf{s} \\
\mathbf{a}\end{array}$ & $\begin{array}{l}\text { Importância do mar, movimento } \\
\text { das ondas, aspectos gerais dos } \\
\text { animais que compõem o kit, } \\
\text { curiosidades sobre as conchas, } \\
\text { classificação dos moluscos e } \\
\text { equinodermos, poluição marinha } \\
\text { causada pelo ser humano, } \\
\text { conservação. }\end{array}$ & \begin{tabular}{|l|} 
Sala de \\
aula/estudantes e \\
professores, aulas \\
de Ciências, \\
Biologia e Educação \\
Ambiental.
\end{tabular} & \begin{tabular}{|l|} 
Manual do professor, \\
nomeia a autoria do \\
material, explicita os \\
objetivos da criação do kit, \\
indica que o kit tem \\
animais e outros materiais, \\
solicita a leitura de todo o \\
manual e de observar a \\
posição de cada objeto na \\
caixa, sugere que exista \\
manipulação dos materiais, \\
chama a atenção para o \\
cuidado com os materiais.
\end{tabular} & $\begin{array}{l}\text { Animais em via seca: } \\
\text { estrela-do-mar, } \\
\text { marisco, rala-coco, } \\
\text { sapinhangá, ofiuróide, } \\
\text { borboleta (concha), } \\
\text { Strombus (concha), } \\
\text { Anadara (concha), } \\
\text { Olivancilaria (concha) } \\
\text {, Sanguinolaria } \\
\text { (concha). Animais em } \\
\text { via úmida: poliqueta, } \\
\text { camarão. Outros: } \\
\text { areia do mar, livros e } \\
\text { manual do professor. }\end{array}$ & \begin{tabular}{|l|} 
O kit é apresentado \\
em uma caixa \\
plástica grande com \\
etiquetas de \\
identificação na \\
tampa externa e nas \\
laterais. Na parte \\
interna da tampa \\
existe a lista de \\
materiais que \\
compõem o \\
conjunto. No seu \\
interior há uma pasta \\
contendo livros \\
sobre oceanos, \\
animais, mar, \\
preservação, vida \\
nos oceanos, manual \\
do professor e \\
folheto de orientação \\
para montagem de \\
aquário marinho. Os \\
animais em via \\
úmida estão \\
abrigados em dois \\
frascos de vidro e os \\
em via seca em 11 \\
potes plásticos.
\end{tabular} & \begin{tabular}{|l} 
Equipe de \\
educação \\
ambiental do \\
zoológico.
\end{tabular} & $\begin{array}{l}1 \mathrm{a}, 2 \mathrm{c}, 2 \mathrm{~d}, 2 \mathrm{e}, 3 \mathrm{a} \\
4 \mathrm{a}, 4 \mathrm{~b}, 4 \mathrm{c}\end{array}$ \\
\hline
\end{tabular}




\begin{tabular}{|c|c|c|c|c|c|c|c|}
\hline $\begin{array}{l}\text { NOME DO } \\
\text { KIT }\end{array}$ & CONTEÚDO/CONCEITO & $\begin{array}{l}\text { INDICAÇÃO DE } \\
\text { QUANDO USAR }\end{array}$ & $\begin{array}{l}\text { INDICAÇÃO DE } \\
\text { COMO USAR }\end{array}$ & $\begin{array}{c}\text { ITENS QUE } \\
\text { COMPÕEM O KIT }\end{array}$ & DESCRIÇÃO & AUTORIA & $\begin{array}{c}\text { INDICADORES E } \\
\text { ATRIBUTOS DE } \\
\text { AC }\end{array}$ \\
\hline $\begin{array}{l}\mathbf{C} \\
\mathbf{0} \\
\mathbf{s} \\
\mathbf{t} \\
\tilde{\mathbf{a}} \\
\mathbf{0} \\
\mathbf{R} \\
\mathbf{R} \\
\mathbf{0} \\
\mathbf{c} \\
\mathbf{h} \\
\mathbf{0} \\
\mathbf{s} \\
\mathbf{0}\end{array}$ & $\begin{array}{l}\text { Definição de costão rochoso, } \\
\text { divisão de um costão, } \\
\text { caracterização das faixas, } \\
\text { características dos animais } \\
\text { presentes no kit, características do } \\
\text { litoral, vida no mar. }\end{array}$ & \begin{tabular}{|l|} 
Sala de \\
aula/estudantes e \\
professores, aulas \\
de Ciências, \\
Biologia e Educação \\
Ambiental.
\end{tabular} & \begin{tabular}{|l|} 
Manual do professor, \\
nomeia a autoria do \\
material, explicita os \\
objetivos da criação do kit, \\
indica que o kit tem \\
animais e outros materiais, \\
solicita a leitura de todo o \\
manual e de observar a \\
posição de cada objeto na \\
caixa, sugere que exista \\
manipulação dos materiais, \\
chama a atenção para o \\
cuidado com os materiais. \\
\end{tabular} & $\begin{array}{l}\text { Organismos em via } \\
\text { úmida: caranguejo- } \\
\text { vermelho, lula, lírio- } \\
\text { do-mar, anêmona, alga } \\
\text { parda (Sargassum), } \\
\text { alga verde. } \\
\text { Organismos em via } \\
\text { seca: barata-da-praia, } \\
\text { alga parda, rosquinha, } \\
\text { coral chifre-de-veado, } \\
\text { coral cérebro, esponja, } \\
\text { ouriço-do-mar, } \\
\text { ermitão, mexilhão, } \\
\text { calistoma, thais, } \\
\text { cracas. Outros: livros } \\
\text { e manual do professor. } \\
\end{array}$ & \begin{tabular}{|l|} 
O kit é apresentado \\
em uma caixa \\
plástica grande com \\
etiquetas de \\
identificação na \\
tampa externa e nas \\
laterais. Na parte \\
interna da tampa \\
existe a lista de \\
materiais que o \\
compõe. No seu \\
interior existe uma \\
pasta com o manual \\
do professor e cinco \\
livros tratando do \\
tema do kit. Os \\
animais estão \\
abrigados em nove \\
caixas plásticas \\
menores e 9 frascos \\
de vidro.
\end{tabular} & \begin{tabular}{|l} 
Equipe de \\
educação \\
ambiental do \\
zoológico.
\end{tabular} & $\begin{array}{l}\text { 1a, 2d, 2e, 3a, 4a, } \\
4 \mathrm{~b}, 4 \mathrm{c} .\end{array}$ \\
\hline
\end{tabular}




\begin{tabular}{|c|c|c|c|c|c|c|c|}
\hline $\begin{array}{l}\text { NOME DO } \\
\text { KIT }\end{array}$ & CONTEÚDO/CONCEITO & $\begin{array}{l}\text { INDICAÇÃO DE } \\
\text { QUANDO USAR }\end{array}$ & $\begin{array}{l}\text { INDICAÇÃO DE } \\
\text { COMO USAR }\end{array}$ & $\begin{array}{c}\text { ITENS QUE } \\
\text { COMPÕEM O KIT }\end{array}$ & DESCRIÇÃO & AUTORIA & \begin{tabular}{|c} 
INDICADORES E \\
ATRIBUTOS DE \\
AC
\end{tabular} \\
\hline $\begin{array}{ll}\mathbf{P} & \\
\mathbf{e} & \\
\mathbf{i} & \mathbf{S} \\
\mathbf{x} & \mathbf{o} \\
\mathbf{e} & \mathbf{r} \\
\mathbf{s} & \mathbf{o} \\
& \mathbf{c} \\
\mathbf{d} & \mathbf{a} \\
\mathbf{o} & \mathbf{b} \\
& \mathbf{R} \\
\mathbf{R} & \mathbf{a} \\
\mathbf{i} & \\
\mathbf{o} & \end{array}$ & \begin{tabular}{|l|} 
Diversidade, classificação e \\
características gerais dos peixes, \\
informações sobre o Rio Sorocaba, \\
características dos peixes do Rio \\
Sorocaba presentes no kit, peixes \\
como alimento, poluição, \\
curiosidades sobre peixes.
\end{tabular} & \begin{tabular}{|l} 
Sala de \\
aula/estudantes e \\
professores, aulas \\
de Ciências, \\
Biologia e Educação \\
Ambiental.
\end{tabular} & $\begin{array}{l}\text { Manual do professor, } \\
\text { nomeia a autoria do } \\
\text { material, explicita os } \\
\text { objetivos da criação do kit, } \\
\text { indica que o kit tem } \\
\text { animais e outros materiais, } \\
\text { solicita a leitura de todo o } \\
\text { manual e de observar a } \\
\text { posição de cada objeto na } \\
\text { caixa, sugere que exista } \\
\text { manipulação dos materiais, } \\
\text { chama a atenção para o } \\
\text { cuidado com os materiais. }\end{array}$ & $\begin{array}{l}\text { Outros: Manual do } \\
\text { professor. Animais } \\
\text { em via úmida: } \\
\text { caborja, pirambeba, } \\
\text { cascudo, canivete, } \\
\text { lambari, coridora, } \\
\text { traíra, peixe-cadela. } \\
\end{array}$ & $\begin{array}{l}\text { O kit é apresentado } \\
\text { em uma caixa } \\
\text { plástica grande com } \\
\text { etiquetas de } \\
\text { identificação na } \\
\text { tampa e nas laterais, } \\
\text { na parte interna da } \\
\text { tampá tem a lista do } \\
\text { material do kit. } \\
\text { Existem oito } \\
\text { espécies de peixes } \\
\text { do Rio Sorocaba } \\
\text { acondicionadas em } \\
\text { frascos de vidro com } \\
\text { álcool. }\end{array}$ & \begin{tabular}{|l|} 
Equipe de \\
educação \\
ambiental do \\
zoológico.
\end{tabular} & $\begin{array}{l}\text { 1a, 2d, 2e, 3a, 4a, } \\
4 \mathrm{~b}, 4 \mathrm{c}\end{array}$ \\
\hline
\end{tabular}




\begin{tabular}{|c|c|c|c|c|c|c|c|}
\hline $\begin{array}{l}\text { NOME DO } \\
\text { KIT }\end{array}$ & CONTEÚDO/CONCEITO & $\begin{array}{l}\text { INDICAÇÃO DE } \\
\text { QUANDO USAR }\end{array}$ & $\begin{array}{l}\text { INDICAÇÃO DE } \\
\text { COMO USAR }\end{array}$ & $\begin{array}{c}\text { ITENS QUE } \\
\text { COMPÕEM O KIT }\end{array}$ & DESCRIÇÃO & AUTORIA & $\begin{array}{c}\text { INDICADORES E } \\
\text { ATRIBUTOS DE } \\
\text { AC }\end{array}$ \\
\hline $\begin{array}{l}\text { D } \\
\text { e } \\
\text { f } \\
\text { e } \\
\text { s } \\
\text { a }\end{array}$ & $\begin{array}{l}\text { Adaptações dos animais e } \\
\text { mecanismos de defesa. }\end{array}$ & \begin{tabular}{|l|} 
Sala de \\
aula/estudantes e \\
professores, aulas \\
de Ciências, \\
Biologia e Educação \\
Ambiental. \\
\end{tabular} & $\begin{array}{l}\text { Manual do professor, } \\
\text { nomeia a autoria do } \\
\text { material, explicita os } \\
\text { objetivos da criação do kit, } \\
\text { indica que o kit tem } \\
\text { animais e outros materiais, } \\
\text { solicita a leitura de todo o } \\
\text { manual e de observar a } \\
\text { posição de cada objeto na } \\
\text { caixa, sugere que exista } \\
\text { manipulação dos materiais, } \\
\text { chama a atenção para o } \\
\text { cuidado com os materiais. }\end{array}$ & \begin{tabular}{|l|} 
Animais em via \\
úmida: serpente- \\
dormideira e calango- \\
das-pedras. Animais \\
em via seca: bicho- \\
pau, taturanas, filhote \\
de tatu-galinha e de \\
jabuti taxidermizados, \\
concha. Partes de \\
animais: ferrão de \\
arraia, espinhos de \\
ouriço, crânio de \\
cascavel, espinhos de \\
porco-espinho. \\
Outros: manual para \\
o professor e joaninha \\
de pelúcia.
\end{tabular} & \begin{tabular}{|l} 
O kit é apresentado \\
em uma caixa \\
plástica grande com \\
etiquetas de \\
identificação na \\
tampa e nas laterais, \\
na parte interna da \\
tampa tem a lista do \\
material do kit. O \\
conjunto contém \\
partes de animais \\
referentes à defesa, \\
esconderijo, disfarce, \\
aposematismo e \\
manual do professor \\
com conteúdo \\
temático e com \\
algumas orientações \\
de uso do material.
\end{tabular} & $\begin{array}{l}\text { Equipe de } \\
\text { educação } \\
\text { ambiental do } \\
\text { zoológico. }\end{array}$ & $\begin{array}{l}\text { 1a, } 2 \mathrm{~d}, 2 \mathrm{e}, 3 \mathrm{a}, 4 \mathrm{a}, \\
4 \mathrm{~b}, 4 \mathrm{c} .\end{array}$ \\
\hline
\end{tabular}




\begin{tabular}{|c|c|c|c|c|c|c|c|}
\hline $\begin{array}{l}\text { NOME DO } \\
\text { KIT }\end{array}$ & CONTEÚDO/CONCEITO & $\begin{array}{l}\text { INDICAÇÃO DE } \\
\text { QUANDO USAR }\end{array}$ & $\begin{array}{l}\text { INDICAÇÃO DE } \\
\text { COMO USAR }\end{array}$ & $\begin{array}{c}\text { ITENS QUE } \\
\text { COMPÕEM O KIT }\end{array}$ & DESCRIÇÃO & AUTORIA & \begin{tabular}{|c} 
INDICADORES E \\
ATRIBUTOS DE \\
AC
\end{tabular} \\
\hline $\begin{array}{c}\mathbf{A} \\
\mathbf{l} \\
\mathbf{i} \\
\mathbf{m} \\
\mathbf{e} \\
\mathbf{n} \\
\mathbf{t} \\
\mathbf{a} \\
\mathbf{c} \\
\tilde{\mathbf{a}} \\
\mathbf{0}\end{array}$ & \begin{tabular}{|l|} 
Adaptações nos animais, \\
alimentação, tipos de dentes, \\
dentição nos vários grupos animais \\
presentes no kit, outros tipos de \\
estruturas para triturar alimentos, \\
curiosidades sobre as vacas, falta \\
de dentes nas aves, evolução, \\
ancestral das aves.
\end{tabular} & \begin{tabular}{|l|} 
Sala de \\
aula/estudantes e \\
professores, aulas \\
de Ciências, \\
Biologia e Educação \\
Ambiental. \\
\\
\end{tabular} & $\begin{array}{l}\text { Manual do professor, } \\
\text { nomeia a autoria do } \\
\text { material, explicita os } \\
\text { objetivos da criação do kit, } \\
\text { indica que o kit tem } \\
\text { animais e outros materiais, } \\
\text { solicita a leitura de todo o } \\
\text { manual e de observar a } \\
\text { posição de cada objeto na } \\
\text { caixa, sugere que exista } \\
\text { manipulação dos materiais, } \\
\text { chama a atenção para o } \\
\text { cuidado com os materiais. }\end{array}$ & $\begin{array}{l}\text { Animais em via seca: } \\
\text { estrela-do-mar. Partes } \\
\text { de animais em via } \\
\text { seca: arcada de } \\
\text { tubarão, crânio de } \\
\text { cutia, crânio de bugio, } \\
\text { dentadura artificial } \\
\text { humana, } 3 \text { dentes de } \\
\text { onça, crânio de mão- } \\
\text { pelada, crânio de } \\
\text { tamanduá-mirim, } \\
\text { mandíbula de arraia, } \\
\text { crânio de papagaio, } \\
\text { crânio de flamingo, } \\
\text { crânio de ganso, } \\
\text { crânio de gaviãozinho, } \\
\text { crânio de cisne, } \\
\text { cabeça de socó, } \\
\text { cabeça de tucano. } \\
\text { Outros: manual para } \\
\text { o professor. }\end{array}$ & \begin{tabular}{|l|} 
O kit está abrigado \\
em uma caixa grande \\
identificado na \\
tampa e na lateral. \\
No interior da tampa \\
há uma lista com o \\
material que o \\
forma. Este kit \\
contém partes de \\
animais referentes à \\
alimentação. \\
Algumas peças \\
menores estão \\
abrigadas em frascos \\
plásticos. O manual \\
para o professor \\
contém dados de \\
biologia, aspectos da \\
fisiologia da \\
alimentação e \\
orientações de uso \\
do material.
\end{tabular} & \begin{tabular}{|l} 
Equipe de \\
educação \\
ambiental do \\
zoológico. \\
\\
\end{tabular} & $\begin{array}{l}1 \mathrm{a}, 2 \mathrm{e}, 3 \mathrm{a}, 4 \mathrm{a}, 4 \mathrm{~b} \\
4 \mathrm{c} .\end{array}$ \\
\hline
\end{tabular}




\begin{tabular}{|c|c|c|c|c|c|c|c|}
\hline $\begin{array}{c}\text { NOME DO } \\
\text { KIT }\end{array}$ & CONTEÚDO/CONCEITO & $\begin{array}{l}\text { INDICAÇÃO DE } \\
\text { QUANDO USAR }\end{array}$ & $\begin{array}{l}\text { INDICAÇÃO DE } \\
\text { COMO USAR }\end{array}$ & $\begin{array}{c}\text { ITENS QUE } \\
\text { COMPÕEM O KIT }\end{array}$ & DESCRIÇÃO & AUTORIA & $\begin{array}{c}\text { INDICADORES E } \\
\text { ATRIBUTOS DE } \\
\text { AC }\end{array}$ \\
\hline $\begin{array}{l}\text { A } \\
\text { n } \\
\text { f } \\
\text { í } \\
\text { b } \\
\mathbf{i} \\
\text { o } \\
\text { s }\end{array}$ & \begin{tabular}{|l|} 
Características dos anfíbios, \\
principais grupos de anfíbios, \\
membranas interdigitais da rã, \\
conservação, curiosidades e \\
diversidade de anfíbios, \\
reprodução, cuidado parental, \\
corte, equilíbrio ambiental e \\
anfíbios, alimentação, \\
classificação, anfíbios perigosos ao \\
homem.
\end{tabular} & Não há indicação & $\begin{array}{l}\text { Manual do professor, } \\
\text { nomeia a autoria do } \\
\text { material, explicita os } \\
\text { objetivos da criação do kit, } \\
\text { indica que o kit tem } \\
\text { animais e outros materiais, } \\
\text { solicita a leitura de todo o } \\
\text { manual e de observar a } \\
\text { posição de cada objeto na } \\
\text { caixa, sugere que exista } \\
\text { manipulação dos materiais, } \\
\text { chama a atenção para o } \\
\text { cuidado com os materiais. }\end{array}$ & $\begin{array}{l}\text { Animais em via } \\
\text { úmida: cobra-cega, } \\
\text { sapo cururu, sapo- } \\
\text { ferreiro, rã-do- } \\
\text { cerrado, sapo-de-cruz, } \\
\text { rã-paulistinha, } \\
\text { perereca minuta. } \\
\text { Outros: pranchas com } \\
\text { imagens da } \\
\text { diversidade de } \\
\text { anfíbios, DVDs com } \\
\text { imagens e conteúdo } \\
\text { biológico sobre o } \\
\text { tema, caixa plástica } \\
\text { com modelos de } \\
\text { animais de plástico, } \\
\text { manual para o } \\
\text { professor, jogo de } \\
\text { tabuleiro, folhas de } \\
\text { sulfite com letras de } \\
\text { músicas e curiosidades } \\
\text { sobre anfíbios. } \\
\end{array}$ & \begin{tabular}{|l} 
O kit está abrigado \\
numa caixa grande \\
etiquetada na tampa \\
externa e laterais. na \\
parte interna da \\
tampa encontra-se a \\
lista do conteúdo. O \\
conjunto de \\
materiais é formado \\
por uma pasta com \\
manual do professor, \\
jogo de tabuleiro, \\
DVDs com imagens \\
de anfíbios e \\
conteúdo biológico \\
sobre o grupo, folhas \\
de sulfite soltas com \\
curiosidade sobre \\
anfíbios e letras de \\
músicas sobre o tema \\
e caixa plástica com \\
modelos plásticos de \\
anfíbios e animais \\
originais.
\end{tabular} & $\begin{array}{l}\text { Não há } \\
\text { indicação }\end{array}$ & $\begin{array}{l}\text { 1a, 2d, 2e, 3a, 4a, } \\
4 \mathrm{~b}, 4 \mathrm{c} .\end{array}$ \\
\hline
\end{tabular}




\begin{tabular}{|c|c|c|c|c|c|c|c|}
\hline $\begin{array}{l}\text { NOME DO } \\
\text { KIT }\end{array}$ & CONTEÚDO/CONCEITO & $\begin{array}{l}\text { INDICAÇÃO DE } \\
\text { QUANDO USAR }\end{array}$ & $\begin{array}{l}\text { INDICAÇÃO DE } \\
\text { COMO USAR }\end{array}$ & $\begin{array}{c}\text { ITENS QUE } \\
\text { COMPÕEM O KIT }\end{array}$ & DESCRIÇÃO & AUTORIA & $\begin{array}{c}\text { INDICADORES E } \\
\text { ATRIBUTOS DE } \\
\text { AC }\end{array}$ \\
\hline $\begin{array}{l}\mathbf{D} \\
\mathbf{i} \\
\mathbf{n} \\
\mathbf{0} \\
\mathbf{s} \\
\mathbf{s} \\
\mathbf{a} \\
\mathbf{u} \\
\mathbf{r} \\
\mathbf{o} \\
\mathbf{s}\end{array}$ & $\begin{array}{l}\text { Vida e comportamento de alguns } \\
\text { dinossauros, conceito de fósseis, } \\
\text { formação dos fósseis, origem e } \\
\text { evolução dos animais, conteúdo } \\
\text { sobre as réplicas da caixa, tabela } \\
\text { do tempo geológico. }\end{array}$ & Não há indicação & $\begin{array}{l}\text { Sugestões de exercícios de } \\
\text { observação das réplicas, } \\
\text { indicação das réplicas } \\
\text { relacionadas ao conteúdo } \\
\text { do manual do professor. } \\
\\
\end{array}$ & $\begin{array}{l}\text { Réplicas de fósseis: } \\
\text { coral rugoso, garra de } \\
\text { oviraptor, plantas, } \\
\text { equinoderma, placa de } \\
\text { gliptodonte, tubos de } \\
\text { poliquetas, amonóide, } \\
\text { dente de tubarão. } \\
\text { Outros: coleções } \\
\text { sobre dinossauros de } \\
\text { bancas de jornal, } \\
\text { quebra-cabeça do } T \text {. } \\
\text { rex, pôster de } \\
\text { dinossauros, apostila } \\
\text { do Instituto de } \\
\text { Geociências da USP e } \\
\text { livros sobre } \\
\text { dinossauros. }\end{array}$ & \begin{tabular}{|l|} 
O kit está abrigado \\
numa caixa grande \\
etiquetada na tampa \\
externa e laterais. Na \\
parte interna da \\
tampa encontra-se a \\
lista do conteúdo. \\
Contém coleções \\
sobre dinossauros \\
lançadas em bancas \\
de jornal, pôster com \\
a genealogia dos \\
dinossauros, apostila \\
do Instituto de \\
Geociências da USP. \\
Não há manual do \\
professor. Contém \\
peças plásticas para \\
montagem do T. rex \\
e réplicas da oficina \\
de réplicas do \\
Instituto de \\
Geociências da USP. \\
As réplicas estão \\
abrigadas nas \\
embalagens \\
originais.
\end{tabular} & \begin{tabular}{|l|} 
Equipe de \\
educação \\
ambiental do \\
zoológico com \\
material do \\
Instituto de \\
Geociências da \\
USP. \\
\\
\\
\end{tabular} & $\begin{array}{l}1 \mathrm{a}, 2 \mathrm{~d}, 2 \mathrm{e}, 3 \mathrm{a}, 4 \mathrm{a} \\
4 \mathrm{~b}, 4 \mathrm{c}\end{array}$ \\
\hline
\end{tabular}




\begin{tabular}{|c|c|c|c|c|c|c|c|}
\hline $\begin{array}{l}\text { NOME DO } \\
\text { KIT }\end{array}$ & CONTEÚDO/CONCEITO & $\begin{array}{l}\text { INDICAÇÃO DE } \\
\text { QUANDO USAR }\end{array}$ & $\begin{array}{l}\text { INDICAÇÃO DE } \\
\text { COMO USAR }\end{array}$ & $\begin{array}{c}\text { ITENS QUE } \\
\text { COMPÕEM O KIT }\end{array}$ & DESCRIÇÃO & AUTORIA & $\begin{array}{c}\text { INDICADORES E } \\
\text { ATRIBUTOS DE } \\
\text { AC }\end{array}$ \\
\hline $\begin{array}{c}\text { M } \\
\mathbf{a} \\
\mathbf{m} \\
\mathbf{1} \\
\mathbf{f} \\
\mathbf{e} \\
\mathbf{r} \\
\mathbf{0} \\
\mathbf{s} \\
\mathbf{I}\end{array}$ & $\begin{array}{l}\text { Características gerais dos } \\
\text { mamíferos, informações sobre os } \\
\text { grupos que compõem o kit, } \\
\text { extinção, legislação sobre fauna, } \\
\text { lista de mamíferos ameaçados. }\end{array}$ & \begin{tabular}{|l|} 
Sala de \\
aula/estudantes e \\
professores, aulas \\
de Ciências, \\
Biologia e Educação \\
Ambiental.
\end{tabular} & $\begin{array}{l}\text { Manual do professor, } \\
\text { nomeia a autoria do } \\
\text { material, explicita os } \\
\text { objetivos da criação do kit, } \\
\text { indica que o kit tem } \\
\text { animais e outros materiais, } \\
\text { solicita a leitura de todo o } \\
\text { manual e de observar a } \\
\text { posição de cada objeto na } \\
\text { caixa, sugere que exista } \\
\text { manipulação dos materiais, } \\
\text { chama a atenção para o } \\
\text { cuidado com os materiais. }\end{array}$ & \begin{tabular}{|l|} 
Animais em via \\
úmida: feto de veado, \\
morcego-de-cara- \\
branca, morcego- \\
cauda-de-rato. Partes \\
de animais em via \\
seca: casco de tatu, \\
crânio de tamanduá- \\
bandeira, crânio de \\
golfinho, crânio de \\
veado, chifre de \\
veado. \\
Moldes de pegadas: \\
anta e veado. \\
Outros: manual para \\
o professor e dois \\
livros infantis sobre \\
tamanduá e mamíferos \\
em geral.
\end{tabular} & \begin{tabular}{|l|} 
Os materiais estão \\
abrigados em caixa \\
plástica grande \\
identificada na \\
tampa e na lateral, \\
em seu interior existe \\
uma lista com o \\
conteúdo do kit. O \\
kit é composto de \\
uma pasta com livros \\
(tamanduá e \\
mamíferos), três \\
frascos com material \\
em álcool, caixa com \\
modelos de pegadas, \\
estruturas animais \\
em via seca.
\end{tabular} & \begin{tabular}{|l} 
Equipe de \\
educação \\
ambiental do \\
zoológico. \\
\\
\end{tabular} & $\begin{array}{l}\text { 1a, 2a, 2b, 2d, 2e, } \\
\text { 3a 4a, 4b, 4c. }\end{array}$ \\
\hline
\end{tabular}




\begin{tabular}{|c|c|c|c|c|c|c|c|}
\hline $\begin{array}{l}\text { NOME DO } \\
\text { KIT }\end{array}$ & CONTEÚDO/CONCEITO & $\begin{array}{l}\text { INDICAÇÃO DE } \\
\text { QUANDO USAR }\end{array}$ & $\begin{array}{l}\text { INDICAÇÃO DE } \\
\text { COMO USAR }\end{array}$ & $\begin{array}{c}\text { ITENS QUE } \\
\text { COMPÕEM O KIT }\end{array}$ & DESCRIÇÃO & AUTORIA & $\begin{array}{c}\text { INDICADORES E } \\
\text { ATRIBUTOS DE } \\
\text { AC }\end{array}$ \\
\hline $\begin{array}{l}\text { M } \\
\mathbf{a} \\
\mathbf{m} \\
\mathbf{i} \\
\mathbf{f} \\
\mathrm{e} \\
\mathbf{r} \\
\mathbf{o} \\
\mathbf{s} \\
\mathbf{I} \\
\mathbf{I}\end{array}$ & $\begin{array}{l}\text { Características gerais dos } \\
\text { mamíferos, informações sobre os } \\
\text { grupos que compõem o kit, } \\
\text { extinção, legislação sobre fauna, } \\
\text { lista de mamíferos ameaçados }\end{array}$ & \begin{tabular}{|l|} 
Sala de \\
aula/estudantes e \\
professores, aulas \\
de Ciências, \\
Biologia e Educação \\
Ambiental. \\
\\
\end{tabular} & \begin{tabular}{|l|} 
Manual do professor, \\
nomeia a autoria do \\
material, explicita os \\
objetivos da criação do kit, \\
indica que o kit tem \\
animais e outros materiais, \\
solicita a leitura de todo o \\
manual e de observar a \\
posição de cada objeto na \\
caixa, sugere que exista \\
manipulação dos materiais, \\
chama a atenção para o \\
cuidado com os materiais.
\end{tabular} & \begin{tabular}{|l|} 
Parte de animais em \\
via seco: crânio de \\
leão, crânio de \\
cachorro-do-mato, \\
crânio de bugio, \\
crânio de sagui-do- \\
tufo-branco, espinhos \\
de ouriço. Moldes de \\
pegadas: mão-pelada \\
e gato-do-mato. \\
Outros: manual para o \\
professor.
\end{tabular} & $\begin{array}{l}\text { O kit é apresentado } \\
\text { em uma caixa } \\
\text { plástica grande com } \\
\text { etiquetas de } \\
\text { identificação na } \\
\text { tampa externa e nas } \\
\text { laterais com uma } \\
\text { lista de seu conteúdo } \\
\text { no interior. O kit é } \\
\text { composto de crânios } \\
\text { em via seca } \\
\text { abrigados em uma } \\
\text { caixa plástica menor } \\
\text { e numerados para } \\
\text { identificação na } \\
\text { apostila. Existe um } \\
\text { vidro pequeno } \\
\text { numerado e } \\
\text { identificado com } \\
\text { espinhos de ouriço e } \\
\text { dois moldes de } \\
\text { pegadas. }\end{array}$ & \begin{tabular}{|l} 
Equipe de \\
educação \\
ambiental do \\
zoológico.
\end{tabular} & $\begin{array}{l}1 \mathrm{a}, 2 \mathrm{a}, 2 \mathrm{~b}, 2 \mathrm{~d}, 2 \mathrm{e} \\
3 \mathrm{a} 4 \mathrm{a}, 4 \mathrm{~b}, 4 \mathrm{c}\end{array}$ \\
\hline
\end{tabular}




\begin{tabular}{|c|c|c|c|c|c|c|c|}
\hline $\begin{array}{l}\text { NOME DO } \\
\text { KIT }\end{array}$ & CONTEÚDO/CONCEITO & $\begin{array}{l}\text { INDICAÇÃO DE } \\
\text { QUANDO USAR }\end{array}$ & $\begin{array}{l}\text { INDICAÇÃO DE } \\
\text { COMO USAR }\end{array}$ & $\begin{array}{c}\text { ITENS QUE } \\
\text { COMPÕEM O KIT }\end{array}$ & DESCRIÇÃO & AUTORIA & $\begin{array}{c}\text { INDICADORES E } \\
\text { ATRIBUTOS DE } \\
\text { AC }\end{array}$ \\
\hline $\begin{array}{l}\text { R } \\
\text { é } \\
\mathbf{p} \\
\mathbf{t} \\
\mathbf{e} \\
\mathbf{i} \\
\mathbf{s} \\
\mathbf{I} \\
\mathbf{I}\end{array}$ & $\begin{array}{l}\text { Informações gerais sobre répteis, } \\
\text { grupo squamata (lagartos, } \\
\text { lagartixas e serpentes), } \\
\text { aprofundamento no grupo das } \\
\text { serpentes, identificação de uma } \\
\text { serpente peçonhentos, acidentes } \\
\text { com serpentes peçonhentas, } \\
\text { espécies de répteis em extinção, } \\
\text { conservação de répteis, } \\
\text { informações e curiosidades sobre } \\
\text { répteis. }\end{array}$ & \begin{tabular}{|l|} 
Sala de \\
aula/estudantes e \\
professores, aulas \\
de Ciências, \\
Biologia e Educação \\
Ambiental. \\
\\
\\
\end{tabular} & $\begin{array}{l}\text { Manual do professor, } \\
\text { nomeia a autoria do } \\
\text { material, explicita os } \\
\text { objetivos da criação do kit, } \\
\text { indica que o kit tem } \\
\text { animais e outros materiais, } \\
\text { solicita a leitura de todo o } \\
\text { manual e de observar a } \\
\text { posição de cada objeto na } \\
\text { caixa, sugere que exista } \\
\text { manipulação dos materiais, } \\
\text { chama a atenção para o } \\
\text { cuidado com os materiais. }\end{array}$ & \begin{tabular}{|l} 
Animais em via \\
úmida: lagarto, cobra- \\
de-duas-cabeças, \\
cobra-dormideira, \\
jararaca com bicefalia, \\
falsa coral. Partes de \\
animais em via \\
úmida: órgão genital \\
de cascavel, ovos de \\
serpente. Animais em \\
via seca: peles de \\
lagarto e serpente, \\
costela e vértebras de \\
serpente. Modelos: 2 \\
modelos de cabeça de \\
serpente. Outros: \\
manual para o \\
professor, Série \\
Didática do I. Butantã \\
e Livros sobre lagartos \\
e serpentes.
\end{tabular} & \begin{tabular}{|l|} 
O kit é apresentado \\
em uma caixa \\
plástica grande com \\
etiquetas de \\
identificação na \\
tampa externa e nas \\
laterais com uma \\
lista de seu conteúdo \\
no interior. Existem \\
animais em via seca \\
e úmida abrigados \\
em caixas menores e \\
frascos de vidro, \\
livros, manual para o \\
professor e modelos. \\
\end{tabular} & $\begin{array}{l}\text { Equipe de } \\
\text { educação } \\
\text { ambiental do } \\
\text { zoológico. }\end{array}$ & $\begin{array}{l}1 \mathrm{a}, 2 \mathrm{a}, 2 \mathrm{~d}, 2 \mathrm{e}, 3 \mathrm{a} \\
4 \mathrm{a}, 4 \mathrm{~b} .\end{array}$ \\
\hline
\end{tabular}




\begin{tabular}{|c|c|c|c|c|c|c|c|}
\hline $\begin{array}{c}\text { NOME DO } \\
\text { KIT }\end{array}$ & CONTEÚDO/CONCEITO & $\begin{array}{l}\text { INDICAÇÃO DE } \\
\text { QUANDO USAR }\end{array}$ & $\begin{array}{c}\text { INDICAÇÃO DE } \\
\text { COMO USAR }\end{array}$ & $\begin{array}{c}\text { ITENS QUE } \\
\text { COMPÕEM O KIT }\end{array}$ & DESCRIÇÃO & AUTORIA & $\begin{array}{c}\text { INDICADORES E } \\
\text { ATRIBUTOS DE } \\
\text { AC }\end{array}$ \\
\hline 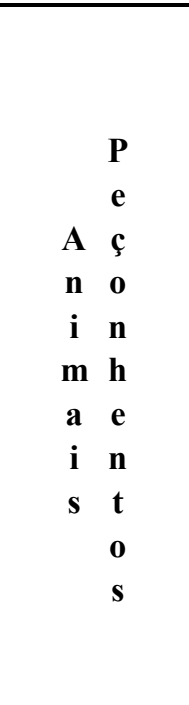 & $\begin{array}{l}\text { Definição de animais peçonhentos, } \\
\text { serpentes do Brasil, características } \\
\text { e história natural, picada, soro, } \\
\text { prevenção de acidentes, medidas } \\
\text { em caso de acidentes, aracnídeos, } \\
\text { características, morfologia externa } \\
\text { e classificação das aranhas e } \\
\text { escorpiões, prevenção de acidentes } \\
\text { com aracnídeos. }\end{array}$ & Não há indicação & Não há indicação & $\begin{array}{l}\text { Animais em via } \\
\text { úmida: aranha- } \\
\text { armadeira, aranha- } \\
\text { caranguejeira, } \\
\text { escorpião-marrom, } \\
\text { escorpião-amarelo, } \\
\text { cobra-coral e cascavel. } \\
\text { Outros: manual para } \\
\text { o professor. }\end{array}$ & $\begin{array}{l}\text { O kit é apresentado } \\
\text { em uma caixa } \\
\text { plástica grande com } \\
\text { etiqueta de } \\
\text { identificação na } \\
\text { tampa e na lateral. } \\
\text { Na parte interna da } \\
\text { tampa há uma lista } \\
\text { de seu conteúdo. } \\
\text { Dentro da caixa } \\
\text { maior existem seis } \\
\text { frasco de vidro com } \\
\text { os animais } \\
\text { conservados em } \\
\text { álcool e um manual } \\
\text { para o professor. }\end{array}$ & $\begin{array}{l}\text { Não há } \\
\text { indicação }\end{array}$ & $\begin{array}{l}1 \mathrm{a}, 2 \mathrm{a}, 2 \mathrm{c}, 2 \mathrm{~d}, 2 \mathrm{e} \\
4 \mathrm{a}, 4 \mathrm{~b}, 4 \mathrm{c} .\end{array}$ \\
\hline
\end{tabular}




\begin{tabular}{|c|c|c|c|c|c|c|c|}
\hline $\begin{array}{l}\text { NOME DO } \\
\text { KIT }\end{array}$ & CONTEÚDO/CONCEITO & $\begin{array}{l}\text { INDICAÇÃO DE } \\
\text { QUANDO USAR }\end{array}$ & $\begin{array}{l}\text { INDICAÇÃO DE } \\
\text { COMO USAR }\end{array}$ & $\begin{array}{c}\text { ITENS QUE } \\
\text { COMPÕEM O KIT }\end{array}$ & DESCRIÇÃO & AUTORIA & $\begin{array}{c}\text { INDICADORES E } \\
\text { ATRIBUTOS DE } \\
\text { AC }\end{array}$ \\
\hline $\begin{array}{l}\mathbf{P} \\
\mathbf{a} \\
\mathbf{r} \\
\mathbf{a} \\
\mathbf{s} \\
\mathbf{i} \\
\mathbf{t} \\
\mathbf{0} \\
\mathrm{s} \\
\mathrm{e} \\
\\
\mathrm{h} \\
\mathbf{u} \\
\mathbf{m} \\
\mathbf{a} \\
\mathbf{n} \\
\mathbf{a}\end{array}$ & $\begin{array}{l}\text { Características gerais, ciclo de } \\
\text { vida, transmissão e prevenção, } \\
\text { gráficos e tabelas sobre presença } \\
\text { da doença, informações sobre os } \\
\text { parasitas presentes no kit. }\end{array}$ & \begin{tabular}{|l|} 
Sala de \\
aula/estudantes e \\
professores, aulas \\
de Ciências, \\
Biologia e Educação \\
Ambiental. \\
\\
\end{tabular} & $\begin{array}{l}\text { Manual do professor, } \\
\text { nomeia a autoria do } \\
\text { material, explicita os } \\
\text { objetivos da criação do kit, } \\
\text { indica que o kit tem } \\
\text { animais e outros materiais, } \\
\text { solicita a leitura de todo o } \\
\text { manual e de observar a } \\
\text { posição de cada objeto na } \\
\text { caixa, sugere que exista } \\
\text { manipulação dos materiais, } \\
\text { chama a atenção para o } \\
\text { cuidado com os materiais. }\end{array}$ & \begin{tabular}{|l|} 
Animais em via \\
úmida: carrapato, \\
caramujo da \\
esquistossomose, \\
nematódeo de tigre, \\
ancilóstomos, \\
proglotes de Taenia \\
solium, lombriga, \\
nematódeo de primata. \\
Outros: Fita VHS, \\
manual para o \\
professor, cartões com \\
o ciclo de vida dos \\
parasitas, 3 pastas com \\
transparências para \\
retroprojetor com \\
ilustrações e ciclos de \\
vida.
\end{tabular} & \begin{tabular}{|l|} 
Os materiais estão \\
abrigados numa \\
caixa plástica grande \\
com a identificação \\
na tampa e na lateral, \\
no seu interior há \\
uma lista do \\
conteúdo do kit. No \\
interior da caixa \\
existem pastas com \\
diversos tipos de \\
materiais \\
complementares, \\
uma fita VHS e \\
manual para o \\
professor, além dos \\
animais originais.
\end{tabular} & \begin{tabular}{|l} 
Equipe de \\
educação \\
ambiental do \\
zoológico. \\
\\
\end{tabular} & $\begin{array}{l}1 \mathrm{a}, 2 \mathrm{a}, 2 \mathrm{c}, 2 \mathrm{~d}, 2 \mathrm{e} \\
3 \mathrm{a}, 4 \mathrm{a}, 4 \mathrm{~b}, 4 \mathrm{c}\end{array}$ \\
\hline
\end{tabular}




\begin{tabular}{|c|c|c|c|c|c|c|c|}
\hline $\begin{array}{c}\text { NOME DO } \\
\text { KIT }\end{array}$ & CONTEÚDO/CONCEITO & $\begin{array}{l}\text { INDICAÇÃO DE } \\
\text { QUANDO USAR }\end{array}$ & $\begin{array}{l}\text { INDICAÇÃO DE } \\
\text { COMO USAR }\end{array}$ & $\begin{array}{c}\text { ITENS QUE } \\
\text { COMPÕEM O KIT }\end{array}$ & DESCRIÇÃO & AUTORIA & $\begin{array}{c}\text { INDICADORES E } \\
\text { ATRIBUTOS DE } \\
\text { AC }\end{array}$ \\
\hline $\begin{array}{c}\mathbf{I} \\
\mathbf{n} \\
\mathbf{t} \\
\mathbf{e} \\
\mathbf{r} \\
\mathbf{a} \\
\mathbf{c} \\
\tilde{\mathbf{a}} \\
\mathbf{0} \\
\mathbf{a} \\
\mathbf{n} \\
\mathbf{i} \\
\mathbf{m} \\
\mathbf{a} \\
\mathbf{1} \\
\mathbf{p} \\
\mathbf{p} \\
\mathbf{l} \\
\mathbf{a} \\
\mathbf{n} \\
\mathbf{t} \\
\mathbf{a}\end{array}$ & \begin{tabular}{|l|} 
Adaptação e evolução, \\
coevolução, dispersão de sementes \\
por animais, interações \\
coevolutivas entre insetos e \\
plantas, herbivoria, liquens, flor, \\
importância da polinização, tipos \\
de polinização, semente e fruto, \\
dispersão de sementes por animais \\
e outros agentes, tabela de \\
polinização de plantas e seus \\
animais correspondentes.
\end{tabular} & \begin{tabular}{|l|} 
Sala de \\
aula/estudantes e \\
professores, aulas \\
de Ciências, \\
Biologia e Educação \\
Ambiental. \\
\\
\\
\end{tabular} & $\begin{array}{l}\text { Manual do professor, } \\
\text { nomeia a autoria do } \\
\text { material, explicita os } \\
\text { objetivos da criação do kit, } \\
\text { indica que o kit tem } \\
\text { animais e outros materiais, } \\
\text { solicita a leitura de todo o } \\
\text { manual e de observar a } \\
\text { posição de cada objeto na } \\
\text { caixa, sugere que exista } \\
\text { manipulação dos materiais, } \\
\text { chama a atenção para o } \\
\text { cuidado com os materiais. }\end{array}$ & $\begin{array}{l}\text { Exsicatas: } 25 \text { espécies } \\
\text { de plantas secas com } \\
\text { identificação e } \\
\text { descrição. Partes de } \\
\text { animais em via seca: } \\
\text { cabeça de arara, } \\
\text { crânio de tucano, } \\
\text { cabeça de tucano e } \\
\text { cabeça de papagaio. } \\
\text { Sementes: mulungu, } \\
\text { palmito jussara, araçá- } \\
\text { roxo, araticum, } \\
\text { castanha-do- } \\
\text { maranhão, aroeira- } \\
\text { pimenteira, angico, } \\
\text { girassol, palmeira. } \\
\text { Outros: manual para } \\
\text { o professor, lupa } \\
\text { manual e pinça, fotos } \\
\text { de animais e plantas. } \\
\text { Frutos e sementes: } \\
\text { bromélia, coco-da- } \\
\text { baía, copaíba, jerivá, } \\
\text { paineira, palmeira- } \\
\text { rabo-de-peixe, } \\
\text { pinheiro, soboeiro. } \\
\text { Ninho: } 1 \text { ninho de ave } \\
\text { não identificado. }\end{array}$ & $\begin{array}{l}\text { O kit está abrigado } \\
\text { numa caixa plástica } \\
\text { grande com etiquetas } \\
\text { de identificação na } \\
\text { tampa e na lateral e a } \\
\text { lista com o conteúdo } \\
\text { está na parte interna } \\
\text { da tampa. Dentro da } \\
\text { caixa existem pastas } \\
\text { com as exsicatas das } \\
\text { plantas, coleção de } \\
\text { fotos de plantas e } \\
\text { animais, duas caixas } \\
\text { com a coleção de } \\
\text { fruto e sementes e as } \\
\text { partes dos animais, } \\
\text { lupa manual e pinça } \\
\text { e um ninho de ave } \\
\text { não identificado. }\end{array}$ & \begin{tabular}{|l} 
Leandro \\
Aranha, \\
Manoela \\
Brazil, Thiago \\
Nogueira, \\
Wilson \\
Marques e \\
equipe de \\
educação \\
ambiental do \\
Zoológico. \\
\end{tabular} & $\begin{array}{l}1 \mathrm{a}, 2 \mathrm{a}, 2 \mathrm{~b}, 2 \mathrm{~d}, 2 \mathrm{e} \\
3 \mathrm{a}, 4 \mathrm{a}, 4 \mathrm{~b}, 4 \mathrm{c}\end{array}$ \\
\hline
\end{tabular}


(continuacão)

\begin{tabular}{|c|c|c|c|c|c|c|c|}
\hline $\begin{array}{l}\text { NOME DO } \\
\text { KIT }\end{array}$ & CONTEÚDO/CONCEITO & $\begin{array}{l}\text { INDICAÇÃO DE } \\
\text { QUANDO USAR }\end{array}$ & $\begin{array}{l}\text { INDICAÇÃO DE } \\
\text { COMO USAR }\end{array}$ & $\begin{array}{c}\text { ITENS QUE } \\
\text { COMPÕEM O KIT }\end{array}$ & DESCRIÇÃO & AUTORIA & $\begin{array}{c}\text { INDICADORES E } \\
\text { ATRIBUTOS DE } \\
\text { AC }\end{array}$ \\
\hline 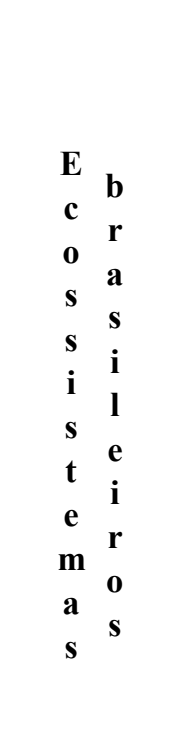 & $\begin{array}{l}\text { Morfologia da flor, diversidade de } \\
\text { plantas, classificação, morfologia e } \\
\text { fisiologia vegetal, como plantar } \\
\text { uma árvore, fitoterapia, plantas } \\
\text { medicinais, conceito de } \\
\text { ecossistemas brasileiros } \\
\text { (características gerais), } \\
\text { manguezais, floresta amazônica, } \\
\text { mata atlântica, cerrado, mata ciliar, } \\
\text { pantanal, caatinga. }\end{array}$ & \begin{tabular}{|l} 
Sala de \\
aula/estudantes e \\
professores, aulas \\
de Ciências, \\
Biologia e Educação \\
Ambiental.
\end{tabular} & \begin{tabular}{|l|} 
Manual do professor, \\
nomeia a autoria do \\
material, explicita os \\
objetivos da criação do kit, \\
indica que o kit tem \\
animais e outros materiais, \\
solicita a leitura de todo o \\
manual e de observar a \\
posição de cada objeto na \\
caixa, sugere que exista \\
manipulação dos materiais, \\
chama a atenção para o \\
cuidado com os materiais. \\
\end{tabular} & $\begin{array}{l}\text { Plantas em via } \\
\text { úmida: cacto, planta } \\
\text { aquática e galho de } \\
\text { bromélia. Exsicatas: } \\
17 \text { pranchas com } \\
\text { exsicatas de plantas de } \\
\text { diversas espécies. } \\
\text { Outros: manual para } \\
\text { o professor, prancha } \\
\text { com morfologia de } \\
\text { uma flor, livro, folheto } \\
\text { da prefeitura de } \\
\text { Sorocaba e apostila } \\
\text { sobre plantas } \\
\text { medicinais. }\end{array}$ & $\begin{array}{l}\text { O kit é apresentado } \\
\text { em uma caixa } \\
\text { plástica grande com } \\
\text { etiquetas de } \\
\text { identificação na } \\
\text { tampa e na lateral e } \\
\text { lista de conteúdo na } \\
\text { parte interna da } \\
\text { tampa. Dentro da } \\
\text { caixa existem três } \\
\text { frascos de vidro } \\
\text { contendo plantas em } \\
\text { álcool e duas pastas } \\
\text { com exsicatas de } \\
\text { plantas e com } \\
\text { material } \\
\text { bibliográfico. }\end{array}$ & $\begin{array}{l}\text { Equipe de } \\
\text { educação } \\
\text { ambiental do } \\
\text { zoológico. }\end{array}$ & $\begin{array}{l}1 \mathrm{a}, 2 \mathrm{~d}, 2 \mathrm{e}, 3 \mathrm{a} 4 \mathrm{a} \\
4 \mathrm{~b}, 4 \mathrm{c}\end{array}$ \\
\hline
\end{tabular}




\begin{tabular}{|c|c|c|c|c|c|c|c|}
\hline $\begin{array}{l}\text { NOME DO } \\
\text { KIT }\end{array}$ & CONTEÚDO/CONCEITO & $\begin{array}{l}\text { INDICAÇÃO DE } \\
\text { QUANDO USAR }\end{array}$ & $\begin{array}{l}\text { INDICAÇÃO DE } \\
\text { COMO USAR }\end{array}$ & $\begin{array}{c}\text { ITENS QUE } \\
\text { COMPÕEM O KIT }\end{array}$ & DESCRIÇÃO & AUTORIA & $\begin{array}{c}\text { INDICADORES E } \\
\text { ATRIBUTOS DE } \\
\text { AC }\end{array}$ \\
\hline $\begin{array}{l}\mathbf{L} \\
\mathbf{i} \\
\mathbf{x} \\
\mathbf{0}\end{array}$ & \begin{tabular}{|l|} 
Definição de lixo, quantidade de \\
lixo produzida no Brasil, \\
classificação do lixo, destinação \\
do lixo, animais que vivem no lixo, \\
alternativas para o lixo, coleta \\
seletiva, lixo e qualidade de vida, \\
reciclagem, consumo responsável.
\end{tabular} & \begin{tabular}{|l|} 
Sala de \\
aula/estudantes e \\
professores, aulas \\
de Ciências, \\
Biologia e Educação \\
Ambiental.
\end{tabular} & $\begin{array}{l}\text { Manual do professor com } \\
\text { dicas de como usar o kit. }\end{array}$ & $\begin{array}{l}\text { Materiais diversos: } 1 \\
\text { caixa com plástico } \\
\text { picado, } 1 \text { caixa com } \\
\text { borracha reciclada, } 1 \\
\text { caixa com fibra de } \\
\text { coco e outra com } \\
\text { xaxim, 1 peneira } \\
\text { plástica, frascos de } \\
\text { vidro com areia, } \\
\text { barrilha, óxido de } \\
\text { alumínio, silicato de } \\
\text { alumínio, } 1 \text { barra de } \\
\text { sabão ecológico, } 1 \\
\text { recipiente plástico } \\
\text { com material não } \\
\text { identificado, } 1 \\
\text { envelope com } \\
\text { amostras de papel } \\
\text { reciclado, } 1 \text { jogo, } \\
\text { modelo de telha feita } \\
\text { com tubo de pasta de }\end{array}$ & $\begin{array}{l}\text { O kit está abrigado } \\
\text { em uma caixa } \\
\text { plástica grande com } \\
\text { etiquetas de } \\
\text { identificação e lista } \\
\text { do material que o } \\
\text { compõe. Todos os } \\
\text { materiais estão } \\
\text { abrigados em } \\
\text { pequenas caixas } \\
\text { plásticas no interior } \\
\text { da maior. }\end{array}$ & \begin{tabular}{|l|} 
Equipe de \\
educação \\
ambiental do \\
zoológico.
\end{tabular} & $\begin{array}{l}\text { 1a, 2a, 2c, 2d, 2e, } \\
3 \mathrm{a}, 4 \mathrm{a}, 4 \mathrm{~b}, 4 \mathrm{c}\end{array}$ \\
\hline
\end{tabular}




\begin{tabular}{|c|c|c|c|c|c|c|c|}
\hline $\begin{array}{c}\text { NOME DO } \\
\text { KIT }\end{array}$ & CONTEÚDO/CONCEITO & $\begin{array}{l}\text { INDICAÇÃO DE } \\
\text { QUANDO USAR }\end{array}$ & $\begin{array}{l}\text { INDICAÇÃO DE } \\
\text { COMO USAR }\end{array}$ & $\begin{array}{c}\text { ITENS QUE } \\
\text { COMPÕEM O KIT }\end{array}$ & DESCRIÇÃO & AUTORIA & $\begin{array}{c}\text { INDICADORES E } \\
\text { ATRIBUTOS DE } \\
\text { AC }\end{array}$ \\
\hline $\begin{array}{l}\mathbf{L} \\
\mathbf{i} \\
\mathbf{x} \\
\mathbf{0} \\
\mathbf{I} \\
\mathbf{I}\end{array}$ & $\begin{array}{l}\text { Definição de lixo, quantidade de } \\
\text { lixo produzida no Brasil, } \\
\text { classificação do lixo, destinação } \\
\text { do lixo, animais que vivem no lixo, } \\
\text { alternativas para o lixo, coleta } \\
\text { seletiva, lixo e qualidade de vida, } \\
\text { reciclagem, consumo responsável. }\end{array}$ & \begin{tabular}{|l|} 
Sala de \\
aula/estudantes e \\
professores, aulas \\
de Ciências, \\
Biologia e Educação \\
Ambiental.
\end{tabular} & $\begin{array}{l}\text { Manual do professor com } \\
\text { dicas de como usar o kit. }\end{array}$ & \begin{tabular}{|l|} 
Modelos de animais: \\
baratas, ratos, cobra, \\
aranha, escorpião. \\
Outros: folhetos com \\
atividades e \\
informações sobre lixo \\
e reciclagem, \\
calendário de papel \\
reciclado, mini tapete \\
com pneu reciclado, \\
sacola com materiais \\
reciclados, jogo, \\
brinquedo de material \\
reciclado, bloco de \\
papel reciclado, chapa \\
de garrafa PET \\
utilizada no \\
Zoológico, modelos \\
de para depósito de \\
lixo reciclável, manual \\
para o professor. \\
\end{tabular} & \begin{tabular}{|l|} 
O kit é apresentado \\
em uma caixa \\
plástica grande com \\
etiquetas de \\
identificação na \\
tampa e nas laterais. \\
Na parte interna da \\
tampa existe a lista \\
do material da caixa. \\
No interior da caixa \\
grande existe uma \\
pasta com material \\
bibliográfico, uma \\
sacola de papel \\
reciclado contendo \\
materiais do \\
cotidiano das \\
pessoas e de \\
escritório, jogos e \\
brinquedos feitos de \\
materiais reciclados, \\
tapetes de carro \\
feitos com pneus \\
reciclados, amostra \\
de chapa feita com \\
garrafa pet utilizadas \\
nos recintos do Zôo.
\end{tabular} & $\begin{array}{l}\text { Equipe de } \\
\text { educação } \\
\text { ambiental do } \\
\text { zoológico. } \\
\\
\\
\\
\end{array}$ & $\begin{array}{l}1 \mathrm{a}, 2 \mathrm{a}, 2 \mathrm{c}, 2 \mathrm{~d}, 2 \mathrm{e} \\
3 \mathrm{a}, 4 \mathrm{a}, 4 \mathrm{~b}, 4 \mathrm{c}\end{array}$ \\
\hline
\end{tabular}


(continuacão)

\begin{tabular}{|c|c|c|c|c|c|c|c|}
\hline $\begin{array}{c}\text { NOME DO } \\
\text { KIT }\end{array}$ & CONTEÚDO/CONCEITO & $\begin{array}{l}\text { INDICAÇÃO DE } \\
\text { QUANDO USAR }\end{array}$ & $\begin{array}{l}\text { INDICAÇÃO DE } \\
\text { COMO USAR }\end{array}$ & $\begin{array}{c}\text { ITENS QUE } \\
\text { COMPÕEM O KIT }\end{array}$ & DESCRIÇÃO & AUTORIA & \begin{tabular}{|c} 
INDICADORES E \\
ATRIBUTOS DE \\
AC \\
\end{tabular} \\
\hline $\begin{array}{l}\text { Í } \\
\mathbf{n} \\
\mathbf{d} \\
\mathbf{i} \\
\mathbf{0} \\
\mathbf{I}\end{array}$ & $\begin{array}{l}\text { Histórico da denominação "Índio", } \\
\text { preconceito, índios isolados, } \\
\text { FUNAI, crenças religiosas dos } \\
\text { povos indígenas, de onde vieram, } \\
\text { língua indígena, aldeias, modo de } \\
\text { vida, alimentação, pintura } \\
\text { corpórea, utensílios, artesanato, } \\
\text { adornos, instrumentos musicais, } \\
\text { brinquedos. }\end{array}$ & $\begin{array}{l}\text { Sala de } \\
\text { aula/estudantes e } \\
\text { professores, aulas } \\
\text { de Ciências, } \\
\text { Biologia e Educação } \\
\text { Ambiental. }\end{array}$ & $\begin{array}{l}\text { Manual do professor com } \\
\text { dicas de como usar o kit. }\end{array}$ & \begin{tabular}{|l|} 
Apetrechos \\
indígenas: pá para \\
virar beiju, escultura \\
de onça, cigarro \\
indígena, cabaça, \\
peixe de madeira, \\
cesto de pesca, cintos, \\
brincos, tornozeleiras, \\
tá, cestos diversos, \\
panela de barro, \\
abanadores, chocalho \\
de tornozelo, cocares, \\
chocalho de casco de \\
tartaruga, esteira, \\
flautas, pedaço de \\
cipó, cano com 3 \\
armas. Outros: \\
manual para o \\
professor, livros sobre \\
cultura e arte indígena, \\
folder e cartões \\
postais com pinturas \\
indígenas.
\end{tabular} & \begin{tabular}{|l} 
O kit fica numa \\
caixa plástica grande \\
com identificação na \\
tampa e na lateral \\
com uma lista do \\
conteúdo na parte \\
interna da tampa. No \\
interior da caixa há \\
uma pasta contendo \\
o manual para o \\
professor, cartões, \\
folders e livros. \\
Existem também 25 \\
objetos de origem \\
indígena \\
identificados e não- \\
identificados.
\end{tabular} & $\begin{array}{l}\text { Equipe de } \\
\text { educação } \\
\text { ambiental do } \\
\text { zoológico. } \\
\end{array}$ & $\begin{array}{l}1 \mathrm{a}, 2 \mathrm{c}, 2 \mathrm{~d}, 2 \mathrm{e}, 3 \mathrm{a} \\
4 \mathrm{a}, 4 \mathrm{~b}, 4 \mathrm{c}\end{array}$ \\
\hline
\end{tabular}




\begin{tabular}{|c|c|c|c|c|c|c|c|}
\hline $\begin{array}{c}\text { NOME DO } \\
\text { KIT }\end{array}$ & CONTEÚDO/CONCEITO & $\begin{array}{l}\text { INDICAÇÃO DE } \\
\text { QUANDO USAR }\end{array}$ & $\begin{array}{l}\text { INDICAÇÃO DE } \\
\text { COMO USAR }\end{array}$ & $\begin{array}{c}\text { ITENS QUE } \\
\text { COMPÕEM O KIT }\end{array}$ & DESCRIÇÃO & AUTORIA & $\begin{array}{c}\text { INDICADORES E } \\
\text { ATRIBUTOS DE } \\
\text { AC }\end{array}$ \\
\hline $\begin{array}{l}\mathbf{I} \\
\mathbf{n} \\
\mathbf{d} \\
\mathbf{i} \\
\mathbf{0} \\
\mathbf{I} \\
\mathbf{I}\end{array}$ & $\begin{array}{l}\text { Histórico da denominação "Índio", } \\
\text { preconceito, índios isolados, } \\
\text { FUNAI, crenças religiosas, } \\
\text { origem, língua indígena, aldeias, } \\
\text { modo de vida, alimentação, pintura } \\
\text { corpórea, utensílios, artesanato, } \\
\text { adornos, instrumentos musicais, } \\
\text { brinquedos. Índios em Sorocaba, } \\
\text { informações sobre a etnia Kuikuro } \\
\text { e seu modo de vida. }\end{array}$ & $\begin{array}{l}\text { Sala de } \\
\text { aula/estudantes e } \\
\text { professores, aulas } \\
\text { de Ciências, } \\
\text { Biologia e Educação } \\
\text { Ambiental. } \\
\end{array}$ & $\begin{array}{l}\text { Manual do professor com } \\
\text { dicas de como usar o kit. }\end{array}$ & $\begin{array}{l}\text { Apetrechos } \\
\text { indígenas: zarabatana, } \\
\text { dardos, boneca de } \\
\text { palha, flauta, peão, } \\
\text { peteca de palha, } \\
\text { brinquedo não } \\
\text { identificado, cuia, } \\
\text { cinto, bracelete de } \\
\text { dente, chocalho, cesta } \\
\text { e rede. Outros: } \\
\text { manual para o } \\
\text { professor, cartões com } \\
\text { pintura corpórea do } \\
\text { Kuikuros, livro para } \\
\text { colorir sobre } \\
\text { brinquedos indígenas } \\
\text { da Amazônia, apostila } \\
\text { "Projeto vivendo e } \\
\text { aprendendo com os } \\
\text { índios". }\end{array}$ & $\begin{array}{l}\text { O kit é apresentado } \\
\text { em uma caixa } \\
\text { plástica grande com } \\
\text { etiquetas de } \\
\text { identificação na } \\
\text { tampa externa e nas } \\
\text { laterais. Na parte } \\
\text { interna da tampa } \\
\text { existe a lista do } \\
\text { material contido na } \\
\text { caixa. A pasta de } \\
\text { elástico contém o } \\
\text { manual do professor, } \\
\text { os cartões e a } \\
\text { apostila. Existem no } \\
\text { kit } 15 \text { objetos de } \\
\text { origem indígena } \\
\text { identificados e não- } \\
\text { identificados. }\end{array}$ & \begin{tabular}{|l|} 
Equipe de \\
educação \\
ambiental do \\
zoológico.
\end{tabular} & $\begin{array}{l}1 \mathrm{a}, 2 \mathrm{c}, 2 \mathrm{~d}, 2 \mathrm{e}, 3 \mathrm{a} \\
4 \mathrm{a}, 4 \mathrm{~b}, 4 \mathrm{c}\end{array}$ \\
\hline
\end{tabular}




\begin{tabular}{|c|c|c|c|c|c|c|c|}
\hline $\begin{array}{l}\text { NOME DO } \\
\text { KIT }\end{array}$ & CONTEÚDO/CONCEITO & $\begin{array}{l}\text { INDICAÇÃO DE } \\
\text { QUANDO USAR }\end{array}$ & $\begin{array}{l}\text { INDICAÇÃO DE } \\
\text { COMO USAR }\end{array}$ & $\begin{array}{c}\text { ITENS QUE } \\
\text { COMPÕEM O KIT }\end{array}$ & DESCRIÇÃO & AUTORIA & $\begin{array}{c}\text { INDICADORES E } \\
\text { ATRIBUTOS DE } \\
\text { AC }\end{array}$ \\
\hline $\begin{array}{l}\mathbf{A} \\
\mathbf{r} \\
\mathbf{t} \\
\mathbf{r} \\
\mathbf{o} \\
\mathbf{p} \\
\mathbf{o} \\
\mathbf{d} \\
\mathbf{e} \\
\mathbf{s}\end{array}$ & $\begin{array}{l}\text { Características gerais do grupo, } \\
\text { nomes populares, modo de vida, } \\
\text { preparação dos animais, coleta, } \\
\text { processo de preparação do } \\
\text { material, informativo sobre } \\
\text { acidentes com artrópodes, } \\
\text { conservação do ambiente para } \\
\text { evitar acidentes com artrópodes. }\end{array}$ & Não há indicação & Não há indicação & $\begin{array}{l}\text { Animais em via seca: } \\
\text { besouro, abelha, } \\
\text { carrapato, mariposa e } \\
\text { casulo (pupa). } \\
\text { Outros: } 2 \text { lupas } \\
\text { manual. Animais } \\
\text { incluídos em resina: } \\
\text { escorpião, } \\
\text { marimbondo, besouro, } \\
\text { lacraia e besouro. }\end{array}$ & \begin{tabular}{|l|} 
Os materiais estão \\
abrigados numa \\
caixa plástica grande \\
com identificação na \\
tampa e na lateral, \\
não há lista de \\
material do kit nem \\
apostila. No interior \\
da caixa grande \\
existem quatro \\
caixas pequenas \\
contendo os \\
materiais do kit.
\end{tabular} & $\begin{array}{l}\text { Equipe de } \\
\text { educação } \\
\text { ambiental do } \\
\text { zoológico. }\end{array}$ & $\begin{array}{l}1 \mathrm{a}, 2 \mathrm{a}, 2 \mathrm{~d}, 2 \mathrm{e}, 3 \mathrm{a} \\
4 \mathrm{a}, 4 \mathrm{~b}, 4 \mathrm{c}\end{array}$ \\
\hline
\end{tabular}




\begin{tabular}{|c|c|c|c|c|c|c|c|}
\hline $\begin{array}{l}\text { NOME DO } \\
\text { KIT }\end{array}$ & CONTEÚDO/CONCEITO & $\begin{array}{l}\text { INDICAÇÃO DE } \\
\text { QUANDO USAR }\end{array}$ & $\begin{array}{l}\text { INDICAÇÃO DE } \\
\text { COMO USAR }\end{array}$ & $\begin{array}{c}\text { ITENS QUE } \\
\text { COMPÕEM O KIT }\end{array}$ & DESCRIÇÃO & AUTORIA & $\begin{array}{c}\text { INDICADORES E } \\
\text { ATRIBUTOS DE } \\
\text { AC }\end{array}$ \\
\hline $\begin{array}{l}\mathbf{A} \\
\mathbf{v} \\
\mathbf{e} \\
\mathbf{s} \\
\mathbf{I}\end{array}$ & $\begin{array}{l}\text { Características gerais das aves, } \\
\text { morfologia externa, alimentação, } \\
\text { locomoção, educação ambiental, } \\
\text { ecologia. }\end{array}$ & Não há indicação & Não há indicação & $\begin{array}{l}\text { Partes de animais em } \\
\text { via seca: pata de } \\
\text { coruja, crânio de } \\
\text { biguá, crânio de } \\
\text { arapapa, crânio de } \\
\text { arara, crânio de irerê, } \\
2 \text { patas de ave não } \\
\text { identificadas, pata de } \\
\text { seriema, bico de } \\
\text { tucano, asa de garça, } \\
\text { crânio de jaburu e } \\
\text { osso da perna de ema. } \\
\text { Penas e ovos: pena de } \\
\text { gavião e ovo de } \\
\text { avestruz. Regurgito } \\
\text { de coruja suindara: } \\
\text { restos de aves e } \\
\text { mamíferos, besouro. } \\
\text { Outros: livro de aves } \\
\text { para colorir, livro } \\
\text { sobre aves da } \\
\text { Amazônia. }\end{array}$ & $\begin{array}{l}\text { O kit fica abrigado } \\
\text { numa caixa grande } \\
\text { de plástico com } \\
\text { identificação na } \\
\text { tampa e nas laterais. } \\
\text { Dentro da caixa } \\
\text { maior estão } 3 \text { caixas } \\
\text { menores } \\
\text { identificadas como } \\
\text { Caixa A, B e C com } \\
\text { os materiais } \\
\text { relacionados. Soltos } \\
\text { na caixa estão os } \\
\text { materiais do kit. } \\
\text { Existem dois } \\
\text { materiais no kit que } \\
\text { estão sem } \\
\text { identificação. } \\
\end{array}$ & \begin{tabular}{|l} 
Equipe de \\
educação \\
ambiental do \\
zoológico.
\end{tabular} & $\begin{array}{l}1 \mathrm{a}, 2 \mathrm{e}, 3 \mathrm{a}, 4 \mathrm{a}, 4 \mathrm{~b} \\
4 \mathrm{c}\end{array}$ \\
\hline
\end{tabular}




\begin{tabular}{|c|c|c|c|c|c|c|c|}
\hline $\begin{array}{l}\text { NOME DO } \\
\text { KIT }\end{array}$ & CONTEÚDO/CONCEITO & $\begin{array}{l}\text { INDICAÇÃO DE } \\
\text { QUANDO USAR }\end{array}$ & $\begin{array}{l}\text { INDICAÇÃO DE } \\
\text { COMO USAR }\end{array}$ & $\begin{array}{c}\text { ITENS QUE } \\
\text { COMPÕEM O KIT }\end{array}$ & DESCRIÇÃO & AUTORIA & \begin{tabular}{|c} 
INDICADORES E \\
ATRIBUTOS DE \\
AC
\end{tabular} \\
\hline $\begin{array}{l}\mathbf{A} \\
\mathbf{v} \\
\mathbf{e} \\
\mathbf{s} \\
\mathbf{I} \\
\mathbf{I}\end{array}$ & $\begin{array}{l}\text { Características gerais das aves, } \\
\text { morfologia externa, alimentação, } \\
\text { locomoção, educação ambiental, } \\
\text { ecologia e observação de aves. }\end{array}$ & Não há indicação & Não há indicação & $\begin{array}{l}\text { Partes de animais em } \\
\text { via seca: bico de } \\
\text { arara, bico de gavião, } \\
\text { pata de garça, pata de } \\
\text { gavião. Animal em } \\
\text { via seca: pomba. } \\
\text { Ninhos: ninho de tico- } \\
\text { tico, ninho de rolinha. } \\
\text { Ovo: ema. }\end{array}$ & \begin{tabular}{|l|} 
O kit fica numa \\
caixa grande plástica \\
com outras 4 \\
menores no seu \\
interior. Um saco \\
plástico com ninhos, \\
binóculo e livros, \\
sem manual para o \\
professor. Os livros \\
contém informações \\
gerais sobre aves, \\
modo \\
de vida, alimentação, \\
reprodução, habitat. \\
Soltas na caixa, duas \\
patas de ema \\
O ovo de ema da \\
caixa não está \\
indicado \\
na lista da tampa.
\end{tabular} & \begin{tabular}{|l} 
Equipe de \\
educação \\
ambiental do \\
zoológico. \\
\\
\\
\\
\end{tabular} & $\begin{array}{l}1 \mathrm{a}, 2 \mathrm{e}, 3 \mathrm{a}, 4 \mathrm{a}, 4 \mathrm{~b} \\
4 \mathrm{c} .\end{array}$ \\
\hline
\end{tabular}




\begin{tabular}{|c|c|c|c|c|c|c|c|}
\hline $\begin{array}{c}\text { NOME DO } \\
\text { KIT }\end{array}$ & CONTEÚDO/CONCEITO & $\begin{array}{l}\text { INDICAÇÃO DE } \\
\text { QUANDO USAR }\end{array}$ & $\begin{array}{l}\text { INDICAÇÃO DE } \\
\text { COMO USAR }\end{array}$ & $\begin{array}{c}\text { ITENS QUE } \\
\text { COMPÕEM O KIT }\end{array}$ & DESCRIÇÃO & AUTORIA & $\begin{array}{c}\text { INDICADORES E } \\
\text { ATRIBUTOS DE } \\
\text { AC }\end{array}$ \\
\hline $\begin{array}{c}\text { M } \\
\mathbf{o} \\
\mathbf{c} \\
\mathbf{h} \\
\mathbf{i} \\
\mathbf{l} \\
\mathbf{a} \\
\mathbf{d} \\
\mathbf{e} \\
\mathbf{c} \\
\mathbf{u} \\
\mathbf{r} \\
\mathbf{i} \\
\mathbf{0} \\
\mathbf{S} \\
\mathbf{i} \\
\mathbf{d} \\
\mathbf{a} \\
\mathbf{d} \\
\mathbf{e} \\
\mathbf{s}\end{array}$ & $\begin{array}{l}\text { Tráfico de aves, caça ilegal de } \\
\text { animais, anilhamento, morfologia } \\
\text { externa, destruição de ambientes, } \\
\text { consumo responsável, } \\
\text { comportamento animal, } \\
\text { alimentação, locomoção, cobertura } \\
\text { do corpo, uso racional de recursos } \\
\text { naturais, conservação. }\end{array}$ & Não há indicação & Não há indicação & $\begin{array}{l}\text { pote com fezes de } \\
\text { anta, anilha, crânio } \\
\text { original de arara-azul, } \\
\text { pata taxidermizada de } \\
\text { ave, microchip, pele } \\
\text { de tamanduá, cano de } \\
\text { tráfico de aves, pele } \\
\text { de serpente, molde de } \\
\text { pata de felino. }\end{array}$ & $\begin{array}{l}\text { O material educativo } \\
\text { é uma mochila de } \\
\text { lona contendo uma } \\
\text { pasta com elástico } \\
\text { com um pedaço de } \\
\text { pele de tamanduá- } \\
\text { bandeira, um cano de } \\
\text { PVC denominado de } \\
\text { "Cano de transporte" } \\
\text { para tráfico de aves, } \\
\text { um pote plástico } \\
\text { com um crânio } \\
\text { original de arara- } \\
\text { azul, um frasco } \\
\text { plástico com um } \\
\text { anilha, um frasco de } \\
\text { vidro com um } \\
\text { microchip, uma pata } \\
\text { taxidermizada de } \\
\text { aves, pele de } \\
\text { serpente, guizo de } \\
\text { cascavel. Não há } \\
\text { apostila. }\end{array}$ & \begin{tabular}{|l} 
Equipe de \\
educação \\
ambiental do \\
zoológico. \\
\\
\\
\end{tabular} & $\begin{array}{l}\text { 1a, } 1 \mathrm{c}, 2 \mathrm{a}, 2 \mathrm{c}, 2 \mathrm{~d} \\
2 \mathrm{e}, 3 \mathrm{a}, 4 \mathrm{a}, 4 \mathrm{~b}, 4 \mathrm{c}\end{array}$ \\
\hline & & & & & & \begin{tabular}{|l|} 
Total indicadores \\
Total atributos
\end{tabular} & $\begin{array}{l}1-27 ; 2-27 ; 3-25 ; 4- \\
27 . \\
1 \mathrm{a}-27 ; 1 \mathrm{~b}-0 ; 1 \mathrm{c}-1 ; 1 \mathrm{~d} \\
-0 ; 1 \mathrm{e}-0 ; 2 \mathrm{a}-11 ; 2 \mathrm{~b}- \\
3 ; 2 \mathrm{c}-8 ; 2 \mathrm{~d}-23 ; 2 \mathrm{e}- \\
27 ; 3 \mathrm{a}-25 ; 3 \mathrm{~b}-0 ; 3 \mathrm{c}- \\
0 ; 4 \mathrm{a}-27 ; 4 \mathrm{~b}-27 ; 4 \mathrm{c}- \\
27 .\end{array}$ \\
\hline
\end{tabular}


APÊNDICE F - Transcrição das entrevistas com a equipe responsável pela concepção, produção e gestão dos materiais educativos do Zôo de Sorocaba.

\section{Entrevista semiestruturada com a responsável pelo empréstimo dos materiais educativos do Parque Zoológico Municipal "Quinzinho de Barros", Sorocaba, SP \\ ENTREVISTA 1}

Nome da Instituição: Parque Zoológico "Quinzinho de Barros", Sorocaba, SP

Nome da Entrevistada: Roberta Araújo Ibanez

Ocupação: Responsável pelo empréstimo dos materiais do Zoo de Sorocaba

Formação: Ensino Médio

Vínculo institucional: Técnica Administrativa

email: robertaaraujoibanez@gmail.com_Telefone: (15) 9-960819076

Data: 28 de Outubro de $2014 \quad$ Início: $14: 15 \mathrm{~h} \quad$ Término: $14: 50 \mathrm{~h}$

Pesquisador $=\mathrm{P}$

Entrevistado $=\mathrm{E}$

(P) Que materiais são emprestados para os professores?

(E) Emprestamos os kits ecológicos, DVDs, jogos, brinquedos e animais empalhados.

(P) Você tem registro disso, agenda, reserva?

(E) Sim, nós fazemos agendamento dos animais e dos kits. O restante não precisa fazer o agendamento e fica 1 semana. Retira e fica 1 semana.

(P) Se o material estiver disponível ele vem e pega. Ele precisa de algum documento?

(E) Preenche um termo de responsabilidade com os dados dele, RG, CPF, endereço, onde vai utilizar o material. Se precisar pode ficar mais tempo com o material se não tiver outra agenda para ele.

(P) Quem pode pegar este material? Só professor?

(E) Não, aluno também pode. Os animais só saem para Sorocaba, não para fora da cidade. Os animais só podem ser emprestados para professores. Antes empresas, igreja etc podiam pegar mas agora só professores. Os outros materiais podem ser para o público em geral. 
(P) Alunos que querem fazer trabalho podem levar os materiais também?

(E) Também podem pegar tudo, se for aqui de Sorocaba pode levar os animais também.

(P) Ele precisa trazer o que para provar que é de Sorocaba?

(E) Só vai preencher os dados. Este documento é necessário por causa da polícia ambiental, pois os animais só podem circular dentro de Sorocaba.

(P) Em Sorocaba ele precisa circular com este documento?

(E) Na verdade, nós estamos fazendo outro documento, por enquanto nós não temos. Estamos pensando em um documento que ficará com a pessoa que levar os animais e com a gente. Para no caso da polícia parar poder explicar porque está com os animais.

(P) Então ele é emprestado para professor, para alunos. Os kits e os animais taxidermizados.

(E) Os animais só podem circular em Sorocaba e com professores, os outros qualquer pessoa pode pegar.

(P) Você sabe para que servem esses materiais, quais são os objetivos desses materiais?

(E) Os professores usam para dar aulas em classe, animais e vídeos. Também usam para exposição, feira de ciências, para montar uma cena com os animais. Mas é mais voltado para aula mesmo.

(P) Vocês não restringem para quem quiser para exposição ou outra coisa que não seja aula?

(E) Até dois meses atrás qualquer pessoa podia levar, agora existe essa restrição de só professor poder levar.

(P) Mas se o professor quiser levar para fazer uma exposição, não tem problema?

(E) Sim, professor pode.

(P) Você é a responsável por esses materiais?

(E) Sim, eu e a Peônia. Quando eu não estou, a Keila pode emprestar.

(P) Vocês fazem alguma avaliação junto ao professor sobre o uso dos materiais?

(E) Antes nós fazíamos, mas faz tempo que não temos isso.

(P) Você tem ideia de porque não se faz essa avaliação? 
(E) Por que houve uma troca de pessoas. Antes havia, mas faz uns 5 ou 6 anos que não se faz. Os relatórios dos empréstimos são entregues para a Peônia.

(P) Tem algum levantamento de que tipo de materiais saem, quantos saem, quais são os mais emprestados?

(E) Sim, isso eu faço, é mensal. Fica com a Peônia. Depois se faz um relatório anual.

Entrevista com a responsável pela manutenção, utilização e avaliação dos materiais educativos do Parque Zoológico Municipal "Quinzinho de Barros", Sorocaba, SP. ENTREVISTA 2

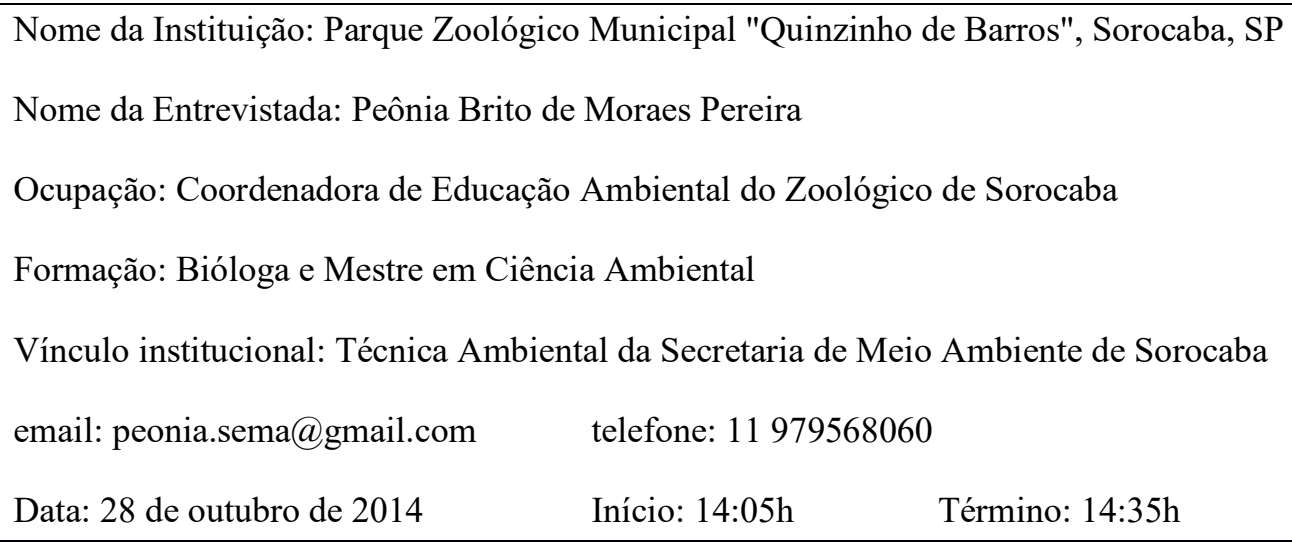

(P) Qual seu vínculo com a instituição?

(E) Funcionária pública, técnica ambiental, desde maio 2013. No Zôo, abril 2014. Antes disso, estava no jardim Botânico de Sorocaba auxiliando na burocracia para a inauguração.

(P) Como você se envolveu com a produção e uso dos materiais educativos do Zôo?

(E) Não tenho envolvimento com a produção dos materiais, eles já existiam, eles são bem antigos e inclusive, necessitam ser reformulados ou pelo menos renovados pois existem peças faltando, já não estão tão boas. O uso não é feito no Zôo, eles saem para empréstimos para os professores da rede pública e particular de Sorocaba. O que se utiliza no Zôo são os animais taxidermizados para exposição, na vitrina, oficinas etc.

(P) E as mochilas? 
(E) As mochilas também tem que dar uma renovada, pois existem itens faltando. Os monitores usam, sempre levam nas visitas monitoradas, mas eu sei que tem itens que estão faltando, por exemplo, o vidro de palmito, quando eles falam do macaco muriqui, da extração ilegal, este item está faltando. Estamos precisando pedir para a polícia ambiental.

(P) Mas as mochilas vocês ainda usam?

(E) Sim, utilizamos.

(P) Na verdade, todos os materiais vocês usam. Alguns para empréstimos e outros aqui no Zôo. Você sabe se esses materiais foram adquiridos ou produzidos aqui?

(E) Eu sei que os jogos foram produzidos por alunos da PUC de Sorocaba como trabalho de conclusão de curso, os kits foram produzidos pela primeira educadora (Neli) ambiental do zoológico, mas não sei como foi o procedimento. Eu sei que foram produzidos no Zôo de Sorocaba, não foram adquiridos.

(P) Você sabe quais eram (são) os objetivos desse material educativo? Se houve alguma mudança nos objetivos com o passar do tempo?

(E) Acho que os objetivos continuam os mesmos, difundir a questão científica para a comunidade escolar de Sorocaba, ajudar para os professores terem um extra para darem as aulas e facilitando também a vida dos professores nas aulas.

(P) E as mochilas?

(E) As mochilas seriam para exemplificar a questão da preservação da natureza com exemplos concretos já que as crianças estão vendo, mas ninguém chegou a me falar sobre as mochilas especificamente. Mas imagino que para exemplificar, em determinado ponto eles estão vendo o animal e conseguem tocar naquele animal, no crânio, no palmito, relacionar o alimento com o animal, deixar mais concreto mesmo a informação. Mais interessante também.

(P) O material foi planejado basicamente para o público escolar. Tem algum outro público que se utiliza deste material?

(E) Eu sei que tinha uma época que nós emprestávamos para outras instituições e até empresas. Mas ultimamente o empréstimo é para escolas e universidades.

(P) As mochilas também? Só público escolar se utiliza das mochilas na monitoria?

(E) Não, quando eventualmente tem algum programa para a comunidade ou em período de férias, nós abrimos um programa de visita monitorada para o público geral, eles se inscrevem e os 
monitores levam as mochilas também. Mas a grande maioria é para o público escolar. Nas quartasfeiras tem a visita da comunidade, outras instituições podem se inscrever para visitas monitoradas. Podem não ser necessariamente escolas, pode ser grupo de igreja, escoteiros...

(P) Na quarta-feira é o único dia que tem visita monitorada para o público não escolar?

(E) Sim, é o único dia que disponibilizamos monitores para o público não escolar...

(P) As visitas para escolares são feitas os outros dias da semana?

(E) Não, temos visitas com monitores para escolas às 3as e 5as. Na segunda feira o Zôo está fechado, às 6as são reuniões internas e capacitação, mas as visitas continuam sem atendimento pelos monitores, é visita livre.

(P) Então 3as e 5as tem visita monitorada para escolas...

(E) Para escolas do município de Sorocaba, da Secretaria de Educação de Sorocaba, do roteiro educador...

(P) E as outras escolas não tem?

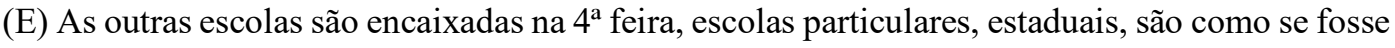
comunidade... na maioria são escolas mesmo...

(P) Então em todas essas oportunidades de visitas monitoradas esse material educativo (mochilas) é utilizado?

(E) Sim é.

(P) Você tem ideia dos pressupostos científicos ou educativos, pedagógicos ou de comunicação que foram utilizados para a produção desse material educativo?

(E) Não

(P) Qual conteúdo científico, conceitos, informações são abordadas nesses materiais, nas mochilas?

(E) A interação, conceito de conservação, interação homem-ambiente, por exemplo, o palmito. Conceitos científicos quando mostra o crânio, o tipo de preparação, que aquele material foi retirado do animal e utilizado para fins científicos, as patas taxidermizadas de um tamanduá. Nesse sentido...

(P) Principalmente questões ambientais, conceitos de ecologia, interação homem-ambiente... 
(E) Sim, isso. E também auxilia a proximidade que a criança vai ter com um material científico no quesito de ser um material de museu, material trabalhado para ser exposto...

(P) E os kits?

(E) Os kits já são diferentes, seguem outra linha. Eles têm uma apostila que o professor vai seguir, vai ter um material teórico básico de acordo com o tema do kit e desenvolver o assunto. Eles são mais exemplificativos de um tema. Ele tem desde interação homem-ambiente até temas de aulas de Ciências, mamíferos, alimentação, reprodução, animais de praias, características, índios, brinquedos e utensílios que eles utilizam. Tem uma diversidade grande, desde temas mais científicos de uma aula de Biologia, como falar de mamíferos, répteis; tem temas mais sociológicos, como por exemplo, falar dos índios ou mais de interação, questão do lixo.

(P) Talvez temas controversos, que tenham mais a ver com o cotidiano da gente?

(E) Sim pode ser.

(P) Vocês têm alguma orientação aos monitores para o uso das mochilas durante a visita monitorada?

(E) Como o programa de visita com as mochilas é antigo e está bastante consolidado, eu não consegui ver todos os materiais documentais arquivados sobre as orientações, eu nunca recebi nenhuma orientação de ninguém. O que acontece é que a orientação é dada pelos estagiários mais velhos para os mais novos. O que é um problema, pois os erros também são passados. É uma coisa que estamos querendo fazer para o próximo ano, rever o discurso deles, talvez rever os materiais das mochilas, ainda vamos conversar sobre isso.

(P) O que você acha das mochilas? Você gosta, acha legal? Você quer que elas continuem?

(E) Elas são bem legais. Eu acho que poderia ter mais materiais, fazer mais mochilas com materiais diferentes. Fazer a visita mais interativa. Desperta a curiosidade das crianças, o pedaço do material taxidermizados ou o animal, eles querem ver de perto, podem pegar.

(P) Você acha interessante e acha que esse material vai se manter?

(E) Se depender de mim o material continua e melhora.

(P) Você acha que esse material proporciona conhecimentos científicos, ele cria uma discussão de conceitos científicos, temas controversos, questões de conservação, tráfico de animais?

(E) Acho sim. Acho que estimula a curiosidade, estimula a atenção das crianças. $\mathrm{O}$ fato de elas terem um objeto para ver, tocar, chegar perto. Na prática é bom eles terem esse material. 
(P) Você acha que a interação é importante no momento da mediação utilizando esse material?

(E) Acho. O cano de transporte de animais traficados as crianças ficam muito interessadas, perguntam como cabe, como eles fazem, são quantos bichos...chama atenção delas...

(P) Isso cria uma discussão polêmica sobre a questão da caça ilegal, do tráfico de animais?

(E) Sim sim.

(P) Você sabe se nas mochilas fala do Zoológico, do que se faz aqui?

(E) Acho que não, nunca ouvi nada desse tipo. A gente sempre tenta falar sobre o zôo, das funções do Zôo, educação, conservação, pesquisa e lazer, que antigamente era a principal função mas hoje é complementar...mas não existe nada concreto na mochila.

(P) O que você espera que o público compreenda com esse material, que o público absorva durante o uso das mochilas?

(E) Acho que é mais ver no concreto, trazer a situação para a realidade, não fica só no discurso. Eu acho que a absorção do conteúdo é a mesma com ou sem a mochila. Eu acho que a mochila facilita, ajuda, chama mais atenção, gera mais interesse mais do que só uma pessoa falando sem nada.

(P) Você acha que esses objetos estimulam e chamam a atenção dos visitantes?

(E) Sim, acho sim.

(P) Vocês avaliaram o uso desse material?

(E) Não sei, talvez tenham sido avaliados antes da minha entrada.

(P) Que efeitos você acha que esse material tem sobre o público que o utiliza?

(E) Efeito positivo e de atenção mesmo. Ajuda a trazer a realidade mais para próximo da pessoa, ajuda na atenção e não fica uma coisa só de história.

(P) Você acha que esses materiais podem estimular ou melhorar a consciência, eles podem incentivar a participação das pessoas na conservação?

(E) Acho que sim, a pessoa vai ver um crânio, por exemplo, você mostra a ameaça e a pessoa vai pensar neles e tentar pensar como ela tá influenciando na ameaça, como poderia ser diferente apesar de algumas vezes serem animais que não estão tão próximos dela. 
(P) Você acha que o material contribui para a compreensão de processos da ciência, no sentido da produção da ciência?

(E) Acho que não porque nós não abordamos esse assunto, porque é mais complexo principalmente com crianças, nós ainda temos que ver como podemos abordar esse assunto.

(P) E os kits de empréstimo para professores?

(E) Acho que os kits já abordam essa questão mais para o professor, porque ele tem muitas peças para exemplificar a aula e os conteúdos e faz o professor ter mais proximidade com o material como foi armazenado e faz o professor passar para os alunos.

(P) Os kits trabalham alguma coisa da instituição, identificam, mostram a função da instituição?

(E) Dos que eu vi, nenhum deles fala.

(P) Vocês têm também coleções de animais taxidermizados, de alguma maneira esse material aborda a importância das coleções?

(E) Isso não é abordado, pelo menos ultimamente.

(P) Você acha que os monitores (usando os materiais) abordam a questão do que o público tem a ver com os temas que são tratados, como isso está relacionado à minha vida? Por exemplo, outras questões como saúde?

(E) Sim, eles falam do palmito, que é feito de maneira pouco higiênica, que eles podem pegar uma doença...

(P) Você acha que isso desperta uma reflexão nas pessoas, elas pensam sobre isso?

(E) Acho que sim.

(P) Você acha que esses materiais educativos podem levar a uma maior autonomia desse público, proporcionarem crítica, fazerem pessoas mais questionadoras?

(E) Acho que sim, a partir das discussões fomentadas pelos materiais. Inclusive pelas discussões a respeito da origem do material. Eles querem saber se a gente mata, como eles foram parar lá, se morreu de doença...

(P) Os materiais são coletados ou são animais daqui do Zoológico mesmo?

(E) São todos que morrem aqui mesmo.

(P) Então não existe a discussão da importância de manter coleções? 
(E) Não existe essa discussão. Nós falamos que eles morreram.

(P) Você acha então que esses materiais estimulam o envolvimento quando você usa as mochilas na visita?

(E) Eu acho que eles ficam mais curiosos e ficam mais dispostos a ouvir. Ficam mais atentos e abertos para ouvir e participar. As perguntas vão surgindo.

(P) Qual a reação deles quando eles veem um pé, um bico, o tubo? O que eles falam? Que tipo de reação eles têm quando vocês mostram? Nas crianças ou nos outros públicos.

(E) Geralmente parte de animais taxidermizados causam repulsa. Alguns tocam, ficam curiosos, outros nem querem chegar perto. O que causa uma reação mais polêmica são as partes de animais. Numa formação com professores, eu mostrei o kit alimentação que fala das adaptações para a alimentação, com a cabeça de um tucano, crânios, tem umas 3 cabeças com o bico, teve professor que não quis nem encontrar, chegar perto, ficaram nervosos...e são adultos e são professores...

(P) Tem alguém que ama, que curte, que adora?

(E) Não. É mais a curiosidade e querer ver, ficar interessado. Mas nunca vi uma reação de amor. Algumas crianças menores acham que é bicho de pelúcia, talvez porque não entendem bem. Ai nós explicamos que eles estão mortos. Acho que com crianças é mais tranquilo.

(P) Você acha que com adultos é mais complicado com peças taxidermizados?

(E) Pelo menos com esse grupo de professores que eu acompanhei foi. Acho que para quem não está acostumado deve dar uma certa estranheza, pegando cadáver.

(P) Você quer falar mais alguma coisa sobre os materiais?

(E) Acho que alguns deles precisam ser revistos com atenção, nomes científicos, materiais velhos, reformulados nos conteúdos. Outra coisa é que não fazemos a avaliação direta. Confere o retorno, mas não com muito profundidade se está com algum dano. As mochilas precisam ser recompostas, porque algumas estão com falta de material e acho que poderiam ter mais materiais.

(P) Quantas mochilas são usadas atualmente?

(E) Inicialmente eram 4 mas hoje usamos 2.

(P) Por que você acha que elas não foram refeitas?

(E) Porque as coisas foram indo, por falta de tempo, outras demandas.

(P) Na avaliação da visita fala alguma coisa específica da mochila? 
(E) Não específica das mochilas.

Entrevista semiestruturada com a responsável pela concepção, elaboração e manutenção dos materiais educativos do Parque Zoológico Municipal "Quinzinho de Barros", Sorocaba, SP

\section{ENTREVISTA 3}

Nome da Instituição: Jardim Botânico "Irmãos Villas Boas" - Sorocaba, SP

Nome da entrevistada: Viviane Aparecida Rachid Garcia

Ocupação: Educadora Ambiental

Formação: Bióloga e Mestre em Educação.

Vínculo institucional: Secretaria da Educação - Prefeitura de Sorocaba.

email: vivi.a.rachid@gmail.com

Telefone: (15) 99719-1818

Data: 17 de outubro de 2014

Início: 11:00h

Término: $12: 31 \mathrm{~h}$

Pesquisador $=(\mathrm{P})$

Entrevistado $=(\mathrm{E})$

(P): Qual era seu vínculo com o Zôo na época?

(E): Eu sou professora de educação infantil, como funcionária estatutária da Secretaria da Educação. Desde a época da faculdade eu fui transferida para o Zoológico, como educadora ambiental e permaneci lá por 17 anos. Eu fui transferida porque na época o Zôo era da Secretaria de Educação. Depois disso o Zôo foi para a Secretaria de Edificação e Urbanismo e somente em 2009, ele foi para a Secretaria do Meio Ambiente.

(P): Você era emprestada da Secretaria da educação para o Zôo? Isto é, para a Secretaria do Meio Ambiente?

(E): Eu sai da Secretaria da Educação e fiquei emprestada para a Secretaria do Meio Ambiente no Zôo.

(P): Você sempre foi Educadora no Zôo?

(E): A partir de 2009 até 2011 eu assumi um cargo de chefia na Secretaria do Meio Ambiente, eu era responsável pela Divisão de Educação Ambiental. Eu exercia metade das minhas funções na Secretaria, na chefia. Então eu pedi para voltar e ficar só como educadora no Zôo e fiquei de 2011 até junho de 2012. Depois eu vim para o Jardim Botânico, em 2013.

(P): No Jardim Botânico você é Educadora? 
(E): Sim, educadora. Estou ligada à Secretaria do Meio Ambiente.

(P): Como você se envolveu com os materiais educativos no Zôo de Sorocaba?

(E): Eu comecei muito preocupada com a visita monitorada. Então eu desenvolvi duas cartilhas, dois guias de visita monitorada para a educação infantil, a última série procurava muito pelo Zôo. A outra foi para o ensino fundamental I. Inclusive pudemos avaliar esse material e observamos que o material feito para a educação infantil foi muito mais aceito pelos alunos maiores porque era mais interativo, mais dinâmico e propunha atividades na sala de aula depois da visita. $\mathrm{Na}$ sequência eu tive oportunidade de produzir um material didático junto com uma estagiária da época, que se tornou o TCC dela, foi um kit sobre o Cerrado. Porque havia um plano de conservação do lobo-guará, que existe há mais de 20 anos. Nós sentíamos falta de um material para falar do lobo-guará mas não descontextualizado, falando do ambiente. Qual é a casa dele? O Cerrado, que é a vegetação de Sorocaba, vegetação de transição entre Cerrado e Mata Atlântica. Então faltava um material que falasse sobre a vegetação da cidade e a biodiversidade animal. Trabalhamos com materiais biológicos referente à flora: como era o tronco? Então a gente tinha um tronco de árvore. Como era a semente? Então tínhamos uma caixa com sementes de plantas do Cerrado. Como eram as folhas? Então tínhamos as exsicatas. Como era o solo? Então fizemos a experiência de granulometria do solo do Cerrado. Como era a fauna? Colocamos alguns objetos biológicos emblemáticos, por exemplo, o lobo-guará. Tínhamos a lobeira, colocamos as fezes, a máscara para o professor reproduzir com os alunos, crânio e pata de coruja-buraqueira, crânio de tamanduá-bandeira, montamos um bingo do Cerrado para mostrar a biodiversidade de flora e fauna. O legal desse bingo é que tinha uma dica para chegar aos animais e vegetais e íamos perguntando para que o público chegasse no nome. Montamos também uma brincadeira sobre a redução do ambiente do Cerrado, quais fatores contribuíam para a destruição desse ambiente, colocamos vídeos sobre o Cerrado com apoio de uma mineradora de MG que tinha um criadouro conservacionista de lobo-guará. Nós procuramos nessa caixa ter um kit bem completo, que desse conta de manusear o objeto biológico da fauna e da flora, ver as relações entre eles, conhecer um pouco da cobertura vegetal do solo, estar mais próximo desse ambiente e dessa vegetação que ocorre no nosso pedaço. A estagiária quis utilizar o kit para o trabalho final então ela se empolgou e foi firme na construção. Esse kit dá conta de todos os aspectos do Cerrado, inclusive a questão do microclima. Nós elaboramos um roteiro para o professor, que era um guia de como utilizar, colocando o máximo de informações de cada objeto que tinha na caixa e descrevendo como utilizar os jogos da caixa. É o kit que mais sai atualmente. Ele dá conta desse assunto de forma completa. Minha contribuição de produção de kit é essa. Os outros kits eu ajudei na manutenção, quando eu cheguei na instituição eles já existiam. Contribui na continuidade deles e discutindo novos usos e novos animais para melhorar. Quais animais vamos colocar, vamos mudar os objetos? Nós temos 4 kits que foram feitos por uma aluna de iniciação científica da PUC 
Sorocaba. Ela fez uma pesquisa do uso dos kits (locomoção, reprodução etc.) mais do ponto de vista da Biologia e alguma coisa de Ecologia. Eu vi a produção desse material acontecendo. Mas eu participei mais da manutenção. Nós tínhamos uma responsabilidade de fazer a manutenção anual do material, pois eles quebram, perdem, ficam obsoletos então tínhamos de ficar sempre fiscalizando.

(P): Fale um pouco sobre as mochilas, por favor.

(E): A produção das mochilas surgiu do fato de eu ser educadora e ter a preocupação de tornar as visitas mediadas mais concretas, mais interativas. Se você vai falar da dentição, de um osso pneumático, de dispersão de sementes, interação, deve oferecer o máximo de recursos que você tiver para ilustrar seu discurso e ser um disparador da mediação. Se for um objeto muito legal vai chamar atenção da criançada para as questões, para elas argumentarem e fica mais fácil para encaminhar a mediação.

(P): As mochilas surgiram depois da produção do kit do Cerrado?

(E): Sim, depois do kit. Além de estimular a mediação nós temos muito material biológico disponível, porque morre bicho o tempo todo, chega bicho morto... e nós não temos taxidermista para preparar tudo. Um crânio nós tínhamos condições de preparar, de descarnar nós mesmos. Então porque não utilizar esse material para educar. Por que hoje em dia quem é que tem possibilidade de segurar, ver, observar como é um crânio de onça, lobo, tatu, tucano ... de ver como é o esqueleto?

(P): Esse material tem um potencial de contribuir com a aprendizagem, um momento único para o público.

(E) Uma outra coisa que eu tinha na cabeça era que as crianças tivessem um momento de vivenciar, de ter uma experiência única, de viver aquele momento único, de poder ter o contato. A Silvia Trivelato na minha dissertação fez uma observação muito interessante. Ela colocou que temos que ter claro o que queremos trabalhar no discurso com objetos biológicos. Ela mencionou que a própria característica do objeto aprisiona o discurso. Então você pode não chegar no objetivo que você quer, no caso a conservação. Você corre o risco de ficar na descrição pura e simples.

(P): Sim, o próprio objeto já constrói um discurso e uma observação por si só. Por isso temos que ver como ele tem sido usado, em que contexto. Você produziram ou compraram esses objetos?

(E): A gente produziu tudo. Inclusive as mochilas foram montadas com os materiais que tínhamos na instituição. Procuramos tudo o que tínhamos disponível, quando não tínhamos condições de ter o objeto, nós ilustrávamos com fotos para esclarecer melhor o conceito. Um recurso visual 
para que a criança não crie um conceito errado. Uma coisa muito legal foi que para fazer as mochilas nós conseguíamos mobilizar a equipe técnica, por exemplo, se íamos falar de dispersão de semente pelos primatas... saia todo mundo pegando coco de primata pelo Zôo, a equipe de tratadores pegava e nós fazíamos o acompanhamento do preparo desse material, a veterinária fornecia os potinhos, todos se envolviam porque todos sabiam o que nós estávamos fazendo. Antes da dissertação nós tínhamos um roteiro de visita monitorada. Depois da minha dissertação, os dados revelaram que eu precisava mudar o discurso do Zoológico para o foco da conservação. Em 2007 eu construí um outro roteiro com as mochilas para que, de fato, os objetos servissem de ponte para o discurso mais efetivo da conservação, o que não estava acontecendo naquele momento. A gente falava que fazia, mas na verdade, não fazia.

(P): Você acha que mudaram os objetivos do uso desses materiais?

(E): Não, pedagogicamente não. A função pedagógica do uso dos objetos para facilitar a mediação continua o mesmo. O que mudou foi a escolha dos objetos em relação ao conteúdo. Eu poderia continuar trabalhando com o bico do tucano ou com o crânio da onça, mas esses materiais não levavam à discussão sobre a manutenção de florestas em áreas urbanas, dispersão de sementes, interação, eu não precisava enfocar nas questões estruturais e morfológicas dos animais e ficar presa nas características externas, porque isso não levava a discussões de conservação.

(P): Então você mudou os objetos para adequar ao seu discurso conservacionista?

(E): Esse exercício foi muito interessante para a equipe. A construção desse novo discurso foi feita coletivamente com os estagiários do setor. O que foi interessante porque os estagiários estavam no cotidiano, e sabiam o que poderia dar certo ou não. $\mathrm{O}$ que mudou então foram os objetos usados para consolidar o discurso. Por exemplo, tinha um crânio de uma onça que tinha levado um tiro por causa da caça predatória, todo mundo via o buraco no crânio. A gente queria falar então porque a onça hoje é morta, por conta da invasão do território para a criação de gado. Como podemos nós aqui em Sorocaba, que não é uma área de criação de gado, contribuir para a conservação da onça? Podemos diminuir o consumo de carne. Nós fizemos um bife de biscuit e começamos a discussão sobre como a carne chega para nós, o boi é criado na floresta onde a onça vivia. Nossa proposta então foi discutir a diversificação da nossa dieta e isso teria uma consequência na diminuição das áreas para criação de gado.

(P): Então você inseriu objetos que estimulassem essa discussão?

(E): Sim, o biscuit e o dente canino da onça para então falar um pouco sobre a onça e olhar o animal no recinto, falar um pouco das características do bicho e chegar no discurso da conservação. Esse discurso tem que ser muito bem estruturado porque se não cansa e dispersa. 
Nossa linha de ação era: faça a sua parte. Como você pode contribuir sem depender do outro. E coletivamente, ai discutimos questões de políticas públicas.

(P): O que tinha nas mochilas?

(E): Bom, então vou falar dos dois momentos, a mochila ecológica-biológica (1) e a mochila conservacionista (2). A mochila (1) tinha bico de tucano, crânio de onça, de bugio, ecdise e chocalho de cascavel. Esta mochila tinha a intenção de discutir aspectos de conservação, mas os objetos levavam a discussão de questões das características do animal, somente. Na mochila (2), crânio de onça com o tiro, bife de biscuit e o canino da onça, fezes de monocarvoeiro (dispersão de semente e manutenção da Mata Atlântica) e um vidro de palmito apreendido, fezes de anta, pedaços da pele do lobo-guará, psitacídeos, cano de PVC, esses materiais e o bicho eram os disparadores e aí nós chegávamos na questão da conservação. Esta mochila já tinha objetos que levavam a discussão de tráfico de aves, diminuição dos ambientes, venda de palmito ilegal, questões de saúde individual. Tudo isso levava a questão: faça a sua parte.

(P): Qual público usava este material? Final de semana, escolar?

(E): Basicamente público escolar de todas as idades. Para o atendimento de final de semana a estratégia era de roteiro de visita autoguiada. Nós temos público universitário grande que passava por vários locais do Zôo e as visitas guiadas mostravam a eles como o setor educativo operava. Todos os públicos de visita monitorada usavam as mochilas. No final da visita havia o manejo de animais vivos e uma discussão de porque os animais estavam invadindo as áreas urbanas, comendo lixo, porque eles estão ficando no telhado da sua casa, o que está acontecendo com a casa deles e discutíamos a questões ambientais da cidade. Porque chega tanta jiboia em Sorocaba, nos sítios, nas estradas. Nós trabalhamos com o lobo-guará somente no mês de outubro que é dia do lobo-guará, não é a rotina na mochila. O público já reconhece o lobo como animal sorocabano porque faz muito tempo que fazemos campanha sobre ele.

(P): Os objetos mudam conforme a necessidade do discurso. Mas sempre tem um tipo de objeto necessário para o discurso que você quer construir?

(E): Sim, sim. Na última mochila, os objetos foram escolhidos para dar conta da demanda ambiental da região. Qual é demanda importante da instituição: falar de tráfico? Vamos escolher um objeto que dê conta disso. Manter as áreas naturais para que pare de chegar bichos mortos, atropelados, queimados? Para conservar as espécies ameaçadas da região? Então escolhemos um animal de Cerrado e Mata Atlântica. Arborizar a cidade? As aves e os gambás estão morrendo, vamos colocar o gambá. Fomos fazendo esses links a partir desses critérios. 
(P): Numa temática geral incluir esses objetos para dar conta de um tema específico dentro dessa temática de conservação?

(E): Quando colocamos a anta, fizemos o link com a Mata Atlântica e fizemos um link com a campanha entre os Zoológicos "Seja amigo da anta", como podíamos participar disso? Nas atividades de rotina, para todo mundo, vai entrar num ponto da visita. Então nós escolhíamos paradas para desenvolver mais porque não dava para falar de todas. Mas acho que tudo isso é ganho do tempo de experiência, também é de parar e olhar para o que está acontecendo, para as questões ambientais da cidade e como a instituição pode ajudar a mudar. Mas isso é depois de um tempo, porque no começo a gente tem outro olhar.

M: Talvez mais conteudista na primeira e com uma preocupação com temáticas mais polêmicos, sociais na segunda?

(E): Sim, mas do ponto de vista da conservação.

(P): Quais os pressupostos científicos, pedagógicos e de comunicação para a produção desse material? No começo era um pressuposto conservacionista, mas não se concretizava, pois, o tipo de objeto aprisionava o discurso?

(E): Não era claro para nós que essa atividade especial tinha que dar conta de todos esses critérios conservacionistas. Para nós, para nosso jeito de ver naquele momento, a gente achou que estava certo. Então de repente você tem uma avaliação a partir de uma pesquisa de Mestrado que deu um resultado: você está falando que faz, mas não faz, precisa mudar isso. Isso dá uma chacoalhada, para ajudar a olhar com outros olhos. Que conservação é essa que eu estou falando?

(P): Quais conceitos e conteúdos vocês abordavam? Mesmo com a perspectiva conservacionista, tem os bichos na mochila, você não deixa de tratar da biologia, dirigir o olhar do visitante que está lá.

(E): Sim, uma interação entre os assuntos.

(P): Como se espera que o público utilize esse material?

(E): Poderia dizer que ele manuseie, que ele conheça as características, que tenha essa experiência direta. Porque todo o material das mochilas era para proporcionar a experiência direta, não tinha nenhum objeto que não podia tocar, mexer ou chegar perto. Inclusive um dos critérios de seleção era que se quebrar, quebrou. Podia tocar em tudo, no vidro de palmito, coco seco etc.

(P): Era uma sensibilização, interação, para despertar uma reflexão? 
(E): Tudo isso era esperado. Mas nós não sabíamos se isso acontecia. A ideia era o visitante, vivenciar, ter o contato direto com os objetos para que ele pudesse explorar das mais diversas maneiras e a mediação conduzia para as reflexões, o questionamento. Mas se ele foi sensibilizado, se ele conseguiu construir conhecimento, isso tudo não conseguimos medir. Mas era um objetivo.

(P): O que se deseja que o público compreenda com esse material? Questão da conservação, interação, experiência, sensibilização?

(E): Sim. Em termos de conteúdo, eles terem clareza de qual o papel deles no meio em vivem em relação à conservação, o que eu posso fazer para melhorar a situação, o que eu posso fazer para conservação esse bicho do meu pedaço? Quando a gente estabelecia o objeto e começava a construir o discurso, a nossa dificuldade era fazer essa ponte: o animal, o objeto e o discurso. De forma que ficasse claro quando fechasse o discurso: faça a sua parte, ele conseguisse ter uma ação concreta a partir de tudo que tinha sido discutido.

(P): E a partir dos objetos que você tinha disponibilizado?

(E): O objeto acaba sendo um disparador, o animal o pano de fundo para chegar na mensagem de conservação. A dificuldade vinha da ideia de que a gente não pode fazer uma transposição errada, a gente não pode simplificar tanto o discurso ao ponto de perder partes e comprometer a compreensão ou dar uma compreensão múltipla, cada um compreende o que quiser porque o discurso permite. A gente teve um problema sério do chimpanzé, quando o parque foi reformado, queriam tirar o chimpanzé para colocar num santuário. O que vocês estão fazendo de conservação para a espécie? A gente está divulgando a espécie. Mas e daí, não é do Brasil? Como eles vão conservar a floresta? Nós fizemos várias pesquisas e descobrimos que o cotan (um minério), que todo mundo usa para segurar a carga do celular, ocorre na região de ocorrência do chimpanzé, para chegar nessas áreas é difícil então você tem trabalho infantil envolvido, destrói a floresta. Como é que aqui você pode ajudar a conservar o chimpanzé de lá? Diminuindo o consumo de eletroeletrônicos, troque seu celular só quando ele quebrar. Tínhamos que ser coerentes para construir o discurso, uma ponte real e não ficar em achismo.

(P): Vocês não avaliaram esse material?

(E): Somente a mochila antiga, depois da pesquisa de mestrado nós reformulamos a mochila mas não tivemos como avaliar.

(P): Que efeito esse material pode ter tido no público?

(E): A mudança mais efetiva foi da equipe técnica. Foram 14 pessoas pensando sobre a mudança de perspectiva da mochila, pensar junto soluções para essas questões. Outro ganho foi da equipe de tratadores e o setor de biologia pensou junto conosco, isso agitou e gerou reflexão. Em relação 
ao público não tenho condições de avaliar se houve um ganho, como eles interagiam com os objetos, se eles aceitavam, se discorriam sobre o assunto em frente ao animal, não entrevistamos nem conversamos com esse público. Nós fizemos alguns ajustes no roteiro no caso da onça, no começo pensamos em colocar a questão da pegada hídrica para produzir um bife, mas fizemos um teste e vimos que havia muita informação, muitas conexões. Então preferimos fazer algo direto, o que você come no almoço e no jantar? Acho que o público teve a oportunidade de conhecer um discurso mais efetivo, agora dizer para você como ele compreendeu o discurso...

(P): Você acha que os conceitos científicos que vocês planejaram foram alcançados com esse material?

(E): Eu diria que eles foram apresentados, mas não podemos esquecer que estamos num universo múltiplo, de cheiro, de sons, de movimento, de expectativas, tudo isso concorre com o objetivo de apresentar nosso roteiro. Nós brincávamos que podíamos ter a melhor mediação mas quem garantia se não estávamos pregando no deserto? Se ele estava mudo ele estava ouvindo ou pensando no bicho que ele queria ver? Só quando ele se manifestava, perguntando, interagindo podíamos saber.

(P): Mas existia esse momento?

(E): Sim, não registramos mas existia os momentos de participação, interação, o que estava chamando mais atenção, ele perguntava, comentava com o colega, trazia conexões da casa e da escola e as verbalizava ali na hora.

(P): Você acha que esse material possibilita o entendimento dos processos científicos, de levantamento de hipóteses, para a pessoa ter noção de como são os processos de produção cientifica?

(E): Eu digo que para a equipe educativa e para os estagiários contribuiu muito. Mas para o público não, porque recebiam o discurso pronto.

(P): Nesse discurso não havia algum fator que fazia ele pensar sobre essas questões de produção da ciência?

(E): Não, no máximo, assim "Esse animal dispersa a semente pelas fezes". Você sabia que tem gente que pesquisou sobre esse assunto? Eles perceberam que a semente germinava a partir do coco. Mas bem sutil.

(P): Em algum momento do uso desse material a instituição estava retratada, discutida? 
(E): Na verdade, no início da visita existia uma apresentação, dos monitores, do Zôo. O que eles estavam fazendo lá? Por que existe Zoológico, por que será que os bichos estão no Zôo? E ai era explicado o objetivo do Zoológico.

(P): Era feito no acolhimento e não no material usado para a mediação?

(E): Não, o objetivo do material era ensinar sobre os animais, seu ambiente e ensinar as pessoas a conservar.

(P): Os materiais produzidos despertavam discussões polêmicas? Me dá um exemplo.

(E): Sim, a questão do palmito. Os adultos questionavam se todos os palmitos ilegais eram prejudiciais à saúde. De conservação houve uma polêmica sobre a onça, dizendo que ela entra nos sítios e mata a criação e pode ser um risco para as pessoas, vocês gostam mais dos bichos ou das pessoas? A gente está defendendo nossa vida, nosso espaço e vocês querem que a gente largue tudo para as onças? Vocês preferem manter a onça viva e a gente não ter espaço para morar, cultivar nossas coisas para poder viver?

(P): Um dos objetivos do material era estabelecer a relação entre o conhecimento científico e o cotidiano das pessoas. Você acha que os materiais educativos podem criar uma autonomia, capacidade crítica nos visitantes que entraram em contato com eles?

$\mathrm{V}$ : Eu acho que sim, depende da forma com que eles receberam tudo isso. Tudo isso foi algo que a gente planejou, executou, mas não avaliou. Você vai poder olhar e analisar os discursos, nós não fizemos isso. Nós vivemos tentando inovar, mudar e melhorar mas esquecemos da avaliação porque não temos pernas para isso, porque temos 500 coisas para fazer.

(P): Você acha que o uso desses materiais contribui para o envolvimento do público com essa temática?

V: Sim, isso é uma percepção somente. Ele pode olhar para o bicho, observar as características externas, observar o comportamento do momento e ele pode ir embora só com a primeira percepção, sem outro conhecimento agregado que tenha relação com o cotidiano dele. Mas isso são escolhas, não quer dizer que não haja um conhecimento da ciência, a biologia, o comportamento animal... isso é conhecimento.

(P): Mas o objetivo da instituição é despertar essa consciência conservacionista, você não acha que o palmito, o PVC com o passarinho não estimula, envolve o público? Melhor do sem esse material? 
V: Sim, claro. Faz parar para pensar. Eu acho, eu penso que sim. Não temos comprovação mas acho que sim. Penso que quando ele olhar um papagaio e ele souber que tem origem ilegal, ele vai lembrar que pode ter vindo num cano de PVC como ele viu no Zôo e que muitos morreram. Pode lembrar do vidro de palmito ilegal que ele viu com o caldo marrom cheio de coliformes fecais e pensar, nossa de onde vem esse palmito que eu estou comendo? Ou quando ele estiver com a mãe ou quando ficar adulto, escolhendo um palmito, ele saber ver a certificação de origem daquele produto. A gente dá condições para isso.

M: Como eram as reações das pessoas, o que elas expressavam quando entravam em contato com esses materiais?

V: Depende dos objetos, tudo era a forma como o monitor colocava. Se ele conseguia chamar a atenção para o material, porque a competição era desleal, um monte de bichos e o cenário maravilhoso. Mas o que mais chamava atenção, o vidro de palmito, quando a gente falava que era coco, dava uma repulsa, nojo. O fato de trabalhar com as fezes. O fato de ver o cano de PVC, de ver sair de lá o papagaio todo destruído, a gente até derretia um pouco de vela vermelha para simular um sanguinho! Ai que dó. Mexia um pouco com a emoção e com a questão do que gosta ou não gosta.

(P): Levava a pessoa a pensar, a repensar, reflexão, na hora de fazer as escolhas. Você acha que despertava essas coisas?

V: Sim, pelo menos é o que a gente esperava e percebia. A minha mãe compra palmito, minha mãe não compra. Em 2011 a gente fez um curso de férias para crianças e a gente levou no supermercado para ensinar a comprar palmito, nós extrapolamos para como fazer uma compra sustentável do ponto de vista da saúde, do ambiente.

(P): Vocês começavam a atividade no Zôo?

V: Três dias do curso foram no Zôo e um dia foi no Extra. O desafio era montar uma festa. As crianças tinham que fazer compra com carrinhos, o Extra se mobilizou e tinha um monitor em cada corredor. A equipe pensou, eu sou Zoológico mas eu posso fazer muito mais do que só ver e mostrar bicho.

(P): Você deseja complementar, alguma coisa que faltou ou que você deseja comentar?

V: Depois que você ler os relatórios se você quiser voltar a me fazer perguntas, porque existem outros pontos que eu talvez não tenha lembrado. Tudo isso que tinha antes e tem agora é uma tentativa de melhoria da mochila, da escolha dos objetos e do discurso, mas que eu vejo isso como um caminho sempre em construção e que era muito forte em mim era trabalhar questões importantes com o público a maior parte do tempo. Pensávamos sempre em colocar mais coisa 
para tentar ver aonde podíamos chegar com esse conhecimento. O primeiro roteiro tinha 7 pontos fixos, depois do teste nós ficamos com 5 pontos.

M: Isto é, 5 pontos onde se utilizava esse material e fazia-se a discussão mais profunda.

$\mathrm{V}$ : Optou-se por reduzir os pontos de parada porque queríamos proporcionar mais discussões sobre aqueles pontos. 
Quadro 3: Análise da interação dos alunos com o material educativo "Mochila de curiosidades" durante visita mediada ao Zôo de Sorocaba

\begin{tabular}{|c|c|c|}
\hline \multicolumn{3}{|c|}{ OBJETO BIOLÓGICO - BICO DO TUCANO } \\
\hline $\begin{array}{l}\text { IDENTIFICAÇÃO DA } \\
\text { SDR }\end{array}$ & DIÁLOGO DA SDR & $\begin{array}{c}\text { INDICADORES E } \\
\text { ATRIBUTOS DE AC }\end{array}$ \\
\hline 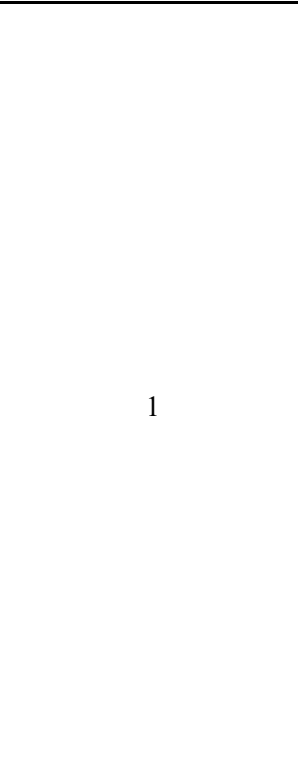 & 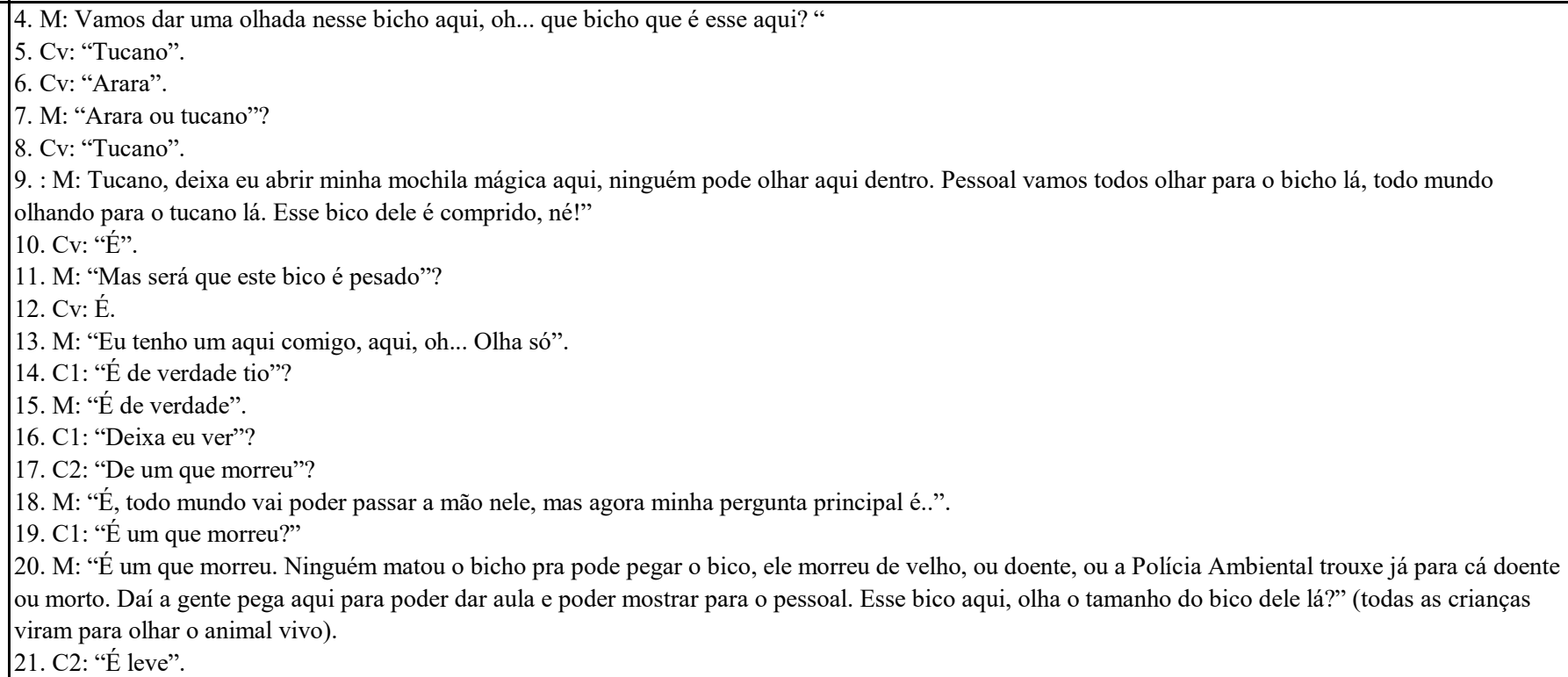 & $1 \mathrm{~A}, 4 \mathrm{~A}, 4 \mathrm{~B}, 4 \mathrm{C}$ \\
\hline
\end{tabular}


Quadro 3: Análise da interação dos alunos com o material educativo "Mochila de curiosidades" durante visita mediada ao Zôo de Sorocaba (continuação) 271

\begin{tabular}{|c|c|c|}
\hline $\begin{array}{c}\text { IDENTIFICAÇÃO DA } \\
\text { SDR }\end{array}$ & DIÁLOGO DA SDR & $\begin{array}{c}\text { INDICADORES E } \\
\text { ATRIBUTOS DE AC }\end{array}$ \\
\hline (1) & $\begin{array}{l}\text { 22. M: Olha o tamanho dele. O tamanho é quase o tamanho do bico dele, não é? E este bico, será que é pesado?". } \\
\text { 23. 22. C1: "Não, é leve". } \\
\text { 24. M: "Porque será?" } \\
\text { 25. C3: "Por quê? Porque ele já é pesado". } \\
\text { 26. P: "Se fosse pesado, como iria ser para ele?". } \\
\text { 27. M: "Se fosse pesado, como ia ser"? } \\
\text { 28. C3: "Ele ia ficar assim, oh..." } \\
\text { 29. C4: "Ele ia ficar caindo tio". } \\
\text { 30. C5: "Tio, porque ele já morreu?" } \\
\text { 31. C2: "Ô, professor se fosse pesado, daí ele não conseguia voar." } \\
\text { 32. M: "Vocês concordam comigo que se ele fosse pesado, ele ia voar assim. (neste momento o monitor imita o tucano voando com a cabeça para baixo). } \\
\text { Não ia voar assim com o bico para baixo assim, oh... Caído, porque o tucano voa assim, oh... Olha o tucano voando.". }\end{array}$ & $1 \mathrm{~A}, 4 \mathrm{~A}, 4 \mathrm{~B}, 4 \mathrm{C}$ \\
\hline
\end{tabular}


Quadro 3: Análise da interação dos alunos com o material educativo "Mochila de curiosidades" durante visita mediada ao Zôo de Sorocaba (continuação) 272

\begin{tabular}{|c|c|c|}
\hline $\begin{array}{l}\text { IDENTIFICAÇÃO DA } \\
\text { SDR } \\
\end{array}$ & DIÁLOGO DA SDR & $\begin{array}{c}\text { INDICADORES E } \\
\text { ATRIBUTOS DE AC } \\
\end{array}$ \\
\hline 3 & $\begin{array}{l}\text { 44. M: Dá uma olhada no bico dele ai oh... Esse bico é leve, não é?". } \\
\text { 45. C1: "É." } \\
\text { 46. M: "Mas será que é forte ou será que é pesado?" } \\
\text { 47. C1: "É forte". } \\
\text { 48. M: "Forte ou fraco?" } \\
\text { 49. Cv: "Fraco } \\
\text { 50. M: "Quem falou que é fraco errou". } \\
\text { 51. C2: "Eu falei". } \\
\text { 52. M: "Esse bico é muito forte. Sabe o que o tucano come? O que vocês acham que o tucano come?" } \\
\text { 53. Cv: "Folha." } \\
\text { 54. M: "Folha, Ah, O que mais? O quê que a arara come?" } \\
\text { 55. C1: "O tio olha para aquele lá." } \\
\text { 56. M: "Tem um monte." (neste momento à maioria das crianças está olhando para outro animal). } \\
\text { 57. C1: "Semente." } \\
\text { 58. M: "Quem acha que o tucano come semente levanta a mão."(somente três crianças levantaram a mão, as demais estavam interessadas no macaco solto } \\
\text { que estava em cima da árvore). } \\
\text { 59. C1: "Semente de Girassol." } \\
\text { 60. M: "Quem já comeu aqueles coquinhos. Cadê, deixa eu ver se tem algum por aqui. “ (o monitor observa o espaço que está para ver se não há uma } \\
\text { palmeira com coquinhos). } \\
\text { 61. Cv: "Eu já comi Tio." } \\
\text { 62. M: "Oh, sabe esses coquinhos que tem... O tucano com esse bicão aqui, ele quebra a semente, e ele come o coquinho. Esse bico é muito forte. }\end{array}$ & $1 \mathrm{~A}, 4 \mathrm{~A}, 4 \mathrm{~B}, 4 \mathrm{C}$ \\
\hline
\end{tabular}


Quadro 3: Análise da interação dos alunos com o material educativo "Mochila de curiosidades" durante visita mediada ao Zôo de Sorocaba (continuação) 273

\begin{tabular}{|c|c|c|}
\hline $\begin{array}{l}\text { IDENTIFICAÇÃO DA } \\
\text { SDR }\end{array}$ & DIÁLOGO DA SDR & $\begin{array}{c}\text { INDICADORES E } \\
\text { ATRIBUTOS DE AC } \\
\end{array}$ \\
\hline 4 & $\begin{array}{l}\text { 63. M: O tucano também faz uma coisa super legal, ele gosta de comer ovo." } \\
\text { 64. Cv: "Ovo?" } \\
\text { 65. M: "O que ele faz? Olha a língua dele, ali oh... Será que dá para ver a língua dele ali, oh?" } \\
\text { 66. Cv: "Eu tô vendo". } \\
\text { 67. C1: "É uma língua preta." } \\
\text { 68. M: "Tem um língua ali, oh. Parece uma barberinha, bem no meio do bico, assim do vão do bico dele." } \\
\text { 69. C1: "É preta, né tio?"” } \\
\text { 70. P: "É comprida." } \\
\text { 71. C2: "Qual é o tamanho?" } \\
\text { 72. M: "É do tamanho do bico. O que ele faz? Ele fura." } \\
\text { 73. C6: "A língua dele fica um pouquinho para fora!" } \\
\text { 74. M: "É, dá para ver ali, oh." } \\
\text { 75. C3. "Eu tô vendo." } \\
\text { 76. C6: "Ah, agora eu tô vendo ali, oh, a linguinha dele ali." } \\
\text { 77. M: "Ele fura e oh, lambe o ovo e manda o ovo para dentro. Come o ovo também." } \\
\text { 78. C1: "A Gema?" } \\
\text { 79. M: "Ele come tudo." } \\
\text { 80. C1: "A casca branca não?" }\end{array}$ & $1 \mathrm{~A}, 4 \mathrm{~A}, 4 \mathrm{~B}, 4 \mathrm{C}$ \\
\hline
\end{tabular}


Quadro 3: Análise da interação dos alunos com o material educativo "Mochila de curiosidades" durante visita mediada ao Zôo de Sorocaba (continuação) 274

\begin{tabular}{|c|c|c|}
\hline $\begin{array}{l}\text { IDENTIFICAÇÃO DA } \\
\text { SDR } \\
\end{array}$ & DIÁLOGO DA SDR & $\begin{array}{c}\text { INDICADORES E } \\
\text { ATRIBUTOS DE AC } \\
\end{array}$ \\
\hline 5 & 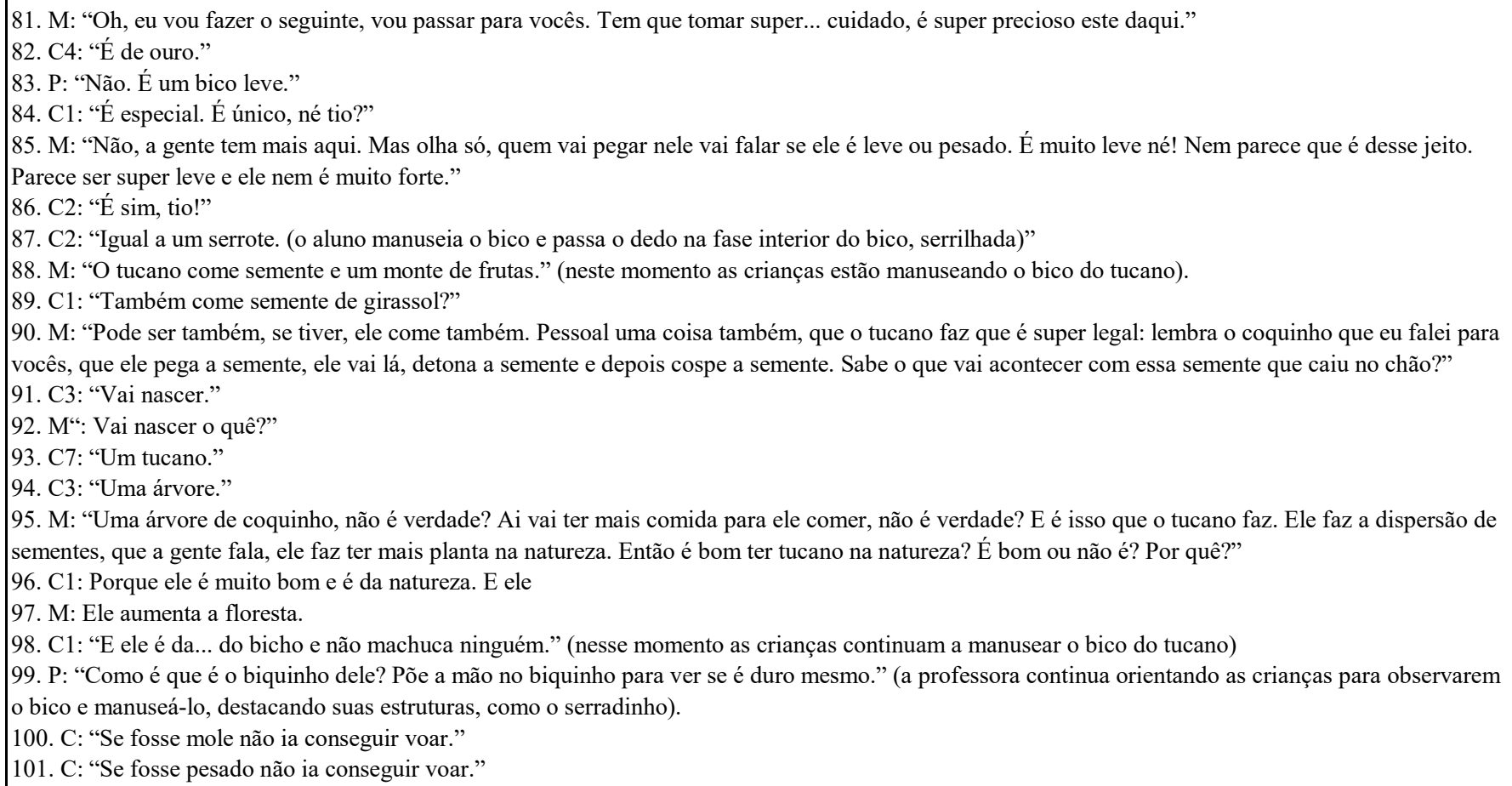 & $1 \mathrm{~A}, 4 \mathrm{~A}, 4 \mathrm{~B}, 4 \mathrm{C}$ \\
\hline
\end{tabular}


Quadro 3: Análise da interação dos alunos com o material educativo "Mochila de curiosidades" durante visita mediada ao Zôo de Sorocaba (continuação) 275

\begin{tabular}{|c|c|c|}
\hline \multicolumn{3}{|c|}{ Objeto biológico trabalhado: muda e guizo de cobra cascavel } \\
\hline $\begin{array}{c}\text { IDENTIFICAÇÃO DA } \\
\text { SDR }\end{array}$ & DIÁLOGO DA SDR & $\begin{array}{c}\text { INDICADORES E } \\
\text { ATRIBUTOS DE AC }\end{array}$ \\
\hline 6 & 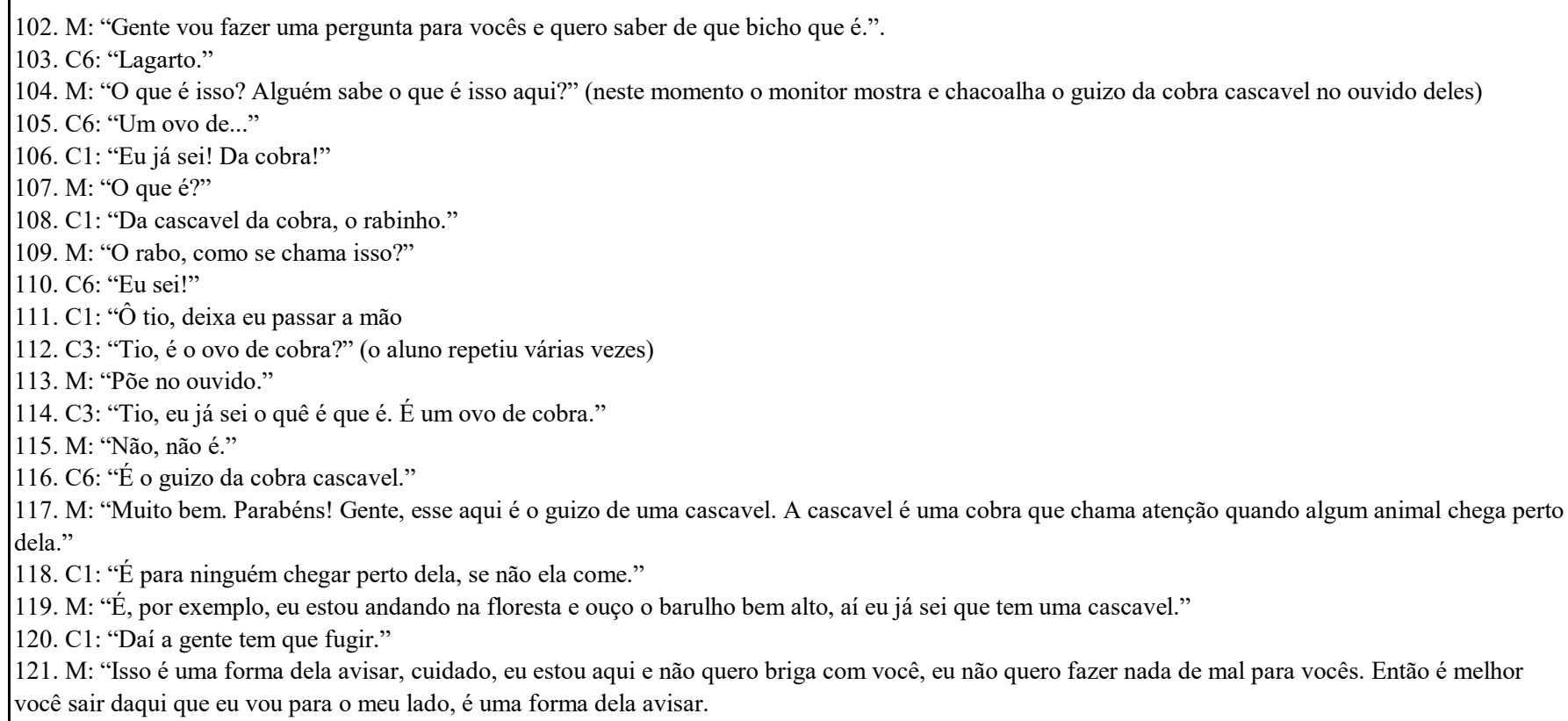 & 1A, 4A, 4B 4C. \\
\hline
\end{tabular}


Quadro 3: Análise da interação dos alunos com o material educativo "Mochila de curiosidades" durante visita mediada ao Zôo de Sorocaba (continuação) 276

\begin{tabular}{|c|c|c|}
\hline $\begin{array}{l}\text { IDENTIFICAÇÃO DA } \\
\text { SDR } \\
\end{array}$ & DIÁLOGO DA SDR & $\begin{array}{c}\text { INDICADORES E } \\
\text { ATRIBUTOS DE AC }\end{array}$ \\
\hline 7 & $\begin{array}{l}\text { 134. M: "Pessoal o que é isso aqui?" (o monitor apresenta a pele da cobra) } \\
\text { 135. C2: "Pele dela." } \\
\text { 136. M: "Pele dela?" } \\
\text { 137. C1: "É tio, pele dela." } \\
\text { 138. C6: "Casca dela." } \\
\text { 139. M: "Ela tira a pele dela?" } \\
\text { 140. C6: "Ela muda de casca." } \\
\text { 141. M: "Porque será que ela muda de casca?" } \\
\text { 142. C2: "Pra ela dizer quando tá velho, ela troca." } \\
\text { 143. M: "Elas estão falando para mim que cobra troca de roupa." } \\
\text { 144. C1: "Troca de casca." } \\
\text { 145. C4: "Tio troca de roupa." } \\
\text { 146. M: "Então vocês falaram para mim que cobra troca de roupa." (nesse momento o monitor pede para todos se sentarem). } \\
\text { 147. M: "Pessoal, vou fazer um pergunta para vocês. Quantos anos vocês têm?"” } \\
\text { 148. C8: "Sete." } \\
\text { 149. M: "Sete. Quando vocês estiverem com vinte e um anos, igual eu tenho, você acha que vai servir nessa roupa que está usando hoje?" } \\
\text { 150. Cv: "Não." } \\
\text { 151. M: "Você vai crescer, não vai? Vai ter que trocar esta roupa. Tem que comprar roupa maior. A cobra compra roupa maior?" } \\
\text { 152. Cv: "Não." } \\
\text { 153. M: "Então, o que é que ela faz?" } \\
\text { 154. C1: "O tio, ela tá com uma... ela vai no meio das pedras, daí quando ela tirar uma, já vai ter outra na pele dela." } \\
\text { 155. M: "Muito bem! Ela falou tudo certinho. A cobra, quando começa apertar esta roupa aqui, o que ela faz? Ela arrasta no meio das pedras, ela troca, e } \\
\text { vai saindo essa pele da cabeça, até a ponta do rabo, certinho do jeito que está aqui, oh (o monitor mostra a muda da cobra que está em suas mãos)." } \\
\text { 156. C1: "O tio, deixa eu catar?" } \\
\text { 157. M: "Embaixo já vai ter uma outra pele para ela poder... com uma pele maior e mais folgada, para ela comer um montão, crescer e trocar de pele de } \\
\text { novo. As cobras nunca param de trocar de pele, elas estão sempre trocando de pele. }\end{array}$ & 1A, 4A, 4B, 4C. \\
\hline
\end{tabular}


Quadro 3: Análise da interação dos alunos com o material educativo "Mochila de curiosidades" durante visita mediada ao Zôo de Sorocaba (continuação) 277

\begin{tabular}{|c|c|c|}
\hline $\begin{array}{l}\text { IDENTIFICAÇÃO DA } \\
\text { SDR }\end{array}$ & DIÁLOGO DA SDR & $\begin{array}{c}\text { INDICADORES E } \\
\text { ATRIBUTOS DE AC } \\
\end{array}$ \\
\hline 8 & $\begin{array}{l}\text { 163. M: Lembra do guizo que eu mostrei para vocês? Tem uma coisa engraçada na cascavel, toda vez que ela troca essa pele aqui, ela ganha um guizo. Se } \\
\text { ela trocar três vezes, essa cobra, de pele ao ano, quantos guizos ela vai ganhar?" } \\
\text { 164. Cv: "três." } \\
\text { 165. M: "Se ela trocar uma vez no ano só?" } \\
\text { 166. Cv: "Um." } \\
\text { 167. M: "Se ela trocar duas vezes no ano?" } \\
\text { 168. Cv: "Duas." } \\
\text { 169. M: "Então é certo falar que a cobra tem cinco guizos. Então ela tem cinco anos." } \\
\text { 170. C1: "É." } \\
\text { 171. Cv: "Não." } \\
\text { 172. M: "Não é. Cada vez que ela troca de pele, ela ganha um guizo. Ela pode trocar de pele duas, três vezes no ano, e esse guizo é muito frágil, pode } \\
\text { quebrar muito fácil. Então não dá para saber a idade da cascavel, então, quanto mais barulho, mais velha ela é, mais guizo ela tem." }\end{array}$ & $1 \mathrm{~A}, 4 \mathrm{~A}, 4 \mathrm{~B}, 4 \mathrm{C}$ \\
\hline 9 & $\begin{array}{l}\text { 193. M: "Oh, eu vou deixar segurar aqui, mas, oh devagar! Vamos passar a mão devagar! Não vamos ter pressa (neste momento o monitor deixa as } \\
\text { crianças manusearem a muda da cobra cascavel)." } \\
\text { 194. C1: "Ai, credo!" } \\
\text { 195. C1: "Dá um beijinho! Deixa eu passar a mão no rabinho dela? } \\
\text { 196. C1: "É mole, né!" } \\
\text { 197. M: "Quando ela troca de pele, ela sai cheia de xixi, toda molhada, daí a gente lava ela e ela fica desse jeito aqui (o monitor mostra a pele). Então essa } \\
\text { daqui já está quebrada, mas quando ela sai, ela sai perfeita. Oh! Esta aqui trocou de pele há pouco tempo." } \\
\text { 198. C2: "Oh, filhotinho! } \\
\text { 199. M: "Esta aqui é filhotinho de cascavel.” } \\
\text { 200. C2: "Tio, a pequenininha também troca de pele?" } \\
\text { 201. M: "Oh, troca. Ela é quem troca mais, porque ela tá crescendo muito, em pouco tempo." }\end{array}$ & $4 \mathrm{~A}, 4 \mathrm{~B}, 4 \mathrm{C}$ \\
\hline
\end{tabular}


Quadro 3: Análise da interação dos alunos com o material educativo "Mochila de curiosidades" durante visita mediada ao Zôo de Sorocaba (continuação) 278

\begin{tabular}{|c|c|c|}
\hline \multicolumn{3}{|c|}{ OBJETO BIOLÓGICO: OVO E PERNA DE EMA } \\
\hline $\begin{array}{l}\text { IDENTIFICAÇÃO DA } \\
\text { SDR }\end{array}$ & DIÁLOGO DA SDR & $\begin{array}{c}\text { INDICADORES E } \\
\text { ATRIBUTOS DE AC } \\
\end{array}$ \\
\hline 10 & $\begin{array}{l}\text { 226. M: "Oh! O que, que é isso aqui pessoal?" (neste instante o monitor apresenta o ovo da ema) } \\
\text { 227. C1: "Um ovo." } \\
\text { 228. C1: "O tio é de verdade" } \\
\text { 229. M: "De quem? De galinha? De pato?" } \\
\text { 230. Cv: "Não." } \\
\text { 231. C3: "Daquele bicho ali, oh." } \\
\text { 232. Cv: "Ema." (as crianças falam bem baixinho) } \\
\text { 233. C1: "De Ema." } \\
\text { 234. M: "De ema, muito bem! A ema mora na região de cerrado. Sabe onde tem cerrado aqui em Sorocaba? Onde?" } \\
\text { 235. C1: "Lá no...?" } \\
\text { 236. M: "No bairro cerrado, no Éden, no Cajuru, é região de cerrado... Aquela parte lá e só cerrado... Cerrado do Brasil... Tem muito cerrado em } \\
\text { Sorocaba. } \\
\text { 237. M: A fêmea bota os ovos. Quem será que cuida dos ovos?" } \\
\text { 238. C3: "O macho." } \\
\text { 239. C1: "A fêmea." } \\
\text { 240. C1: "Quem bota é a fêmea. Quem cuida é o..." } \\
\text { 241. M: "Quem bota é a fêmea ou é o macho?" } \\
\text { 242. Cv: "É a fêmea." } \\
\text { 243. M: "É a fêmea que bota o ovo. E quem cuida do ovo?" } \\
\text { 244. Cv: "O macho." } \\
\text { 245. C3: "Então é o macho aquele." } \\
\text { 246. M: "O macho, muito bem! O macho é quem fica responsável por chocar os ovos e cuidar dos filhotes." }\end{array}$ & $1 \mathrm{~A}, 4 \mathrm{~A}, 4 \mathrm{~B}, 4 \mathrm{C}$ \\
\hline
\end{tabular}


Quadro 3: Análise da interação dos alunos com o material educativo "Mochila de curiosidades" durante visita mediada ao Zôo de Sorocaba (continuação) 279

\begin{tabular}{|c|c|c|}
\hline $\begin{array}{l}\text { IDENTIFICAÇ̃̃O DA } \\
\text { SDR }\end{array}$ & DIÁLOGO DA SDR & $\begin{array}{c}\text { INDICADORES E } \\
\text { ATRIBUTOS DE AC }\end{array}$ \\
\hline 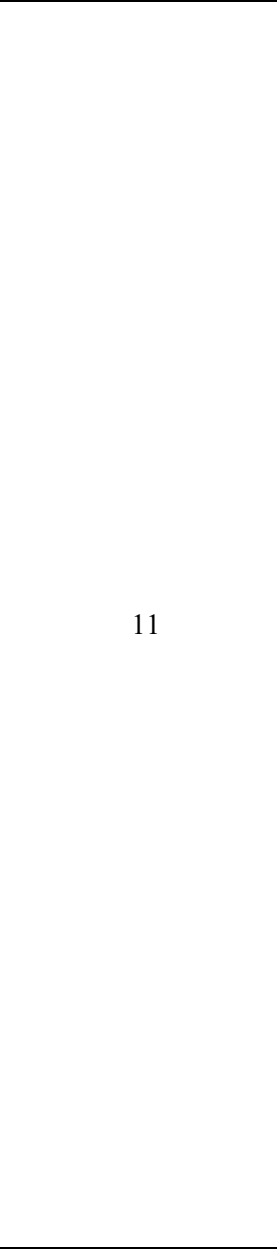 & 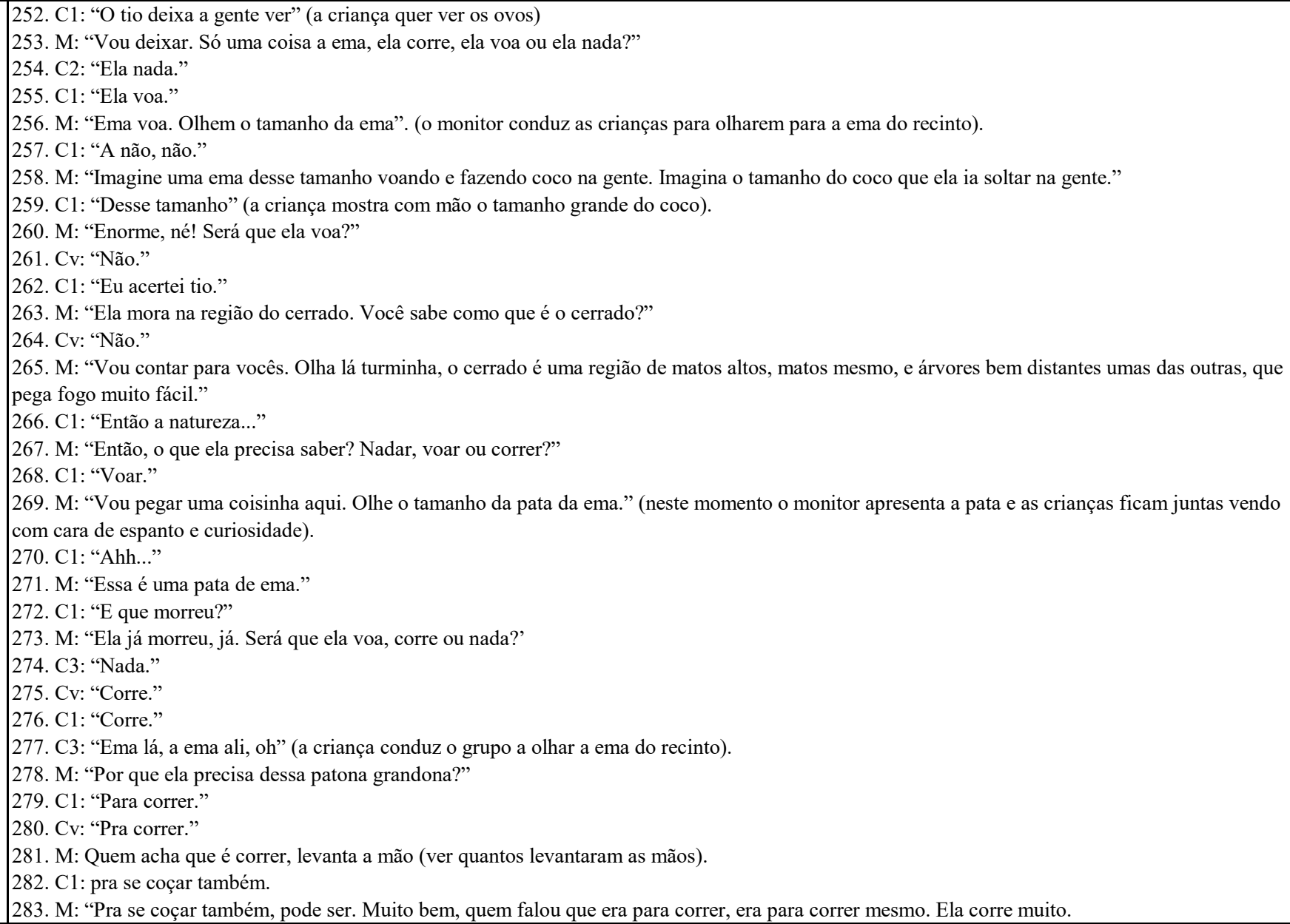 & $1 \mathrm{~A}, 4 \mathrm{~A}, 4 \mathrm{~B}, 4 \mathrm{C}$ \\
\hline
\end{tabular}


Quadro 3: Análise da interação dos alunos com o material educativo "Mochila de curiosidades" durante visita mediada ao Zôo de Sorocaba (continuação) 280

\begin{tabular}{|c|c|c|}
\hline \multicolumn{3}{|c|}{ OBJETO BIOLÓGICO: CRÂNIO DE TAMANDUÁ-BANDEIRA } \\
\hline $\begin{array}{l}\text { IDENTIFICAÇÃO DA } \\
\text { SDR }\end{array}$ & DIÁLOGO DA SDR & $\begin{array}{c}\text { INDICADORES E } \\
\text { ATRIBUTOS DE AC }\end{array}$ \\
\hline 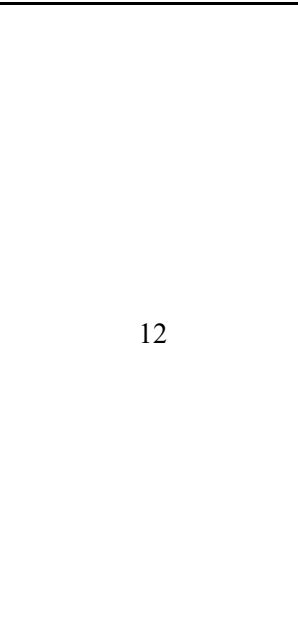 & $\begin{array}{l}\text { 297. M: "Atenção, turminha! Turminha vem cá! Que bicho será que é aquele?" } \\
\text { 298. C1: "Tamanduá." } \\
\text { 299. M: "Tamanduá, o que?" } \\
\text { 300. Cv: "Bandeira." } \\
\text { 301. M: "Tamanduá bandeira, muito bem! Gente vou pegar uma coisinha para vocês darem uma olhadinha. Pessoal, o que é isso?" (neste momento o } \\
\text { monitor apresenta o crânio de tamanduá e até as crianças de outra escola que estão em frente ao recinto do tamanduá se interessam pelo objeto e começam } \\
\text { a participar). } \\
\text { 302. Cv: "Bico." } \\
\text { 303. Cv: "É a cabeça dele." } \\
\text { 304. C3: "É o focinho." } \\
\text { 305. M: "Um bico? É um tucano para ter bico?" } \\
\text { 306. C3: "Não, é o focinho dele." } \\
\text { 307. Cv: "É a boca." } \\
\text { 308. Cv: "A perna." } \\
\text { 309. Cv: "A cocha." } \\
\text { 310. M: "Gente, esse aqui é um crânio de tamanduá bandeira. Esse aqui é a cabeça dele. Vamos dar uma olhada no bicho lá. Olha a língua dele, olha a } \\
\text { língua dele." }\end{array}$ & $1 \mathrm{~A}, 4 \mathrm{~A}, 4 \mathrm{~B}, 4 \mathrm{C}$ \\
\hline 13 & $\begin{array}{l}\text { 415. M: "Oh, eu vou passar... Vocês vão passando para o amiguinho." (neste momento o monitor passa o crânio do tamanduá para manuseio). } \\
\text { 416. Cv: "Eu não quero ver não." (um grupo de crianças continua olhando os animais e o outro vai manusear o crânio do tamanduá) } \\
\text { 417. C2: "Eu quero." } \\
\text { 418. C1: "Que beijinho dorme dorme...da para mim depois..." } \\
\text { 419. C4: "Alá, a linguona dele, tia. } \\
\text { 420. C1: "Dá pra mim depois." } \\
\text { 421. C3: "Alá, a gosmenta dele.". } \\
\text { 422. C2: "É para ele." } \\
\text { 423. C1: "É pra mim, porque aquela hora foi assim." }\end{array}$ & 4A, 4B, 4C. \\
\hline
\end{tabular}


Quadro 3: Análise da interação dos alunos com o material educativo "Mochila de curiosidades" durante visita mediada ao Zôo de Sorocaba (continuação) 281

\begin{tabular}{|c|c|c|}
\hline \multicolumn{3}{|c|}{ OBJETO BIOLÓGICO: CRÂNIO DE ONÇA-PINTADA } \\
\hline $\begin{array}{c}\text { IDENTIFICAÇÃO DA } \\
\text { SDR } \\
\end{array}$ & DIÁLOGO DA SDR & $\begin{array}{c}\text { INDICADORES E } \\
\text { ATRIBUTOS DE AC } \\
\end{array}$ \\
\hline 14 & $\begin{array}{l}\text { 431. P: "O que será que vai sair daí agora?"' (a professora refere-se a mochila de curiosidades) } \\
\text { 432. C1: "A tromba." (as crianças acham que é um objeto relacionado ao elefante que fica em um recinto em frente à onça). } \\
\text { 433. Cv: "A boca". } \\
\text { 434. Cv: "O elefante". } \\
\text { 435. M: "Você acha que iria caber na minha mochilinha a boca do elefante? A boca do elefante é enorme". } \\
\text { 436. C3: "“u já sei a tromba". } \\
\text { 437. C4: "É a pata". } \\
\text { 438. P: "O que será isso hein?"'(nesse momento monitor mostra o crânio da onça) } \\
\text { 439. Cv: "É do Leão". } \\
\text { 440. C2: "Ah, eu sei o que é isso daí, é aquela..." (a criança aponta para sua cabeça) } \\
\text { 441. M: "É um crânio." } \\
\text { 442. C3: "Ele morreu." } \\
\text { 443. M: "Oh, todos os bichos que eu parei para mostrar para vocês são bichos brasileiros. Que bicho será que é esse daqui??" (o monitor aponta para o } \\
\text { crânio da onça) } \\
\text { 444. C1: "Leão, onça." } \\
\text { 445. M: "Leão é brasileiro?" } \\
\text { 446. CI: "Da onça." } \\
\text { 447. M: "Da onça, muito bem! }\end{array}$ & $1 \mathrm{~A}, 4 \mathrm{~A}, 4 \mathrm{~B}, 4 \mathrm{C}$ \\
\hline 15 & $\begin{array}{l}\text { 448. M: O que, que a onça come?" } \\
\text { 449. C2: "Carne." } \\
\text { 450. M: "Carne. Então esses dentes dela aqui servem para que?" } \\
\text { 451. C2: "Para comer a carne." } \\
\text { 452. C1: "Para morder." } \\
\text { 453. M: "E esses dois dentões aqui da frente?" } \\
\text { 454. C3 "Para morder." } \\
\text { 455. M: "Os dentes nossos do fundo serve para o que? Os nossos." } \\
\text { 456. Cv: "Para mastigar." } \\
\text { 457. M: "Para mastigar, muito bem! Esses dentes como é que é? Ele é reto, num é??" } \\
\text { 458. Cv: "É.”. } \\
\text { 459. M: "Esse dente aqui oh, como que ele é? O que, que tem aqui? Cheio de ponta, né? Para que, que serve esse dente aqui??" }\end{array}$ & $1 \mathrm{~A}, 4 \mathrm{~A}, 4 \mathrm{~B}, 4 \mathrm{C}$ \\
\hline
\end{tabular}


Quadro 3: Análise da interação dos alunos com o material educativo "Mochila de curiosidades" durante visita mediada ao Zôo de Sorocaba (continuação) 282

\begin{tabular}{|c|c|c|}
\hline $\begin{array}{c}\text { IDENTIFICAÇÃO DA } \\
\text { SDR } \\
\end{array}$ & DIÁLOGO DA SDR & $\begin{array}{r}\text { INDICADORES E } \\
\text { ATRIBUTOS DE AC } \\
\end{array}$ \\
\hline 16 & $\begin{array}{l}\text { 460. C1: "Tio porque tem esse aqui..." (a criança aponta para a etiqueta de identificação da peça do museu). } \\
\text { 461. M: "Tem marcação". } \\
\text { 462. C1: "Marcação do homem que morreu, né." } \\
\text { 463. M: "Não, marcação para saber que bicho que é..." }\end{array}$ & $1 \mathrm{~A}, 4 \mathrm{~A}, 4 \mathrm{~B}, 4 \mathrm{C}$ \\
\hline 17 & $\begin{array}{l}\text { 464.M: "Para que, que serve esses dentões todo cheio de ponta?" } \\
\text { 465. P: "Pra que será?" } \\
\text { 466. Cv: "Para ele poder pegar as coisas." } \\
\text { 467. M: "Pegar, como assim?"” } \\
\text { 468. C3: "Pega e coloca a pata." } \\
\text { 469. M: "O nosso também dá para pegar." } \\
\text { 470. C3: "Tio, pegar, colocar a pata e puxar.". } \\
\text { 471. M: "Dá para rasgar, segurar assim?" (o monitor mostra com as mãos). } \\
\text { 472. C3: "É." } \\
\text { 473. M: "Muito bem! Esse dentão dele aqui serve pra rasgar... se fosse pra morder pra poder matar o bicho... esse aqui oh, serve pra rasgar..." } \\
\text { 474. C1: "O tio a gente vai ver agora, a gente vai catar." (a criança quer manusear o objeto). } \\
\text { 475. M: "Oh, de todos os gatos que tem no mundo todo, a onça-pintada é o maior do Brasil. Vocês sabem que a onça é um gato? O leão também é um } \\
\text { gato, o tigre também é um gato. Oh, o tigre é o maior gato do mundo." } \\
\text { 476. C1: "Ele é famoso." } \\
\text { 477. M: "É o do Brasil, o maior gato é a onça-pintada." }\end{array}$ & $1 \mathrm{~A}, 4 \mathrm{~A}, 4 \mathrm{~B}, 4 \mathrm{C}$ \\
\hline
\end{tabular}




\begin{tabular}{|c|c|c|}
\hline 18 & $\begin{array}{l}\text { 537. M: "Oh pessoal, quem quiser segurar ela para passar a mão, vai poder (nesse momento as crianças manuseiam o crânio)". } \\
\text { 538. C1: "Tio, o que é isso daqui?" (a criança aponta para uma parte no crânio da onça) } \\
\text { 539. M: "Esse aqui... Esse é um ossinho que ..." } \\
\text { 540. C1: "Que gruda." (a criança compara com o seu crânio e aponta para a sua nuca). } \\
\text { 541. M: "É um ossinho que liga com o osso da sua a coluna. Sabe a coluna ela tem um monte de vértebras, e um monte de osso que encaixa certinho aqui e } \\
\text { aqui fica o cérebro dele." } \\
\text { 542. C1: "Cérebro, oh, vocês tiraram } \\
\text { 543. M: "Tiraram tudo." } \\
\text { 544. C1: "O tio mais o que você fez com o cérebro?" } \\
\text { 545. M: "Olha que maldade! Como essa onça morreu! Ela tomou um tiro aqui e saiu aqui (o monitor mostra o furo de bala no crânio da onça). Tem gente } \\
\text { que mata a onça porque a onça come o gado, aí o pessoal tá invadindo o terreno das onças, tão pegando floresta para colocar gado, aí as onças acabam } \\
\text { comendo os gados das pessoas." } \\
\text { 546. Cv: "Tiro!" (neste momento todas as crianças querem manusear o crânio, as crianças queriam saber mais sobre o tiro do crânio da onça). }\end{array}$ & $1 \mathrm{~A}, 4 \mathrm{~A}, 4 \mathrm{~B}, 4 \mathrm{C}$. \\
\hline
\end{tabular}


Quadro 3: Análise da interação dos alunos com o material educativo "Mochila de curiosidades" durante visita mediada ao Zôo de Sorocaba (conclusão) 283

\begin{tabular}{|c|c|c|}
\hline $\begin{array}{l}\text { IDENTIFICAÇÃO DA } \\
\text { SDR } \\
\end{array}$ & DIÁLOGO DA SDR & $\begin{array}{c}\text { INDICADORES E } \\
\text { ATRIBUTOS DE AC } \\
\end{array}$ \\
\hline \multirow[t]{3}{*}{ 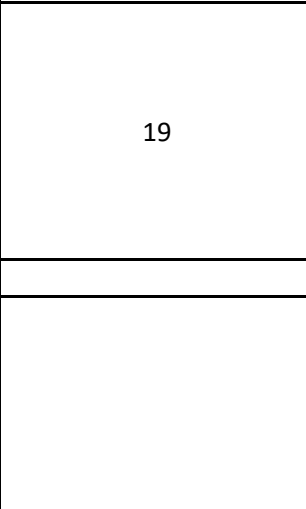 } & $\begin{array}{l}\text { 550. M: "Gente vou fazer uma pergunta? Vocês têm um dente um canino assim? Esse daqui é um dente canino (o monitor aponta para o dente canino no } \\
\text { crânio da onça). Vocês têm uma presa igual ao dele?" } \\
\text { 551. Cv: “Ah, esse daqui??" (as crianças apontam para o seu dente canino) } \\
\text { 552. M: “Qual? Deixa eu ver... Você não tem.” } \\
\text { 553. C3: "Não é o que caiu, o seu é os dois que caiu". } \\
\text { 554. M: “Não, é esse daí mesmo. É igual ao dele. Alguém mais tem alguma pergunta?" }\end{array}$ & $1 \mathrm{~A}, 4 \mathrm{~A}, 4 \mathrm{~B}, 4 \mathrm{C}$ \\
\hline & Total de indicadores & $1-17 ; 2-0 ; 3-0 ; 4-19$ \\
\hline & Total de atributos & $\begin{array}{l}1 \mathrm{~A}-17 ; 1 \mathrm{~B}-0 ; 1 \mathrm{C}-0 ; 1 \mathrm{D}- \\
0 ; 1 \mathrm{E}-0 ; 2 \mathrm{~A}-0 ; 2 \mathrm{~B}-0 ; 2 \mathrm{C} \\
-0 ; 2 \mathrm{D}-0 ; 2 \mathrm{E}-0 ; 3 \mathrm{~A}-0 \\
3 \mathrm{~B}-0 ; 3 \mathrm{C}-0 ; 4 \mathrm{~A}-19 ; 4 \mathrm{~B}- \\
19 ; 4 \mathrm{C}-19 .\end{array}$ \\
\hline
\end{tabular}


ANEXO A - Autorizações de pesquisa no Parque Zoológico Municipal Quinzinho de Barros.
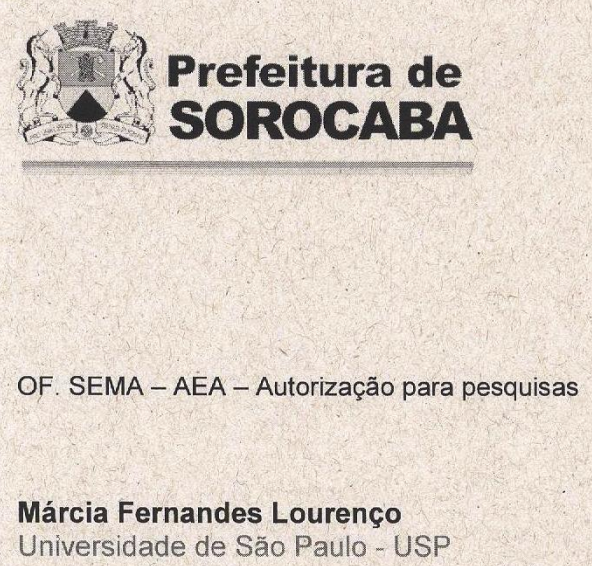

Márcia Fernandes Lourenço

Universidade de São Paulo - USP

OF. SEMA - AEA - Autorização para pesquisas

\section{Secretaria do Meio Ambiente}

Sorocaba, 20 de outubro de 2014

A Secretaria do Meio Ambiente autoriza a Universidade de São Paulo USP, representada pela doutoranda Márcia Fernandes Lourenço, a realizar projeto de pesquisa - "Análise de materiais didáticos produzidos em museus de história natural e de ciência que tratam do conceito de biodiversidade"

As atividades serão realizadas durante os meses de outubro de 2014 até dezembro de 2014.

Atenciosamente,

Aldo José Bittencolurt Lopes Teixeira

Chefe de Seção de Educação Ambiental em Parques 


\section{AUTORIZAÇÃO PRÉVIA PARA PESQUISA CIENTÍFICA REQUERIMENTO}

Eu, Márcia Fernandes Lourenço, RG n 11.724.263-9 solicito autorização da Secretaria do Meio Ambiente para realizar pesquisa científica no Parque Zoológico Municipal Quinzinho de Barros.

Instituição: Universidade de São Paulo

Curso: Doutorado

Pesquisador Principal: Márcia Fernandes Lourenço

Telefone:1198262-3767 e-mail:mfer@usp.br

Título do Trabalho: Análise de materiais didáticos produzidos em museus de história natural e de ciência que tratam do conceito de biodiversidade

Tipo de pesquisa: observação e entrevista com público visitante, entrevista com educadora e com responsável por empréstimo de kits, análise de documentos e análise dos kits de empréstimo para professores. As entrevistas e observações serão gravadas em áudio e em vídeo e serão somente usadas em atividades didáticas e em publicações acadêmicas, preservando sempre a identidade dos sujeitos da pesquisa.

Nome do Orientador: Profa. Dra. Martha Marandino

Telefone: 11 3091-2404 e-mail: marmaran@usp.br

\section{Agendamento:}

Data de início: outubro de 2014

Previsão de término: dezembro de 2014

Contando com a autorização desta instituição, coloco-me à disposição para qualquer esclarecimento.
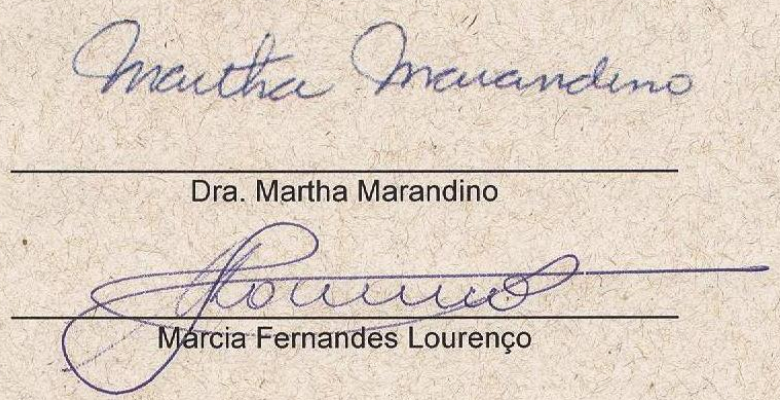

OBS: Informo que a atividade proposta não acarretará nenhum custo para a Prefeitura. 


\section{ANEXO B - Termos de consentimento livre e esclarecido para divulgação das entrevistas} das profissionais do Parque Zoológico Municipal Quinzinho de Barros.

\section{TERMO DE CONSENTIMENTO LIVRE E ESCLARECIDO}

Prezada Peônia Brito de Moraes Pereira

Gostariamos de convidá-la a participar de uma "pesquisa que será realizada na Faculdade de Educação da Universidade de São Paulo.

Sou pós-graduanda da referida universidade e estou cursando o doutorado em Ensino de Ciências.

Desde já quero agradecer a sua disponibilidade em ajudar no desenvolvimento dessa pesquisa. Sua colaboração é importante e necessária, porém sua participação é voluntária.

Para compreender o papel dos materiais educativos existentes em espaços na alfabetização científica da população, farei entrevistas semiestruturadas com gestores ou responsáveis pelos setores de comunicação das instituições que possuam esse material. As atividades serão gravadas, mas as informações serão utilizadas somente para os fins desta pesquisa e serão tratadas com o mais absoluto sigilo e confidencialidade, de modo a preservar a sua identidade.

Você pode recusar-se a participar, ou mesmo desistir a qualquer momento sem que isto acarrete qualquer ônus ou prejuízo à sua pessoa. E sendo um participante voluntário, você não terá nenhum pagamento e/ou despesa referente à sua participação no estudo.

Caso você tenha dúvidas ou necessite de maiores esclarecimentos pode me contatar.

Pesquisador responsável: Márcia Fernandes Lourenço

Instituição: Faculdade de Educação da Universidade de São Paulo - FEUSP

Telefone: 011 98262-3767

E-mail: mfer@usp.br 
Este termo será preenchido em duas vias de igual teor, e uma será entregue a você.

Eu, PEÓnia brito de r." PEREIRA R.G. 0996027092 , como voluntário da pesquisa, afirmo que fui devidamente informado e esclarecido sobre a finalidade e objetivos desta pesquisa, bem como sobre a utilização das informações exclusivamente para fins científicos. Meu nome não será divulgado de forma nenhuma e terei a opção de retirar meu consentimento a qualquer momento.

São Paulo, 28 de Outubro de 2014.

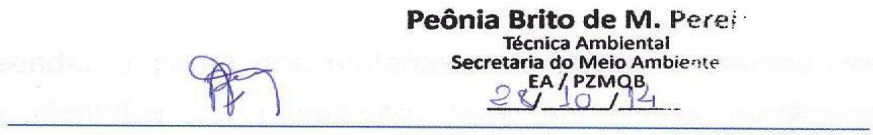

Participante da pesquisa

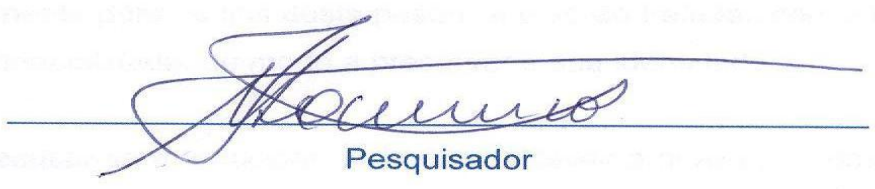




\section{TERMO DE CONSENTIMENTO LIVRE E ESCLARECIDO}

Prezada Pobenta Quarige Ilomez

Gostariamos de convidá-la a participar de uma pesquisa que será realizada na Faculdade de Educação da Universidade de São Paulo.

Sou pós-graduanda da referida universidade e estou cursando o doutorado em Ensino de Ciências.

Desde já quero agradecer a sua disponibilidade em ajudar no desenvolvimento dessa pesquisa. Sua colaboração é importante e necessária, porém sua participação é voluntária.

Para compreender o papel dos materiais educativos existentes em espaços na alfabetização científica da população, farei entrevistas semiestruturadas com gestores ou responsáveis pelos setores de comunicação das instituições que possuam esse material. As atividades serão gravadas, mas as informações serão utilizadas somente para os fins desta pesquisa e serão tratadas com o mais absoluto sigilo e confidencialidade, de modo a preservar a sua identidade.

Você pode recusar-se a participar, ou mesmo desistir a qualquer momento sem que isto acarrete qualquer ônus ou prejuizo à sua pessoa. E sendo um participante voluntário, você não terá nenhum pagamento e/ou despesa referente à sua participação no estudo.

Caso você tenha dúvidas ou necessite de maiores esclarecimentos pode me contatar.

Pesquisador responsável: Márcia Fernandes Lourenço

Instituição: Faculdade de Educação da Universidade de São Paulo - FEUSP

Telefone: 011 98262-3767

E-mail: mfer@usp.br 
Este termo será preenchido em duas vias de igual teor, e uma será entregue a você.

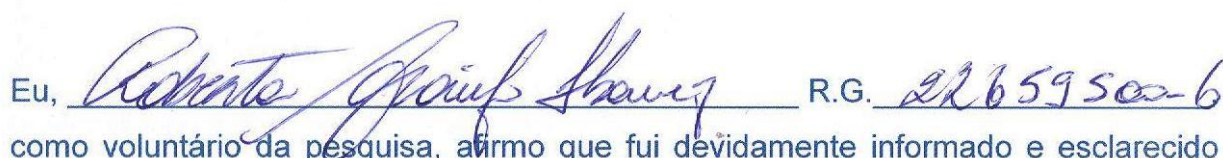
como voluntário da pesquisa, ahirmo que fui devidamente informado e esclarecido sobre a finalidade e objetivos desta pesquisa, bem como sobre a utilização das informações exclusivamente para fins científicos. Meu nome não será divulgado de forma nenhuma e terei a opção de retirar meu consentimento a qualquer momento.

São Paulo, 28 de Outubro de 2014.

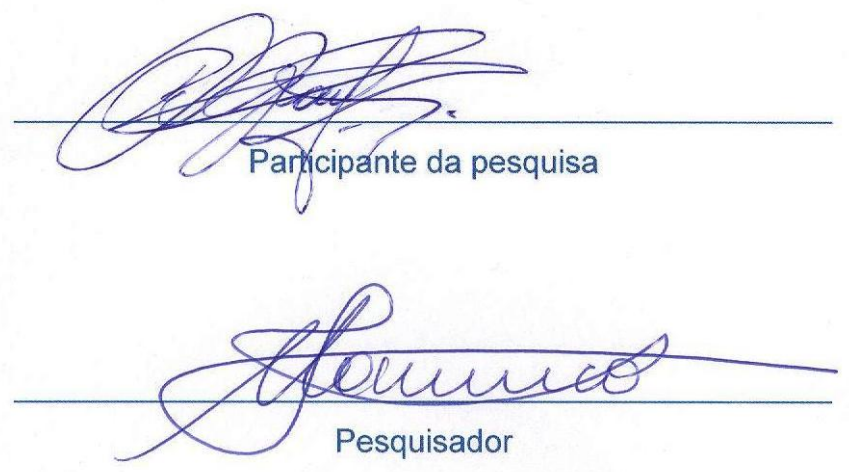




\section{TERMO DE CONSENTIMENTO LIVRE E ESCLARECIDO}

\section{Prezado Viviane Rachid Garcia,}

Gostariamos de convidá-lo a participar de uma pesquisa que será realizada na Faculdade de Educação da Universidade de São Paulo.

Sou pós-graduanda da referida universidade e estou cursando o doutorado em Ensino de Ciências.

Desde já quero agradecer a sua disponibilidade em ajudar no desenvolvimento dessa pesquisa. Sua colaboração é imporfante e necessária, porém sua participação é voluntária.

Para compreender o papel dos materiais educativos existentes em espaços na alfabetização científica da população, farei entrevistas semiestruturadas com gestores ou responsáveis pelos setores de comunicação das instituições que possuam esse material. As atividades serão gravadas, mas as informações serão utilizadas somente para os fins desta pesquisa e serão tratadas com o mais absoluto sigilo e confidencialidade, de modo a preservar a sua identidade.

Você pode recusar-se a participar, ou mesmo desistir a qualquer momento sem que isto acarrete qualquer ônus ou prejuizo à sua pessoa. E sendo um participante voluntário, você não terá nenhum pagamento e/ou despesa referente à sua participação no estudo.

Caso você tenha dúvidas ou necessite de maiores esclarecimentos pode me contatar.

Pesquisador responsável: Márcia Fernandes Lourenço

Instituição: Faculdade de Educação da Universidade de São Paulo - FEUSP

Telefone: 01156738161

E-mail: mfer@usp.br 
Este termo será preenchido em duas vias de igual teor, e uma será entregue a você.

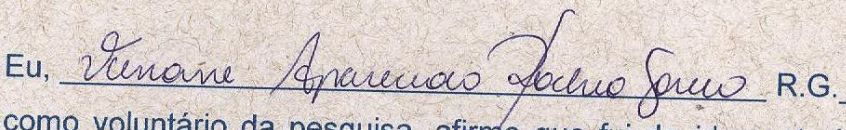
como voluntário da pesquisa, afirmo que fui devidamente informado e esclarecido sobre a finalidade e objetivos desta pesquisa, bem como sobre a utilização das informações exclusivamente para fins científicos. Meu nome não será divulgado de forma nenhuma e terei a opção de retirar meu consentimento a qualquer momento.

São Paulo, 17 de Outubro de 2014.
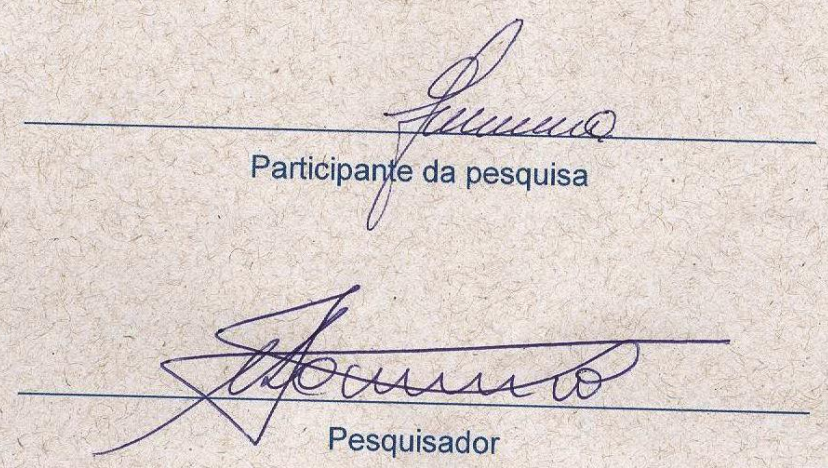